\title{
Knowledge-making Endeavours of the Dutch East India Company in Malabar, 1663-1795
}

\author{
Meera Gopurapillil Muralidharan
}

A thesis submitted to the Victoria University of Wellington in fulfilment of the requirements for the degree of Doctor of Philosophy in History.

Victoria University of Wellington 2021

Faculty of Graduate Research

January 2021 



\title{
Contents
}

\author{
Abstract \\ Acknowledgements \\ Abbreviations \\ Measurements and Currency \\ Glossary \\ Map \\ List of Maps and Figures \\ Abstract
}

Introduction

1. Trade, Culture and Polity in the Dutch Republic, 1600-1700

2. Fashioning Flora:

The Hortus Malabaricus and Indigenous Knowledge in Malabar, 1678-1693

3. Making Botany: The Hortus Malabaricus in the Republic, 1680-1775

4. Dutch Mapmaking: Visual creation of Power in Malabar, 1700-1795

5. From Pepper to Property: The Company Gardens in Malabar in the Eighteenth Century, 1750-95

Appendix I 


\section{Acknowledgements}

I have spent days imagining on how I would write my acknowledgement. But now that the task needs to be accomplished, I do not know if I can do justice to the people who have made this dissertation possible. I must start with my supervisor, Prof. Sekhar Bandyopadhyay, who I don't know how to thank enough for believing in me and guiding me through this journey every step of the way. His office has been my first stop to share any news, good or bad, related to my work and life in Wellington. I hope to achieve at least a fraction of what Bandyopadhyay has done for South Asian history. I was thrilled when my second supervisor, Associate Professor, James Beattie, joined the project in the second year; he has since been decisive in shaping my ideas into words. I hope to achieve the precision and detail with which Beattie approaches his work. I am thankful to both my supervisors for giving me the freedom to mould the thesis on my own. They have both instilled in me further discipline and passion for history. I could not have written this dissertation without the support of Emeritus Prof. Hugo s'Jacob. His knowledge and interest in Dutch history of Cochin are unmatchable. I spent a few but very enriching evenings in his house in Leiden discussing Dutch history where his wife, Nanda, offered me few cups of tea and food. I thank Dr Sebastian Joseph, the first person who noticed my passion for history and teaching and nurtured the interest ever since. He also gave me the opportunity to present my work at Kerala History Congress. The lectures on early modern science by Dr. Catherine Abou-Nemeh have enriched and inspired me to broaden my understanding of early modern European history. I am grateful to her for giving me the opportunity to deliver a guest lecture for her course in my second year and her comments on my seminars and presentations since then.

The History Centre at VUW has been my home for the past three and a half years (minus the time I spent away for data collection). As I always say, my office at the Old Kirk building is my first home, and my flat is my second home. I thank Teresa Durham for her fun conversations and help with various matters since my arrival. I thank Jonette Crysell, my other go to person, for helping me to straddle the way through the university bureaucracy and paper works. I would like to thank Justin Cargill, librarian, for checking on me and offering me lunches at Milk and Honey since my first year. Prof. Rohan D Souza whom I met in Brazil needs a special mention here because without him I would have been stuck in Brazil (a fine thread for a story). I have thoroughly 
enjoyed the conversations with History staff and postgraduate community at our History seminars since the time I joined Victoria. I thank Prof. Steve Behrendt and his wife Linda, for inviting me to their beautiful home for Christmas every year. I also thank Courtney Martin and Nayanthara for giving me the opportunity to deliver a guest lecture at the Centre for Science in Society, VUW.

If not for the constant support and cheerful faces of my $\mathrm{PhD}$ colleagues, I would have immersed myself in books and grief. I want to thank my dear friends, Edward (for his support since day one), Mark and his partner Catherine (without whose generous help I would be in deep trouble at one stage), Anton (my conference travel companion within and outside NZ), Nadya, Gillian (who checks on me every week) and Dean (for bringing me muffins and giving company in the History building in the weekends). These people have gone beyond their limits to make sure that I am well, and I can't thank them enough for their generosity in different capacities. I thank other postgraduates and colleagues, Sarah, Hayden, Sian, Will, Josh, Rachel, Ross and many others at Vic for interesting conversations. My two Bengali friends (I stress Bengali because I haven't followed half of their conversations), Sneha and Diya, sat with me in the final days of submission while I arranged my references and Bibliography. My few very special friends (more like family here), Gabi, Pavi, Abhi, a second Abhi (Chatterjee) and Jay helped me survive challenging days in Wellington. I love Anna-Marie for organising the much-needed writing boot camps where I did most of my writing and a whole lot of eating. I have enjoyed the company of Caitlyn, Jorge, Marian and Rana who made the writing boot camps exciting and fun. Nisha sent me a much-needed material from Auckland library in the final month of submission when Covid affected the arrival of library materials. I wish to remember the good wishes and encouraging words of Neeta Khandpekar from time and again.

I have benefitted from the many opportunities to present my work. I have presented parts of my thesis at different conferences, New Historians Conference (VUW), World Environmental History Conference (Brazil), Asia New Zealand Conference (2019), AAHPSS conference (2019), Encounters and Exchanges Conference (2019). I thank everyone who gave me feedback on these presentations. I thank PGSA for Research Excellence Award, Tutor Award Nomination) and other conference committees where I collected awards in November 2019 (that was one hell of a month) which played a significant role in boosting my confidence.

The staff at the libraries and archives in India and the Netherlands were crucial for getting me the sources for my work. I wholeheartedly thank Cherai Ramdas, whom I had the pleasure to meet in the Tamil Nadu Archives in Egmore for making sure that I received the Dutch records on time. I thank the team at the Government Guest House, Chennai for making me feel like home. Two of them, Gunapalam and Selvan, made futile attempts to teach me Tamil during my morning 
and evening teas in their staff room. My archival work in the Netherlands was possible only because of the generosity of some of my friends. Shahina and Musthafa, my family in the Netherlands since my University days in Leiden, hosted me for three months in the Netherlands. The time I spent with their kids, Ami and Adi were most cherishing. Shahina has been a constant source of inspiration and gave much needed counselling throughout my research. My other Leiden friends Aditya, Mou, Arun and Mahmood cheered me up with during my stay in the Netherlands. The teaching staff at Leiden University, Caroline Stolte, Nira Wickramasinghe and Rene Wezel have supported my academic ambitions since my student days at Leiden. They were generous enough to take time out to meet me while I was collecting data in the Leiden University library. Despite having trouble in accessing Dutch and early modern sources from New Zealand, my love for my time in Leiden, Hortus Malabaricus and anything and everything in South Asian history, history of science and colonial and decolonial histories persisted me to pursue this topic.

I am grateful for my friends in India, Akhil and Arun for listening to my rants now and then with patience and supporting me since my bachelor days in Kerala. Dr. Nisha whom I have never met in person sent me sources on Ayurveda.

Finally, I owe everything to my family in India. My mother, whose love knows no boundaries, my father who taught me to dream big and my lovely sister, Induja for cheering me always by sending me pictures and videos of my nephew, Shivank, who has brought so much joy into our lives amid COVID. My family has been my biggest strength and weakness at the same time. My PhD journey so far has been a roller-coaster ride caused by the emotional highs and lows in my personal life. Despite personal events that broke my spirits now and then, it is my love for Cochin, Leiden, Indo-Dutch history the work I do that has kept me going. I thank all the people who have supported in this journey and wished to see my $\mathrm{PhD}$ completion.

I dedicate this work to Padma Shri K. S Manilal who devoted his life to translate the twelve volumes of the Hortus Malabaricus from Latin to English and Malayalam. I hope to meet him one day. 


\section{Abbreviations}

ANRI Arsip Nasional Republik Indonesia (The National Archives of the Republic of Indonesia)

EIC English East India Company

KSA Kerala State Regional Archives, Ernakulam

$\mathrm{MvO} \quad$ Memorie van Overgave (Handover Memorandum)

NA Nationaal Archief (National Archives), The Hague

TSA Tamil Nadu State Archives (Chennai)

VEL Verzameling Buitenlandse Kaarten Leupe (Leupe Foreign Maps Collection)

(Nationaal Archief, The Hague)

VOC Verenigde Oost-Indische Compagnie (United East India Company)

WIC West-Indische Compagnie (West India Company) 


\section{Measurements and Currency}

Dutch (D), English (E), Malayalam (M)

\section{Measurements}

I parra

(M) Equals 40 lbs. Paddy measuring unit used in Kerala

\section{Currency $^{1}$}
1 Flemish pound
(D) Equals 6 guilders
1 Rixdollar
(D/ E) Equals 48 stuivers
1 Guilder
(D/ E) Equals 20 stuivers
1 Stuiver
(D) Equals 16 (penning)
1 Fanum
(D) Equals 10 stuivers

${ }^{1}$ Currency table prepared on the basis of the values referred to in Anjana Singh, Fort Cochin in Kerala, 1750-1830: The Social Condition of a Dutch Community in an Indian Milieu (Leiden: Brill, 2010), p.xvii. 


\section{Glossary}

Dutch (D), Portuguese (P), English (E), Malayalam (M), Hindi (H), Arabic (A)

Arrack $\quad$ (A) spirit made from molasses

$\begin{array}{ll}\text { Casado } & \text { (P) Portuguese settled in Asia }\end{array}$

Dagregisters $\quad$ (D) Daily Register

Ezhava $\quad$ (M) low caste group in the state of Kerala

Hakim $\quad(\mathrm{H})$ Muslim physician practising Unani medicinal tradition

Heren XVII $\quad$ (D) Directors of the VOC, also known as Gentlemen XVII

$\begin{array}{ll}\text { Hoge Regering } & \text { (D) High Government at Batavia consisting of the Governor General }\end{array}$ and the Council of Indies

Lascorijn / Lascar (E \& D) Person of indigenous origin in the service of European

Companies

$\begin{array}{ll}\text { Liefhebber } & \text { (D) Admirer or lover }\end{array}$

$\begin{array}{ll}\text { Mestiço } & \text { (P) People of mixed Portuguese and Indian descent }\end{array}$

$\begin{array}{ll}\text { Pagger } & \text { (D) hedge or fence outside a house made of bamboo or shrubs }\end{array}$

Rupees $\quad$ (E) Indian currency

Suri Juice from the coconut, also known as toddy

$\begin{array}{ll}\text { Stuiver } & \text { (D) Pre-decimal coin used in the Dutch Republic }\end{array}$

Toepas $\quad$ (P) Half-caste people of Portuguese descent who followed Roman

Catholicism

Vaidyam/ vaidyan $\quad$ (M) Medical practice (and practitioner)

Vrijburger $\quad$ (D) Europeans who lived in VOC settlements, not as the European servants but as 'free' person, also known as free-burghers 


\section{List of Maps}

1. Map of Malabar coast indicating the major Dutch settlements

2. VOC map of Company owned lands

3. VOC Map of Malabar Coast with Company lands, 1767

4. Map of Company lands

\section{List of Illustrations}

Fig. 1. Claes Jansz. Visscher's profile of Amsterdam, 1611

Fig 2. Jan Jansz. van de Velde III's painting, 'Still Life with Beer Glass'

Fig. 3. Girl Eating Oyster by Jan Havicksz

Fig. 4. Pepper plantation from Simon de Vries's travelogue, Curieuse aenmerckingen der bysonderste

Oost en West-Indische verwonderens-waerdige dingen, deel 1.

Fig. 5. The engraving of black pepper in Hortus Malabaricus

Fig. 6. Drawing of plant Illi from the Hortus Malabaricus

Fig. 7. Drawing of plant Adamaram from the Hortus Malabaricus

Fig. 8. Tenga (coconut tree), Hortus Indicus Malabaricus

Fig. 9. Leiden botanical garden

Fig. 10. Page from Jan Commelin, The Belgick, or Netherlandish hesperides

Fig. 11. Orangery in Leiden academic building

Fig. 12. Commissioned portrait of Jan Commelin by artist Gerard Hoet

Fig. 13. Images of pineapple illustrated in the Monickx Atlas

Fig. 14. Images of some plants referred by Commelin from the Hortus Malabaricus

Fig. 15. Images of pandi-pavel from the Hortus Malabaricus and the Hortus Medicus Amstelodamenis 
Fig. 16. Title page of Hortus Malabaricus

Fig. 17. Title page of Commelin's Hortus Amstelodamensis

Fig. 18. Plate showing coconut trees from the Hortus Malabaricus

Fig. 19. A plagiarised version of coconut trees in John Fryer's travel account.

Fig. 20. An illustration of kappa kelengu from Maria Sybilla's Metamorphosis

Fig. 21. Bird's eye view of Cannanore, 1665

Fig. 22. Portuguese plan of Cochin

Fig. 23. Dutch plan of Cochin, 1663

Fig. 24. The Dutch Stockade at Chettuwa

Fig. 25. Plan of the siege of Pappinivattom, 1766

Fig. 26. Plan for the reduction of the size of the fort, 1782

Fig. 27. Plan for the Cochin ship dockyard

Fig. 28. Copperplate engravings of coconut from the Hortus Malabaricus

Fig. 29. Page from Adriaan Moens's Memorandum 


\section{Map I}

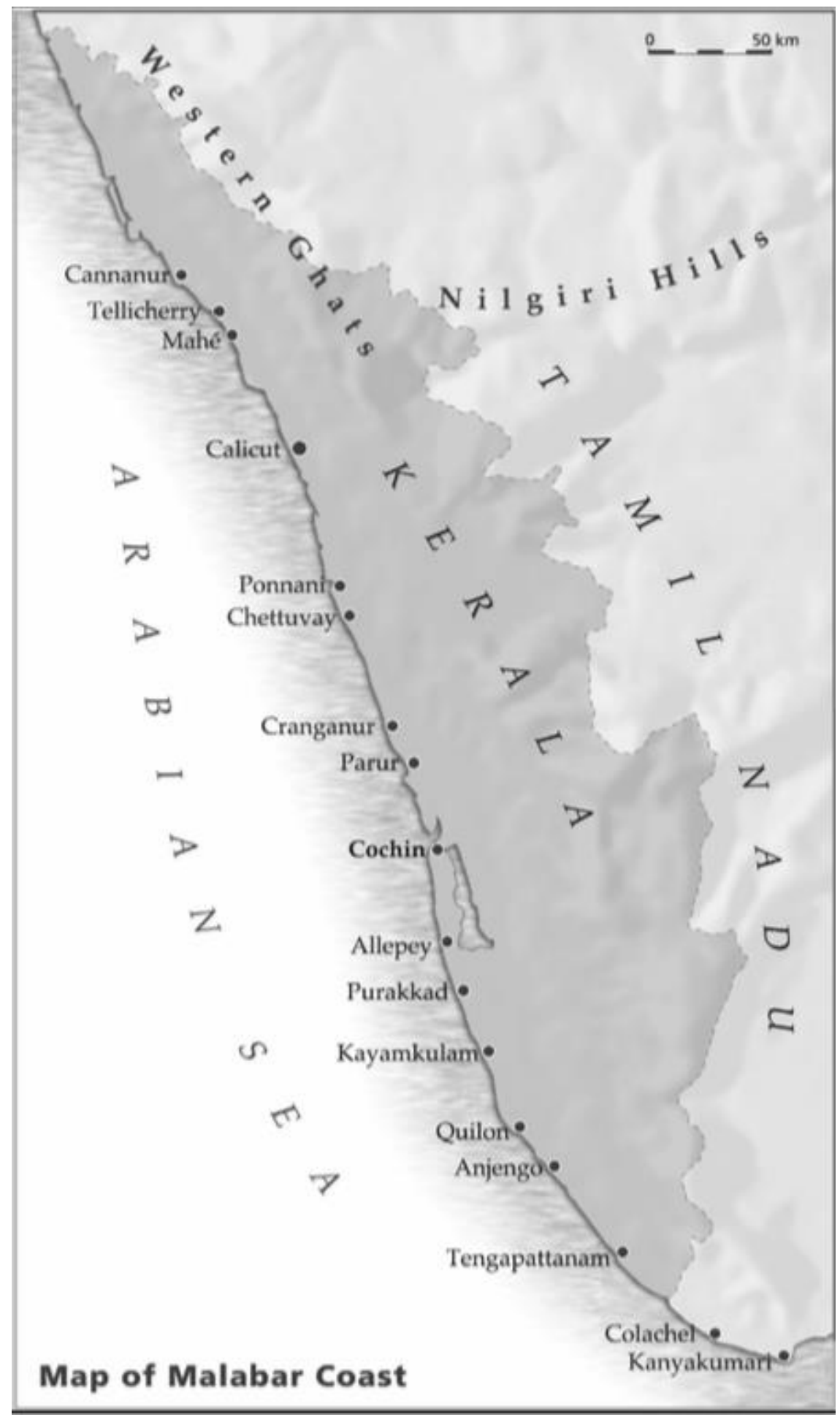

Map of Malabar Coast indicating the major Dutch settlements. ${ }^{2}$

2 Map reproduced from Anjana Singh, Anjana Singh, Fort Cochin in Kerala, 1750-1830: The Social Condition of a Dutch Community in an Indian Milieu (Leiden: Brill, 2010), p. 19. 


\begin{abstract}
The Malabar Coast of south-western India, presently comprising the modern state of Kerala, played a unique role in the history of Indian Ocean trade in the early modern period. Of the spices involved in expanding trade networks, the most important was pepper (Piper nigrum), indigenous to the region. Malabar's fame as a garden of spices (prompting European authors to call it the Pepper Coast) attracted ships from Europe, Africa, Arabia and East Asia. The Portuguese trading company, Estado da India, was the sole European enterprise that traded in Malabar in the fifteenth and sixteenth centuries. However, in the seventeenth century, the Dutch challenged Portugal's monopoly on trade. In 1663, the Dutch successfully captured the Portuguese settlements in Malabar including their major fort in Cochin. The Dutch remained in Malabar for the next hundred and thirty-two years after which the settlements passed to the English East India Company.

The primary motive behind European territorial expansion to Asia was not the production of knowledge; rather, trading networks required a detailed understanding of the natural world, especially its land, flora and fauna. By the late seventeenth century, the pursuit of knowledge, commerce and colonies, and a nascent patriotism were bound together. In this context, the present thesis examines the Dutch East India Company (Verenigde Oost-Indische Compagnie in Dutch) trade in Malabar. The thesis is set in the period between 1663 (when it first took over the territory from the Portuguese) and 1795 (when the Dutch possessions were usurped by the English East India Company). Two significant themes pursued in this context are how the VOC produced knowledge of the region, and how that knowledge-production relied heavily on patronage from the Dutch Republic as well as inputs from a variety of local actors in Malabar itself, as well as the Company's other territories. Nowhere can these themes be better explained than in the synergistic relationship of the sciences of botany and cartography.

The study analyses a variety of works produced about Malabar. This includes the Hortus Malabaricus, a seventeenth-century botanical work, which is analysed in the context of the development of botany in the Dutch Republic and early modern European trade in medicinal plants. Alongside natural history works, the study examines the VOC maps, topographical plans, and surveys of forts and gardens in Malabar to understand why the Dutch enterprise in Malabar failed in the eighteenth century. While scientific botany reflected the European need to master the natural world, the science of cartography reflected the need to govern it. In contrast to the Golden
\end{abstract}


image of the Republic (in the seventeenth century), arts and science were not effectively promoted by the Company administration. By re-examining and contextualising official and unofficial records of Dutch trading settlements in Asia, this thesis argues that contrary to dominant historiography, 'science' was not used as an effective tool by the Company in Malabar.

Using Susan Leigh Star and James R. Griesemer's theory of 'boundary objects', the chapters in the thesis address the heterogeneity in Company knowledge-production. The first half of the thesis focuses on botanical knowledge-production and the many actors involved in the making of early modern natural history works. The second half of the thesis examines geographical and bureaucratic knowledge-production and a significant shift in the Company policies from trade to land revenue in the second half of the eighteenth century. By historicising how knowledge was produced, the thesis attempts to understand if 'knowledge-making' was crucial for 'profit-making' in Malabar. This thesis thereby explores the intersectional character of early modern knowledgeproduction. 


\section{Introduction}

In May 2010, the Dutch artist and curator Renee Ridgway and filmmaker Van Amersfoort visited the birthplace of Kollat Itty Achuthan Vaidyan, Malabar physician referred to in Hortus Malabaricus, ${ }^{1}$ at Kadakkarappally, a small village about forty kilometres from Cochin, in Alappuzha District of Kerala, India. Accompanied by A. M. Arif, a member of Kerala Legislative Assembly, and Mr Chidambaran, Secretary of the Hortus Malabaricus Trust, the team documented the only remnants of the ancestral house and garden of the Vaidyan. The visit to pay homage stirred a renewed interest among the local villagers about their almost forgotten heritage, and it was widely reported in the local media. ${ }^{2}$

Why is a Dutch artist's visit to an ancestral house in a small village in Kerala significant today, when the Dutch presence in Malabar ended almost three hundred years ago? This thesis helps to answer that question, by examining Malabar's role in early modern history of science and Dutch imperialism. ${ }^{3}$ This thesis examines the knowledge-making endeavours of the Dutch East India Company (or Verenigde Oost-Indische Compagnie) ${ }^{4}$ in Malabar (present day state of Kerala) in the seventeenth and eighteenth centuries.

The Malabar Coast played a unique role in the history of Indian Ocean trade in the early modern period. The region is set apart from the rest of the peninsula by both its physiography and climate. Bound by the Indian Ocean on the west and the mountain ranges of the Western Ghats on the east, this region consists of evergreen and semi-evergreen tropical forests interspersed with well-watered alluvial valleys. The Malabar Coast acted as the primary locus of spice production. Of the spices involved in expanding trade networks, the most important was pepper (Piper nigrum),

\footnotetext{
1 The full title of the text is Hortus Indicus Malabaricus, Continents Regni Malabarici apud Indos celeberrimi omnis generis Plantas rariores (Latin) (1678-93). Referred to as the Hortus Malabaricus from here on, the English translation would be 'Garden of Malabar'. The Hortus Malabaricus is a seventeenth century work of botany on the plants in Malabar that was printed in twelve volumes in Amsterdam. Hendrik van Reede tot Drakenstein, Hortus Indicus Malabaricus, continens Regni malabarici apud Indos celeberrimi omnis generis plantas rariores, latinis, malabaricis, arabicis, \& bramanum characteribus nominibu(s)que expre(ss)as, una cum floribus, fructibus \&(s)eminibus, naturali magnitudine a periti(ss)imis pictoribus delineatas, \& ad vivium exhibitas..., 12 vols. (Amsterdam: 1678-1693).

2 'A historic Dutch visit to Kollat house'; https://hortusmalabaricus.net/historic-dutch-visit-kollat-house; accessed on 25 April 2020.

${ }^{3}$ In medieval accounts of travellers and merchants, 'Malabar' was used to denote a larger geographical space from Calicut to Goa. Malabar in this thesis represents the region with political boundaries of present-day state of Kerala.

${ }^{4}$ The Verenigde Oost-Indische Compagnie will be written as the VOC from here on.
} 
indigenous to the region. ${ }^{5}$ Malabar's fame as a garden of spices (prompting authors to call it the 'Pepper Coast') attracted ships from Europe, Africa, Arabia and East Asia.

Geographically, Malabar comprised areas belonging to the erstwhile kingdoms of Calicut, Cochin and Travancore, of which Fort Cochin was the seat of the VOC in Malabar. Cochin today includes the following geographical units: a) mainland Ernakulam and the three islands of Vypeen, Bolgatty and Willingdon, b) the former kingdom of Cochin, c) the town of Cochin that comprises the port, which was also the capital of the kingdom of Cochin. ${ }^{6}$ A significant shift in the historical development of the pepper trade involved the displacement of Chinese buyers by European buyers in the fifteenth and sixteenth centuries. The goal of dominating the pepper trade was one of the principal motives behind the expansionist endeavours of the Portuguese and later the Dutch and the English.

The Portuguese trading company, Estado da India, was the sole European enterprise that traded in Cochin in the fifteenth and sixteenth centuries. However, in the seventeenth century, the VOC challenged Portugal's monopoly on trade in Cochin. In 1663, the Dutch successfully captured the Portuguese settlements in Malabar, including their major fort in Cochin. The Dutch remained in Malabar for the next hundred and thirty-two years, after which the town passed into the hands of the English East India Company.

The primary motive behind European territorial expansion to Asia was not the production of knowledge about the lands, peoples, customs and environments. Rather, trading networks required a detailed understanding of the natural world, especially its land, flora and fauna. The trading alliances with local rulers in Asia required diplomacy, that was possible only with an intricate knowledge of laws, customs, geography, religious and social habits of the elites. By the late seventeenth century, the pursuit of knowledge, commerce and colonies, religious piety and a nascent patriotism were bound together. ${ }^{7}$ The networks of the British and the Dutch empires connected areas across continents and their rule shaped the environments in the regions that now lay within the boundaries of several nation-states. ${ }^{8}$

\footnotetext{
${ }^{5}$ Kathleen D. Morrison, 'Environmental History, Spice Trade, and the State in South India' in Mahesh Rangarajan and K. Sivaramakrishnan (eds.), India's Environmental History: from Ancient Times to the Colonial Period (New Delhi: Permanent Black, 2012), p.299.

${ }^{6}$ Pius Malekandathil, Portuguese Cochin and the Maritime Trade of India 1500-1663 (New Delhi: Manohar, 2001), p.22.

${ }^{7}$ Richard Drayton, 'Knowledge and Empire' in P. J. Marshall and Alaine Low (eds.), The Oxford History of the British Empire Vol II: The Eighteenth Century (New York: Oxford University Press, 1988), p.235.

${ }^{8}$ See the use of 'networks' model in Kerry Ward, Networks of Empire: Forced Migration in the Dutch East India Company (Cambridge: Cambridge University Press, 2008) and a slightly different version of 'web' model in Tony Ballantyne, Webs of Empire: Locating New Zealand's Colonial Past (Wellington: Bridget Williams Books, 2012). Ballantyne examines the British empire as a series of overlapping networks with circulations of imperial knowledge systems. These approaches have acknowledged the activities in the periphery which were otherwise absent in the colonizer-colonized tale.
} 
The European trade in Asia led to a string of trading networks across the globe with the aim of acquiring 'exotic commodities' and selling them in European markets. Networks of trade also fostered networks of knowledge-production, in the form of travelogues, law books and medico-botanical texts on the newly acquired territories. The collection of botanical knowledge formed a considerable part of the colonial endeavour. This catered both to the need for tropical medicines (to help maintain troops and traders operating in the tropics) and to explore the commercial possibilities of botanical products. The drugs procured from the New World and Asia were highly priced in the apothecary network in Europe. The trading companies also explored ways to cultivate these plants in Europe, and to supply other settlements in which slave labour was available, as in the case of Brazil.

The Dutch East India Company was by far the largest trading company active in the EuroAsian trade between 1600 and 1800. The pepper trade structured its operations in Asia. ${ }^{9}$ The Dutch administration in settlements in Malabar not only brought about changes in the ownership of lands, but its agents also tried to expand Dutch dominance over territories that were earlier not used for agriculture. The need for spices like pepper, cardamom, tobacco and other tropical crops induced Dutch authorities to enter into cordial relations with native rulers. Rulers who saw the monetary benefit arising from the foreign trade entered into political and economic agreements with the Company. European trade had a substantial impact on demarcating and redrawing of the spaces and borders of ruling kingdoms and their lands. The need to create administrative units was essential for the Company to manage its territories from afar. The printed Dutch maps from the seventeenth century 'picture an organized, rational, and planned global Dutch community during a period fraught with tensions at home and abroad'. ${ }^{10}$ Recent works on the survey of India during the eighteenth century have emphasized that the English East India Company relied on negotiations with locals and their surveying skills. ${ }^{11}$ This resulted in numerous drawings, plans of forts, settlements and topographical maps of Malabar settlements that represented a space that was claimed, organized and controlled. Knowledge, in the form of cartography, was therefore necessary to ensure successful domination over the newly acquired territories in Asia, and this was no less important in earlier periods, as this thesis demonstrates.

\footnotetext{
${ }^{9}$ Michael. R. Dove, 'The Political Ecology of Pepper in the Hikayat Banjar: The historiography of Commodity Production in a Bornean kingdom' in Peter Boomgaard, F. Colombijn and David Henley (eds.), Paper Landscapes: Explorations in the Environmental History of Indonesia (Leiden: KITLV Press, 1998), p.350.

${ }^{10}$ Elizabeth Sutton, 'Mapping Dutch Nationalism across the Atlantic', Artl@s Bulletin, Vol. 2, no. 1, 2013, p.13.

11 Kapil Raj, 'Ethnolinguistics and Cartography in Early Colonial India: Spaces of Circulation and Empires of Knowledge' in Paula Findlen (ed.), Empires of Knowledge: Scientific Networks in the Early Modern World (Oxford: Routledge, 2018), p.286.
} 
The Company maps were representations of the modes of thought in the Dutch Republic. They reflect the spatial arrangement of information, careful placing of forts and lands and present information as scientific knowledge. Cartography was an essential tool for facilitating trade and visually realizing the power over overseas colonies. ${ }^{12}$ In the case of Dutch maps, they acted as projections of their national character, as the Republic was shaping its own political identity in the seventeenth century. ${ }^{13}$ In the Republic, the Dutch navy's pursuits overseas triggered an increasing need for a workforce fluent in applied mathematics, including optics, surveying and navigation techniques. ${ }^{14}$ The newly emerging elites and merchants took part in this process of knowledgemaking and consumption of exotic goods. The materialism of early modern trade had a large following in the Republic.

The development of botany as a discipline in Dutch universities began in the 1500s resulting in the emergence of botanical gardens within the university premises. These new botanical gardens showcased new exotic plant species from Asia and the Americas. The increasing number of collectibles facilitated by overseas trade led to a new philosophy towards the objective analysis of nature. ${ }^{15}$ Botany thereby became the 'big science' and 'big business' in Europe. ${ }^{16}$ Historian Harold Cook argues that the beginnings of global science occurred during the period of the rise of global economy. ${ }^{17}$

In this context, the present study examines the Dutch East India Company trade in Malabar between 1663, when it first took over the territory from the Portuguese and 1795, when the Dutch possessions were usurped by the English East India Company. Two major themes pursued in this context are how the Dutch East India Company produced knowledge of the region and how that knowledge-production relied heavily on financial aid from the Republic, as well as inputs from a variety of local actors in Malabar as well as the Company's other settlements. These actors included local rulers and physicians, Dutch governors and the Board of Directors, as well as Company surgeons and engineers in Asia. Nowhere can these themes be better explained than in the synergistic relationship of the sciences of botany and cartography. Historians now assert

\footnotetext{
${ }^{12}$ Elizabeth Sutton, Capitalism and Cartography in the Dutch Golden Age (London and Chicago: The University of Chicago Press, 2015), p.1.

13 Ibid, pp.24-25.

${ }^{14}$ Catherine S. Abou-Nemeh, 'The Natural Philosopher and the Microscope: Nicolas Hartsoeker Unravels Nature's "Admirable CEconomy", History of Science, Vol. 51 no. 1, 2013, p.3.

15 Harold Cook, Matters of Exchange: Commerce, Medicine and Science in the Dutch Golden Age (New Haven and London: Yale University Press, 2007), p.304.

${ }^{16}$ See, Londa Schiebinger, Plants and Empire: Colonial Bioprospecting in the Atlantic World (Cambridge, Massachusetts: Harvard University Press, 2004), p.5.

${ }_{17}$ Cook, Matters of Exchange, p.416.
} 
that modern sciences originated through colonial contact. ${ }^{18}$ This thesis argues that there is not just one form of knowledge, i.e., Western science, but a variety of knowledge traditions. Historians have acknowledged that science (in the general sense of systematic knowledge) was never uniquely Western but developed in different forms in a wide variety of cultures, both ancient and modern, including Islam, India and China, the Americas, Africa and the Pacific. ${ }^{19}$

The main objective of this study is to enquire into the knowledge-making endeavours of the VOC in Malabar. This study thereby places itself within the historiography of colonialism that attempts to argue that materiality, maritime networks and knowledge-production were essential for European colonial expansion. The theme of knowledge-making, central to the thesis, refers specifically to the activity that leads to an increased understanding of natural history. This is not to oversimplify what knowledge-making entails. In the early modern period, art and science were inextricably related to the production of knowledge as the arts influenced the investigation of nature. In early modern Europe, art or ars possessed a broader 'meaning of practice and experience and was used in the case of mechanical arts to refer to the work of human hand'. ${ }^{20}$ Producers of natural knowledge, such as the physicians, cartographers and naturalists discussed in this thesis, were seen as producing art. Science or scientia, on the other hand, meant theoretical knowledge that could be ascertained with certainty by deductive means. ${ }^{21}$ This thesis will attempt to highlight the limitations of ars/scientia categories when understanding early modern science beyond Europe. As this thesis will proceed to show, colonial science can fall short of acknowledging different producers of knowledge with its Euro-centric understanding of science. The production of knowledge in the regions to which Europeans travelled for trade meant an exposure to nature that they were unaccustomed to. This meant that the producers of knowledge were not only artists and naturalists but also Company officials, surveyors and locals who surveyed and documented information about lands, peoples and their environments. Historian of science Lorraine Daston argues that science is only one distinct species of the genus of knowledge, it is not the only one. Another species might be "the complex "bureaucratic knowledge" that entails collections of record-keeping, classifying, controlling and labor-dividing practices'. ${ }^{22}$ This thesis will probe

\footnotetext{
${ }^{18}$ Londa Schiebinger defines colonial science as: 'any science done during the colonial era that involved Europeans working in a colonial context. This includes science done in Europe that drew on colonial resources in addition to science done in areas that were part of Europe's trading or territorial empires'. See, Londa Schiebinger, 'Forum Introduction: The European Colonial Science Complex,' Isis, Vol. 96, 2005, p.52.

${ }^{19}$ David Turnbull, Masons, Tricksters and Cartographers: Comparative Studies in the Sociology of Scientific and Indigenous Knowledge (London: CRC Press LLC, 2000), p.6.

${ }^{20}$ Pamela Smith, 'Art, Science and Visual Culture in Early Modern Europe', Isis, Vol. 97, no. 1, 2006, p. 84.

${ }^{21}$ Ibid, pp. 84-85.

${ }^{22}$ Lorraine Daston, 'The History of Science and the History of Knowledge', KNOW: A Journal on the Formation of Knowledge, Vol. 1, No. 1, 2017, p. 146.
} 
knowledge-production by widening the scope of knowledge to include botanical, cartographical and bureaucratic knowledge that the VOC produced in Malabar in the seventeenth and eighteenth centuries. To analyse knowledge-production outside Europe, this thesis takes a global approach in exploring multiple linguistic and cultural sites of early modern commerce. In the case of colonial centres like Malabar, the nature of 'knowledge-making' is uniquely local. This means the knowledge that was produced was shaped by the interactions with local experts who were indispensable in the knowledge-making process. By taking the VOC-Malabar trade as the backdrop, this thesis tries to broaden the dynamics of understanding early modern science through understanding local actors as producers of science (see Chapter Three for various Malabar medicinal systems that were seen as science and not as ars as in Europe). By broadening the categories, spaces and actors, this thesis on the VOC knowledge-making endeavours in Malabar tries to engage with commerce and knowledge-production in a colonial trading centre. In doing so, the thesis tries to widen the scope of early modern science by studying natural knowledge in local spaces and the processes by which it is assimilated to metropolitan centres. This assimilation of knowledge which is categorised as 'colonial science' was not the product of either a colony or metropole but a rather complex process in which natural knowledge was understood, investigated and pursued, fuelled by colonial ambitions. The thesis will try to analyse the motives behind such enquiry and investigation of nature shaped by European commerce and territorial expansion.

The present study will focus on the actors, places, media, and power relations involved in the networks of knowledge-production that developed in early modern Malabar and the Dutch Republic. Pamela Smith has argued that 'we cannot write a more global history of science in the age of the Scientific Revolution without considering the Dutch as some of the premier knowledge brokers of the seventeenth century'. ${ }^{23}$ By taking the Dutch trading company as a central force, this study however argues that without adequate patronage for scientific endeavours, knowledgemaking was only a peripheral activity for the Dutch East India Company. To examine early modern knowledge-production, it draws from recent literature and frameworks of circulations of knowledge, knowledge-networks, knowledge exchanges, polycentric sites of knowledgeproduction. The frameworks of the contact zone (popularized by Mary Louis Pratt in colonial interactions) ${ }^{24}$ and circulation of knowledge (used by Kapil Raj), ${ }^{25}$ taken together, can link the occurrences at a local level with global networks, where sites like Malabar play an active role. In

\footnotetext{
${ }^{23}$ Pamela Smith, 'A Tulip for a Cup of Tea? Commerce and Nature in the Dutch Golden Age', Annals of Science, Vol. 66, no. 2, 2009, p.269.

${ }^{24}$ See, Mary Louis Pratt, Imperial Eyes: Travel Writing and Transculturation (London and New York: Routledge, 1992), p.4.

${ }^{25}$ See, Kapil Raj, Relocating Modern Science: Circulation and the Construction of Knowledge in South Asia and Europe, 1650-1900 (London: Palgrave Macmillan, 2007), p.274.
} 
Raj's writings, circulation means circulation of knowledge: an analysis of the processes of encounter, negotiation, and reconfiguration of knowledge that occur in cross- cultural interaction, but one that is sensitive to the asymmetries of power in such processes and the resistances that might ensue. Pratt describes contact zones as spaces where disparate cultures meet, clash and grapple with each other in highly asymmetrical relations of domination and subordination. While all these theoretical formulations are significant and welcome, they fail to acknowledge the intricate complexities of power, status, patronage in the knowledge-making endeavours.

Apart from individual endeavours, the Company did not invest financially in producing botanical or geographical knowledge unless it was 'useful knowledge' for the Company. Information regarding potential trading routes, navigational and surveillance information were prioritized over the natural history of the settlements. By taking the case study of the Company activities in Malabar (1663-1795), the study opens newer ways of looking at the functioning of early European companies in Asia. By looking at the trade, botanical, cartographical and empire building efforts in Malabar, this study argues that knowledge was valued as an aid in the territorial, political and economic expansion of the Company in Malabar if it could promise immediate material benefits. However, in most cases the knowledge enterprises failed as they did not get receive financial support from the Republic.

Imperial science is acknowledged as a tool of empire building. But in the Dutch Republic at the beginning of the eighteenth century, not all scientific projects were encouraged or funded. Contrary to the Golden Age of the Republic (in the seventeenth century), arts, culture and science were not effectively promoted by Company administration in its overseas territories. By historicizing the ways in which knowledge was produced, this thesis attempts to understand if 'knowledge-making' was crucial for 'profit-making' in Malabar. In other words, to what extent did botanical and geographical knowledge dictate the Company's activities in Malabar?

\section{Literature Review}

The intricate relationship between European expansion in Asia and knowledge-production has garnered increasing scholarly attention in the last two decades. This study has benefitted from diverse thematic frameworks from histories of early modern trade, environment and science. This thesis brings together previously disparate studies of trade history, environmental history, and history of science.

The field of early modern science in South Asia has developed from a focus on trade histories to one of histories of science and environment. Economic and political historians have 
produced some of the prominent works on early European trading companies in Malabar. Ashin Das Gupta pioneered work on Malabar trade using the Dutch archives in $1967 .{ }^{26}$ His Malabar in Asian trade argued that by the year 1740, Malabar was in crisis with a decline in the spice trade. Before the regional histories of the European spice trade was written, few scholars examined maritime histories in a longue durée. Michael Pearson's works on the Indian Ocean have highlighted the importance of reversing the analytical gaze from sea to the shores, to examine the movement of ideas, goods and people across the Indian Ocean that shaped the histories and cultures of coast lines. ${ }^{27}$ Though earlier studies have focused on the European spice trade, recent work on Malabar's pepper trade by Sebastian Prange focussed on Muslim trading communities such as the Karimi merchants. ${ }^{28} \mathrm{He}$ argued that a restructuring of pepper trade networks occurred around the Indian Ocean in the sixteenth century with the coming of the Portuguese to the Malabar Coast. ${ }^{29}$ These works on the early trading networks in the Indian Ocean provide the context for the present study.

In contrast, Kerala historians have for a long time been concerned with the 'epochal' arrival of Vasco De Gama in Calicut. ${ }^{30}$ In their works, the Portuguese and Dutch trading histories were treated as brief interregnums before the long British domination in the region. ${ }^{31}$ On the Portuguese pepper trade in Malabar, the works of Pius Malekandathil are significant for highlighting some of the non-European actors involved in the spice trade in Malabar. With the use of extensive Portuguese materials, Malekandathil identified the major Christian and Muslim mercantile groups in Cochin that controlled the spice trade, such as Konkanis, Marakkars and Mappilas. ${ }^{32}$ Malekandathil argues that the increase in production, under Portuguese rule, was realized through

\footnotetext{
${ }^{26}$ Ashin Das Gupta, Malabar in Asian Trade: 1740-1800 (London and New York: Cambridge University Press, 1967), p.2.

${ }^{27}$ See Michael. N. Pearson, The Indian Ocean (London: Routledge, 2003) and for an analysis of spice trade, see, Michael. N. Pearson, Spices in the Indian Ocean World (London: Ashgate Publishing, 1996).

${ }^{28}$ Sebastian Prange, Monsoon Islam: Trade and Faith on the Medieval Malabar Coast (Cambridge: Cambridge University Press, 2018).

${ }^{29}$ Sebastian Prange, "Measuring by the bushel”: Reweighing the Indian Ocean pepper trade', Historical Research, Vol. 84, no. 224, 2011, pp.212-235.

30 C. R. Boxer, The Portuguese Seaborne Empire 1415-1825 (New York: A. A. Knopf, 1969) and C. R. Boxer, The Dutch Seaborne Empire 1600-1800 (London: Penguin, 1990, Reprint).

31 Sreedhara Menon, A Survey of Kerala History (Kottayam: Sahitya Pravarthaka Co-operative Society Ltd., 1967), 20913; K. M. Panikker, Malabar and the Dutch (Bombay: D.B. Taraporevala Sons and Co, 1931). Most of the studies of Kerala history used 'late medieval' to denote the period before the British rule of the region.

32 Pius Malekandathil, Portuguese Cochin and the Maritime Trade of India 1500-1663 (New Delhi: Manohar, 2001). By focusing on the trading communities, Malekandathil argues that despite the Portuguese intrusion into Malabar spice trade, local merchants were not replaced, as many of them entered new commercial alliances with the Portuguese. Malekandathil also points to a new inland route via the Western Ghats for exporting spices from the hinterlands of central Kerala to other neighbouring ports and towns. For instance, see Pius Malekandathil, 'Winds of Change and Links of Continuity: A study on the Merchant Groups of Kerala and the Channels of their Trade, 1000-1800', Journal of the Economic and Social History of the Orient, Vol. 50, 2007, pp.259-286.
} 
the organized extension of spice cultivation to wider regions, but his work does not specify the areas to where the production was expanded. ${ }^{33}$ Another significant work on early modern mercantile communities was undertaken jointly by Sanjay Subrahmanyam and Christopher Bayly. ${ }^{34}$ There were many sub-groups in the period from the sixteenth to the nineteenth century in South Asia which were lumped together in the broad category of 'merchants'. Subrahmanyam and Bayly argued that these sub-groups, identified as 'portfolio capitalists', need to be distinctively identified to understand how they straddled the worlds of commerce and politics simultaneously. This analysis holds significance for early modern trading networks in Asia. The present study has attempted to examine some of the non-Dutch merchants in Malabar trade and their 'middlemen' activities in Malabar (see Chapter 5).

Though the Dutch East India Company has received attention in European historiography, very little has been written on the Dutch settlements in seventeenth- and eighteenth-century South Asia. ${ }^{35}$ Since the 2000s, several works using Dutch archival sources have been published in Leiden, among which is Anjana Singh's prominent work, Fort Cochin in Kerala, 1750-1830. ${ }^{36}$ Singh's work is the only comprehensive study of the social life of the Dutch community in Cochin. Singh argues that Cochin, despite being a major trading region for the Dutch, has been left out of the literature. ${ }^{37}$ Her comments, made a decade ago now, still ring true. The literature on trade and early Company activities highlights a significant issue: the role of the Dutch Company in Malabar is reduced to commercial ventures only. The Company historiography of the seventeenth century is often told as a tale of glory when the trade was dominated by the

\footnotetext{
33 Pius Malekandathil, 'Agrarian Production and Procurement Strategies in Kerala', Pius Malekdanthil (ed.), Portuguese Cochin and the Maritime Trade of India 1500-1663 (New Delhi: Manohar, 2001), pp.22-23. Malekandathil primarily draws his sources from an earlier Polish scholar, Jan Keiniewicz who mapped some of the pepper gardens that existed in central Malabar. See, Jan Kieniewicz, 'Asian Merchants and European Expansion: Malabar Pepper Trade Routes in the Indian Ocean World-System in the Sixteenth Century' in K. R. Haellquist (ed.), Asian Trade Routes: Continental and Maritime (London: Curzon Press, 1991), pp.78-86.

${ }^{34}$ Sanjay Subrahmanyam and Christopher Bayly, 'Portfolio Capitalists and Political Economy of Early Modern India', The Indian Economic and Social History Review, Vol. 25, 1988, pp.243-265. As far as the existing literature on Southern Indian political economy is concerned, it has focused on the rice cultivation and Brahmin settlements of early medieval period.

35 Femme S. Gaastra, The Dutch East India Company: Expansion and Decline (Zutphen: Walburg Pers, 2003); George D. Winius and Marcus P. M. Vink (eds.), The Merchant-Warrior Pacified: The Dutch East India Company and its Changing Political Economy in India (Delhi: Oxford University Press, 1994) and Jonathan Israel, Dutch Primacy in World Trade, 1585-1740 (Oxford: Clarendon Press, 1989).

36 Anjana Singh, Fort Cochin in Kerala, 1750-1830: The Social Condition of a Dutch Community in an Indian Milieu (Leiden: Brill, 2010); Hugo K. s'Jacob, The Rajas of Cochin 1663-1720: Kings, Chiefs and the Dutch East India Company (New Delhi: Munshiram Manoharlal, 2000) for a detailed study of Dutch political relations with the rulers of Cochin. On the Cannanore Dutch settlement, see, Binu J. Mailaparambil, Lords of the Sea: The Ali Rajas of Cannanore and the Political Economy of Malabar (1663-1723) (Leiden: Brill, 2012).

37 See, Singh, Fort Cochin in Kerala, pp.55-62.
} 
Dutch in the Indian Ocean. This glory began to fade in the eighteenth century. A case study of the Company in Malabar shows that the picture from the official records of European companies often contradicted the reality on the ground. The proposals often made by the officials in the settlements were not implemented by the Company Directors, especially when it came to nontrade activities such as assessing land revenues, developing fortifications or plantations, and the like.

In South Asia, well before the 'scientific turn' in historiography, as evident from the literature in the last decade, ${ }^{38}$ there has been a growing interest in understanding the colonial policies that shaped the environmental governance of the overseas territories of European colonizing powers. The prominent historian who has taken this view is Richard Grove. His works stimulated a slew of environmental history writings in South Asia and Africa, and significantly contradicted some of the arguments by South Asian historians that colonial rule was solely responsible for the destruction of the environment in the colonies. ${ }^{39}$ Grove's writings connected European expansion and penetration of capitalist economic forces to its transformative influence on the tropical environments. Grove argued that the early conservationist approaches to the environment arose not in the 1990s, but as early as the arrival of European trading groups in Asia and Africa. In his ground-breaking work, Green Imperialism, Grove conceptualised the oceanic island 'Eden' that transcended imperial boundaries. ${ }^{40}$ Using expansive archival materials of private

${ }^{38}$ Dhruv Raina and Irfan S. Habib, Domesticating Modern Science: A Social History of Science and Culture in Colonial India (New Delhi: Tulika Books, 2004) and Raj, Relocating Modern Science.

39 South Asian environmental history arose with a growing concern for the depletion of forest covers and climatic changes. For instance, books were published after the surge of environmental movements such as the Chipko Movement of the 1970s, see, Ramachandra Guha, The Unquiet Woods: Ecological change and Peasant Resistance in the Himayala (Berkeley: University of California Press, 1990). Guha traced the pre-history of the conflicts between forest people (adivasis) and state over water and land in the Narmada Valley. Guha noted in the preface that historians have neglected the relationship between colonialism and environmental decline. Guha pioneered two foundational texts of South Asian environmental history. In 1992, Guha co-authored with ecologist Madhav Gadgil and Ramachandra Guha (eds.), This Fissured Land: An Ecological History of India (New Delhi: Oxford University Press, 1992). This work is one of the earliest attempts to write a general environmental history of the subcontinent. Though the work looms large over the questions of contests over the forests, it inspired researchers to view South Asian history from an ecological point of view. Another collection of essays by David Arnold and Ramachandra Guha (eds.), Nature, Culture and Imperialism: Essays on the Environmental History of South Asia (New Delhi: Oxford University Press, 1995) where they throws light on the distinctiveness of South Asian ecology by broadening the scope of environmental history beyond forests to pastoralism, irrigation, fisheries and more. Scholars in this book argue that research needs to be widened to studies of water bodies and forests to examine their role in shaping the environmental history of the subcontinent. The book concludes by raising some serious concerns about the literature gap that exists in South Asian historiography when compared to the expansive literature on environment in the US and France. These two works not only paved the way for more research in South Asian ecology but also provided theoretical models for approaching environmental history and British colonialism in South Asia. While the works shifted the focus from colonialism, they were mainly on modern South Asia.

${ }^{40}$ Richard Grove, Green Imperialism: Colonial Expansion, Tropical Island Edens and the Origins of Environmentalism 1600-1860 (Cambridge: Cambridge University Press, 1996). Among the islands discussed in the book are St. Helena, Ascension, 
letters of surgeons, botanists and scientists who worked for the English East India Company (EIC), Grove gave an alternative view of the imperial bureaucracy by retrieving voices wanting a 'greener world'. Grove examined the perceptions of environmental change that resulted in concerns over economic development and human health. But as environmental historian Mahesh Rangarajan has noted, Grove's arguments underplayed the impact of colonial rule that displaced older systems of resource use and renewal. ${ }^{41}$ Nevertheless, in response to Grove's arguments, a considerable historical literature developed in the last two decades by environmental and climate historians. ${ }^{42}$ Modifying Grove's argument, for example, James Beattie subsequently argued that 'environmental anxiety' prompted efforts to jointly conserve and develop colonial environments. ${ }^{43}$

In partial fulfilment of Grove's vision for global environmental history, the edited volume, The East India Company and the Natural World, placed English East India Company rule and its impact on the environment in a global perspective. ${ }^{44}$ Essays in this work argued for a nuanced understanding of the colonial administration and changing environment in a global context between 1600 and 1857. Vinita Damodaran supported Grove's argument that the East India Company found 'conservationism to its taste and economic advantage', giving rise to early ideas of environmentalism. ${ }^{45}$ For the present thesis also, Grove's works have been more useful for examining the literature on Company gardens in the Cape and his discussion of the Hortus Malabaricus; though this study differs from Grove's final arguments on the use of indigenous knowledge in south-west India (see Chapter 2). ${ }^{46}$

In contrast to scholarship on the English East India Company (and later British Raj), and apart from Peter Boomgaard's works, very scant literature is available on the environmental history of Dutch settlements in Southeast Asia. Boomgaard's co-edited collection of essays, Paper

and Mauritius on the sea route to India, and Tobago and St. Vincent in the eastern Caribbean. In addition, Grove gives attention to India and to the Cape area in South Africa. The Pacific is less central to his narrative, although he mentions the impression made on his central figures by Tahiti and several of the other islands of the largest ocean. Grove used archival documents that exhibited concerns for denudation of lands and grave climatic changes in the absence of colonial government regulations on forests. In search of a lost paradise or Eden, Grove argues that many scientists were alarmed at the changing environment of the oceanic islands that gave a clear picture of the many processes of deforestation, extinctions, desiccating climate, shortages of essential resources, disease, and famine.

${ }^{41}$ Mahesh Rangarajan, 'Crusoe Along', The Telegraph, 10 November 1995, p.2.

42 Ruth A. Morgan, 'Histories for an Uncertain Future: Environmental History and Climate Change,' Australian Historical Studies, Vol. 44, no. 3, 2013, pp: 350-360; Brett M. Bennett, 'Environmental Conservation and Deforestation in India 1855-1947: A Reconsideration', Itinerario: International Journal of the History of European Expansion and Global Interaction, Vol. 38, no. 2, 2008, pp.93-104.

${ }^{43}$ James Beattie, Empire and Environmental Anxiety: Health, Science, Art and Conservation in South Asia and Australasia (Basingstoke: Palgrave Macmillan, 2011), p.1.

${ }^{4}$ Vinita Damodaran, Anna Winterbottom and Alan Lester (eds.), The East India Company and the Natural World (London: Palgrave Macmillan, 2015). The work is a collection of essays that widely looks at the environment history of the erstwhile colonies like India, South East Asia and New Zealand.

${ }^{45}$ Vinita Damodaran, 'Afterword' in East India Company, pp. 270-271.

${ }^{46}$ Grove, Green Imperialism, pp.84-90. 
Landscapes, opened the field of the environmental history of Indonesia, the erstwhile Dutch colony. ${ }^{47}$ Despite having such a long history of European trade and colonial legacy, the first work on the environmental history of Cochin was published only in 2016. In Cochin Forests and the TechnoEcological Imperialism in India, Kerala historian Sebastian Joseph focused on the tramway, introduced in 1907 by the British in the princely state of Cochin to transport timber from the dense forests of Cochin to the port. ${ }^{48} \mathrm{He}$ argued that the British forest policies proved to be an economic and ecological disaster for Cochin leading to a depletion of forest cover in the region. What is entirely missing in Joseph's work is any pre-engagement with pre-British Cochin, thereby missing the longue durée ecological picture of the region. Though this study has benefitted from the arguments of the environmental history works, it is placed within the framework of the history of science as it aids in fully exploring the research questions.

Since the publication of Bruno Latour's work, Science in Action (1987), ${ }^{49}$ a new genre of scholarship focussing on 'networks' has emerged across disciplines. Most works on early modern knowledge-production have used versions of this analytical framework. Nowhere is the idea of interconnectedness of networks of science, commerce and medicine of the Dutch Republic better articulated than in the works of Harold Cook. In a detailed study of medicine and science, Cook argued that modern science could only emerge under the unique conditions of global trade as it converged in the highly cosmopolitan Dutch Republic of the seventeenth century. Cook demonstrates that wisdom (sapientia) and trade (mercatura) were closely intertwined activities that sprang from the same mental category. ${ }^{50}$ While Jonathan Israel focussed on the humanist ideas (of Grotius, Spinoza, Rembrandt, Vermeer) that emerged from the Republic, Cook argued that commercial enterprises were the key factor in the Scientific Revolution. ${ }^{51}$ Cook's works have inspired this study to look at knowledge-making endeavours in Malabar and the Dutch Republic in the context of trade and commerce in the seventeenth century.

The more prominent theme that has benefitted from these historiographical debates is the study of natural history, mainly medico-botanical knowledge-production. An edited volume by

\footnotetext{
${ }^{47}$ Peter Boomgaard, F. Colombijn and David Henley (eds.), Paper Landscapes: Explorations in the Environmental History of Indonesia (Leiden: KITLV Press, 1998). In the Introduction, Boomgaard claims that three themes lend coherence to the volume: attention to the issue of sustainability, to the importance of natural risks and hazards, and of long-term perspectives. Though these themes do not repeatedly surface throughout the book, the value of the book cannot be underestimated as it is the only major text on the environmental history of the Indonesian archipelago; Peter Boomgaard, Southeast Asia: An Environmental History (Santa Barbara: ABC-CLIO, 2007).

${ }^{48}$ Sebastian Joseph, Cocbin Forests and the Techno-Ecological Imperialism in India (New Delhi: Primus Books, 2016).

${ }^{49}$ Bruno Latour, Science in Action: How to follow scientists and engineers through Society (Cambridge and Massachusetts: Harvard University Press, 1987).

${ }^{50}$ Harold Cook, Matters of Exchange, p.69.

${ }^{51}$ Jonathan Irvine Israel, The Dutch Republic: Its Rise, Greatness and Fall, 1477-1806 (Oxford: Clarendon Press, 1995).
} 
Londa Schiebinger and Claudia Swan sheds light on the nexus between botanical science, commerce and state politics in early modern Europe. In their introduction, they argue that the development of botany has to be examined alongside Europe's commercial and territorial expansion. ${ }^{52}$ For this thesis Swan's work on the origins of the Leiden botanical garden has proved useful for contextualising the trading of tropical plants (see Chapter 3). The expanding science of plants depended on European access to ever farther-flung regions of the globe; at the same time, colonial profits depended largely on identification of commercial plants and their effective largescale cultivation in the settlements. Schiebinger's 'bio-prospecting' framework allows one to see the official involvement in the search for medicinal plants in the areas into which the European companies expanded. ${ }^{53}$ While some scholars have focussed on the relationship between science and commerce in Europe, some have looked beyond Europe to see how knowledge networks operated across cultures.

An example is Anna Winterbottom's work, Hybrid Knowledge in the Early East India Company World. Winterbottom draws a contrast between the metaphors of 'co-production' and 'circulation', and argues that 'hybrid knowledge' better conveys 'the possibility of translating knowledge across cultures but also the clashes and disconnections involved in knowledge networks composed of communities whose interactions can be better classed as "contained conflict" rather than as "partnership". ${ }^{54}$ This thesis does not fully agree with the theme of contained conflict in knowledge-making as knowledge-production did not always include conflict but a collaboration though unequal in nature in terms of power distribution. The producers of knowledge often belonged to various economic and social classes and castes in Malabar. As a result, knowledgeproduction was often hierarchical in nature. As this thesis will show, not all producers of knowledge were given credit for their labour in producing knowledge of the region. In a close analysis of the relationship between the Royal Society in London and the English trading Company in the seventeenth and eighteenth centuries, Winterbottom eloquently highlights the need for patronage for the trading companies. Patronage came in terms of both financial support for scientific endeavours or as occupational mobility as this thesis would proceed to show in the case of the VOC officials in the Indies. She argues that the knowledge produced was 'useful knowledge' rather than just scientific knowledge. The company officers were only supported in their knowledge pursuits if it resulted in any economic advantage for the expansion. In my view,

\footnotetext{
${ }^{52}$ Londa Schiebinger and Claudia Swan, Colonial Botany: Science, Commerce and Politics in the Early Modern World (Philadelphia: University of Pennsylvania Press, 2005), p.3.

${ }^{53}$ Schiebinger uses the term 'bioprospecting' to describe the attempts made by the European trading companies in collecting and compiling medico-botanical knowledge in the Atlantic world. Schiebinger, Plants and Empire.

${ }^{54}$ Anna Winterbottom. Hybrid Knowledge in the Early East India Company World (Cambridge and New York: Palgrave Macmillan, 2015), pp. 2-3.
} 
Daston's 'bureaucratic knowledge' was more similar to the useful knowledge that Winterbottom describes. Both savant institutions like the Royal Society, and the trading companies, she shows, strove to prove their usefulness throughout this period. The knowledge-making meant trading companies had to please multiple constituents, such as European and non-European rulers, their own shareholders, and their critics, at home and abroad. Similarly, organisations like the Royal Society had to convince royal and governmental funders, sceptical publics, and their own correspondents and informants, that their inquiries were practically useful rather than nonsensical and possible heretical fantasies. ${ }^{55}$ The concept of hybrid knowledge, as this thesis argues, is useful to examine the knowledge in the Hortus Malabaricus. Winterbottom's works on English East India Company surgeons, botanists and naturalists have provided analytical frameworks for this thesis with which to examine the assimilation of knowledge from the Hortus Malabaricus in Europe in the eighteenth century (see Chapter 3).

From Londa Schiebinger's 'bio-prospecting' model to Anna Winterbottom's 'hybrid' model, the last two decades have seen the emergence of scholarship on the theme of knowledge networks and multicultural production of science. The publication of volumes like the Dutch Company as Knowledge Networks, edited by Siegfried Huigen, Jan L. de Jong and Elmer Kolfin, reflects the change in how the activities of early modern companies are now seen. ${ }^{56}$ The Company trading networks are now analysed not just as commercial networks but also as networks of knowledge. In the Introduction to the volume, the editors wrote, 'the collection of essays bring together a number of case studies of knowledge production which depended on the Dutch trading networks..$^{57}$

While significant works have focused on the networks of knowledge-production, a few works have also explored the artistic angle in botanical knowledge-production. Art historian Daniela Bleichmar's scholarship on botany and visual culture during the Spanish enlightenment joins this significant body of work. ${ }^{58}$ Although commercial networks are not the focus of Bleichmar's analysis, the emphasis on the visual re-construction of the 'visual culture' is noteworthy. This study has benefitted from Bleichmar's analysis of 'decontextualized' images.

\footnotetext{
55 Anna Winterbottom, 'Science' in William A. Pettigrew and David Veevers (eds.), The Corporation as a Protagonist in Global History, c. 1550-1750 (Leiden and Boston: Brill, 2019), p.133.

${ }^{56}$ Siegfried Huigen, Jan L. de Jong and Elmer Kolfin (eds.), The Dutch Trading Companies as Knowledge Networks (Leiden: Brill, 2010).

${ }^{57}$ Huigen, de Jong and Kolfin, The Dutch Trading Companies, p.2.

${ }^{58}$ Daniela Bleichmar, Visible Empire: Botanical Expeditions and Visual Culture in the Hispanic Enlightenment (Chicago: The University of Chicago Press, 2002), p.80; Daniela Bleichmar, 'Seeing the World in a Room: Looking at Exotica in Early Modern Collections' in Daniela Bleichmar and Peter C. Marshall (eds.), Collecting Across Cultures (Pennsylvania: University of Pennsylvania Press, 2011).
} 
Bleichmar argues that most natural history drawings removed 'indigenous' peoples and their contexts to make it a global commodity (see the discussion in Chapter 2 and 3).

Now, in specific to South Asia, environmental history gained currency before a broader framework of history and science and environment emerged. In the last two decades, South Asian historians have responded to the social turn in the history of science. In a 2003 issue of Economic and Political Weekly (EPW), Indian historian of science Deepak Kumar popularized the acronym, HISTEM (history of science, technology, environment and medicine). He wrote, 'the development of a history of science, technology, environment and medicine (HISTEM) in South Asia is not merely to draw on different disciplines, but also has to shape its concerns from unique and divergent regional traditions and histories that prevail in the region'. ${ }^{59}$ In this regard, the work of Dhruv Raina and Irfan Habib is noteworthy. In a collection of essays, Raina and Habib examined various regional histories of how the first generation of Indian scientists domesticated the idea of modern science into their cultural idiom. ${ }^{60}$ This study aims to contribute to this call for understanding the history of science, technology, environment and medicine in South Asia from a regional perspective.

For this purpose, the study has also examined the concept of circulation popularised by historian of science Kapil Raj in South Asian historiography. He argued that early modern science arose from an analysis of the processes of intercultural interactions, encounter, negotiation, and reconfiguration of knowledge. ${ }^{61}$ In his article, 'Thinking Without the Scientific Revolution: Global Interactions and the Construction of Knowledge', Raj criticises the existing literature on nonEuropean conceptions of science as mostly an attempt to complement the single European story by multiplying the histories from non-European regions. Thus, recent scholarship from South Asia has emphasised the role of local people in not just gathering information but also categorising and conceptualising the information that was taken to Europe by colonialists. Scholars have realized the asymmetries in the power relations and the contradictions in these circulatory and network theories of knowledge-production. Still, the gap created by power and patronage in early modern scientific enterprises in South Asia is not fully explored. This study hopes to fill that gap in a minor yet significant way by highlighting the need to look at different empirical and philosophical traditions to understand the history of science.

\footnotetext{
${ }^{59}$ Deepak Kumar, 'Developing a History of Science and Technology in South Asia', Economic and Political Weekly, Vol. 38, no. 23, 2003, pp. 2248-2251.

${ }^{60}$ Raina and Habib, Domesticating Modern Science.

${ }^{61}$ Kapil Raj, 'Ethnolinguistics and Cartography in Early Colonial India', p.274.
} 


\section{Theory}

While networks, hybrid knowledge, connected histories and circulation provide significant frameworks of analysis, this study uses Susan Leigh Star and James R. Griesemer's concept of 'boundary objects' as it broadens the investigation of natural history-production. Star and Griesemer's concept of 'boundary objects' describes the movement of natural history knowledge and physical objects, the connections among different peoples and institutions established by such movement, and the changing meanings and forms ascribed to natural history objects. ${ }^{6}{ }^{2}$ Boundary objects, they define, are 'objects which are both plastic enough to adapt to local needs and constraints of the several parties employing them, yet robust enough to maintain a common identity across sites. ${ }^{63}$ The production of knowledge is a heterogeneous activity. For Star:

Scientific theory [-]building is deeply heterogeneous: different viewpoints are constantly being adduced and reconciled... Each actor, site, or node of a scientific community has a viewpoint, a partial truth consisting of local beliefs, local practices, local constants, and resources, none of which are fully verifiable across all sites. The aggregation of all viewpoints is the source of the robustness of science. ${ }^{64}$

The production of scientific knowledge occurs when different practices, peoples and groups come together to work on a common project. The knowledge moves and takes on different meanings in different contexts. As they move from one place to another, natural history specimens transmit value and meaning. The process of knowledge assemblage is thus a dialectical one in which forms of social space are coproduced. 'Here, a consensus is not necessary for cooperation or for the successful conduct of work. ${ }^{65}$ This theory will form the theoretical framework in the chapters to address the complexities in the knowledge-production in Malabar. As the study will proceed to show, early modern works of natural history, cartography and botany arose from heterogenous spaces - spaces inhabited by people from diverse value systems and empirical practices. The knowledge or information could be produced locally, but it could be exchanged,

\footnotetext{
${ }^{62}$ Susan Leigh Star and James R. Griesemer, 'Institutional Ecology, "Translations” and Boundary Objects: Amateurs and Professionals in Berkeley's Museum of Vertebrate Zoology, 1907-39’, Social Studies of Science, Vol. 19, no. 3, Aug. 1989, pp.387-420.

${ }^{63}$ Star and Griesemer, 'Institutional Ecology, “Translations” and Boundary Objects', pp.387-420.

${ }^{64}$ Susan Leigh Star, 'The Structure of Ill-Structured Solutions: Boundary Objects and Heterogeneous Distributed Problem Solving', in L. Gasser and N. Huhns (eds.), Distributed Artificial Intelligence (New York: Morgan Kauffman Publications, 1989), p.46.

${ }^{65}$ Star and Griesemer, 'Institutional Ecology, “Translations” and Boundary Objects', pp.388.
} 
appropriated, accumulated, and often reshaped and employed in other places. ${ }^{66}$ This particularly holds true in the production and appropriation of the Hortus Malabaricus (as discussed in Chapter 2).

\section{Sources}

For a study of the seventeenth century documents of the Dutch East India Company from the VOC archives, Ann Laura Stoler's 'reading along the grain' is an apt description when analysing the VOC archives. ${ }^{67}$ The National Archives (NA) at Hague, the Netherlands, contain records of erstwhile Dutch colonies and settlements. The archives of the six chambers of the East India Company have documents on the administration of the Company in the Dutch Republic. Each year journals, letters, resoluties (proceedings), dagregisters (diaries), muster-rolls and other documents from the Governor-General and Council in Batavia and other establishments in Asia arrived on returning ships. ${ }^{68}$ The Heren XVII ( VOC board of directors) expected the Governor-General and Council to have all documents of importance to be copied and sent home in six-fold, one copy for each chamber. For visual records, like maps, plans and topographical rolls, 'the Leupe collections' in the National Archives were consulted. These collections of maps are named after Van Leupe, who compiled the various inventories regarding the charts and maps of areas outside the Netherlands. The structure of the Company record keeping was such that the documents were created at the regional offices in the settlements and copies were sent to Batavia, the headquarters of the Dutch East Indies, and to Amsterdam.

For Malabar, as a result, Dutch records are found in a few regional archives. The Kerala Government regional archives at Ernakulam contains letters and copies of land documents loosely classified as Dutch Records written in Malayalam, Dutch and English. Letters of the Cochin Raja to Batavia, sales receipts of local merchants, records on Paliath Achan (Chief Advisory to the rulers of Cochin) etc. are some of the records in this collection. Most of the records available here were

\footnotetext{
${ }^{66}$ For the modern period, James Beattie's work on Thomas McDonnell's garden making and natural history collecting take a similar approach to show how objects transmitted values and meaning as they travelled from one place to other. Beattie's study examines the cultural practices of 'science making', as he argues, established patronage networks connecting peoples and environments. See, James Beattie, 'Thomas McDonnell's Opium: Circulating Plants, Patronage and Power in Britain, China and New Zealand, 1830-50s' in Yota Batasaki, Sarah Burke Cahalan, and Anatole Tchikine (eds.), The Botany of Empire in the Long Eighteenth Century (Washington, D.C: Dumbarton Oaks Research Library and Collection, 2016), pp.165-167.

${ }^{67}$ Ann Laura Stoler, Along the Archival Grain: Epistemic Anxieties and Colonial Common Sense (Princeton: Princeton University Press, 2008).

68 'History of the arrangement of the VOC archives':

http://www.tanap.net/content/voc/history/history managevoc.htm: accessed on 23 August 2019.
} 
compiled by English officials who administered state affairs after 1795, when the Dutch left Fort Cochin.

The huge collection of Dutch manuscripts in Tamil Nadu State Archives (TSA) in Chennai, India, served as the main repository for Dutch records of Malabar. During British rule in Malabar, these Dutch records were transferred to the British office in Madras in 1891. Compared to the well-structured archives in the Netherlands, regional archives in India contain loosely arranged files, some of them without pagination or inventory. All the Dutch files belonging to different years (around 1700) are classified as Cochin Records. I have consulted TSA records of land leases and estate papers for the information on Company gardens and territories. For official correspondences in the final VOC period (1750-1795), the 'Handover Memorandum' (Memorie van Overgave $\mathrm{M \nu O}$ ) are studied to understand the state of affairs in the Dutch forts under various Dutch Commanders. Some of the reports were included in the printed Dutch records by the Madras Government Press (1911). While TSA records offer great possibilities, the Dutch records are discarded and in a dismal physical state. Most records for the initial Company years in Malabar (1663-1740) are missing or in decay.

The chapters of this thesis argue that 'science making' was not in the official agenda of the Dutch East India Company. Thus, the Company archives does not, for example, hold letters of botanical explorations in Malabar. With regards to unofficial records, digitised copies of the Hortus Malabaricus and other natural history are used as evidences to analyse the individual efforts of Company officials in knowledge-production. The Biodiversity Heritage Library website has been consulted for the digitised copies of the printed Latin versions of the twelve volumes of the Hortus Malabaricus. This study has made extensive use of the first and only English translation of the twelve volumes of the Hortus Malabaricus by Prof. K. S. Manilal, copies of which are available in the Kerala State Library, Trivandrum, India. The Leiden University Special Collections, the Netherlands and the Edward Worth Library website, Dublin, provided scanned copies of early modern natural history works. For examining the correspondence networks of botanists, surgeons, naturalists in Europe, proceedings of the Royal Society of London (1700-50) and the journal, Philosophical Transactions of the Royal Society of London, were consulted.

\section{Scope of the study}

The colonial/pre-colonial bifurcation in South Indian historiography has led to the treatment of the trading companies as merely commercial and political competitors for trade on the Malabar coast. Their significance as early modern knowledge networks is an unchartered territory. While 
most literature on early modern scientific enterprises in South Asia focuses on the framework of English East India Company and British rule, this study uses the Dutch East India Company as the framework. A comprehensive study of knowledge-making under the Dutch Company in South Asia or Malabar has not been undertaken, and this makes it furthermore novel. This thesis is, then, a work on the history of science that locates itself within the historiographies of trade, science and environment. The present study particularly seeks to highlight the restrictions imposed by the power relations in early modern scientific practices through the framework of the VOC. In doing so, it analyses the significance of patronage and power in the making of science and related practices. By using the model of 'boundary objects', this study will examine how botanical and geographical knowledge was created across cultures and social groups.

In incorporating familiar sources like the Hortus Malabaricus, the study shows how new methodologies in early modern science give new meanings to these sources, while also being attentive to the former 'peripheral' activities of the Company employees in the settlements. Though the Dutch Company did not succeed in creating an empire in South Asia, this study highlights the disjuncture in the Company's efforts in Malabar and the support from the Dutch Republic. The main research question the thesis has asked is: did botanical and geographical knowledge aid in the territorial expansion of the Dutch East India Company in Malabar? By keeping this core question in the background, the thesis, then, examines how knowledgeproduction occurred and was translated across the VOC world, and in doing so, considers the spaces, actors, agency involved in knowledge-production.

The thesis has moved away from the dominant narrative of science as a tool of empire to show how science alone could not support the economic and political ventures in Malabar. Historians have focused on colonial science as a tool aiding empire-building efforts. Though still the statement might hold true for other European companies, the thesis will show how the Dutch Company failed to use science to further empire-building in Malabar. The thesis reveals that many of the scientific reports on botany, engineering and land management were not taken into serious consideration by the VOC administrative centres in Batavia and Amsterdam. Political power did not always come with enough financial resources which made empire building an uneasy task.

\section{Chapter Overview}

The thesis is divided into five chapters, each discussing a theme relating to knowledge-making endeavours of the Company in Malabar. Chapter One, 'Trade, Culture and Polity in the Dutch Republic, 1600-1700,' locates Malabar within the larger trading world of the Indian Ocean and 
analyses the formation of the Dutch East and West India Companies. The chapter discusses the political history of the Dutch and the Portuguese in Malabar trade. Inspired by Harold Cook's model of the interconnectedness of trade, commerce, art and science, this chapter examines the trade, commerce and science in the Republic. At the beginning of the seventeenth century, the Dutch Republic and Malabar encountered and shaped each other's polity and psyches in myriad and hybrid ways. A discussion of the cultural and political developments in the Republic and the Company in Malabar is set to contextualise the Dutch bio-prospecting efforts in the seventeenth century.

Chapter Two, 'Fashioning Flora: the Hortus Malabaricus and Indigenous Knowledge in Malabar, 1678-1693', introduces the monumental work, Hortus Malabaricus. By building on the impressive body of literature that has surfaced on the relationship between European expansion in Asia and botanical knowledge networks, this chapter focuses on the role of indigenous knowledge in the history of science. This chapter examines the Hortus Malabaricus as an evolving intellectual enterprise that developed alongside the Dutch commercial and scientific networks. The collaborative nature of the work is re-assessed, as the chapter argues that information of Malabar flora was stripped of its cultural context before its 'scientific' rebirth in Europe.

Chapter Three, 'Making Botany: the Hortus Malabaricus in the Republic, 1680-1775', examines the second life of the Hortus Malabaricus outside Malabar. This chapter examines the significance of knowledge of tropical plants from the Hortus Malabaricus in the rise of botany as a formal science in the eighteenth-century Dutch Republic. By describing the development of botanical gardens in Leiden and Amsterdam and many actors involved in its production, this chapter examines the dissemination of knowledge of Malabar plants across different media. This chapter will try to draw out the connections between plants, power and patronage in the early modern Dutch Republic. After a discussion of botanical knowledge-production through the Hortus Malabaricus, the study will move to cartography and geographical knowledge-production in the second half of the thesis.

Chapter Four, 'Dutch Mapmaking: Visual creation of Power in Malabar, 1700-1795', is the first study to use Dutch maps, plans and proposals on Malabar settlements and forts to analyse how knowledge was assembled for making 'Dutch possessions'. Analyses of Dutch mapping practices reflect the different stages of Dutch administration in Malabar. An array of maps, plans, sketches of Company's Malabar settlements are analysed in this section to see how reflective they are of the Company's military and economic ambitions and landed interests in Malabar. This chapter looks at the visual representation of knowledge and the various cost reduction proposals made about the infrastructure in Malabar. 
The fifth and final chapter, 'From Pepper to Property: The Company Gardens in Malabar in the Eighteenth Century (1750-95)', uses official records from the Dutch East India Company archives to examine the reasons for the failure of the Dutch knowledge enterprises in Malabar. Through an analysis of the Company correspondences, mainly reports of Governor Generals and the archival records of Company's gardens and landed estates, this chapter argues that 'science' was not used as an effective tool by the Board of Directors. The knowledge that was produced remained within the scholarly circles in the Republic. The Company could not thereby capitalise on the geographical knowledge its employees produced in Malabar.

This thesis, by looking at the activities of the Dutch Company in Malabar, argues that Company officials in their different capacities attempted various forms of knowledge-production. Sometimes these activities were not knowledge-production per se, but activities that provided context for creating new knowledge of a settlement, like official reports, surveys and plans. But the economic value of Malabar was determined through commercial activities. The Company saw these early 'knowledge-making' activities as expenses, not assets. Additionally, in Malabar, the fate of the Company depended on how effectively it navigated political relations with local rulers. In other words, the Company administration conveniently ignored pleas for botanical expeditions, infrastructural development and territorial expansion from the officers in the Malabar settlements. 


\section{Chapter One}

\section{Trade, Culture and Polity in the Dutch Republic, 1600-1700}

\section{Introduction}

In the early modern period, the type of reasoning that would eventually underlie the later development of a science like ethnography was driven by the recognition of similarities rather than acknowledgments of differences. ${ }^{1}$ Early ethnographic accounts from travellers and missionaries shaped how Europeans imagined Malabar. Ludovico di Varthema (ca. 1468- 1517), an Italian adventurer, wrote the Itinerario (Rome, 1510), an Italian account of his travels in the Middle East and India in which he included one of the first detailed reports of Calicut on the Malabar Coast. He mentioned that the king of Calicut was an idolater yet continued to believe in the Creator. His faith in the Christian God notwithstanding, the king only paid homage to the devil, which he called 'deumo.' From such accounts in the fifteenth century about religion and idols, European understanding of the regions of Asia, Africa and America drastically improved with the opening up of trade routes. With large number of Europeans travelling to Asia as missionaries, East India Company employees and traders, apart from information, goods, spices, furniture and many other costly items also reached Europe. Diplomats, merchants and travellers took note of what they saw and sent back specimens which were displayed in collections, sold in markets or exchanged for other goods. This section of the thesis looks at the movement of material goods, colonial expansion within the backdrop of the formation and extension of trade of the Dutch East India Company.

\footnotetext{
${ }^{1}$ Stephaine Leitch, 'Burgkmair's Peoples of Africa and India (1508) and the Origins of Ethnography in Print', The Art Bulletin, Vol. 91, no. 2, 2009, pp. 145.

2 Raf, Gelders, 'Genealogy of Colonial Discourse: Hindu Traditions and the Limits of European Representation', Comparative Studies in Society and History, Vol. 51, no. 3, 2009, p. 572.
} 


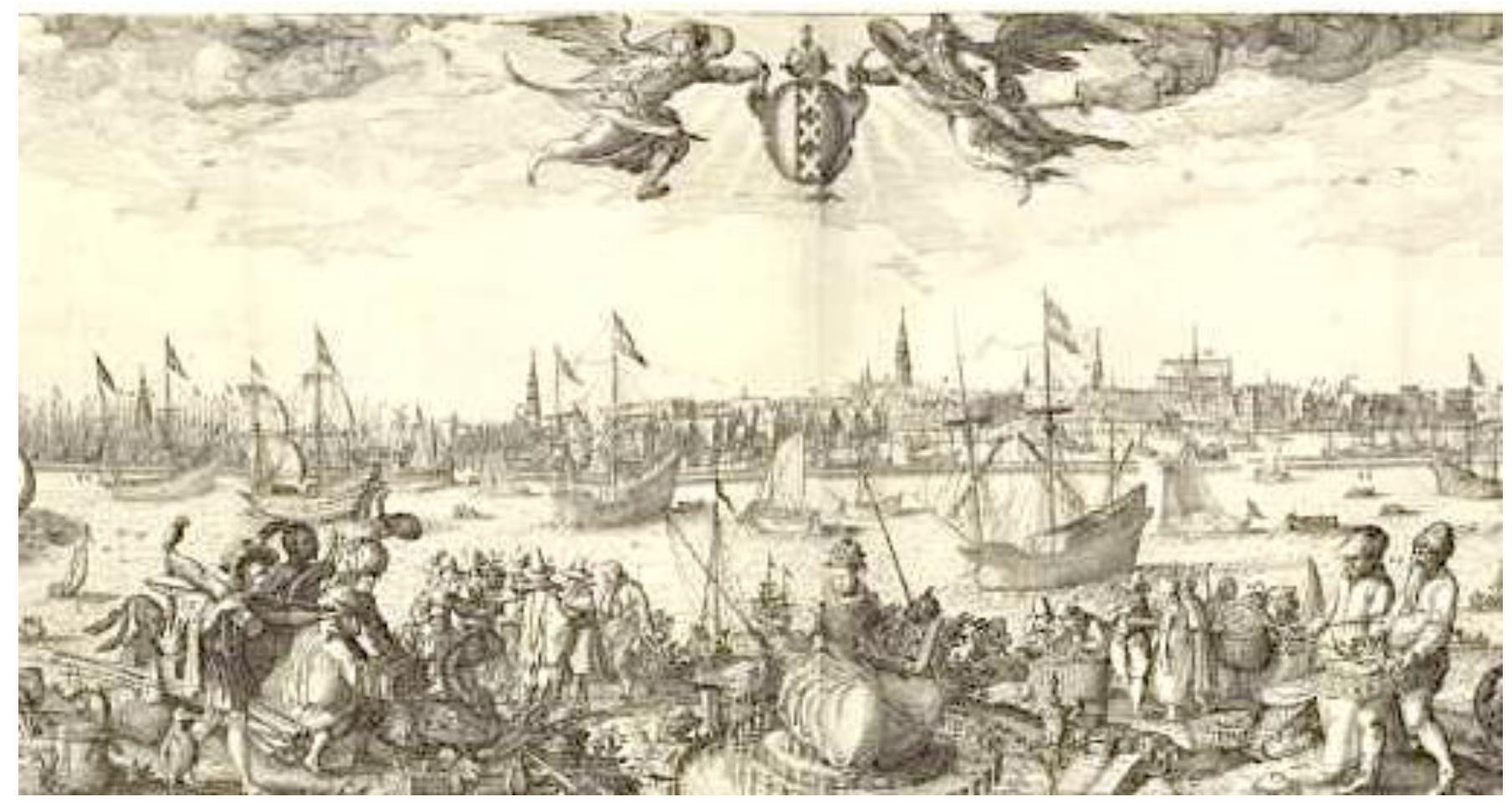

Fig. 1. Claes Jansz. Visscher's profile of Amsterdam, 1611 (Courtesy: Rijksmuseum Collections)

In 1611, the Amsterdam publisher Claes Jansz. Visscher produced a large print of the city's skyline (fig. 1). ${ }^{3}$ In the foreground, a maiden (personifying Amsterdam) sits, surrounded by goods presented to her from all over the world. The accompanying description of the print reads: 'this celebrated global trading capital...the Sun and Soul...of the entire planet'. This statement expresses pride in the city's mercantile fortunes and in the diversity of goods available in Amsterdam in the early seventeenth century. ${ }^{4}$ The skyline of Visscher's profile visually conceptualised the political, cultural and social imagination of Amsterdam commerce. The maiden holds a ship in one hand and the city shield in the other. Around her, a parade of merchants are shown bringing goods (or possibly gifts) from all over the world. The profile depicts merchants from Asia, Africa, and America, bearing rare commodities and sumptuous luxury goods, including pepper, cloves, nutmegs, and porcelain to name but a few. ${ }^{5}$ The maiden sits upon a stage, implying sovereignty over all that lies at her feet—an array of objects, such as books, a miniature globe and so forth. These objects are emblematic of a secular universal wisdom that the society was thought

\footnotetext{
${ }^{3}$ Profiel van Amsterdam, gezien vanaf het IJ, 1611, Rijksmuseum Collection, Ref No. RP-P-OB-103.723, (accessed on www.rijksmuseum.nl 23 May 2020). This profile was based on an earlier engraving by engraver Pieter Baast from 1599. See the earlier engraving, Rijksmuseum Collection, Ref No. RP-P-AO-20-20, (accessed from www.rijksmuseum.nl 23 May 2020).

${ }^{4}$ Karina H. Corrigan, Jan van Campen and Femke Diercks, 'Introduction' in Karina H. Corrigan, Jan van Campen Femke Diercks and Janet C Blyberg (eds.), Asia in Amsterdam: The Culture of Luxury in the Golden Age (London and New Haven: Yale University Press, 2015), p.14.

5 Janet C. Blyberg and Roosmarie Staats in Asia in Amsterdam, pp.52-53.
} 
to embody. The accompanying text further added, 'everything that is merit to the subsistence of the body and to the entertainment of the mind is to be freely found'. ${ }^{6}$ This city profile was a reflection of the thriving commercial scene of seventeenth-century Amsterdam and the pride in the Republic's maritime endeavours. As well, it demonstrates the connection between commerce and science, reading and botany, all of which rested on the freedoms provided by the rising middleclass province of Holland. The image also underlines the strong connection between the reliance of the Netherlands on its overseas territories for the wealth which is displayed in Visscher's print.

In 1600, Holland was one of seven northern provinces of the former Habsburg Netherlands that was engaged in a long war for independence against the Spanish monarchy whose king also ruled Portugal and overseas empire. The Dutch not only freed themselves from the Spaniards but also established a global maritime empire stretching across Asia and the Atlantic. Moreover, the opening of the Amsterdam exchange (1602), modelled on London's Royal Exchange and Antwerp's Bourse, fortified the city's role as a hub of trade connected to all parts of the globe, principally by water. ${ }^{7}$

Historian Catia Antunes argues that for long the Dutch maritime expansion overseas was characterised by the idea of exceptionalism. The chartering of Dutch commercial companies was seen as a milestone of differentiated policy and behaviour, one in contrast with the Iberian empirebuilding experience at the start of the European maritime build up. ${ }^{8}$ This exceptionalism, Antunes argues, came in comparison to Portuguese and Spanish strategies that arose from Dutch early modern discourse that justified their trading companies and a war against Habsburg Spain beyond Western Europe. ${ }^{9}$ Even if the establishment of the trading companies was not exceptional in the European context, the primacy enjoyed by the Dutch in the seventeenth century was significant, both for the Republic and for the regions to which the Dutch trade expanded. This is because the encounters - cultural, political, economic, social and scientific - facilitated by the Dutch overseas trade produced knowledge in myriad ways - knowledge of nature, knowledge of overseas land, knowledge of seas, and knowledge of people. The locations in which this trade occurred-be they ports, ships or Asian courts—were also places of knowledge-making.

In this context, the introductory chapter examines the role of Dutch East India Company trade in the development of an artistic and scientific culture in the Dutch Republic. The chapter

\footnotetext{
${ }^{6}$ Blyberg and Staats, Asia in Amsterdam, p.53.

${ }^{7}$ Claudia, Swan, 'Lost in Translation: Exoticism in Early Modern Holland' in A. Langer (ed.), Art in Iran and Europe in the 17th Century: Exchange and Reception (Zurich: Museum Rietberg, 2013), pp.100-116.

8 Catia Antunes, 'Birthing Empire: The States General and the Chartering of the VOC and the WIC' in René Koekkoek, Anne-Isabelle Richard and Arthur Weststeijn (eds.), The Dutch Empire between Ideas and Practice, 1600-2000 (Cham: Springer International Publishing, 2019), p.19.

9 Antunes, 'Birthing Empire', p.19.
} 
will contextualise the mercantilist values of the Dutch East India Company that shaped early modern scientific culture in Europe. To this extent and in a Dutch setting, the chapter supports Harold Cook's detailed analysis of commerce as the prime factor behind the development of modern science in Europe. ${ }^{10}$ An engagement with the seventeenth century spice trade of the Dutch East India Company in Malabar shows how trade brought people into contact not just with other peoples, cultures, goods and religions, but also with new environments. I argue that Dutch knowledge-making endeavours overseas had a moral and rational origin in the Republic. Trading networks circulated information about navigational routes, forts, territories, land and natural history around the Dutch empire. By taking the framework of the Company, this chapter examines the extent to which knowledge-making or scientific endeavour was facilitated by Dutch overseas trade. The knowledge-making activities were highly heterogenous and involved multiple actors working for the fulfilment of a project. ${ }^{11}$ This chapter uses case studies of groups of artists, traders, merchant elites to demonstrate the manner in which they contributed to early modern experiential science in the Dutch Republic.

The chapter focuses on four themes: the formation of the Dutch East India Company, the Malabar spice trade in the seventeenth century, the economy and the scientific culture of the Dutch Republic. To develop these themes and to understand how Asian trade piqued early Dutch interest in spices, this chapter will examine Dutch trading in Asia, intra-Asian trade and Malabar pepper trade.

\section{Formation of the Dutch East India Company (1602)}

While most other European states were monarchies, the Dutch lived in a Republic. The Republic was a multi-layered society in which power and wealth were distributed both between towns and regions making up the provinces and among patrician families and institutions in the urban centres. ${ }^{12}$ On the levels of both the state and the province, Stadholders (noblemen from the Dillenburg Nassau family) were chosen to represent military interests, but had only limited governing powers. With the decentralisation of power, the Republic was a federalized state in which power lay chiefly with the towns and provinces rather than the court of the Stadholder or the States-General (Staten Generaa). ${ }^{13}$ Prior to the formation of the Dutch East India Company in

\footnotetext{
${ }^{10}$ Cook, Matters of Exchange.

${ }^{11}$ Star and Griesemer, 'Institutional Ecology, 'Translations' and Boundary Objects, p.392.

12 Fokko Jan Dijksterhuis and Andreas Weber, 'The Netherlands as a Laboratory of Knowing: Introduction to Locations of Knowledge in Dutch Contexts' in Fokko Jan Dijksterhuis, Andreas Weber and Huib J. Zuidervaart (eds.), Locations of Knowledge in Dutch Contexts (Leiden and Boston: Brill, 2019), p.3.

13 States General was the sovereign collective body of the Dutch Republic with representatives from all seven provinces.
} 
1602, there were smaller trading companies trading in the East Indies. The first fleet of 1595-1597, organized by the Compagnie van Verre of Amsterdam, demonstrated the possibilities of Asian trade. This led to the setting up of companies in the towns of Amsterdam and Rotterdam, as well as in the province of Zeeland. These companies accumulated capital for one expedition at a time. Nonetheless, there was continuity in the organizational structure of overseas trade. The board of directors and the merchants in charge, or the bewindhebbers (financial agents), sponsored successive expeditions. Each time the ships returned from Asia, investors, who included not only board members but also other shareholders, or participanten, obtained the capital they had contributed, augmented by a share of the profit. ${ }^{14}$ These companies competed fiercely with each other, which put pressure on the profit margins. The years from 1590 to 1602 saw conflict among the various companies to gather state support and spices from the Indies. In some instances, companies bought spices in bulk to ensure they were not available to their rivals. For instance, in $1600 \mathrm{Jacob}$ van Neck, commander of Zeeland's Veersche Company's fleet complained that he was unable to procure sufficient merchandise in Asia to fill even a single ship. ${ }^{15}$ Similar squabbles among companies were also a reflection of the competition among different provinces in the Republic, each of which wanted to pursue its own commercial interests. Both Zeeland and Holland, powerful provinces of the time, posed a great threat to the Republic's unity. Moreover, the unregulated competition between the East India companies created excess demand in Asia, giving local rulers and merchants an upper hand in deciding the prices. The stiff competition in Asian commerce from Iberian empires as well as rivalries among the companies trading in the Indies peaked around 1600. This led the States General to demand a unification of the companies under the banner of a united East India Company. ${ }^{16}$ Thus, the Verenigde Oost-indische Compagnie (VOC) (Dutch East India Company) was born from a fusion of six small companies who were engaged in trading activities.

The VOC Charter of 1602 established the Dutch East India Company with six chambers of the United Provinces: Amsterdam, Zeeland, Delft, Rotterdam, Hoorn and Enkhuizen. The Company also had an Asian headquarter located at Batavia (present-day Jakarta), which carried out the business of purchasing, shipping and selling East-Indian products. The charter stated that

the prosperity of the United Netherlands is principally a result of our shipping trade and commerce that has undergone praiseworthy increases from time to time and that the

\footnotetext{
${ }^{14}$ Femme. S. Gaastra, 'The organization of the VOC' in G. L Balk, F. van Dijk and D. J. Kortlang (eds.), The Archives of the Dutch East India Company (VOC) and the Local Institutions in Batavia (Jakarta) (Leiden and Boston: Brill, 2007), p.14. ${ }^{15}$ Jeffrey Robertson and Warwick Funnell (eds.), Accounting by the First Public Company: The Pursuit of Supremacy (New York and London: Routledge, 2014), p.79.

16 Roberson and Funnell, Accounting by the First, p.77.
} 
Netherlands have been involved therewith since the distant past, not only with the neighbouring kingdoms and regions, but also with those located further away than these in Europe and Asia. ${ }^{17}$

Until 1662, fourteen fleets had been sent, comprising 65 ships. This compared favourably with the total of 59 ships dispatched by the Portuguese in the period from 1591 to $1601 .^{18}$ After the establishment of the Dutch East India Company, 50\% of the European ships that passed the Cape of Good Hope on their way to Asia were Dutch. ${ }^{19}$

The Company was headed by the Heren Zeventien (Gentleman Seventeen, an executive body consisting of the representatives of the six chambers), which was responsible for policy-making and coordinating activities across the chambers. In 1609, the directors decided to place the supreme command in Asia in the hands of a Governor-General, who was to be assisted by a Raad van Indië (Council of the Indies). After numerous negotiations, Batavia was established in 1619 on the site of the Javanese harbour town of Jakarta. This became the seat of the Governor-General and Council or the Hoge Regering (Supreme Government). It became the administrative centre and hub for the Company's shipping traffic for the next hundred years. The Company had a governance structure similar to the Netherlands' States-General and States Provincial, in which real power resided at the local level in the principal towns in which the six chambers were located. Traditionally, the Dutch had invested in commercial undertakings via a financial agent (bewindhebber). With the formation of the Company, anyone could share the Company capital by investing small amounts on their behalf. The charter also permitted the Company to build forts, appoint governors, maintain soldiers and fleets, wage war, and conclude treaties with foreign powers in Asia in the name of the States General of the Dutch Republic. In the years after the formation, the Company was gifted with extensive powers that allowed it to conduct diplomacy, raise armies and seize territorial possessions in Asia. ${ }^{20}$

The VOC had four main headquarters (boofdkantooren) in India: Malabar, Coromandel, Surat and Bengal, each managed by a Director (directeur). ${ }^{21}$ The Company also had subordinate establishments (onderkantoren) managed by Governors (gouverneur) (See Appendix I). The directors

\footnotetext{
17 A translation of the Charter of the Dutch East India Company (de Verenigde Oostindische Comapgnie or the VOC): Granted by the States General of the United Netherlands, 20 March 1602 trans. Peter Reynders in Rupert Gerritsen (eds.), Canberra: Australia on the Map Division of the Australasian Hydrographic Society, ANU, 2009), p.1.

${ }^{18}$ Robert Parthesius, Dutch Ships in Tropical Waters: The Development of the Dutch East India Company (VOC) and Shipping Network in Asia 1595-1660 (Amsterdam: Amsterdam University Press, 2010), p.1.

${ }_{19}$ Parthesius, Dutch Ships, pp.1-2.

20 Adam Clulow and Tristan Mostert (eds.), 'Introduction: The Companies in Asia' in Adam Clulow and Tristan Mostert (eds.), The Dutch and English East India Companies: Diplomacy, Trade and Violence in Early Modern Asia (Amsterdam: Amsterdam University Press, 2018), p.15.

21 These establishments were not specific to a city but denoted an administrative region of the Company.
} 
and local governors gained legal jurisdiction over their employees, possessed jurisdiction over ships and subjects within territorial outposts and rights to wage war. ${ }^{22}$ Of the Indian establishments of the Company, Malabar was attractive for its abundance of black pepper (Piper nigrum, Linn. And kurumulaku in Malayalam or mulakukodi in the Hortus Malabaricus) cultivated in the region. The region received the south-western monsoon (known as Edavapathi in Malayalam) between the months of June and September. Excessive rainfall in some regions made it ideal for the cultivation of pepper, ginger, and nutmeg, as well as other spices. In Malabar, the Company made Fort Cochin (central Malabar) its base of administration, with other forts located in Cranganore, Pallipuram, Purakkad, Kayamkulam, Quilon and Cannanore and military outposts in Cochin, Quilon, Cranganore, Alapuzha, Aycotta, Chendamangalam, Pappinivattom, Ponnani, Pallipuram, Cannanore and Chettuwa at different time periods between 1663 and 1795 (see Map I).

The Portuguese had already established a monopoly on pepper in the region in the sixteenth century. The Dutch Company was not only interested in the Portuguese establishments in Malabar but other spice producing areas. In Ceylon, they tried to replace the Portuguese monopoly in cinnamon, which the Dutch succeeded in doing in $1658 .{ }^{23}$ Malabar thereby served as a strategic location in safeguarding the Company's possessions in Ceylon. ${ }^{24}$ In the process of expanding its power over other regions in Asia, the Company became enmeshed in local networks and rivalries with native rulers in Malabar. In Southeast Asia, the Company was interested in the Maluku Islands, an archipelago in eastern Indonesia known as the Spice Islands, famous for its nutmeg, mace and cloves. Although the Dutch East India Company was not a colonial power, by the second half of the eighteenth century, it had become a sovereign ruler of over two-thirds of the islands of Southeast Asia and was actively involved in various local power struggles. ${ }^{25}$

In a recent work, Exploring Dutch Empire, Catia Antunes has challenged the existing literature on the Dutch East (VOC) and West India Companies (WIC) ${ }^{26}$ by arguing that the Dutch

\footnotetext{
${ }^{22}$ Charles H. Parker, 'Entrepreneurs, families and companies' in Jerry H. Bentley, Sanjay Subrahmanyam and Merry E. Weisner-Hanks (eds.), The Construction of a Global World, 1400-1800 CE Part II: Patterns of Change (Cambridge: Cambridge University Press, 2015), p.210.

${ }^{23}$ Alicia F. Schrikker, Dutch and British colonial intervention in Sri Lanka c. 1780 - 1815: Expansion and Reform (Leiden and Boston: Brill, 2007), p.18.

${ }^{24}$ Pim de Zwart, 'Globalization and the Colonial Origins of the Great Divergence: Intercontinental Trade and Living Standards in the Dutch East India Company's Commercial Empire, c. 1600-1800', PhD Thesis, Utrecht University, 2015 , p.195.

${ }^{25}$ Kwee Hui Kian, 'How Strangers Became Kings: Javanese-Dutch relations in Java 1600-1800', Indonesia and the Malay World, Vol. 36, no. 105, July 2008, pp. 293-307.

${ }^{26}$ The Dutch West India Company (Geoctrooieerde Westindische Compagnie) was established on 3 June 1621, for Atlantic trade by the Heren VII which permitted trade in the Atlantic, mainly, in Brazil, the Caribbean, and North America. The intended purpose of the charter was to eliminate competition, particularly Spanish or Portuguese, between the various trading posts established by the merchants. The VOC became instrumental in the largely ephemeral Dutch colonization of the Americas (including New Netherland) in the seventeenth century. From 1624 to 1654, in the context of the Dutch-Portuguese War, the VOC held Portuguese territory in northeast Brazil, but they were ousted
} 
chartered companies were not created for the efficiency of long distance trade, but instead were mechanisms devised by the States General for the specific purpose of creating empire and projecting power. ${ }^{27} \mathrm{~A}$ similar view is shared by Charles H. Parker, who identifies the joint-stock companies such as the Dutch and the English East India Companies as quasi-states. ${ }^{28}$ Early Company ambassadors in Asia opted for a more direct subterfuge as regularly passing themselves off as proxies of the 'King of Holland' without making any mention of the complicated organisational structure of the company or the fact that it was based in a Republic. ${ }^{29}$ While the maritime ambitions cannot be underplayed, Antunes's argument regarding Dutch imperialist ambitions is significant. This thesis agrees with the view that the VOC for the most part worked as a sovereign organisation wielding its own powers to make decisions in its trade with the native rulers in Asia.

The Dutch East India Company stood at the crossroads of financial innovation and institutionalisation of specific property rights in the Dutch Republic. The VOC was a pioneer in terms of ownership (shares and bonds) and in differentiating between ownership and management (including differentiated liabilities) ${ }^{30}$ It also changed the way in which maritime warfare was used to achieve economic gains by bringing economic interests in Asia under one banner. On the one hand, this helped in avoiding competition between overseas Dutch subjects and in domestic markets and on the other hand, improved in maintaining social cohesion in matters of trade. The companies were private institutions whose ownership could be transferred in primary and secondary markets. ${ }^{31}$ This transferability of property rights through the buying, selling and mortgaging of Company shares was not only a novelty, but also opened the door to multiple innovations in the financial markets of the Republic, especially in Amsterdam. Company ownership remained in the hands of private individuals with less intrusion from the States General in the Company's managerial organization. The rise of European powers in the Indian Ocean was part of a wider process of emerging littoral societies across the entire Eurasian continent. ${ }^{32}$

\footnotetext{
from Dutch Brazil following fierce resistance. The West India Company was comparatively less successful compared to the Dutch East India Company and is not examined as it is outside the purview of the thesis.

27 Antunes, 'Birthing Empire', p. 20.

${ }^{28}$ Charles H Parker, 'Entrepreneurs, Families and Companies', p.209.

${ }^{29}$ Clulow and Mostert, The Dutch and the English, p.14.

${ }^{30}$ Antunes, 'Birthing Empire', p. 20.

${ }^{31}$ Ibid, pp. 20-21.

${ }^{32}$ Jos Gommans, 'Continuity and Change in the Indian Ocean' in Jerry H. Bentley, Sanjay Subrahmanyam and Merry E. Weisner-Hanks (eds.), The Construction of a Global World, 1400-1800 CE Part I: Foundations (Cambridge: Cambridge University Press, 2015), p.192.
} 


\section{Following the Pepper trail: Early European trade in the Indian Ocean}

As mentioned earlier, the Dutch entered a large spice trading circuit of the Indian Ocean of which many regions were already dominated by the Portuguese. Before the Portuguese circumnavigation of the Cape of Good Hope to Asia at the end of the sixteenth century, spices reached Europe over land. ${ }^{33}$ The inland route had enriched coastal Malabar centuries before the arrival of Europeans and their presence in Indian Ocean networks. Vasco Da Gama's arrival in Calicut in 1497 is commented on in the following way in a recent work:

Vasco Da Gama and his men received one courtesy audience from the Zamorin (ruler of Calicut) and they were greatly impressed by the assured opulence of his court. But when they requested an official business discussion, they were informed of the local custom of furnishing presents to the ruler. Da Gama confidently produced twelve pieces of striped cloth, four scarlet hoods, six hats, four strings of coral, a case of six wash-hand basins, a case of sugar, two casks of oil, and two of honey for submission, only to be jeered into shame. For ruler's men burst out laughing, pointing out that even the poorest Arab merchants knew that nothing less than pure gold was admissible at court. ${ }^{34}$

Malabar ports had well-established trade routes by sea from East Africa to South Asia and on to the Spice Islands, China and Japan, connecting places like Zanzibar and Basra to the Coromandel Coast, Java, Banda Islands, Indo China and East China Seas. The trade literature on European spice trade has often overlooked the demand for spices, especially pepper, in the Middle East. ${ }^{35}$ Arab merchants were active in the Malabar ports and most of the rulers who engaged in the spice trade with Arabs had enough resources for overseas trade. Early modern Malabar stood at the centre of the global economy with powerful states that wielded economic, military and cultural resources. In the words of Kerala historian K. M Panikkar, seventeenth-century Malabar was divided into a number of principalities, each ruled by either a king or a Chief, who acknowledged the suzerainty of one of the major rulers of three major principalities (Cochin, Travancore and Calicut). ${ }^{36}$ The fragmentation of a centralized authority in the eleventh century

\footnotetext{
33 Parthesius, Dutch Ships, p.11.

${ }^{34}$ Manu S Pillai, The Ivory Throne: Chronicles of the House of Travancore (Noida: Harper Collins, 2016), p.3.

35 One exception is Sebastian R. Prange, Monsoon Islam: Trade and Faith on the Medieval Malabar Coast (Cambridge: Cambridge University Press, 2018) where the author discusses the early Arab spice trade in the India ocean in the sixteenth centuries.

${ }^{36}$ K.M. Panikkar, Malabar and the Portuguese: Being a History of the Relations of the Portuguese with Malabar from 1500 to 1663 (Bombay: Taraporevala Sons and Company, 1929), pp.7-8.
} 
resulted in new forms of political power structures in Malabar like swarupams ${ }^{37}$ and chiefs such as nadwazhis, desavazhis, kaimals, and karthas. ${ }^{38}$ Swarupams were ruling families which came to control the nadu divisions, following the fall of the perumals of Mahodayapuram. They were large joint families with branches whose political authority was organized on the order of seniority. As such, they owned lands within the territories of major kingdoms and also derived power through matrilineal ties from the Kingdom of Cochin. The newly emerging rulers competed for control of various seaports with a view to gaining a share of maritime trade for their political expansion. Foreign trade started to become concentrated in the major port cities, encouraging local rulers to convert their port towns to chief bases for exercising power. Indian historian Pius Malekandathil argues that a hierarchical structuring of the Malabar ports occurred with one principal port giving way to another in the backdrop of changing geo-physical environment and coastal politics. ${ }^{39}$ In vying for trade, local rulers either shifted the headquarters of their kingdoms to the commercially prominent port-area or conquered other potential maritime exchange centres of other kingdoms.

The Portuguese trade in the Indian Ocean began with what can be summarised in Vasco da Gama's words upon his arrival in Calicut: 'We come in search of Christians and spices'; though spices were definitely the primary motive. ${ }^{40}$ Black pepper was the single most important ingredient of the Indian Ocean spice trade. ${ }^{41}$ In the seventeenth century medico-botanical text, Hortus Malabaricus, pepper is said to be grown in the whole of Malabar. ${ }^{42}$ Before the arrival of the Portuguese in Calicut (1498), Duarte Barbosa reported that every sailing season ships carrying a total of 1,200 bahär (spice mixture used in Middle Eastern, Turkish and Greek cuisines) left from Calicut alone. Throughout the sixteenth and first half of the seventeenth century, an overwhelming proportion of pepper imported into Lisbon was procured from Malabar. Against the total of approximately 17,200 quintals (one quintal equals 100kgs) imported into Lisbon in 1506, the average amount imported from Cochin alone during 1506 and 1507 was 13, 214 quintals. The pepper procured from Malacca (coastal state of Malaysia) accounted only for 3.26 per cent of the total pepper shipped to Lisbon compared to the bulk of pepper exported from Malabar. ${ }^{43}$ The production of pepper in Malabar in the sixteenth century is estimated in the range of 5,000 to 15,000 tonnes per year and was sold not only to the Portuguese but also to the Muslim trading

\footnotetext{
${ }^{37}$ See M. R Raghava Varier, 'Swarupam as state: An Introductory Essay' in R. Champakalakshmi et al. (eds.) State and Society in Pre-modern South India (Thrissur: Cosmo books, 2002), pp.120-130.

38 Pius Malekandathil, 'Coastal Polity and Changing Port Hierarchy of Kerala' in Yogesh Sharma (ed.), Coastal Histories: Society and Ecology in Pre-modern India (New Delhi: Primus Books, 2010), pp.80-81.

${ }^{39}$ Ibid, p. 80.

40 Prange, Monsoon Islam, p. 211.

${ }^{41}$ Ibid, p.208.

${ }^{42}$ Adriaan van Rheede, Hortus Malabaricus, trans. K. S. Manilal (Thiruvananthapuram: University of Kerala, 2003$)$, Vol. 7, Fig. 12, p.46.

43 Prange, Monsoon Islam, p. 212.
} 
partners, such as the Karimi merchants who sailed between Egyptian ports and the Indian Ocean. ${ }^{44}$ Most shipments in the sixteenth century never reached Europe but were consumed in Yemen, East Africa, the Hijaz, the Levant, Egypt, the Maghreb, Anatolia and so forth. ${ }^{45}$ At least up to 1659, trade carried by Europeans in Asia comprised only a modest share of total Asian trade. ${ }^{46}$

Pepper was initially procured at Calicut, where Vasco Da Gama's fleet first arrived, but soon relations of the Company with the Zamorin (title of Calicut ruler) and merchants deteriorated. The centre of trade then shifted to Cochin. Cochin had emerged as a port in 1341 following the great flood in Periyar. It played a subordinate role as a trading port to the port of Calicut. The beginnings of the transition of Cochin from the status of a feeding port to that of a pivotal port started with the coming of the Portuguese in the 1500s. Cochin was made the political capital of the Portuguese trading Company (until 1530) and eventually became the focal point of the Indian Ocean trade. ${ }^{47}$ The Portuguese tried to keep the major spice producing centres of Kerala integrated with the circuits of the Cochin-Lisbon commercial axis by erecting minor forts and trade centres at Chaliyam, Ponnani and Palayur, besides the fortress and factory at Canannore. Lusitanian mechanism of coastal patrolling forced the movement of commodities to the port of Cochin, making it Portugal's key port of Kerala in the evolving port hierarchy in the sixteenth and seventeenth centuries. ${ }^{48}$ Cochin was also considered to be more welcoming for trade with its cooperative Mappila Muslim and Syrian Christian merchants as intermediaries. (The role of intermediaries in Malabar trade is discussed in Chapter 5).

Portugal created a stimulus for intra-Asian trade within the Indian Ocean network. The intra-Asian trade of the Portuguese was considerably larger in value and substantially more lucrative than the Lisbon-Goa trade. As historians Sanjay Subrahmanyam and Luis Filipe F.R. Thomaz note, in the first half of the sixteenth century, Portuguese India did not represent 'a space that was geographically well defined but a complex of territories, establishments, goods, persons and administrative interests in Asia and East Africa, generated by or subordinate to the Portuguese Crown, all of which were linked together as a maritime network. ${ }^{, 49}$ Historian Om Prakash argues that the context in which international consortia and merchant enterprises grew in Europe

\footnotetext{
${ }^{44}$ Ibid, p.215. For a critical discussion on the conventional historiography that focuses on the European spice trade in the sixteenth century, see chapter 4.

45 Prange, Monsoon Islam, p.214.

46 Tonio Andrade, 'The Dutch East India Company in global history A historiographical reconnaissance' in Adam Clulow and Tristan Mostert (eds.), The Dutch and English East India Companies: Diplomacy, Trade and Violence in Early Modern Asia (Amsterdam: Amsterdam University Press, 2018), p. 244.

${ }^{47}$ Malekandathil, 'Port Hierachy in Kerala', p. 82.

48 Ibid, p. 84.

${ }^{49}$ Sanjay Subrahmanyam and Luis Filipe F.R. Thomaz, 'Evolution of empire: the Portuguese in the Indian Ocean during the sixteenth century', in James D. Tracy (ed.), The Political Economy of Merchant Empires, State Power and World Trade 1350-1750 (Cambridge: Cambridge University Press, 1991), p.304.
} 
influenced the way in which Portuguese Estado (East India Company) shaped its maritime network. ${ }^{50}$ Until the English and the Dutch challenge in the last decade of the sixteenth century, the Portuguese enjoyed a largely unchallenged monopoly of trade along the Cape route.

Portuguese officials and employees of the Crown were also actively involved in the intraAsian trade. This also meant that the fluidity of goods increased within Asian ports and towns. Despite the declining Portuguese trade in Asia in the seventeenth century, private intra-Asian trade continued to support the Luso-Asian communities in India and China well into the eighteenth century. ${ }^{51}$ The bulk of intra-Asian trade was left to Asian competitors and private Portuguese settlers (casados, many of whom were converted Jews, known as 'New Christians' who often married local women). They were mostly located in the port cities of the Arabian Seas, such as Cochin, Goa, Colombo and so forth. By the end of the seventeenth century, the Portuguese ability to hold command over the western seas and coasts was declining significantly. The relationship with the merchant networks also did not endure. By the end of the third decade of the seventeenth century, Malabar merchants declared a war against the Portuguese Estado da India. ${ }^{52}$

\title{
The Dutch in Cochin: New actors in spice trade
}

\author{
'As the Portuguese are on the other side. \\ The Portuguese who held the Cochin Fort \\ If expelled, the dream is materialized. \\ Hearing these, the governor said sans hesitancy: \\ Just after killing the enemies \\ I will coronate you dutifully. ${ }^{, 53}$
}

The above excerpt is from a Patapattu (or war-song, in Malayalam) that describes the Dutch conquest and expulsion of the Portuguese from the lands earlier owned by the ruler of Cochin. The song refers to the events of 7 January 1663 when the Dutch fleet under Commander Rijklof

\footnotetext{
${ }^{50} \mathrm{Om}$ Prakash goes on to argue that it is difficult to imagine a scenario that the Portuguese enterprise would have taken in the absence of consortiums and networks that were rising in Europe. It is also useful to remember that these consortiums were central not only to the European end of the Portuguese empire but also to its Asia end. Om Prakash, 'International Consortiums, Merchant Networks and Portuguese Trade with Asia in the Early Modern Period', Paper presented at Session 37of the XIV International Economic History Congress, Helsinki, 21-25 August, 2006 , p.4.

${ }^{51}$ Gommans, 'Continuity and Change', p.193.

${ }^{52}$ For more on the early Portuguese trade in India see, M. N. Pearson, The Portuguese in India (Cambridge: Cambridge University Press, 1987); Pius Malekandathil, Portuguese Cochin and the Maritime Trade of India 1500-1663 (New Delhi: Manohar, 2001); K. S. Mathew, Portuguese Trade with India in the Sixteenth Century (New Delhi: Manohar, 1983).

${ }_{33}$ Pattapattu is a pre-modern Malayalam literary genre that is roughly translated as war-songs. They form part of the folklore literature in Malayalam. See the full translation of the song in Appendix I.
} 
van Goens took control of the Cochin Fort from the Portuguese. In Malabar, the ruler of Cochin became the VOC's main ally after the Dutch Commander assisted him in battle against the ruler of Calicut (who sided with the Portuguese). Upon victory in Cochin, the VOC concluded a treaty with the King of Cochin, Rama Varma, whose lost possessions and title were both restored by the Dutch Governor. The treaty stated that 'the town of Cochin shall be given (to the Dutch) with all jurisdictions, old privileges, revenues, lands and fields with the documents and papers thereof and with whatever more has been possessed in the name of the king of Portugal, giving over all claims and rights thereon to the Commander or his representative. ${ }^{54}$ Since then, the Dutch entered into various treaty agreements with local rulers for procuring pepper from their kingdoms. On 14 March of the same year, the Dutch Commander, Rijklof van Goens, signed another treaty with the ruler of Cochin and one of the chiefs of his principality, Chempakasseri Swarupam. The treaty stated that, 'there shall be among the parties everlasting peace, amnesty and forgetfulness of what had happened before... and lasting love and benevolence as long as the sun and the moon shine, ${ }^{55}$

The first Dutch treaty (January 1663) with the ruler of Cochin was not merely a trade agreement; it was an attempt to bring the territory's peoples, lands, and trade under the Company's jurisdiction. A third treaty signed between Van Goens and the king of Cochin makes this clear. The treaty laid out conditions, such as 'the king of Cochin shall cede the right of the town (Cochin) and all of the lands, rivers and islands (Papist, Musquito, Benduruthy) that were earlier possessed by the Portuguese forever' so that the successors of the king would not make a claim at a later stage. ${ }^{56}$ Another condition stated that the King of Cochin was required to sell all pepper and wild cinnamon harvested in his lands and in Porca and Cranganore (areas whose chiefs sided with Cochin) to the Company alone. The Christians residing in the town of Cochin would remain under the jurisdiction of the Company under the treaty. ${ }^{57}$

Malabar was initially placed under the Dutch government in Ceylon administered by the Commander of Ceylon, Rijklof van Goens, but in 1670, Malabar was made a separate Command with its own Commander, Hendrik Adriaan van Reede. This was the beginning of years of long rivalry between Rijklof van Goens and Hendrik van Reede, as they fought for Company patronage for their respective establishments. This rivalry, as the present thesis shows, had far-reaching implications for Malabar's development, including its administration and scientific investigation. Van Reede was considered as one of the ablest Dutch commanders in Malabar for his in-depth

\footnotetext{
54 Treaty 1663, Central Records, Ref. No. T. 90 (non-paginated), Kerala State Archives (KSA), Ernakulam. These files are randomly collected Dutch records kept by the British during their time in Cochin.

55 Ibid.

56 Treaty signed between Rijklof van Goens and Malabar Princes, Central Records, Ref. No. T. 21, (KSA).

${ }^{57}$ Ibid.
} 
understanding of the social and political affairs in the region. Writing in 1675, Van Reede noted, if the Company wants to procure pepper in Malabar, they must behave as merchants and follow the market'. He added, 'since the pepper belongs to the merchants and not to the kings or the landed gentry, no more is gained by an exclusive contract than the right of expropriation'. ${ }^{58}$ The VOC did not pay prices based on a market price determined by supply and demand, but paid a contract price negotiated with local sellers. Thus, the relation with local rulers was significant in the international and intra-Asian trade.

The Malabar Command of the VOC consisted of numerous fortresses, warehouses and military posts spread along the coast and in the hinterland. Cochin was the headquarters to which all smaller establishments reported, while Cochin was accountable to Batavia and received instructions from the High Government there on 'matters ranging from policies towards local chiefs to postings of its servants; from about pepper and its collection to the piece-goods obtainable in Malabar which could be sold profitably elsewhere, and from rice for Ceylon to young boys and girls to be sold as slaves in Batavia. ${ }^{59}$ In the sixteenth century Cochin was a heterogenous society that included migrants and settlers from parts of India, Asia, and Europe. At the time of the Dutch conquest in 1663, there were about 900 houses in the Portuguese quarter. By 1700, there were 488 VOC servants residing in Fort Cochin; the number rose to 829 by $1730 .{ }^{60}$

\section{Dutch intra-Asian trade}

In the second half of the seventeenth century, the Dutch had control over the earlier Portuguese controlled intra-Asian trade networks, especially those connecting South Asian and Southeast Asian ports. The Dutch trade in the seventeenth-century Indian Ocean meant that there was now a sole trading organization that was willing and able to undertake transportation over the whole route, from the production centre to market. This was different from the Portuguese trade in the sixteenth century. Effectively, the VOC brought together more than two trade circuits for connecting East and South Asian trade. For instance, Batavia emerged as the new Southeast Asian port of prime importance, replacing earlier Portuguese centres of Malacca and Bantam; at the same time, the Company could bring Japanese copper to markets in Surat and take spices from Indian

\footnotetext{
58 Memoir written in the year 1677 A. D. Reede tot Drakenstein, Hendrik van, 1637-1691 (Madras: Madras Government Press, 1911), p. 135.

${ }^{59}$ Singh, Fort Cochin Kerala, p. 41.

${ }^{60}$ Ibid, p. 43.
} 
ports to be sold in Persia. ${ }^{61}$ An account of ship from 1670-71 kept in the Batavia Daily Register (Dagh-register) $^{62}$ lists the following items taken in a Dutch yacht named Rammeken (belonging to Amsterdam chamber) ${ }^{63}$ from Batavia to Persia: 30000 Japanese copper (Japans kooper) in 300 boxes, 20121 cloves (nagelen), 50195 gum lacquer (gommelack), two loads of fine steel (smeekoolen), and one box of medicines among other things. ${ }^{64}$ The entry further lists details of another yacht that departed on the same day, De Cogge, that took 2006 cloves (nagelen), 1041 and half nutmegs (foely), 250 pieces of Japanese pottery, two boxes of medicines and other provisions for warfare to Cochin. The daily register notes that the second yacht 'had nothing to deliver at Cochin but had to procure pepper for supplying it to other ports'. ${ }^{65}$ The items procured from Indian ports were also distributed to other parts of Southeast Asia. A letter dispatched by the Governor-General, Joannes Camphuys and his Council at Batavia to the king of Siam, Phetracha, provided a list of the following items procured mainly from the Coromandel coast of South India; these were being sent as 'token of His Majesty's (Siamese ruler) excellent, honest and sincere favour to the Company':

\author{
1,040 pieces of common bleached selampuri (cotton cloth from Coromandel coast of \\ south India) \\ 2,080 pieces of 'pulong gabar' (printed cotton cloth from Coromandel) \\ 600 pieces of Malay serasah (Coromandel chintz) \\ 100 pieces of hamman \\ 140 pieces of chintz. (printed or painted calico) \\ 40 pieces of gold and silver allegia (striped cotton textile from Coromandel) \\ 11,325 pounds of sandalwood \\ 732 pounds of cloves \\ 600 pounds of nutmegs \\ 308 pounds of mace \\ 640 sticks of cinnamon \\ 6 marble statues. ${ }^{66}$
}

\footnotetext{
${ }^{61}$ Gommans, 'Continuty and Change', p. 195.

${ }^{62}$ Dagh registers or diaries are part of the archive of the High Government that were created by the Governor-General and the Council at Batavia and contain mostly repertories and indexes of important documents for the years 16021827. The official diaries of the years 1624-82 were published by the Dutch government between 1887 and 1931.The present study has used the published diaries from the archives.

${ }^{63}$ As mentioned in the recent database of the VOC journeys to Asia, see http://resources.huygens.knaw.nl/das/search last accessed 15 April 2020.

${ }^{64}$ Dagh-register gehouden int Casteel Batavia vant passerende daer ter plaetse als over geheel Nederlandts-India 1670-71 (Batavia: G. Kolff, 1989), p. 141.

${ }^{65}$ Dagh-register 1670-71, p.141.

${ }^{66}$ Dagh-register gehouden int Casteel Batavia. May 1689: fol. 291. Also cited in Hendrik E. Niemeijer, 'Letter from the Phrakhlang on behalf of King Phetracha of Siam (r. 1688-1703) to the Supreme Government', 12 February 1689 and the answer from Batavia, 4 Mei 1689 in Harta Karun. Hidden Treasures on Indonesian and Asian-European History from the VOC Archives in Jakarta, Document No. 19. (Jakarta: Arsip Nasional Republik Indonesia, 2016). Accessed via the digital collections of the National Archives of Indonesia, https://sejarahnusantara.anri.go.id/hartakarun/item/19/transcription, accessed on 11 June, 2020.
} 
By the seventeenth century, pepper was also imported from the Southeast Asian islands reducing the sole dependency on the pepper producing regions in Malabar. Historian Anthony Reid suggests that pepper was introduced by the Chinese in Java and Sumatra only in the sixteenth and seventeenth centuries. ${ }^{67}$ Until then, Malabar was the sole exporter of pepper to the rest of the world. Now, let us examine the arrival of spices in the economy of the Netherlands.

\section{A Republic of 'new' commodities}

The rise of the Dutch East India Company coincided with, and contributed to, significant socioeconomic change in the Dutch Republic, the most apparent of these being the rise of a vibrant middle class that could afford the luxury items. If traditionally the luxury items in Europe were mainly gold, silver and gems, the seventeenth century saw new items whose value lay not so much in the cost of the materials as in the quality of their craftsmanship (for example, Chinese porcelain). ${ }^{68}$ East Indies shops (winckel van Oost-Indische waeren) opened in Amsterdam and solely traded in the goods from the East Indies. ${ }^{69}$ The rarity and the status of "exotic" goods mattered a great deal in the Republic. The trade in pepper, cloves, nutmegs, cardamom, and cinnamon-used both in cooking and for medicinal purposes_-was the mainstay of the Company's commerce in the early seventeenth century. The ships also carried boxes of medicines from Batavia to Persia and India (for the Company crew). ${ }^{70}$ Spices such as cloves, cinnamon, coriander and ginger were often mixed with honey into sour white wines, commonly imported from the French and German regions. Spices also acted as tokens of diplomacy between the rulers in Asia and the Company. In a letter of 1696 written by the ruler of Cochin to Batavia, the ruler requests the Company's assistance in safeguarding his territories from the annexation by the ruler of Calicut. Along with the letter, he sends 'a gold bangle and some pepper' as a token of goodwill. ${ }^{71}$ In this sense, spices were more than simply bulk commodities: they became symbols of diplomatic relations between Asian and Dutch authorities.

\footnotetext{
${ }^{67}$ Anthony Reid, Southeast Asia in the Age of Commerce, 1450-1680: Volume 2, Expansion and Crisis (Yale: Yale University Press, 1995), p.12. Long pepper comprises two taxa, Indian long pepper and Javanese long pepper. For a detailed discussion of the differences in the varieties, see, Sebastian Prange, 'Measuring by the bushel: Reweighing the Indian Ocean Pepper 'Trade', Historical Research, Vol. 84, Issue no. 224, 2011, pp. 226-228.

${ }^{68}$ Corrigan, van Campen and Diercks, Asia in Amsterdam, p. 15.

${ }^{69}$ Jaap vaan der Veen, 'East Indies Shops in Amsterdam' in Corrigan, van Campen and Diercks, Asia in Amsterdam, p.137.

${ }^{70}$ Dagh-register gehouden int Casteel Batavia 1670-71 records at least 47 entries of ships carrying boxes (mostly one or two) of medicines to Persia and India.

${ }^{71}$ Series files (1684-1869), File No. E. 10 (non-paginated), KSA. As a response to this request, the Company entered into another treaty (on 6 April 1698) with the ruler in which the ruler was given right to export 500 candies of pepper to Coromandel and to Persia and Mecca; but the treaty nevertheless added a clause which prohibited the ruler to ask for more concessions.
} 
Until the Portuguese first arrived at the Malabar coast in 1498, spices had been carried overland from Asia to Venice to Genoa, and then sold at European markets. Once Dutch ships were barred from trading in the port of Lisbon, Dutch merchants were forced to trade directly with Asia. ${ }^{72}$ The Dutch called pepper their 'black gold'. ${ }^{73}$ The Dutch word 'peperduur', literally means 'as costly as pepper' and originates from pepper's high prices and rarity in the sixteenth and the beginning of the seventeenth century in the Netherlands. ${ }^{74}$ The VOC charter of 1602 states that, 'should one Chamber or another have received spices or other merchandise from the Indies, and other chambers have none or have not yet received any, the Chamber that has been stocked up, shall supply the other Chambers according to its ability and send them the merchandise, and more should they have again sold out, if so requested. ${ }^{75}$ Thus, from the beginning, any attempt to monopolise spices by a single chamber was controlled by dividing the supplies across Chambers. The Company imported four million pounds of pepper annually in the seventeenth century.

The arrival of pepper in the Republic shaped the imagination of Dutch artists and painters. The sensual and the visual allure of Asian imports added to their popularity as status symbols. The Dutch artists who were inspired by the new sensory delights brought by foreign goods, modified and incorporated them in their still life paintings and artisanal practices. ${ }^{76}$
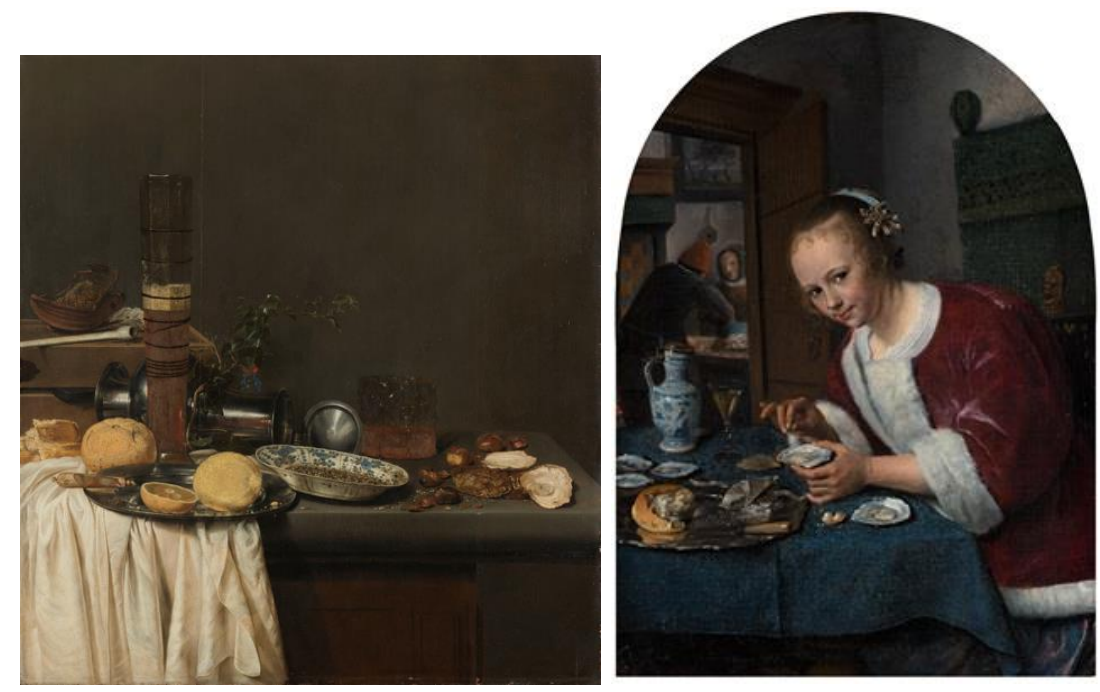

Fig 2. Still Life with Beer Glass by Jan Jansz. Van de Velde III (Courtesy: Rijksmuseum Collections) and fig. 3.

Girl eating Oyster by Jan Havicksz (Courtesy: Maurtishuis Collection)

\footnotetext{
72 Dirk Jan Biemond in Asia in Amsterdam, p.66.

${ }^{73}$ Marcus P.M. Vink, Encounters on the Opposite Coast: The Dutch East India Company and the Nayaka State of Madurai in the Seventeenth Century (Leiden and Boston: Brill, 2015), pp.193-194.

${ }^{74}$ Roosmarie Staats, in Asia in Amsterdam, p.274.

75 A translation of the Charter of the Dutch East India Company, p.3.

${ }^{76}$ Corrigan, van Campen and Diercks, Asia in Amsterdam, p.16.
} 
Dutch still life paintings of the seventeenth century often showed peppercorns or ground pepper placed on lavishly set dinner tables or as a seasoning alongside large feasts. For instance, consider the painting (fig.3) 'Girl Eating Oysters' (1660) by artist Jan Havicksz Steen, in which a girl is seasoning oysters with pepper. ${ }^{77}$ The second still life painting on the left (fig. 2$)^{78}$ shows pepper contained in a Chinese porcelain dish alongside other expensive items, such as tobacco (possibly from South America in this period), ${ }^{79}$ which had reached the Netherlands through trade. ${ }^{80}$ Many Dutch still life paintings were conceptually linked to the flourishing trade of the Republic and the new commodities available in the market. Actual luxuries in homes, then, were supplemented by the sale of artworks and decoration, both contributing to and representing this new-found Dutch wealth, grounded in overseas trade with Asia.

As commercial cities like Amsterdam produced capital for the political systems, the values of urban merchants, including their intellectual values, filtered through society. ${ }^{81}$ The emerging elite had extensive collections of goods from the East Indies in their Cabinets of Curiosities. Cabinets of curiosities or "wonder rooms" (Wunderkammer) were small collections of exotic and odd objects that housed the wonders and oddities of the natural world to a microcosm. ${ }^{82}$ In the seventeenth century, collectors gathered natural specimens in these cabinets where art and nature were displayed as playing off each other. ${ }^{83}$ Many such cabinets were arranged to display, and evoke wonder at the variety and abundance of curious objects of nature. Amsterdam burgomaster (Mayor), Nicholaes Witsen (who served in the post thirteen times from 1682-1706), held collections of drawings and sculptures from India. In 1716, he received twenty-three bronze statues of gods from a Company ship. One sculpture was that of Ganesha, the Hindu god from Malabar, which the Dutch had acquired during their expedition against the Raja of Parur in $1691 .^{84}$ Upon receiving the idols, Witsen found them 'quite repulsive monstrosities with bodies that have elephant's trunks, bird beaks or lions and dragons' ${ }^{85}$ These differences made the East Indies goods more curious and worth possessing.

\footnotetext{
77 'Het oestereetstertje' by Jan Steen, c. 1658-1660, Inventory no. 818. Mauritshuis, The Hague. (Accessed from https://www.mauritshuis.nl/nl-nl/verdiep/de-collectie/kunstwerken/het-oestereetstertje-818/detailgegevens/, March 2019).

78 'Still Life with a Tall Beer Glass by Jan van de Velde (1647)', Object no. SK-A-2362, Rijksmuseum Collections, Amsterdam (accessed from www.rijksmuseum.nl 12 July 2019).

${ }^{79}$ Tobacco was introduced in Malabar by the Portuguese in the sixteenth century and more extensively traded by the Dutch in the eighteenth century. (See Chapter Five of the thesis). The tobacco was mostly used in intra-Asian trade. 80 Although oranges began to be grown in the sixteenth century in hot houses, most still came from Mediterranean trade (detailed in Chapter Three).

${ }^{81}$ Cook, Matters of Exchange, p. 411.

${ }^{82}$ Lorraine Daston and Katherine Park (eds.), Wonders and the Order of Nature, 1150-1750 (New York: Zone Books, 1998), p. 265.

83 See Daston and Park, Wonders and the Order of Nature, pp. 264-265.

${ }^{84}$ Marion H. Peters, in Asia in Amsterdam, p.202.

85 Ibid, p. 202.
} 
Historian P. J. Rietbergen calls the Dutch republic in the 'golden age ${ }^{, 86}$ a 'burgher state' due to the increasing visibility and influence of the bourgeois elite. The role played by nobles and clergy in patronizing arts was almost entirely taken over by the burgher elite. ${ }^{87}$ The possession of goods, naturalia and other exotic collectibles indicated the high status enjoyed by the individuals. The change in consumption patterns and demand for exotic goods were not specific to the Netherlands, but, as Simon Schama has argued, Dutch wealth created a predicament and confusion which set them apart from the rest of Europe. It created both a moral problem, related to biblical teachings around accumulating wealth. ${ }^{88}$ This can be best exemplified in what came to be known as Tulipmania. ${ }^{89}$ As noted, collecting in the seventeenth century was a fashionable activity for European elites. In the mid-1630s, tulips (introduced from Turkey) became one of the costliest collector's items. Historian Anne Goldgar argues that as luxury objects, tulips fitted well into a culture of both abundant capital and new cosmopolitanism. Dutch botanists soon learned that new bulbs would develop either from seed, after five-to-ten years, or from bulb offsets within a few years. Armed with this knowledge, bloemisten (horticulturalists), including the great Leiden botanist Carolus Clusius, tried to create new varieties by using various methods, from crosspollination and grafting to alchemical solutions. The craze for the Tulip is one of the many examples of how global trade shaped the materialistic and visual culture of the Republic. Tulips 'required expertise, an appreciation of beauty and the exotic, and, of course, an abundance of money'. ${ }^{90}$ The emerging mercantile class in Dutch society aspired to possess all these attributes.

While Schama focused on the ideas around the republic's wealth, Harold Cook argues that the commerce of the Republic and the influx of goods from other parts of the world were decisive in the creation of a natural philosophy. Cook argues that a materialist epistemology lay at the heart of the changes whereby medicine and natural history rather than matter theory or mathematical physics became 'the big sciences in the Dutch Republic and throughout Europe'. ${ }^{91}$ The cultural development of science in the seventeenth century is also inter-linked, and visible in institutions

\footnotetext{
86 The widely used term 'Golden Age' for the seventeenth century Dutch Republic is challenged here as part of the wealth of the period came from slave trade. This thesis, therefore, does not use the term to denote seventeenth century Dutch Republic as the Golden Age unless when quoting secondary readings. See more in Nina Siegal, 'A Dutch Golden age? That's Only Half the Story', New York Times, 25 October 2019. https://www.nytimes.com/2019/10/25/arts/design/dutch-golden-age-and-colonialism.html accessed 23 February 2020)

${ }^{87}$ P.J. Reitbergen, $A$ short history of the Netherlands (Amersfoort: Vanderheide Publishing Co., 2004), p.103.

88 Simon Schama, The Embarrassment of Riches: An Interpretation of Dutch culture in the Golden Age (New York, Vintage Books, 1998), p.8.

${ }^{89}$ Tulip mania was a period in the seventeenth century during which contract prices for some bulbs of the recently introduced and fashionable tulip reached extraordinarily high levels in 1636 and then dramatically collapsed in February 1637.

${ }^{90}$ Anne Goldgar, Tulipmania: Money, Honor and Knowledge in the Dutch Golden Age (Chicago and London: University of Chicago Press, 2007), pp. 67-69.

${ }^{91}$ Cook, Matters of Exchange, p.410.
} 
and activities, such as the botanical gardens, scientific mapping, scientific instruments, printing and illustration, many of which concentrated on understanding and displaying goods from Asia.

\section{Malabar in Print: (Re)Presenting Malabar through visual narratives}

The connection between Asia and key technological and social developments is illustrated by the development of printing. The emergence of the printing press in mid-fifteenth-century Europe, especially moveable metal type, occurred at a time when the Italian Renaissance was in full bloom. Growing literacy during the sixteenth century resulted in innovations in book markets with steady demand for books from outside Europe. ${ }^{2}$ This led to the production of many ethnographic, religious and administrative works on India creating an image of Indian community life.

Before seventeenth-century European interactions with Asia, images of the latter mainly came from scholars, travellers, missionaries and merchants. Curiosity about the lands of riches or 'others' occupied European minds. The reason was mostly due to the fragmented information at irregular intervals. ${ }^{93}$ In the European popular imagination and in many scholarly treatises, the mythical and the real attributes of Asia often remained undifferentiated. The works of the historians of Alexander and the account of Megasthenes set the image of India for the Greek world. Although the original books perished, their contents were preserved by being incorporated into the works of writers such as Strabo and Pliny. From these accounts there emerged in Europe a picture of India as a land of gold and precious stones. These accounts were influential because of the Renaissance's emphasis on the rediscovery of Greco-Roman culture and texts. An early corpus of travel literature of early modern South India was also produced extensively by the Portuguese, mainly by Catholic missionaries and travellers. ${ }^{94}$ The travel discourse was popular with its contents about exotic geography, monstrous sea animals, multi-headed figures of gods that fed the demands of book market. ${ }^{95}$ Though these were the prominent discourses about India, they did not stand independently but were part of a larger European frame of representing the tropics.

One of the popular themes that was used to represent the Indies was religion. Many Dutch travel accounts written during $16-17^{\text {th }}$ centuries, such as Itinerario: Voyage ofte schipvaert van Jan Huygen van Linschoten (Itinerario: Voyage or Sea Journey of Jan Huigen van Linschoten), De open deure tot

\footnotetext{
92 Donald F. Lach, Asia in the Making of Europe: The Century of Discovery, Vol. I, Book I (Chicago: Chicago University Press, 1993), pp.148-149.

${ }^{93}$ Lach, Asia in the Making, p. 3.

94 Ibid, p.150.

${ }^{5}$ Partha Mitter, Much Maligned Monsters: History of European Reactions to Indian Art (Oxford: Clarendon Press, 1977).
} 
het verborgen heydendom (The open door to the hidden paganism) by Abraham Rogerius and Afgoderye de oost-Indische heydenen (Idolatry of East Indies Heathens) by Philippus Baldaeus, painted vivid pictures of rituals, temples and images of people following non-Christian ways of life. ${ }^{96}$ In his famous work Much Maligned Monsters, Partha Mitter argues that the reaction to Hindu gods demonstrated the clash of two major faiths, Christianity and Hinduism. Mitter states that Christianity was a religion of the book that believed in unity, uniformity and suppression of dissent, the other a form of pluralism that embraced a bewildering (to the European) variety of gods, views and beliefs accumulated over millennia. ${ }^{97}$ The early vision of Malabar in Dutch minds was mostly about the curious religious practices of its inhabitants.

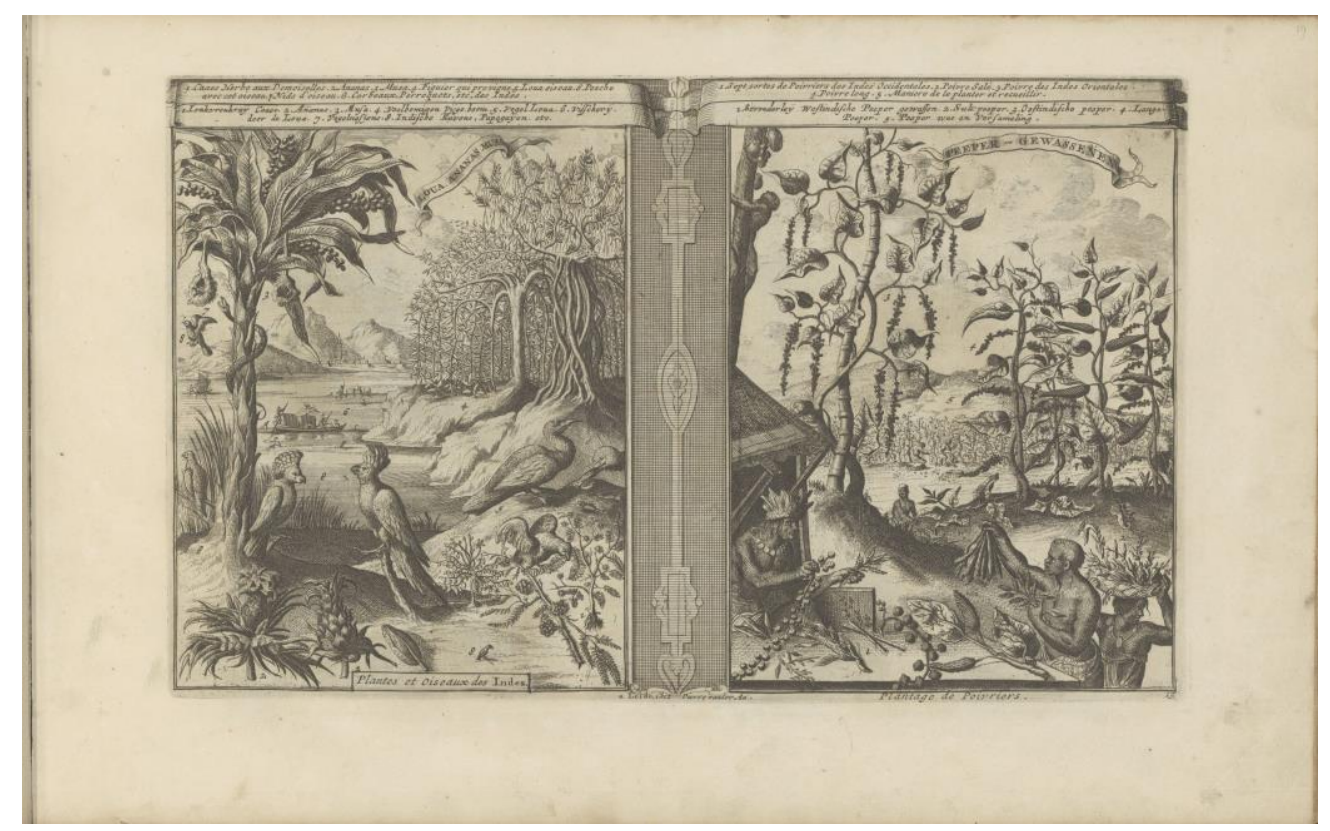

Fig. 4. Pepper plantation from Simon de Vries's travelogue, 1682 (Courtesy: Rijksmuseum Collections)

\footnotetext{
${ }^{96}$ Donald F. Lach, Asia in the Making of Europe: The Century of Discovery, Vol. I, Book III (Chicago: Chicago University Press, 1993), pp. 112-113.

${ }^{97}$ Ibid.
} 


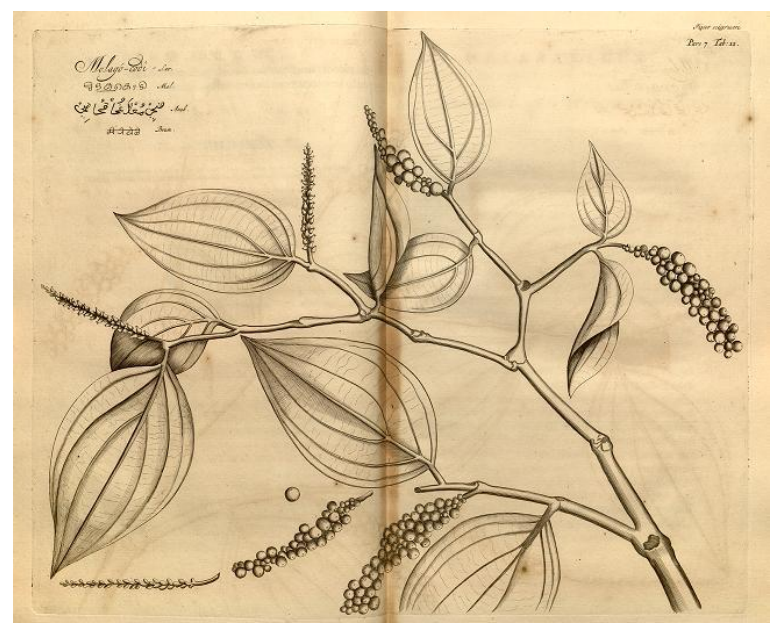

Fig. 5. The engraving of black pepper in the Hortus Malabaricus (Courtesy: Peter H. Raven Library)

Information about Asia in Europe began to improve with greater contact. The seventeenth century saw many publications of Asian geography and a burgeoning book market, filled with ethnographic literature that represented the tropical nature. Nevertheless, pepper or pepper fields were rarely shown. A rare depiction of a pepper field is seen in the first volume of Simon de Vries's popular work on East and West Indies regions, Curious remarks about the most peculiar and surprising things in the East and West Indies, 1682 (see fig 4). ${ }^{98}$ Interestingly, like other illustrations from the work, the images of pepper plants were imaginative representations by the artist, Romeyn de Hooghe. For instance, the illustration shows pepper (marked as East Indies pepper) and chilli peppers (marked as West Indies pepper) in the same frame growing next to each other as big magnified shrubs with large fruits and leaves and some plants even growing as tall as the pictured people.

In reality, black pepper is a flowering vine that grows up to $4 \mathrm{~m}$ in height on supporting trees or poles. It is a spreading vine that roots readily where the trailing stem touches the ground. Here, the author and his artist engaged in a form of knowledge-making by representing the pepper fields and the process of pepper extraction from the vines. The descriptive information was often translated into paintings and pictures by artists who had never seen the Indies. A more realistic representation is found in Volume. 7 of the Hortus Malabaricus (1685) dedicated to climbing shrubs (see fig. 5). ${ }^{99}$ The accompanying description in the Hortus Malabaricus notes that pepper is cultivated

\footnotetext{
98 Simon de Vries, 'Curieuse aenmerckingen der bysonderste Oost en West-Indische verwonderens-waerdige dingen, deel 1, 1682, $\mathrm{p}$. 132 en p. 128'. Object no. 13/14 BI-1972-1043-19. Rijksmuseum Collections, (www.rijksmuseum.nl accessed 23 February 2020). The artist of the illustration is Romeyn de Hooghe, a skilled Dutch Baroque painter, engraver, draughtman and painter of the seventeenth century.

${ }^{99}$ The image of the pepper plant is from the printed Latin version of Adriaan van Rheede, Hortus Malabaricus, Vol 7. Fig. 12, Peter H. Raven Library, Missouri Botanical Garden. (Accessed June 2019). https://www.biodiversitylibrary.org/item/14378\#page/30/mode/1up.
} 
by inserting pieces of the branches into soil. ${ }^{100}$ Though the image is still a decontextualized depiction without supporting trees or location of its growth, it represents a pepper plant in its natural state. This is because, put simply, the description is based on actual observation, rather than being a fanciful depiction. Thus, with the increasing trade in the seventeenth century, more accurate representations based on observation of the tropical environment and goods reached Europe. From the 1650s, pepper became available in larger quantities thanks to the Company's expanding trade in Asia. This meant that it became less of a novelty. Few depictions of pepper appear in Dutch paintings from the 1650 s. ${ }^{101}$

Dutch dramatists of the period also relied on first-hand narratives and travel accounts about the Orient for information and imagery. These first-hand accounts were, in turn, often cumulative works which drew from other sources. An important source was often the official documentation of the principal go-between between the Dutch Republic and Asia in the period, the Dutch East India Company. ${ }^{102}$ The archives of the Company at times constituted the mother narrative of these travelogues, pamphlets, and histories, which entered the Dutch print market and which, on occasions, produced significant contemporary accounts about Asia. This corpus of information was informed by the Company's encounter with Asian polities and was the outcome of complex systems of information procurement and brokerage which involved the participation of multiple agents, both European employees of the Company and local people. 'Owing to their palpable "Oriental" content, natural history works were, consequently, the products of processes of information transfer that originated in the Dutch East India Company's engagement with Asia. ${ }^{103}$ An engagement with the written works produced for the Dutch book market reveals the ideas of 'other' peoples, nature, customs that were co-produced by travellers, artists, engravers, painters, merchants and so forth. ${ }^{104}$ Dutch trade in the east and the emergence of Dutch East India Company thus provided the context for these artistic developments. As Tony Ballantyne notes, in terms of knowledge production, ethnographic literature allowed a population to be surveyed through the identification, description and quantification of various distinctive ethnic, religious and regional groups. Such knowledge facilitated, as Ballantyne notes, 'not only in the construction

\footnotetext{
100 Van Rheede's Hortus Malabaricus, Vol. 3, p.46.

101 Pieter Roelofs, 'Painting Asia: Oriental luxury goods and exotic curiosities in Dutch paintings in Asia' in Asia in Amsterdam, p.232.

102 Manjusha Kuruppath, 'Staging Asia: The Dutch East India Company and the Amsterdam Theatre' PhD Thesis, Leiden University, 2016, pp.16-18.

103 Ibid, p.18.

104 See, Surekha Davies, Renaissance ethnography and the invention of the human: new worlds, maps and monsters (Cambridge: Cambridge University Press, 2016).
} 
of a detailed picture of the contours body politic, but also it allowed potentially rebellious cooperative communities to be singled out'. ${ }^{105}$

\section{Science in the Republic}

The seventeenth-century Republic was in the process of developing a collective identity. The commercial success of the Republic provided the material and financial stability for knowledgemaking enterprises to prosper. Material culture grew with patronage received from the elites, as well as the newly emerging group of scholars who were keen to use the new commodities as a status symbol but also to study them in their university. People took advantage of opportunities for social mobility that opened up in the seventeenth century. In other words, "to show that you were knowledgeable was to show that you were of high status, at least in a community valuing that knowledge". ${ }^{106}$ The divide between arts and science was often blurred. The natural and artificial objects and their images that were brought to the fore by the lively trade represented a sustained mediation between art and nature and the human capability of transcending the boundary between these two domains. Knowledge-making took place both in universities and artisanal workshops. By examining the artisanal practices and skills of goldsmiths, potters and painters of the period, Pamela H. Smith has argued that the Scientific Revolution was less of a theoretical affair, i.e. less about theorizing universal principles of nature, than we tend to think. ${ }^{107}$ The artistic and entrepreneurial culture of the Republic was a stimulus for the experimental philosophy of scientific research in the sixteenth and seventeenth century. Engaging in trade changed the thinking of Dutch citizens, leading to new emphasis on such values such as objectivity, accumulation and description.

\section{Conclusion}

The chapter has examined the primacy of the Dutch East India Company in the Euro-Asian and intra-Asian trade between 1600 and 1800. In the second part of the eighteenth century, the English and the French began to catch up, but it was not until the 1780s that they exceeded the Dutch in the share of outbound tonnage. ${ }^{108}$ The environmental historiography of South Asia has generally focused on the European impact on nature in the colonies, while the changes that were brought

\footnotetext{
105 Tony Ballantyne, 'Empire, Knowledge and Culture: From Proto-Globalization to Modern Globalization' in A. G Hopkins (ed.), Globalization in World History (London: Pimlico, 2002), p.126.

106 Anne Goldgar cited in Catherine S. Abou-Nemeh, 'The Natural Philosopher and the Microscope: Nicolas Hartsoeker Unravels Nature's “Admirable CEconomy”, History of Science, Vol. 51 no. 1, 2013, p.3.

107 Pamela H. Smith, The Body of the Artisan: Art and Experience in the Scientific Revolution (Chicago: The University of Chicago Press, 2012).

108 Zwart, 'Globalization and Colonial Origins', p. 521.
} 
to European knowledge systems through encounters with Asian nature have remained overlooked. An exploration of the seventeenth century spice trade in Malabar allows us to see how significant trade was in bringing people into contact with other peoples, cultures, goods and religions, but also with the environments to which they were unaccustomed. European empires acted as agents of globalization, appropriating new lands and sources of revenue, while moving people, commodities, technologies and ideas from settlements across the globe. Alongside trade, the commercial networks acted as information networks that facilitated a steady flow of information about Asia and Malabar to a Dutch audience ready and willing to consume both goods and information about that region of the world. The encounters facilitated in the knowledge-making of the lands, peoples and their environments for the purpose of control.

Trade bought new and expensive goods that were desired by the burgeoning elite in the Dutch Republic. New regions, commodities in the form of spices, materia medica and other information of Malabar channelled through book markets, expanded the artistic and scientific enquiry of nature. What large quantities of new goods like pepper brought was not only a change in the culinary scene, but also in the artistic and scientific spheres of life. The new trade items such as pepper sparked people's imagination and challenged the artists and philosophers who now had to make sense of the 'new' worldly goods. Artists grappled to present the new challenges to their senses while cartographers tried to map the areas that challenged their earlier understanding of the earth. New acquisitions were added to the repertoire of known knowledge in Europe. This chapter has discussed the political-economic context that supported the development of science in the Republic as well as in its overseas territories. To fully understand the construction and dissemination of knowledge, a detailed analysis of the fundamental structures and the levels at which knowledge was created, consumed and transmitted is required. Thus, the following chapter will explore knowledge-production with regards to medico-botanical texts on the flora of the Indies. 


\section{Chapter Two}

\section{Fashioning Flora: The Hortus Malabaricus and Indigenous Knowledge in Malabar (1678-1693)}

Malabar in the seventeenth century was a conglomeration of people belonging to different castes and different religions such as the Brahmins, Ezhavas, Nairs, St. Thomas Christians, Jews, Muslims, and Europeans. Each of these communities had their own distinct healing and medicinal practices. The tradition of Ayurveda, which is often quoted as the "Indian system of medicine", was prevalent on the coast of Malabar from the eleventh century with the establishment of the Brahmin settlements. ${ }^{1}$ Apart from Ayurveda, other systems of medicine existed in the Malabar coast. Folkloric as well as epigraphical evidence shines light on other medical traditions. The medical traditions in Malabar of Ezhava vaidyam (practiced by the so-called low caste Ezhavas), marmacikitsa, kalari vaidyam and kathakali vaidyam all involved medicine and a strict dietary regime. Tribal medicine, lada vaidyam, was medicine practiced by travelling physicians called lādans belonging to lower caste. Rasavaidya, understood as iatro-chemical medicine, and certain forms of unani medicine were practiced by the Moplah Muslims. All these traditions existed simultaneously in Malabar. The prevalence of multiple forms of traditions within the same region can be attributed to caste and jati (sub-caste) restrictions. Members of lower castes had to obey or, if they were of a higher caste, were freed from obeying a strict dietary restriction (the prohibitions on consumption of meat and certain types of plants, especially tubers), as well as bodily regulations, such as 'untouchability' and 'unapproachability,' practiced in South India from the medieval to the modern period. ${ }^{2}$ It is into this veritable cornucopia of healing traditions that the Europeans dipped their hands during the early period of European expansionism. ${ }^{3}$ These medicinal practitioners were seen as producing vaidyam or medicine and unlike in Europe, their knowledge was not seen as ars in the Malabar context.

With the creation of European settlements, new institutions came into existence. Institutions like leper houses, hospitals and orphanages were started by the Portuguese in the

\footnotetext{
${ }^{1}$ Malavika Binny, 'Plants, Power and Knowledge: An Exploration of the Imperial Networks and the Circuits of Botanical Knowledge and Medical Systems on the Western Coast of India Against the backdrop of European Expansionism', Global Histories, Vol. 1, 2015, p. 13.

2 Binny, 'Plants, Power and Knowledge', p. 15.

${ }^{3}$ Ibid, p.14.
} 
sixteenth century in Malabar. When the VOC took control over the region, some of them were demolished while others were continued. Within Fort Cochin there was a hospital. ${ }^{4}$ Servants from the garrison, artillery and seafarers or sailors of the Company were often admitted to the hospital. The main source of this chapter Hortus Malabaricus, drew from various local and European medicobotanical knowledge systems. In this context, the chapter will probe into the compilation of the Hortus Malabaricus in Malabar where multiple knowledge systems existed. It will argue that colonial knowledge was built upon indigenous knowledge systems that had their own distinctive character.

Around 20kms from Fort Cochin, where the Dutch East India Company made their administrative base in 1663, stands the Hill Palace Museum with a Hortus Malabaricus garden, which houses some of the rare plant species of Kerala mentioned, named after Hortus Malabaricus (or Garden of Malabar), a seventeenth century medico-botanical work. ${ }^{5}$ The Hortus Malabaricus is a 12-volume medico-botanical work on Malabar plants, published in Amsterdam between 1678 and 1693. The materials for the work were compiled by Hendrik Adriaan Van Reede, Dutch Commander of Malabar, 1670-77, with collaborations from a Carmelite priest, Malabar physicians, translators, draughtsmen and artists in Cochin. It was published in Amsterdam, with assistance from Dutch professors and botanists. Just why was a Dutch Commander interested in compiling a medico-botanical work on Malabar flora in the seventeenth century? And, how and why was the work on Malabar botany published in Amsterdam? To answer the above questions, this chapter focuses on the following themes: the culture of collecting naturalia in the Dutch Republic, Dutch bio-prospecting efforts in the Indies, the life of Hendrik Van Reede with the Dutch East India Company and his collaborators, and the concept of indigenous knowledge-systems.

A number of recent publications have highlighted the importance of the Netherlands as a focal point for understanding the emergence of new ideas and practices in the sixteenth and seventeenth centuries. ${ }^{6}$ Scholars, mostly historians, have looked at early modern natural history collections and the production of knowledge in early modern Europe. They have focused specifically on commerce and science, sites of knowledge-production and natural history

\footnotetext{
${ }^{4}$ Anjana Singh, Fort Cochin in Kerala, 1750-1830: The Social Condition of a Dutch Community in an Indian Milieu (Leiden: Brill, 2010), p. 26.

5 'A new Hortus Malaabaricus= Garden of Malabar'; https://hortusmalabaricus.net/new-hortus-malabaricusgardenmalabar; accessed 26 April 2020. The plants are preserved as part of the project of Centre for Heritage Studies sponsored by Kerala State Council for Science, Technology and Environment.

${ }^{6}$ Londa Schiebinger, Plants and Empire: Colonial Bioprospecting in the Atlantic World (Cambridge, Massachusetts: Harvard University Press, 2004); Siegfried Huigen, Jan L.de Jong and Elmer Kolfin (eds.), The Dutch Trading Companies as Knowledge Networks (Leiden: Brill, 2010); Lissa Roberts (ed.), Centres and Cycles of Accumulation in and Around the Netherlands during the Early Modern Period (Münster: LIT Verlag, 2011).
} 
collections of nobles and liefhebbers. ${ }^{7}$ The liefhebber lay at the centre of a vast information network that operated on a local, regional, and global scale. It represented a close-knit community of connoisseurs, naturalists, and traders who shared knowledge and specimens. ${ }^{8}$

The focus on European sites of knowledge-production has produced literature on curiosity cabinets, private and public gardens and the development of anatomical studies. ${ }^{9}$ Though most of the studies have acknowledged circulations of science and knowledge transfers between different sites in Europe, the sites outside Europe are weaved into the European grand narrative of the development of science. These studies have treated sites outside Europe as centres from which knowledge (in terms of specimens and drawings) was collected and then transferred to the main centre in Europe, in which the central activity of knowledge making took place. Thereby, such studies have configured Europe as the centre where diverse knowledge systems merged to form scientia. This, wittingly or otherwise, has echoed older works on the history of colonial science, which by and large emphasised a diffusionist model of science in which European science remained the centre and colonial science the periphery. A reassessment of colonial science suggests that significant intellectual developments, and by extension globalization itself, were driven by changes not just in metropolitan centres, but also distant 'peripheries'. ${ }^{10}$

Historians have regarded European trading networks such as the Dutch and English East India Companies as engines facilitating the transfer of specimens from overseas to Europe. ${ }^{11}$ While the companies did facilitate the movement of plants, animals and other natural specimens, sites outside Europe were not merely fringes in this knowledge-making process. The sites from which the collection and initial drawings were prepared, were also significant sites of knowledgeproduction. They were also regions in which intersection of different epistemologies and multiple knowledge systems merged to produce new knowledge. In this context, this chapter will look at the production of the Hortus Malabaricus in Malabar, more precisely in Cochin, where the Dutch Governor had his residence and a garden. Subsequently, it will examine how the production of the text took place in the Republic.

\footnotetext{
${ }^{7}$ Liefhebbers of nature could be loosely translated as "lovers" of nature. Since the translation does not fully encapsulate the significance of the Dutch term liefhebbers in natural history, the thesis will use the Dutch word.

${ }^{8}$ Pamela Smith, 'A Tulip for a Cup of Tea? Commerce and Nature in the Dutch Golden Age', Annals of Science, Vol. 66, no. 2, 2009, p.270.

${ }^{9}$ Fokko Jan Dijksterhuis and Andreas Weber, 'The Netherlands as A Laboratory of Knowing in Dutch Contexts' in Fokko Jan Dijksterhuis, Andreas Weber and H. J. Zuidervaart (eds.), Locations of Knowledge in Dutch Contexts (Leiden and Boston: Brill, 2019), p.20.

10 Tony Ballantyne, 'Empire, Knowledge and Culture: From Proto-Globalization to Modern Globalization' in A. G Hopkins (ed.), Globalization in World History (London: Pimlico, 2002), p.133.

${ }^{11}$ Matthew Sargent, 'Recentering centers of calculation: Reconfiguring knowledge networks within global empires of trade' in Paula Findlen (ed.), Empires of Knowledge: Scientific Networks in the Early Modern World (Oxford: Routledge, 2018), p.299.
} 
By building on an impressive body of literature on knowledge-production that has developed in the last few years, this chapter is an attempt to locate the Hortus Malabaricus in the growing literature of medical and botanical knowledge networks. ${ }^{12}$ In examining the text and its creation, this chapter seeks to analyse how local knowledge was collected, documented and transmitted to European botanical and scientific networks. While literature on the Hortus Malabaricus exists, ${ }^{13}$ its development from manuscript to printed work needs examination, as also do the people who were involved in the process. For facilitating this, the chapter will examine the Hortus Malabaricus as a boundary object, the production of which involved the cooperation of multiple actors having similar or conflicting interests. ${ }^{14}$ As Susan Leigh Star and James R. Griesemer note, a boundary object is a scientific work that is heterogenous, one that is created by participants from several distinct social worlds, including those of scientists, amateur naturalists, patrons, hired hands and administrators. To create a scientific work, boundary objects had to be designed to allow translation and standardisation for different groups. The meaning of natural history objects and specimens changes with movement, and according to different social and cultural contexts. The historiography of the Hortus Malabaricus and other medico-botanical treatises of the period often treats texts as static objects with a fixed textual and historical value. This chapter aims to present the Hortus Malabaricus as an evolving intellectual enterprise that developed alongside the expansion of the VOC in Malabar.

By stressing the politics of knowledge-making, the chapter will argue that the Hortus Malabaricus is a transnational and transcultural exercise in science that reflects the fluidity of early modern scientific and intellectual traditions. Indian historian of science, Kapil Raj argues that the production of the Hortus Malabaricus shows the short and long ranging knowledge circulations, intercultural interactions and connections involved in its making. ${ }^{15}$ This chapter will further this framework to highlight the role played by patronage in the making of knowledge. Its development,

\footnotetext{
12 Richard Grove, Green Imperialism: Colonial Expansion, Tropical Island Edens and the Origins of Environmentalism, 1600-1860 (Cambridge: Cambridge University Press, 1995); Richard Drayton, Nature's Government: Science, Imperial Britain and the 'Improvement' of the World (Yale: Yale University Press, 2000); Vinita Damodaran, Anna Winterbottom and Alan Lester (eds.), The East India Company and the Natural World (London: Palgrave Macmillan, 2015); Ines G. Županov and Ângela Barreto Xavier, 'Quest for Permanence in the Tropics: Portuguese Bio prospecting in Asia (16th18th Centuries)', Journal of the Economic and Social History of the Orient Vol. 57, 2014, pp.511- 548; and Yota Batsaki, Sarah Burke Cahalan and Anatole Tchikine (eds.), The Botany of Empire in the Long Eighteenth Century (Washington: Dumbarton Oaks Research Library and Collection Washington D.C, 2016) among others.

${ }^{13}$ The earliest studies were done by J. Heninger, Richard Grove and K. S. Manilal. J. Heninger, Hendrik Adriaan van Reede tot Drakenstein (1636-1691) and Hortus Malabaricus: A contribution to the bistory of Dutch colonial botany (Rotterdam and Boston: A. A. Balkema, 1986); K. S. Manilal, Botany and History of the Hortus Malabaricus (Rotterdam and New Delhi: A. A. Balkema and Oxford IBH, 1980).

${ }^{14}$ Susan Leigh Star and James R. Griesemer's, 'Institutional Ecology, “Translations” and Boundary Objects: Amateurs and Professionals in Berkeley's Museum of Vertebrate Zoology, 1907-39', Social Studies of Science, Vol. 19, no. 3, Aug. 1989, p.413.

15 Kapil Raj, 'Thinking Without the Scientific Revolution: Global Interactions and the Construction of Knowledge', Journal of Early Modern History, Vol. 21, 2017, pp.445-458.
} 
this thesis argues, also reflects the global nature of scientific activity in the seventeenth century, a novel development in world history. Van Reede's career and journeys across the trading posts of the Company will set the geographic scope of this study. ${ }^{16}$ To examine the Dutch India Company's medical and botanical knowledge-making endeavours in the Indies, it is necessary to examine the development of natural history, medicine and botany in Europe.

\section{Collecting Nature in a Republic of Curiosity}

Natural history collecting, printing and publishing, as well as buying and selling, all took place in the broader context of colonial expansion, commercial exchange, and self-fashioning. As discussed in the first chapter, collecting had become a fashionable elite activity in the seventeenth century, not just in Europe, but other cultures as well. By the end of his reign, the Mughal emperor Akbar (1556-1605) had amassed an astounding collection of Renaissance visual and literary artefacts that included a vast number of engravings of the works of artists ranging from Michelangelo, Raphael, and Taddeo Zuccaro and oil paintings donated by aristocratic families in Rome. ${ }^{17}$ Art historian Craig Clunas argues that the material and consumption culture of elites in Ming China in the sixteenth and seventeenth centuries was similar to Europe. He examines early modern Chinese literature that refers to monthly markets at the rear gate of the palace of the Ming emperors that sold 'curious precious or rare treasures such as Xuande bronzes and Chenghua porcelain'. ${ }^{18}$

In Europe, collections ranged from plant and animal specimens, shells, porcelain and so forth. In this culture of collecting, there existed networks of people involved in buying and selling items from distant places. The Dutch trade facilitated movement of different materials of a nature that were earlier not available for purchase. From the sixteenth century onwards, curiosity cabinets were no longer only for aristocrats or kings, and were owned by members of the nascent middleclass professional groups. These were chiefly medical men, pharmacists and merchant classes, who collected mainly, but by no means exclusively, plants ('simples' or medicinal herbs) for medicinal purposes. By the late seventeenth and eighteenth centuries, cabinets put together by professionals and professors of natural history, physicians and pharmacists for scientific study became the norm. Exotic collectibles such as true balsam from the East, and New World cinnamon, which Columbus

\footnotetext{
${ }^{16}$ This approach is inspired by Susan Leigh Star's and James R. Griesemer's formulation of 'boundary object' in, Star and Grisemer, 'Institutional Ecology, Translations and Boundary Objects', pp.387-420. A boundary object is formulated as a scientific work that is heterogenous and one that involves participants from several distinct social worlds, including those of professional scientists, amateur naturalists, patrons, hired hands and administrators. For creating a scientific work, boundary objects had to be designed to allow translation and standardization among different groups.

17 Sanjay Subrahmanyam, 'A Roomful of Mirrors: The Artful Embrace of Mughals and Franks, 1550-1700', Ars Orientalis, Vol. 39, 2010, p. 41.

${ }_{18}$ Craig Clunas, Superfluous Things: Material Culture and Social Status in Early Modern China (Oxford: Polity Press, 1991), p.137.
} 
identified in 1492 as a potential commodity for his Spanish patrons, were essential ingredients in early modern pharmacopeia. Apothecaries displayed them in rooms above shops on the ground floor, as a means of further reassuring customers that their medicines were derived from a profound knowledge of the natural world. ${ }^{19}$ Herbarium materials, such as dried plants, played a role in the economy of exchange of early modern natural history. ${ }^{20}$

Cashing in the need for rare and curious things of nature, merchants and naturalists produced illustrative works on rare plants and species of distant places. The natural history writers presented their work as producing 'new' knowledge in Europe. Dedicating Volume 7 of the Hortus Malabaricus to Hendricus Jacobas (Lord of Zuilen), Van Reede wrote, 'it is refreshing for the eyes to observe the collection and contemplate how vast admirable are the works of the Creator, how ignorant we are of the innumerable things which are found elsewhere on the globe.. ${ }^{21}$ Many individuals in sixteenth- and seventeenth-century Europe were engaged both in commerce and the pursuit of natural knowledge, and their scientific ideas and practices had clear and measurable economic value that could be offered to the market. ${ }^{22}$ Adding valuable plant collections to the cabinet of curiosities could aid in moving up the social ladder in the burgher society. A fine example is John Hudde (1628-1704), Director of the VOC since 1679 and renowned mathematician of the period. Hudde was engaged in the pursuit of experiential knowledge. He used the information from the clocks of Christiaan Huygens and tested it in measuring longitude at sea on a voyage of the Company ship to the Cape of Good Hope. At the same time, he was also a powerful burgomeester with major commercial interests. His statistical expertise predicted a shortage of pepper as a commodity in the European markets in the 1690s, a prediction which turned out to be correct. ${ }^{23}$ This new culture of empiricism that valued experience was consonant with the values embedded in commerce. Merchants-particularly medical practitioners-took a deep interest in natural facts, including bodily experiences of viewing, sensing and owning exotic collectibles.

If we look at plants alone, we find a vast commerce in the ideas, presentation, application and testing of them: for example, herbaria, were collections of dried plants pasted on paper and bound together in books, and herbals or illustrated catalogues of plants that arranged them in some

\footnotetext{
19 Paula Findlen, 'Anatomy Theaters, Botanical Gardens, and Natural History Collections' in Katherine Park \& Lorraine Daston (eds.), The Cambridge History of Science (Cambridge: Cambridge University Press, 2006), p.287.

${ }^{20}$ Brian W. Ogilvie, The Science of Describing: Natural History in Renaissance Europe (Chicago and London: The University of Chicago Press, 2006), p.171.

${ }^{21}$ Van Rheede's Hortus Malabaricus English Edition with Annotations and Modern Botanical Nomenclature, Vol. 7, by K. S. Manilal (Thiruvananthapuram: University of Kerala Press, 2003).

22 Pamela H. Smith and Paula Findlen (eds.), Merchants and Marvels: Commerce, Science and Art in Early Modern Europe (London and New York: Routledge, 2002), p.17.

${ }^{23}$ Femme S. Gaastra, 'The Dutch East India Company: A Reluctant Discoverer', The Great Circle, Vol. 19, no.2, 1997, p.113.
} 
order. Plant specimens could often be found in curiosity cabinets. Gardens, herbaria and cabinets were more sites for cataloguing nature. Medicine and natural history emerged as popular and profitable sciences of the early period not only in the Republic, but also throughout Europe. From local physicians, Jesuit missionaries to Company bureaucrats, a multitude of people were engaged in the collection and commodification of nature. Missionaries added a new dimension to bioprospecting alongside their spiritual methods of healing. ${ }^{24}$ For instance, the early Protestant missionaries such as Bartholomaus Ziegenbalg and Heinrich Plütschau, who worked in the Danish settlement of Tranquebar, closely associated themselves with local customs and traditions. Plütschau wrote about Indian medical practitioners as having their own "search into the secrets of nature" and how their medical skills could surprise physicians in Europe: "our physicians in Europe would wonder at the Performance of our Malabar Doctors here". 25

Medical practitioners were crucial in formulating, articulating and disseminating this new philosophy of nature. Medicine always had some manual component to it, and physicians were always involved in the preparation of medicaments, combining theory and practice in a way that would eventually characterize all natural philosophical activity. More than that, too, physicians were taught about the properties of various plants as well as the manner in which environments could both cure and cause disease, thanks to a renaissance in the humoural ideas of illness. The ancient Greek medicinal tradition saw a doctor's role as to combating disease or to helping nature to do so. ${ }^{26}$ Medicine was thus, sometimes included in the study of nature and could be investigated by men who styled themselves as philosophers rather than doctors. ${ }^{27}$ Moreover, apothecaries and herbalists had long claimed direct access to nature and were among the first to concern themselves with the relationship between word, image and nature in herbals and other texts. ${ }^{28}$ Tropical medicines were highly valued for treating the Company personnel in the Indies and for export in the form of balms, oils and substances for preparing decoctions for apothecaries in the Republic. Thus, the people working for the Company- merchants, missionaries, amateur botanists and naturalists- were involved in the knowledge-making process.

\footnotetext{
${ }^{24}$ Bioprospecting can be broadly defined as the activities undertaken by the European trading companies to collect and compile medico-botanical knowledge in the overseas settlements. Londa Schiebinger, Plants and Empire: Colonial Bioprospecting in the Atlantic World (Cambridge, Massachusetts: Harvard University Press, 2004), p.5.

25 Pratik Chakrabarti, Medicine and empire, 1600-1960 (London: Palgrave Macmillan, 2014), p. 27.

${ }^{26}$ G.E.R. Lloyd, 'Introduction', in G.E.R Llyod (eds. and intro), J. Chadwick and W.N. Mann (trans.), Hippocratic Writings (London: Penguin, 1983 Reprint), p.22.

27 Ibid, p.39-40.

28 Smith and Findlen, Merchants and Marvels, p.17.
} 


\section{Early European Bioprospecting in the East Indies}

Any attempt to single out the Dutch medico-botanical networks in Malabar will only reveal half of the story. The search for tropical medicinal plants had already begun during the Portuguese period in Asia in the $15^{\text {th }}$ century. As discussed in Chapter One, Portuguese presence along the southwest coast was strong before the Dutch overthrew their monopoly in trade. The Portuguese -imperial officials, missionaries, and the people connected with them, all living and working under the banner of the Portuguese empire - were interested in gathering medicinal knowledge. The results of their endeavours were relevant for the development of natural history, as they were important actors within the broader community of naturalists. ${ }^{29}$ Historians Ines Zupanov and Angelo Xavier argue that botany and pharmacology were of vital concern to the Portuguese empire. $^{30}$ The production of bio-knowledge by Portuguese naturalists Garcia de Orta and Cristóvão da Costa, for example, was well under way before the Dutch bioprospecting in the East Indies began. ${ }^{31}$

Garcia de Orta published his Colloquies on the Simples and Drugs of India (Colóquios dos simples e 52 erb a he cousas medicinais da India) in Goa in $1563 .{ }^{32}$ Costa's work, Treatise of Drugs and Remedies of the East Indies, with their Plants Drawn from Life (Tractado de las 52 erb a y medicinas de las Indias orientales), appeared in Burgos in 1578. Both of these works stand out as early modern compilations of natural histories and the printed works on medicinal plants, although, Zupanov argues, the detailed knowledge of plants and remedies that Orta displayed in fifty-nine chapters was not unfamiliar to the experienced Portuguese merchants, apothecaries and physicians in Europe. ${ }^{33}$ Besides medicinal plants, Orta also mentioned other critical economic plants, such as sandalwood and champi, used in making scents and perfumes. ${ }^{34}$ The cognitive practice of direct observation gained currency through his work. Orta's work acquired fame in Europe after Cristóvão da Costa used it as a reference for his work, Treatise of Drugs and Remedies. Besides Costa's Treatise, Flemish botanist, Carolus Clusius (Charles de l'Ecluse) translated Orta's Colloquies into Latin and published it in an illustrated volume, entitled Aromatum et simplicium aliquot medicamentorum apud Indos nascentium historia (Antwerp, 1567) that went through several editions. ${ }^{35}$ The Colloquies remains a pioneering work, as

\footnotetext{
${ }^{29}$ Ines G. Zupanov and Angela Barreto Xavier, 'Quest for Permanence in the Tropics: Portuguese Bioprospecting in Asia (16-18 $8^{\text {th }}$ centuries)', Journal of the Economic and Social History of the Orient, Vol. 57, 2014, p.511.

${ }^{30} \mathrm{Ibid}$, See footnote, 1, p.512.

${ }^{31}$ Cristóvão da Costa (1501-1568) was a Spanish-trained physician working for the Portuguese in India.

${ }^{32}$ Garcia de Orta's book is in the form of a dialogue between Orta and an imaginary character Ruano, a newly arrived Portuguese physician and their discussion includes medicines, edibles and novelties from the west coast of India.

33 Zupanov and Xavier, 'Quest for Permanence', p.519

${ }^{34}$ R. N. Kapil and A. K. Bhatnagar, 'Portuguese Contributions to Indian Botany', Isis, Vol. 67, no. 3, September 1976, p.451.

35 See, Zupanov and Xavier, 'Quest for Permanence', p.525.
} 
it was the first secular book printed in Goa among many works of political and military interests. Historian Richard Grove suggests that Orta's work was Europe's first print encounter with tropical botany that led to the diffusion of Indian medico-botanical knowledge to more extensive European medical and commercial networks. ${ }^{36}$ Thus, natural history works created under the Dutch Company in Asia were built upon the knowledge generated by half a century of intense Portuguese trade in Asian spices, plants and medicines. The early Portuguese and Dutch explorations of native flora were well entrenched in the European classificatory systems, medical training and recipes by the middle of the eighteenth century. ${ }^{37}$

\section{Dutch Bioprospecting in Asia}

On 24 April 1669, Andries Cleyer, physician and botanist at the castle of Batavia, sent a letter from the Government of Batavia (the headquarters of the Dutch East Indies in Asia) was sent to Ceylon (a major Company settlement) that read: "thus we shall be greatly pleased if you would recommend Dr. Robertus Padbrugge (whom we take to be also a good herbalist) as well as the master surgeons and others who have knowledge of medicinal herbs to speculate and satisfy their curiosity about these things to discover in Ceylon all that might be found to be a great comfort there". ${ }^{38}$ This letter could possibly be interpreted as an official Dutch call for the search for medicinal plants in the Indies, or 'bio-prospecting'. Cleyer had learned about the medicinal plants of Ceylon and had intended to receive them so that the Company could stop importing medications from the Netherlands. Cleyer was a German-born physician and botanist who was in the service of the Company since 1662 until his death in 1697-98. ${ }^{39}$ He started his career as a supervisor for the Dutch in Deshima, Japan, where he illegally accumulated plants and had close correspondence with the scholars of the Botanical Garden in Leiden, Dutch Republic. ${ }^{40}$ In the castle of Batavia there existed a surgeon's shop that dealt with requests from the trading stations for medicaments. Requests were made to Amsterdam to refill the stocks to be sent to Asia. The management of the shop was entrusted to a senior surgeon, who also ran a siekenhuis (hospital) and trained surgeon's

\footnotetext{
36 Richard Grove, 'Indigenous Knowledge and the Significance of South-West India for Portuguese and Dutch Constructions of Tropical Nature', Modern Asian Studies, Vol. 30, no. 1, February 1996, p.125.

${ }^{37}$ Chakrabarti, Medicine and Empire, p. 23.

${ }^{38}$ Heninger, Hendrik, Adriaan Van Reede, p.29.

39 Alette Fleisher, 'Breyne's Botany: (Re-)locating Nature and Knowledge in Danzig (circa 1660-1730)' in Fokko Jan Dijksterhuis, Andreas Weber and H. J. Zuidervaart (eds.), Locations of Knowledge in Dutch Contexts (Leiden and Boston: Brill, 2019), p.128. A Company record from January 17, 1700 shows that a contract was drawn again in 1700 with Cleyer, so the year of his death might be two years later. Contract of Andries Cleyer, Batavia, 1700, Realia, File no: 916, Arsip Nasional Republik Indonesia (hereafter ANR), accessed 11 May 2020. The Realia were compiled in the eighteenth-century as a repertoire (or subject directory) of more than 2,050 subjects including 47,500 references to government deliberations or decisions. (See, https://sejarah-nusantara.anri.go.id/realia/).

${ }^{40}$ Fleischer, 'Breyne’s Botany', p.128.
} 
apprentices. ${ }^{41}$ In 1676, chief surgeon Cleyer had also concluded a profitable contract with the Company for the supply of medicaments, which enabled him to engage privately with practitioners of natural history like Hendrik Claudius, Cornelis Abrahmsen and George Mesiter (an experienced gardener) in the Indies and in the republic. ${ }^{42}$ Three years prior to the call for the search for medicines in Ceylon, Cleyer had reported (on 13 December 1665) that the Chinese medicines imported by the Company were more expensive than the ones imported from the Republic. ${ }^{43} \mathrm{~A}$ report from 1667 describes the conditions for making and supplying Chinese medicines, thereby indicating the Company's attempts in preparing medicines to reduce their dependency on the imports from China. ${ }^{44}$ Similar letters for medicinal plants were also written from Batavia to the governments of Coromandel and Bengal. ${ }^{45}$ Thus, Cleyer was trying to diversify the areas from where medicines could be procured by the Company to reduce the dependency on East Asian medicines to treat the VOC officials in Batavia.

The VOC overseas outposts in Malabar, Batavia and Makassar played an important role in this knowledge circulation, because these posts were not just extensions of Europe, but sites of prolonged encounters with Asian people, and their culture and knowledge-systems. The Company trade also facilitated botanical activities in other parts of Asia. Paul Hermann (1646-95), a German botanist employed as a surgeon, spent several years exploring the flora of Ceylon. His notes were edited by William Sherard (1659-1728) and published as Musaeum Zeylanicum. Paul Hermann is also mentioned in the third volume of the Hortus Malabaricus as having visited Cochin in 1674, though Van Reede writes that he could not contribute substantially to the work. ${ }^{46}$ Hermann's botanical collection passed into the possession of Danish Apothecary Royal August Gunther. Gunther then loaned it to Carolus Linnaeus, who in turn used it in his Flora Zeylanica in 1747. ${ }^{47}$ The correspondence networks of naturalists, botanists and physicians were crucial for the transfer of specimens, texts and drawings.

What differentiates the Hortus Malabaricus from its Portuguese predecessors discussed earlier is the Company framework in which it was developed. While Orta and Costa were physicians to the Portuguese viceroy, Van Reede was as a Governor in Malabar and benefitted from the other official posts held under the Company to create a network of naturalists in the Indies. While Orta's

\footnotetext{
${ }^{41}$ Heninger, Hendrik Adriaan Van Reede, pp.11-12.

42 The contract with surgeon Cleyer was renewed again in 1682. Contracten met Andires Cleyer, Batavia, 1682, File 895, Identification No: ID-ANRI_K66A_EN, folios 406-411, Archives of the Governor-General and Councilors of the Indies, ANRI, accessed 11 May 2020.

${ }^{43}$ Chineese Medicamenten, 13 Dec 1665, Realia 1610-1808, ANRI, accessed 15 January 2020.

${ }^{44}$ Realia file no. 868, pp. 84-86, ANRI.

${ }^{45}$ Heninger, Hendrik Adriaan Van Reede, p.29

${ }^{46}$ Van Rheede's Hortus Malabaricus, Vol. 3, p.xv.

${ }^{47}$ Chakrabarti, Medicine and Empire, p.41.
} 
work was published in Goa, Van Reede carried the drawings and manuscripts he compiled to the Republic for patronage. To understand the geographical journey that shaped the Hortus Malabaricus, it is essential to know the profile of its compiler, Van Reede.

\section{Hendrik Van Reede and the Dutch East India Company}

Hendrik Adriaan van Reede tot Drakenstein (1637-1691), son of Ernst van Reede and Elisabeth van Utenhove, was born in the province of Utrecht in early 1637. When he was fourteen years old, he left the parental home and joined as a soldier in the service of the Dutch East India Company. ${ }^{48}$ He worked under Rijklof van Goens during the siege of Fort Cochin from the Portuguese in 1663 and then became the Commander of Malabar in 1670. He is most famous for having composed a treatise on the flora of Malabar, published under the Latin title Hortus Indicus Malabaricus, Continens Rgeni Malabarici apud Indos celeberrimi omnis generis Plantas rariores. ${ }^{49}$ The work contains information about 725 Malabar plants engraved in 791 copperplate engravings. During a career of thirty-years, he rose from the position of a simple midshipman to that of the commanding commissioner general of the Western Quarters of Asia. He is often mentioned with other contemporaries and fellow Company servants, Paul Hermann and the Ambon naturalist, Georg Everhard Rumphius. However, what differentiates Van Reede here is his expertise as an administrator rather than as a botanist. ${ }^{50}$ Van Reede wrote in the preface to volume 3 of the Hortus Malabaricus, possibly pro forma:

I do not excel either in varied and profound learning or in accurate knowledge of botany, spices and simple medicaments. I should think that anyone who attains to such knowledge ought to apply himself diligently to this one discipline all the days of his life. ${ }^{51}$

Van Reede's first voyage to the East began when he was called to the Cape of Good Hope in 1657 to be part of the fleet of Van Goens, who had an ambitious plan of defeating the Portuguese in Ceylon and India subsequently. The Cape had been a Dutch settlement since 1652 and served as a re-victualling station on the long voyage to the East Indies. There, Van Reede first

\footnotetext{
48 A.J. van der Aa, Biographisch woordenboek der Nederlanden. Deel 16 (Haarlem: J. J. Van Beedeeode, 1874).

${ }^{49}$ Three editions of the Hortus Malabaricus are known: the first Latin edition in folio consisting of 12 volumes published between 1678 and 1693; a second folio edition of volume 1 and 2 in Dutch published as Malabaarse Kruidhof, translated by Abraham van Poot in 1686 and; a Latin edition of volume 1, Hortici Malabarici Pars Prima edited and annotated by John Hill and published in London in 1774. Here, the chapter is concerned with the first edition of the Hortus Malabaricus.

${ }^{50}$ Grove, Green Imperialism, p.85.

${ }^{51}$ Van Rheede's Hortus Malabaricus, Vol. 3, p. ix.
} 
encountered a Company garden, stocked with vegetables and fruits for visiting crew and as a remedy for scurvy which many crew faced on long sea voyages. Heninger demonstrates that Reede's Cape visit was crucial, as he made contact with people who later became influential in producing the Hortus Malabaricus. Of interest in particular, was his friendship with Joan Bax, whose uncle was Joan Huydecoper van Meerseveen, the burgomaster of Amsterdam and one of the directors of the East India Company. Huydecoper was a collector of Asian rarities and also the first Co-Director of the Amsterdam Botanical Garden with Jan Commelin (which is detailed in the next chapter). Jan Commelin was also the editor of the volumes (2-12) of the Hortus Malabaricus. ${ }^{52}$ The role of Huydecoper and Commelin in the development of Amsterdam Botanical Garden will be discussed in detail in the next chapter.

After his stay at the Cape, Van Reede sailed to Batavia in 1657, but there are no significant references to his life in Batavia. Heninger argues that 'the records of the East India Company from this period contain hardly any biographical data about soldiers below the rank of officers. ${ }^{53}$ What we do know is that Van Reede was part of the military expeditions organized by Rijklof van Goens to oust the Portuguese in Malabar. In 1662, Reede was posted as a provisional captain of the conquered Malabar fortresses of Cranganore and Quilon. From 1670, when Malabar became a separate command from Ceylon, Van Reede served as the Commander of Malabar from 1670 to 1677. In Malabar, Van Reede oversaw administration, trade, militia, judicial and religious affairs. Jos Gommans argues that Van Reede was one of the very few intellectuals ever to have graced the overseas administration of the VOC. Van Reede believed that it was essential to have a profound knowledge of local customs, weaknesses and powers to set up a good government. He assessed the political power structure in Malabar as "certainly not a monarchy under one ruler, nor was it a Republic, nor indeed a democracy, because neither the king, nor the aristocracy, nor the majority of the people display the greatest power, but they do so as a whole". ${ }^{54}$ Though there are no official records on the search for medicinal plants in Malabar, Van Reede seems to have taken a personal interest in researching native flora. An indication of this interest is that while residing in Kochi, Van Reede organized the construction of the Company Gardens close to the Dutch fort. ${ }^{55}$ Van Reede set up a laboratory at his residence in Cochin, where he was accompanied by

\footnotetext{
${ }^{52}$ Heninger, Hendrik Adriaan Van Reede, pp.9-10.

53 Ibid, p. 10 .

54 Jos Gommans, 'South Asian Cosmopolitanism and the Dutch Microcosmos in Seventeenth-Century Cochin (Kerala)' in Catia Antunes and Jos Gommans (eds.), Exploring the Dutch Empire: Agents, Networks and Institutions, 1600 2000 (London: Bloomsbury, 2015), p.17.

55 The map from Van Leupe Collections, National Archives, The Hague (hereafter NA) (896) shows a garden close to the residence of the Commander. The garden, which is referred to in Van Reede's Memorandum of 1677, can be recognized on the map by the row of trees behind the buildings. See, Hugo, K. s' Jacob, s', De Nederlanders in Kerala 1663-1701: De memories en instructies betreffende het commandement Malabar van de Verenigde Oost-Indische Compagnie ('sGravenhage: Martinus Nijhoff, 1976): pp.82-85.
} 
chemist Paulus Meysner in his activities. ${ }^{56}$ Heninger quotes Van Reede as having written about "the distillation of oil from roots of wild cinnamon in his laboratory and used with favourable results in the Dutch hospital in Cochin". ${ }^{57}$ There is no further information about his experiments.

The botanical investigation of Malabar flora was Van Reede's independent initiative, and I was not able to find any correspondence between him and the High Commission regarding any botanical expeditions in Malabar. Possibly this was because attempts to conduct experiments on Malabar medicinal plants for immediate use proved more complicated than expected. Reede's efforts were not supported by the government officials at Batavia; instead he was ordered to stop the functioning of the laboratory and the distillery. Interestingly, the High Government accorded permission for setting up a laboratory in Batavia under physician Andries Cleyer. In a letter (1679) to Lords XVII, Cleyer wrote: "here ( in Batavia) a laboratory has also been found, in which by....Grimm (physician) many medicaments are prepared and of which many are found in the forests and gardens of Batavia itself'. ${ }^{58}$ In the year 1677 (when Van Reede was called back from Malabar by the Batavia Council), Grimm requested, under the instructions of Van Goens, consent for setting up a laboratory in Ceylon for the rest of India. In his letter he wrote, 'I can testify that I have never beheld a more suitable place for this [laboratory] in the face of the earth [Ceylon]. ${ }^{.59}$

Though Van Reede held powerful position as a Commander in Malabar, Van Reede lacked patronage to continue his scientific activities. One of the main reasons was his political tiff with Van Goens, who held prominent positions in the Indies and had contacts with some of the highest Dutch officials in Asia. Ever since Malabar was separated from Ceylon to form a separate Command, Van Reede and Van Goens fought to promote their settlements in Malabar and Ceylon respectively. While Van Goens tried to project Ceylon as the prime centre of cinnamon trade, Van Reede sought to present the Malabar flora and its botanical wealth of the region as crucial for the Company. The tensions between the two officers were explicit when Van Goens reacted to the publication of the first volume of the Hortus Malabaricus. He wrote scathingly, 'the book you have sent to us, called Hortus Malabaricus, does not contain anything that is unknown and plentifully to be obtained in Ceylon, so that one need not go to Malabar for this at all. Those who know both maintain that the herbs and medicines in Ceylon are as much more potent as Ceylon cinnamon

\footnotetext{
${ }^{56}$ Ray Desmond, Great Natural History Books and their Creators (London: The British Library and Oak Knoll Press, 2003), p.39.

${ }^{57}$ Heninger, Hendrik Adriaan Van Reede, p.38. I haven't been able to trace the record that Heninger used for this argument. Interestingly, Van Reede talks about cinnamon experiments here. Cinnamon was abundant in Ceylon, and Van Reede probably wished to extract oil from cinnamon to be send to Amsterdam and thus refocus centre of cinnamon trade from Ceylon to Malabar.

${ }^{58}$ Heninger, Hendrik Adriaan Van Reede, p. 53.

${ }^{59} \mathrm{Ibid}$, p. 54.
} 
exceeds wild Malabar cinnamon. ${ }^{60}$ What should be inferred from these Company activities is that early modern botanical networks existed across the trading posts of the VOC, yet worked alongside (and sometimes against) Company politics. The Company placed its commercial interests over botanical interests in Malabar.

\section{Knowledge-Making in Malabar, 1670-1677}

The impetus behind compiling the Hortus Malabaricus seems to have been multi-faceted. There were practical reasons behind the search for tropical herbs. Notably, reasons included the inefficacy of western medicine in tropical climates, the perishability of drugs in warmer and sunnier terrains and, in some cases, the contact with new types of diseases. The drugs imported from Holland often lost their potency over the long sea voyages.

The starting point of the Hortus Malabaricus is a draft on Malabar plants, Viridarium Orientale, prepared by Matteo di San Giuseppe (also referred as Mathew of St. Joseph), a Carmelite priest in Cochin. ${ }^{61}$ The work is considered to have inspired Van Reede to start collecting information on Malabar medicinal plants. However, none of the volumes gives any reference to this work. Instead, Matthew is credited for his assistance to the initial sketches prepared by Van Reede. In the preface to volume 3, Van Reede writes,

"the first sketches of the Hortus were from the first sketches of plants, copied on paper, from there, arose a more accurate delineation of them with the care of rev. Father Matthew, who was relying solely on memory". ${ }^{62}$

Van Reede regarded Matthew's contribution as only an aide-de-memoire, compared with the Dutch contribution. ${ }^{63}$ Even before the Dutch capture of Cochin in 1663, Matthew had written to Leiden mathematician and Orientalist, Jacob van Gool, requesting to publish his notes and drawings of Asian plants. Van Gool came on board and persuaded Lords XVII in 1663 to provide

\footnotetext{
${ }^{60}$ Ibid, p. 61.

${ }^{61}$ The name of the manuscript is nowhere referred to in any of the 12 volumes of the Hortus Malabaricus.

${ }^{62} V$ an Rheede's Hortus Malabaricus, Vol. 3, p. xiv.

63 Pietro Foglia alias Matteo di San Giuseppe studied medicine in Naples and entered the Carmelite Order in 1639. He travelled extensively through the Middle East before being sent to the Malabar mission where he died in 1691. The manuscript of the Viridarium Orientale in the Biblioteca Nazionale Centrale in Rome was described in the catalogue, until just a few years ago, as a 'spiritual' treatise. See the discussion of Matteo's work in Zupanov and Xavier, 'Quest for Permanence', p.533.
} 
for the transport of Matthew's manuscripts to the Netherlands. However, after the conquest of Cochin by the Dutch, Matthew's bishop, Giuseppe di S. Maria, decided to take his manuscripts to Rome instead of the Netherlands. ${ }^{64}$ Art historian Sita Reddy argues that many of the plant drawings found in a copy of the Hortus Malabaricus in the British Library are thus mis-attributed to Matthew. ${ }^{65}$ I think the confusion is resulted from the insufficient information regarding the manuscript copies that reached Europe in different years.

Dutch historians have focused on the Dutch contributions in the making of the Hortus Malabaricus. Zupanov and Xavier argue that the reason behind the historical omission of Catholic efforts at bioprospecting lies in the construction of Indian colonial and postcolonial historiography, mainly in a Protestant intellectual framework, which perceives Catholic missionaries as indifferent, if not opposed, to 'scientific' projects and knowledge. ${ }^{66}$ Zupanov argues that the reason for a Dutch-Portuguese collaboration in Cochin was a direct result of the simmering hostility between the Portuguese 59erb aqu institutions and the Roman Propaganda Fide. ${ }^{67}$ For his help in preparing the initial draft of the Hortus Malabaricus, Matthew earned protection from the Dutch and even acquired land to build a church in Chethiah, near Cochin. As for the Dutch, who had made it a rule not to allow Catholic priests of Portuguese origin to practice in the region, collaboration of Van Reede with Matthews came as an unpleasant surprise. ${ }^{68}$ Matthew's position as Catholic priest was met with criticism in the Protestant Republic. Van Goens criticised Van Reede's collaboration with Matthew by saying that, 'he (Matthew) now evidently had supreme power over all the Christians in Cochin'. ${ }^{69}$ Nevertheless, Van Reede ignored the criticism and include his name in the Hortus Malabaricus.

Matthew was assisted by Johannes Casearius, a clergyman in Cochin, in making the Latin version of the manuscript. The medium of communication between the Dutchmen and locals was Portuguese. As discussed in the last chapter, the presence of Luso-Indian communities on the Malabar coast made Portuguese the intermediary language between the Indians and the Dutch at the time. But the plant descriptions in the work were compiled in Latin, as Latin was popular as

\footnotetext{
${ }^{64}$ For a full descriptive analysis of the history of Matthew's activities and work, see Ibid: 39-41.

65 See, Desmond, Great Natural History Books, p.39. Some scholars argue that the copy found in the British Library refers to Matthew as the author. See Sita Reddy, 'Hortus Indicus Malabaricus' in Marg: The Weight of a Petal: Ars Botanica, Vol. 70, no. 2, Dec 2018, p. 62. British Library's catalogue record and accession notes (from 1771) mention Matthew as the artist: 'Drawings in Indian ink', of the plates in work 'Hortus Indicus Malabaricus by Matthaeus Joseph'.

${ }^{66}$ Zupanov and Xavier, 'Quest for Permanence', p.534.

${ }^{67}$ The Padroado was an arrangement between the Holy See and the Kingdom of Portugal and later the Republic of Portugal, through a series of concordats by which the Vatican delegated the administration of the local churches and granted some theocratic privileges to Portuguese monarchs.

68 Ines G. Zupanov, "Amateur Naturalist and "Professional" Orientalist; Paulinus S. Bartholomaeo in Kerala and Rome (18th-19th c.)', Review of Culture, no. 20, 2006, pp.77-101. A similar account of Fr. Mathews is also given in congregation website. (http://verapolyheritage.org/legacies/ accessed 12 May 2019).

${ }^{69}$ Heninger, Hendrik Adriaan van Reede, p.44.
} 
the language of learning. In translations, Matthew and Casearius were assisted by Christiaan Herman van Donep, who was a secretary in Cochin. Plant names were written in Malayalam (the language of Malabar), Sanskrit (the language spoken by upper caste Brahmins), Latin and ArabiMalayalam. ${ }^{70}$ The seventh and eighth volumes of the print have plant names in Flemish as well. ${ }^{71}$

This polyglot, collaborative endeavour, however, opened up Van Reede to criticism by his detractors, including even Van Reede's second-in-command, Gelmer Vosburg. In his report of 1675 about the administration of Van Reede, Vosburg wrote about Matthew:

This Italian or Neapolitan has managed to warm himself so much into the good graces of the commander Van Reede that he is almost considered a saint; he is considered to be an expert doctor of medicine and a good herbalist; that is why he has all the more opportunity to ransack every hole, to call on the sick and visit the houses.....now in Cochin they are engaged in making with this Carmelite a herbarium of all sorts of herbs, roots, plants, etc. ${ }^{72}$

As mentioned in the quote, there must have been a herbarium in the making in Cochin. The contemporary Kerala botanist and translator of the twelve volumes of the Hortus Malabaricus to English and Malayalam, K.S. Manilal argues that Van Reede sent some living plants from Ceylon and Malabar to the botanical garden in Amsterdam. ${ }^{73}$ But the catalogues of the Amsterdam Botanical Gardens have no references to plants arriving from Malabar. Although this is highly likely, the lack of authentic dried specimens has hindered the identification of many plants. ${ }^{74}$

Van Reede submitted initial drafts of his book to an advisory board which consisted of staff from the Dutch hospital. Unlike in Batavia and Ceylon, the Company did not have an official physician in Malabar. Apart from the Dutch staff working in the hospital, the information regarding the medicinal properties of plants came from local physicians, herbalists and collectors of plants. Size of settlement. It is significant here to examine how a small settlement such as Malabar provided the diversity of expertise to produce a work of this magnitude. Van Reede's position as Commander brought people from various professions, such as translators, physicians, administrators, draughtsmen, to work for him. The compilation of the Hortus Malabaricus entailed various processes of management across these fields: compiling, diplomacy, the choice of clientele

\footnotetext{
70 The use of Arabi-Malayalam could be because Malabar had long trading connections with the Arab world, so Malayalam had influence from Arabic. The potential of extending trade in medicines to Persia could be another reason. Also argued by Heninger and Govindankutty, see J. Heninger, Hendrik Adriaan van Reede, p. 149.

${ }^{71}$ See, Title pages of $V$ an Rheede's Hortus Malabaricus, Vols 7 and 8.

72 Heninger, Hendrik Adriaan Van Reede, p. 43-44.

${ }^{73}$ K. S. Manilal, Botany and the History of Hortus Malabaricus (Rotterdam: A. A. Balkema, 1980), p. 2.

${ }^{74}$ Manilal, Botany and the History, p. 2.
} 
and personnel. ${ }^{75}$ But the Hortus Malabaricus and its early medico-botanical research did not receive the attention Van Reede had hoped to receive from the High Government in Batavia. The next chapter will discuss how there was some level of interest in botanical research among the Company Directors such as the botanical interest of Joan Huydecoper. Nevertheless, there was no adequate interest that would sustain the official bioprospecting in Malabar. It is worthwhile to note here that the hierarchical structure of the VOC was such that the High Government at Batavia made major decisions in the affairs in Asia. To seek funding for botanical activities in Malabar, Van Reede required support from the Batavian administration which he did not receive.

The constant criticism of his research activities in Malabar prompted Van Reede to leave Malabar. In his letter of 28 October 1677 to Lords XVII, Van Reede sent his resignation as commander of Malabar. In his detailed Memorandum to his successor Jacob Lobs (written in 1677), Van Reede does not mention the Hortus Malabaricus or his botanical activities. In the face of lack of patronage and criticism, he restricted his writings to the description of the land, various ruling kingdoms, castes and recommendations on policies in the tropical region. ${ }^{76}$ Thus, I have not found any copy of Van Reede's Hortus Malabaricus in the VOC archives. What is of significant interest to this study is the diversity of local knowledge sourced for the Hortus Malabaricus.

\section{Indigenous Knowledge in the Hortus Malabaricus}

Since the time of the Portuguese in Goa, knowledge was gathered by Europeans from local practitioners such as hakims and vaidyas, and then reported as 'Indian' treatments for tropical diseases unfamiliar to European physicians. For the collection of plants, including their identification, description and sketching and painting (in ink-and-wash) of specimens, Van Reede gathered a team of local experts including Ayurvedic physicians, Konkani Brahmins at the court of Cochin ruler, and translators. The local experts who collaborated with Van Reede are largely classified as 'informants'. The risk of such terminologies is that they represent the local agency in knowledge-making as passive, and also as a homogenous group. The locals who assisted European officials are usually represented as merely responding to questions framed by Europeans

\footnotetext{
75 Susan Leigh Star and James R. Griesemer, 'Institutional Ecology, 'Translations' and Boundary Objects: Amateurs and Professionals in Berkeley's Museum of Vertebrate Zoology, 1907-39', Social Studies of Science, Vol. 19, no. 3, Aug. 1989, pp.389-90.

${ }^{76}$ For a full-length analysis of Van Reede's Memorandum, see s'Jacob's, Nederlanders in Kerala, 1663-1701. Memories and instructions concerning the Malabar command of the Dutch East India Company (s' Gravenhage, Nijhoff, 1976).
} 
investigators. ${ }^{77}$ Historians have described these informants as passive, peripheral, or powerless in their role of knowledge-making. In the case of Malabar, while the court of the ruler of Cochin played the venue for meetings, Reede's project benefitted from the medico-botanical knowledge of local physicians, herbalists and collectors. Though they played a crucial role in the construction of knowledge, their contributions were cornered into the one-page prefaces of the volumes. For example, in the Preface to Vol. 1, translator Johannes Casearius, wrote,

As regards the diagrams, in them are depicted plants with their chief parts like flowers, fruits, seeds in their natural size and portrayed life like... as regards medical uses we have chosen them both from the discoveries of Rev. Fr. Matthew, a Carmelite, and from the mouth of expert doctors like Ranga Bhatt, Vinaya Pandit and Appu Bhatt, Brahmins and Itty Achuden, a man from the Chego race as is evident from their testimonies; to which are added the properties by us; and in this manner have I prepared the first part of this Malabar Garden. ${ }^{78}$

We know the names of the three physicians who assisted Van Reede in describing the medicinal properties of plants: Ranga Bhatt, Vinayak Bhatt and Apu Bhatt, the three Brahmin physicians (vaidyan in Malayalam) from Cochin and physician and herbalist Itty Achuden. The diversity inherent in the Hortus Malabaricus comes from the diverse epistemes practised by the Carmelite priest, Brahmin physicians and Ezhava herbalist, all of whom engaged in the identification of plants and their medicinal properties. Their contributions cannot be fully understood as the text fails to specify the plants or the medicinal properties contributed by each physician. Moreover, since their knowledge was reworked in Europe, the information was codified in a descriptive botanical arrangement without any local context. Environmental historian Richard Grove argued that the Hortus Malabaricus recognized the knowledge systems present in the Malabar Coast, such as the medical tradition of the Ezhavas. ${ }^{79}$ Grove based his arguments on the testimonies of Malabari physicians in Volume 1 and Van Reede's acknowledgement of their contributions in Volume 3. In conclusion, Grove calls the Hortus Malabaricus an 'indigenous text'. ${ }^{80}$ In his view, the increasing professionalization of natural history seems to have facilitated the diffusion and dominance of Ayurvedic and Ezhava epistemologies alongside the erosion of older European and

\footnotetext{
${ }^{77}$ Kapil Raj, 'Thinking Without the Scientific Revolution: Global Interactions and the Construction of Knowledge', Journal of Early Modern History Vol. 21, 2017, pp.455.

78 Van Rheede's Hortus Malabaricus, Vol. 7, pp: xxxviii-xxxiv.

${ }^{79}$ Grove's work still centers on Van Reede's role in understanding Malabar flora and exposing it to Europe. It also ties easily with Grove's larger argument of European sympathizers in search of tropical Eden.

${ }^{80}$ Grove, Green Imperialism, p.83.
} 
Arabic systems. ${ }^{81}$ Later historians followed Grove's argument without further interpolation of native knowledge-systems, which were diverse in nature. According to Dr. Ajayan, the plants in the Hortus Malabaricus were studied according to its Dravya (drug and diet), Guna (property), Rasa (taste), Veerya (potency) and Karma (action) which formed the basis of Ayurveda pharmacology. ${ }^{82}$ The practice of obtaining botanical specimens and collecting samples of drugs and studying their seasonality as well as genuses and sub-genuses, which is characteristic of the Hortus Malabaricus, is a European practice which can be traced back to da Orta. ${ }^{83}$

The Hortus Malabaricus contained both European and local elements. It followed a classificatory system that was known in Europe at the time. It classified the plant species into trees, shrubs, fruit-bearing plants and so on. ${ }^{84}$ Within the description of the plant, the order of the description was as follows: root, stem, leaves, flowers and fruits. For example, one can refer to the descriptions of plant Cara Nosi in Volume Two. ${ }^{85}$ However, the work also contained local and cultural knowledge. It has interesting discussions on how drugs were used by the indigenous communities. For example, in the section on Codda Pana or the palm tree seen in Malabar, there are detailed descriptions of how the plant, despite not having major medicinal values, is used by local communities in different ways. It describes how the juice from the tender bark is hardened by exposing it to the sun and later given to pregnant women for aborting the foetus. The description further states that the 'Malabaris use the leaves for the roofs of their houses and even for writing in them' ${ }^{86}$ The Hortus Malabaricus can thus be considered a significant work not just on medicines, but as one that describes medicinal, non-medicinal and commercial uses of plants. The knowledge of local pharmacopeia was dispensed by practising physicians and healers belonging to different communities.

Interestingly, the same section on the palm tree has a picture depicting a few men carrying its branches; one of them is identified as suffering from Elephantiasis. ${ }^{87}$ Dutch historian Heninger notes that the VOC physician in Batavia Andries Cleyer identified the disease being common among St. Thomas Christians in Malabar. ${ }^{88}$ Singh's work on the life of VOC officials in Fort Cochin also makes a reference to this disease. She writes that a 'common disease, although not

\footnotetext{
${ }^{81}$ Grove, 'Indigenous Knowledge and the Significance', p.127.

82 S. Ajayan, 'An Outlook of Kerala Health Traditions in Hortus Malabaricus', Quarterly Medical Journal, April-June 2016, pp. 18-19.

${ }^{83}$ Binny, 'Plants, Power and Knowledge', p. 16.

${ }^{84}$ Van Rheede, Hortus Malabaricus, see the classificatory system used.

85 Van Rheede, Hortus Malabaricus, Vol. 2, pp. 21-23.

86 Van Reede, Hortus Malabaricus, Vol. 3, pp. 13-14.

${ }^{87}$ Elephantiasis is tropical, parasitic disease that affects the lymph nodes and vessels. Better known as lymphatic filariasis, it is spread by infected mosquitoes. See image in Van Rheede, Hortus Malabaricus, Vol. 2, Fig 3, p. 3.

${ }^{88} \mathrm{~J}$. Heninger, Hendrik. Adriaan van Reede tot Drakenstein (1636-1691) and Hortus Malabaricus: A contribution to the bistory of Dutch colonial botany (Rotterdam and Boston: A. A. Balkema, 1986), p 144.
} 
fatal, was elephantiasis. It was so widespread in Malabar that the disease in former days was called Cochin-leg. It left the patient with swollen legs which resembled that of an elephant. ${ }^{89}$ This would mean that whoever made the drawing of the men carrying the tree branches made it on the basis of observation of real-life situations. They were the Company draughtsmen who thought that this particular trait was worth recording rather than drawing all native men as looking alike.

By the late eighteenth century, the Hortus Malabaricus was mainly popular as a reference guide for tropical plants and medicines. But as these examples illustrate, it was a multifaceted work that contained information about local plants, customs, and different types of illnesses. Unlike other treatises written before the Hortus Malabaricus, Van Reede not only prepared a medicobotanical manual for effective pharmacopeia but a comprehensive work on Malabar nature.

I argue in this thesis that the text was never fully indigenous or European; it was hybrid in nature. The reason for the argument is the diverse epistemes which were 'lost in translation' in the final print, overwritten by the framework and conventions of European natural history at that time. Attempts to analyse the relationship between Western and indigenous knowledge systems have failed to address the heterogeneity in the medical practices of caste-based groups of physicians and healers. Furthering Grove's argument of epistemologies, this thesis explores the diversity in the knowledge systems of Brahmin physicians and Ezhava physician who collaborated in the making of the Hortus Malabaricus. Both Brahmins and Ezhavas practised vaidyam but the Ezhava vaidyam of Itti Achuden should be treated as different from the Brahmin vaidyam of Ranga Bhatt, Apu Bhatt and Vinayak Bhatt which was probably scripture based. Itti Achuden's statement in Volume I of the Hortus Malabaricus that 'I told, dictated names, medical powers and properties of plants, trees....I had observed by long experience and practice' indicates that local methods of cure were based on observation and interpretation. ${ }^{90}$ The regional texts like Chikitsa Manjari, Yogamrutham, Sabasrayogam refer to plants mentioned in the Hortus Malabaricus and were treated as parts of Ezhava-vaidyam (non-Brahminic medicinal tradition practised by Ezhava caste) in which treatment is based on medicine, diet and exercise. ${ }^{91}$ Any indigenous medicine that had the ability to cure was also ritually believed to expel bad omens and act against cures. ${ }^{92}$ Such local ritualistic specificities were lost when the work reached the Republic. The significance of Malabar plants was reduced as specimens for study. By exploring the sites of indigenous knowledge in the same way

\footnotetext{
${ }^{89}$ Singh, Fort Cochin Kerala, p. 142.

${ }^{90} \mathrm{~V}$ an Reede's Hortus Malabaricus, Vol. 1, Foreword, non-paginated.

${ }^{91}$ In the nineteenth century, as an antithesis to colonial medicine, Ayurveda and Unani rose to prominence in India, but they did not fall under any systematic group but was a collection of medicinal practices followed by the native physicians. Burton Cleetus, 'Subaltern Medicine and Social Mobility: The experience of the Ezhava in Kerala', Indian Anthropologist, Vol. 37, no. 1, 2007, p.155.

92 Cleetus, 'Subaltern Medicine and Social Mobility', p.151.
} 
that we explore the sites of Western scientific knowledge, we can attain a better position for effective comparison of these quite disparate knowledge systems. ${ }^{93}$

In the British colonial period, many medicinal practices were revived under the umbrella category of Ayurveda which resulted in a burying of the diversity of medicinal knowledge traditions in South Asia. The different local knowledge-systems were institutionalized in the nineteenth century as an antithesis to Western medicine. While in India, the revival was part of the anticolonial struggle, Alix Cooper argues that European writers created the idea of the 'indigenous' to defend themselves against the foreign and strange influences that had entered European culture following the Columbian encounter. ${ }^{94}$ Apart from the fact that indigenous bodies of knowledge may often be sophisticated in content, as has been increasingly recognized in areas like taxonomy, indigenous knowledge centres employed complex assemblages of information, which might include maps, calendars, training of personnel, techniques, procedures, skills, and the preparation of texts. ${ }^{95}$ The ownership of medicinal plants, though extremely complex, and their traditional knowledge, were the most valuable assets of indigenous people. In other words, indigenous involvement in the production of natural knowledge is neither trivial nor inconsequential and was, moreover, highly diverse, rather than simply being 'indigenous'. The initial drafts of the Hortus Malabaricus compiled by Malabar physicians followed a combination of native medicinal traditions, but the print form had rearranged information based on European taxonomy. The Hortus Malabaricus signifies the heterogeneity in the knowledge-making of early modern medico-botanical treatises. By merely defining it as indigenous, the pluralist traditions in the Malabar medicinal practices were appropriated to produce an apparently homogenous 'new knowledge' in natural history. To know more about the making of this 'new' knowledge, the chapter will now examine Van Reede's attempts to publish the work in Europe.

\section{Fashioning Flora in the Republic (1686-1703)}

After having met with criticism for his scientific endeavours in Malabar, Van Reede, along with Casearius, the Latin translator, left for Batavia in 1677. After a short stint there as the Extraordinary Councillor of India, Van Reede resigned in October 1677 and returned to the Netherlands. While in Batavia, Van Reede might have been in contact with others with similar interests, such as

\footnotetext{
${ }^{93}$ David Wade Chambers and Richard Gillespie, 'Locality in the History of Science: Colonial Science, Technoscience, and Indigenous Knowledge', Osiris, Vol. 15, 2001, p.231.

${ }_{94}$ Alix Cooper, Inventing the Indigenous: Local Knowledge and Natural History in Early Modern Europe (Cambridge: Cambridge University Press, 2007), p.176.

${ }_{95}$ Chambers and Gillespie, 'Locality in the History of Science', p. 230.
} 
Andries Cleyer (company surgeon), Herman Grimm (physician), ${ }^{96}$ and Willem ten Rhijne (physician and botanist).

In the preface to Volume 3 of the Hortus Malabaricus, Van Reede writes about continuing his work which he had been forced to interrupt due to his departure from Malabar. ${ }^{97} \mathrm{He}$ also found in Batavia few plants whose illustrations were incomplete. With the aid of painters in Batavia (whose names are not mentioned), Van Reede completed some of the illustrations for the volumes of the Hortus Malabaricus. Heninger argues that he relied on Hendrik Claudius, who was then present in Batavia and was famous for watercolour paintings of Cape plants and animals done in 1682 by order of surgeon Cleyer. ${ }^{98}$ It should be noted however that the Hortus Malabaricus did not have any watercolour paintings. The illustrations in the Hortus Malabaricus are double folio drawings made with a different technique of copperplate engravings. ${ }^{99}$ However, although we are not sure about their identity, the fact remains that in Batavia, Van Reede had assembled a group of artists who could draw life-like images of the Malabar plants. While in Batavia, he might have also received assistance from physicians and artists stationed at the castle.



Fig. 6. Illi from the Hortus Malabaricus, Vol. 1 (Courtesy: Edward Worth Library)

\footnotetext{
${ }^{96}$ Herman Grimm was a Danish physician employed by the Company for some years in Ceylon along with Paul Hermann. In Batavia, Grimm supervised the surgeons, while he also prepared medicaments in a laboratory (1679). Grimm also published in 1677 the Laboratorium Chymicum, gehouden op het voortreffelijke Eylandt Ceylon, a survey of all the medicines and their preparation, of animal, vegetable, and mineral origin, found in Ceylon. It is probably the first work of natural science that came from the Company's printing press in Batavia. In the same year, Grimm also requested under the instructions of Van Goens consent for setting up a laboratory in Ceylon for the whole of India. Willem ten Rhijne was a Dutch physician and famous as the physician sent on the request of Japanese Shogun to Deshima.

${ }^{97}$ Van Rheede's Hortus Malabaricus, Vol. 3, P. xxi.

${ }_{98}$ Heninger, Hendrik, Adriaan Van Reede, p.52.

${ }^{99}$ Heninger should be read with caution as he makes sweeping assumptions about people involved with Van Reede.
} 


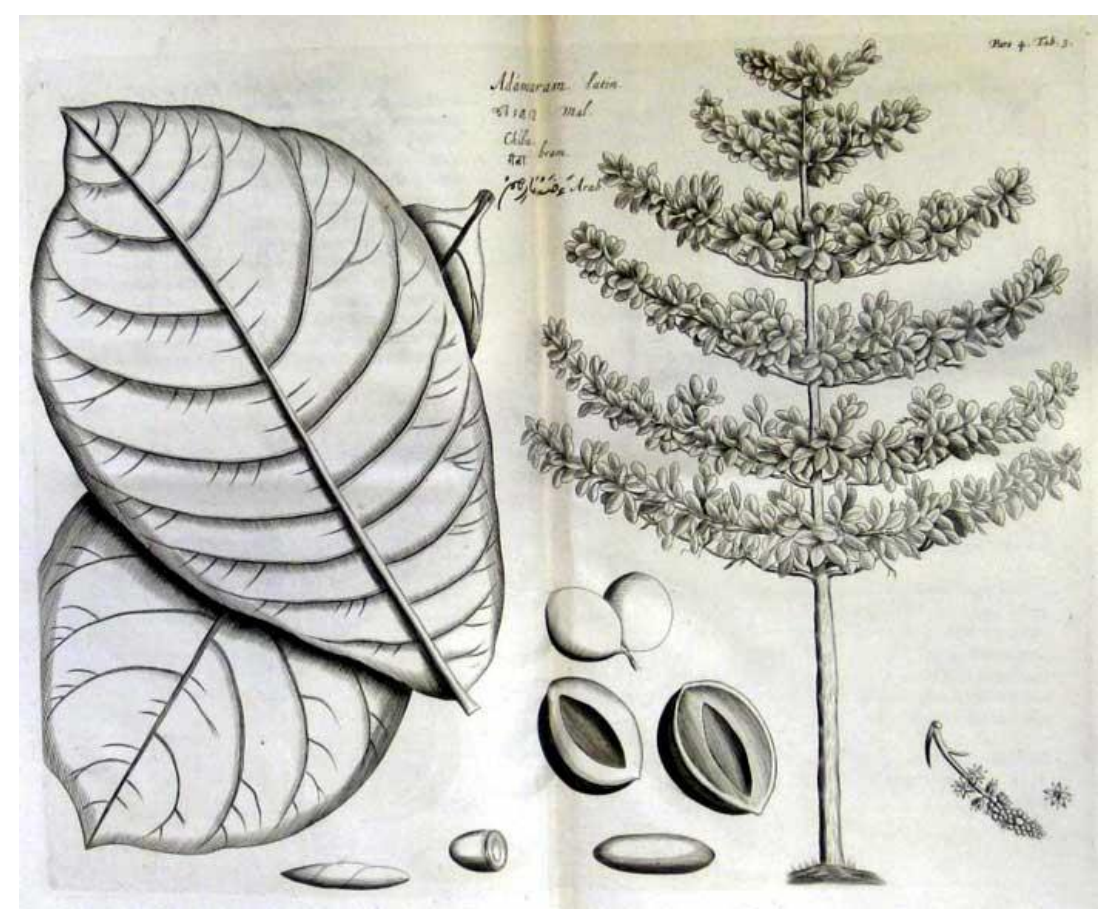

Fig. 7. Adamaram from the Hortus Malabaricus, Vol 4 (Courtesy: Edward Worth Library)

All twelve volumes of the work are in folio format and contain a total of 791 copper engravings of plants, mostly of double-folio size (see figs. 6 and 7$)^{100}$. Some plants are described in detail, with more than one engraving; thus, the work contains 725 different species engraved in 791 copper plates. The large size of the engraving $(34 \mathrm{x} 43 \mathrm{~cm})$ required a different arrangement (see, fig. 6). ${ }^{101}$ The size is based on the size of the original drawings made in Malabar and was probably determined by Van Reede or his draughtsmen to show plants in life-size. ${ }^{102}$ Only two of the 651 drawings in the British Library bear artist signatures. ${ }^{103}$ A double-folio drawing (fig. 8) of Malabar's coconut tree, signed by Antoni Goetkint, became the template for one of the Hortus Malabaricus's most celebrated engravings in print. ${ }^{104}$ Goetkint's signature can be seen in the lower left corner of the drawing as well as in the engraving (on the right), which also includes the name of the engraver, Bastiaan Stoopendael. Just as the artists were invisible and anonymous, so too

\footnotetext{
100 'Botany at the Edward Worth Library: Hortus Indicus Malabaricus', https://botany.edwardworthlibrary.ie/floras/asia/hortus-indicus-malabaricus/accessed 05/06/19. 101 Ibid.

102 Manilal, Botany and the History, p.11. The original drawings (Icones) are now at the British Library. The monochrome ink-wash drawings in the British Library collectively known as 'Horti Malabarici Icones' correspond exactly with engravings made for the first ten published volumes of the Hortus Malabaricus. See, Reddy, 'Hortus Indicus Malabaricus', p.60. 103 Ibid, p.58.

104 Antoni Jakobsz Goetkint belonged to a family of Antwerp artists by that name and Marcelis Splinter, who signed fig. 39 in Vol 6 Latin version stemmed from a family of painters and sculptors who worked on the cathedral of the city of Utrecht.
} 
were the engravers; only two plates were signed in the Latin edition of the Hortus Malabaricus, first by Bastiaan Stoopendael and the second by Gonsalez Appelman.

The early modern scientific and natural history works seldom gave credit to the many collaborators who were involved in its making. Often, smaller artist communities were not named or acknowledged in print. The production of botanical work meant a balancing act of rendering an image that was neither too schematic nor too detailed which might make it unclear. ${ }^{105}$ Botanical illustrations were a working tool to make sense of the natural world and were completed by commissioned professional draughtsmen. Similarly, the illustrations in the Hortus Malabaricus were intended to supplement text with visual information. For example, Casearius writes in Volume 1:

With regards to diagrams, plants are depicted with their chief parts like flowers, fruits, seeds, in their natural size and portrayed life like and so I shall not doubt that our description may not be perfect in all aspects, but when compared with diagrams would be sufficient to acquire a clear and distinct knowledge about these plants. $^{106}$



Fig. 8. Tenga (coconut tree), Hortus Indicus Malabaricus Vol. 1, fig. 2 (Courtesy: Wellcome Collection) ${ }^{107}$

The print technology and double folio paintings used in the volumes of the Hortus Malabaricus reflect the artistic conventions of the Dutch golden age. The pen-and-ink drawings of plants gathered from Malabar were reconfigured to suit the print technology of the copperplate engraving in the Dutch metropoles. ${ }^{108}$ Illustrations and notes on the manuscript preserved the

\footnotetext{
${ }^{105}$ Fleisher, 'Breyne’s Botany: (Re-)locating Nature', p.133.

106 Van Rheede's Hortus Malabaricus, Vol. 1, p. x.

${ }^{107}$ 'Tenga', Hortus Indicus Malabaricus, Wellcome Collection, https://wellcomecollection.org/works/f9s33ejx accessed $10 / 06 / 19$

108 The techniques of 'pattern welding' and 'copper plating iron' are the direct forerunners of etching and modern printmaking. Etching copper printing plates was first performed with nitric acid, both in Italy and the Netherlands; alternative recipes for salts-in-vinegar mordants appear in Italy in the 1560s. In 1520, Lucas van Leyden produced six
} 
experience of the author from the field or that of an artist. Art historian Sita Reddy draws attention to this artistic process by which Dutch military artists were in possible dialogue with local scholars. In the case of the Hortus Malabaricus, the artists' depictions reflected Baroque styles of book illustration and late $17^{\text {th }}$-century Flemish painting styles dominated by still life and perspectival realism. ${ }^{109}$ The Company science relied on art for its visual representations of tropical botany. ${ }^{110}$ From the making, printing and visual translation from field-to-page to copper-plate, the process represents a remarkable tale of colonial encounter and knowledge-exchange.

As models for the engravings, each of the 650 Icon drawings (590 in double-folio and 61 in folio) was carefully copied onto copperplates (chalk-blackened backs and burin outlines are visible in verso). ${ }^{111}$ The process of graphic conversion from drawings to engravings, as well as visual ruptures and omissions are all present in the correspondences. Some leaves, flowers, fruits and seeds and a hundred fanciful insets featuring dragons, mermen, animals and allegorical figures from the European Baroque are omitted in the print form. The draughtsmen occasionally added human figures to the drawings, but these too were omitted in print. ${ }^{112}$ The omission of the human figures should be seen as taking away the human agency of local people from the text to transform it to a work of Dutch genius. Also, the removal of human figures delocalizes native plants. This practice can be seen in the light of standardisation of taxonomy in the seventeenth century. An analysis of the initial ink drawings shows how the accompanying description and the organization of plants into taxonomical classification occurred in Europe with the engagement of European trained or amateur scholars.

Before leaving Batavia for the Netherlands, Van Reede sent home some drawings of Malabar trees, shrubs and herbs. Interestingly, for fear of a shipwreck or other hazards of the sea voyage, he also left a copy of the drawings with Ten Rhijne in Batavia. ${ }^{113}$ Thus, few copies of the initial drawings were already in circulation before the first print appeared in Amsterdam in 1678.

etchings with additional engraving on copper printing plates in Leiden. References to etching copper printing plates with nitric acid are found in Italy in the sixteenth century and in northern manuals from the early seventeenth century onwards. For a detailed analysis of copperplate printing technique, see, Adrianus Cornelis Jacobus Stijnman, 'A History of Engraving and Etching Techniques: Developments of Manual Intaglio Printmaking Processes, 1400-2000’ Unpublished PhD Thesis, University of Amsterdam, 2012.

109 Reddy, 'Hortus Indicus Malabaricus', p.58.

110 Ibid.

111 Ibid. The process of making copperplate engravings are briefly described by Heninger, Hendrik Adriaan Van Reede, p.130. Usually, the engraver covers the back of the drawing with black or red chalk. Then the paper is pasted on a copperplate and pressed through the outlines of the figure with a burin (a metal tool used in engraving in wood or metal) to produce the rough sketch of the plant in black or red on the plate.

112 Ibid, pp.59-60.

113 There is no evidence of any copy that Ten Rhijne possessed. After his death in 1700, his scientific writings seem to have disappeared. (The same action was also taken by Georg Eberhard Rumphuius (another Dutch botanist) when he made drawings for his Herbarium Ambionese. Unlike Van Reede's safe journey, the first copy of Rumphius's work sank in 1692, which led him to depend on the text that he had left behind. 
The publication dates of the Hortus Malabaricus are also disputed, as the volumes seem to have circulated at different times in Europe. In the bibliographical notes in an article on the Hortus Malabaricus, one anonymous author identifies a problematic pattern for identifying the exact dates of the publication of its different volumes. He writes, "with such evidence of diversity, as have been presented, it seems not unlikely that copies or notices of publication may be in existence which would support these intimations of earlier dates." 114 He argues that some of the volumes of the Hortus Malabaricus have been misquoted, and misdated. For instance, 'Part IV is accepted to have been published in 1673, but Pritzel's Thesaurus gives the date as 1683. In another instance, the first volume of the Hortus Malabaricus published in 1678, many copies do not have the original title but the one dated 1686. Hence, years 1686-1703 is taken as a bracketed date for the entire work. ${ }^{115}$ It is highly likely that the earlier volumes of the Hortus Malabaricus travelled across Europe upon publication before the later printed editions with title pages were published.

From the printing of the first volume in 1678 to the twelfth volume in 1693, the production of the Hortus Malabaricus suffered significant setbacks. Firstly, Johannes Casearius, who had made the Latin translations of the descriptions of plants, died in Batavia before he could reach the Netherlands. The double-folio engravings involved considerable expenses, and the publishers were hesitant to invest in this expensive publishing venture. ${ }^{116}$ The first and the second volumes of the work were published by Amsterdam publishers, Jan van Sommeren and Jan van Dyck. ${ }^{117}$ Arnold Syen, professor of botany at Leiden University, wrote commentaries for these volumes and presented a copy to the university in 1678. As commentator, Syen followed Swiss botanist Casper Bauhin's taxonomical classification based on his work Pinax theatre botanici (1623) that divided flora into traditional groups such as trees, shrubs and herbs. ${ }^{118}$ When it appeared in print, it was found that the publishers had reworked the contents of the first and second volumes. While Van Reede planned to publish the first volume on trees and the second on shrubs, the printed version had some descriptions of the shrubs and trees in both the first and second volumes. Publishers were not aware of the monumental work that Van Reede had envisioned and thought the work would be published in three volumes. Instead, the Hortus Malabaricus was finally published in twelve volumes. ${ }^{119}$

\footnotetext{
${ }^{114}$ The author is cited in Marjorie F. Warner, 'The Dates of Rheede's Hortus Malabaricus', The Journal of Botany, Vol. 58, December 1920 (not paginated).

115 Ibid.

116 In 1721, the commercial value of the copper plates and the stocks of the Hortus Malabaricus amounted to 2,963 guilders.

117 The recent English translation credits widow of Jan van Sommeren, heir of Jan van Dyck Henry and widow of Theodore Boom for funding the publishing of all volumes. Heninger argues that it was only from the third volume, the people mentioned above were involved.

118 Heninger, Hendrik Adriaan Van Reede, p. 83.

119 Ibid, p. 102.
} 
The production of the Hortus Malabaricus was affected again by the deaths of some of Van Reede's collaborators. The commentator of the first volume, Arnold Syen, died in 1678, followed soon after by those of the publishers Jan van Dyck and colleague Jan van Someren. Later volumes were funded by the widows of these publishers. Syen's work was later taken up by Jan Commelin, a reputable amateur botanist who held a high status within the Amsterdam burgher society. In November 1682, the Amsterdam city council founded the Amsterdam Municipal Garden and entrusted the administration to Johan Huydecoper and Commelin. During their tenure, exotic plants were brought to Amsterdam, which led to the rapid rise of the reputation of the garden, much like the Leiden botanical garden (discussed in the next chapter). ${ }^{120}$

Johannes Munnicks, professor of botany and anatomy and Director of the botanical garden of Utrecht University, provided descriptions and translations in Volume 5 of the Hortus Malabaricus. ${ }^{121}$ Munnicks was widely known for publications in the field of surgery and did not have any botanical works to his credit. Nor did the Utrecht botanical garden have any exotic plants in that period as there were no greenhouses. ${ }^{122}$ After a short stint, after the fifth volume of the Hortus Malabaricus, Munnicks passed on the job as a translator to Theodorus Janssonius van Almeloveen, who then worked on the sixth volume. The Amsterdam physician Abraham van Poot completed the translation and compiling of the remaining six of the twelve volumes. ${ }^{123}$ Poot had little understanding of botany, let alone tropical plants. Writing in Volume 8 (1688), Poot notes:

While I gathered the eighth part of Hortus Malabaricus incomprehensible where the author was dealing with the description "fruiticus". But when I came to Tabula XXII and carefully went through the rest, I found that I made an error, that portion did not deal with fruits but herbs. Therefore, instead of Fruitex or Fruitex qui read 71erb aquae. ${ }^{124}$

Thus, from enterprising to collecting, coding, classifying and naming plants, knowledgeproduction went through many hands and intellectual systems. Those involved in its production belonged to various professions of the newly emerged Republic, but were loosely connected to botany, medicine and commerce. The link between author and text was further obscured by the many editorial hands that it went through before it was finally published in the late seventeenth century. Van Reede's control over the published material, its structure and plant naming was lost

\footnotetext{
${ }^{120}$ Dirk Onno Wijnards, The Botany of the Commelins (Rotterdam: A. A. Balkema, 1983), p. 3.

${ }^{121}$ Van Rheede's Hortus Malabaricus, Vol. 5, p. ii.

122 A.J. van der Aa, Biographisch woordenboek der Nederlanden. Deel 10 (Haarlem: J. J. Van Beedeeode, 1862), pp. 656657.

${ }^{123}$ Heninger, Hendrik Adriaan Van Reede, p. 63.

124 Van Rheede's Hortus Malabaricus, Vol. 8, p. ix.
} 
in the process. In other words, 'the metropolitan expert using his social and physical position overruled the distant colonial' in what was written. ${ }^{125}$ Van Reede did not see the publication of the twelfth and the final volume in 1693, as he had left for Asia in 1684 as the new CommissionerGeneral of the Western Quarters (Asia). Though Van Reede visited Malabar in 1691, there are no further reports on any botanical research initiated by him. After inspecting Dutch settlements, he died on 15 December 1691, off Bombay and was buried at Surat (in modern Gujarat). ${ }^{126}$

So, what did the publication of Hortus Malabaricus do for Van Reede? The work did not bring immediate success in terms of any official decisions to further pursue botanical research in Malabar or any botanical expedition in the region. To secure a better position in the Republic, Van Reede would later adopt the title, 'Lord of Mydrecht' for himself in the year 1683. Secondly, Van Reede's desire to produce 'the' work on Malabar botany that would elevate the settlement of Malabar over that of Ceylon also did not materialise. This could also be seen as what historian Jim Endersby calls 'botanical nationalism' that a naturalist would feel for his adopted land not to be seen as florally impoverished. ${ }^{127}$ As Chapters 4 and 5 of this thesis will argue, the Company administration became less interested in Malabar in the eighteenth century. Moreover, Van Reede was sent to the Dutch settlement in Cape in 1685 only to return to Malabar in 1691. The delay in a multi-year project caused by copperplate engravings, funding, suitable editors and commentators resulted in the publication of a piecemeal work that slowed down the immediate scholarly response which Van Reede had hoped for.

The internal politics between settlements In Ceylon and Malabar affected the networks of botanical research of the Indies. Religious opposition to the Catholic contribution mostly affected the profitable economic botany that otherwise existed in the Republic. The history of production of the Hortus Malabaricus indicates the volatile networks of commerce, botanical science and state politics that existed in the early modern period. To borrow Deborah Harkness' arguments on the development of Elizabethan science, 'the scholarly emphasis has always been on the print culture rather than manuscript culture and historiography has focused on singular great men rather than collaborative communities', which has left little information regarding the networks of artists and engravers who worked with Van Reede. ${ }^{128}$ Similarly, the historiography on the Hortus Malabaricus has focussed on Van Reede, and this has led to shallow understanding of the multiple knowledge-

\footnotetext{
125 Jim Endersby, “"From Having no Herbarium.” Local Knowledge versus Metropolitan Expertise: Joseph Hooker's Australasian Correspondence with William Colenso and Ronald Gunn', Pacific Science, Vol. 55, no. 4, 2001, p. 343.

${ }^{126}$ Heninger, Hendrik Adriaan Van Reede, p. 21.

${ }^{127} \mathrm{Ibid}, \mathrm{p} .350$.

${ }^{128}$ Deborah E Harkness (ed.), 'From the Jewel House to Salomon's House: Hugh Plat, Francis Bacon, and the Social Foundations of the Scientific Revolution', Elizabethan London and the Scientific Revolution (Yale: Yale University Press, 2007), p.252.
} 
systems that have interplayed in producing this early modern natural history work through various people who were involved in the knowledge-making process.

Nevertheless, Van Reede was successful in creating knowledge-networks through his multivolume project. Two kinds of networks evolved in the early European bioprospecting: firstly, the botanists and naturalists working in the tropics stabilized natural knowledge through direct observation and first-hand experiences of collecting East Indies flora; secondly, the correspondence networks generated a familial bond whereby people depended on each other for information, specimens, references, consultation and collaboration. At times, they worked on multiple projects and had multiple careers. As seen, most of them were statesmen, merchants, physicians and amateur botanists at the same time. At times, they belonged to more than one network: for instance, Jan Commelin and Jan Huydecoper had connections within the Republic with their position as Directors of Amsterdam Botanical Garden and engaged in commercial networks to import rare and tropical plants from the overseas Dutch settlements. What resulted was a collaboration among numerous people stretched across the Republic, and that incorporated overseas and metropolitan territory, who engaged in a common project like the Hortus Malabaricus, thereby providing points of contact for widely separated figures, creating sets of exchanges in different directions. Figures like Jan Commelin, Johannes Hudde and Huydecoper were influential actors in the making of natural historical knowledge and were well integrated into the patronage networks of science.

\section{Politics of Knowledge Systems}

The search for patronage for botanical research meant that natural history projects combined the academic realm with the world of princely rulers and urban elites. The first volume of the Hortus Malabaricus was dedicated to the Governor General Joan Maatsuiker, the second volume to 'his protectors and friends', Gillis Valckenier, Johannes Hudde, Jan Huydecoper, and Pieter van Dam. This is significant as they were influential members of Amsterdam politics and commerce especially Governor General Joan Maatsuiker who was one of the Directors of the Dutch East India Company. Twelve copies were bought by the Lords XVII to share some of the heavy printing expenses. This shows some interest in Van Reede's work in the Republic. But this did not result the VOC taking interest in Malabar medico-botanical knowledge in the later years or by Van Reede's successors. Of the twelve copies, six copies were sent to Batavia and the rest distributed among the various Chambers of the Company. The dedications on different volumes of the Hortus Malabaricus reflect the need for patronage to complete the production of the work. Van Reede then got into an arrangement with Utrecht medical professor Johannes Munnicks, and publishers Pieter 
van Someren, Hendrik Boom and widow of Dirk Boom to fund the remaining volumes of the Hortus Malabaricus. ${ }^{129}$ The different commitments of the participants from different social worlds reflect a fascinating phenomenon - the functioning of mixed economies of information with different values and only partially overlapping coin. ${ }^{130}$

Van Reede dedicated the third volume to the King of Cochin whose court must have facilitated the collaboration with native physicians. In the preface to Volume 3, Van Reede wrote, 'I am impelled to make it known that I am indebted to pay respect to Your Honour (ruler of Cochin) during the whole course of my life...it is for the above reasons that the illustrated work of Malabar plants is offered to Your Majesty'. ${ }^{131}$ This was in the aftermath of the criticism Van Reede received from the Company. Once he realized that the Company administration was unlikely to be forthcoming, he dedicated the work to the Cochin ruler in the hope of getting his support for his further research works in the region. Early modern scientific work reflected the interconnectedness of power, commerce and patronage. The writings of natural history in the sixteenth century, be it from Goa, Burgos, or Amsterdam, meant that the actual publishing and production of any work was contingent on the author's ability to attract local and wider patronage. Though Van Reede's efforts did not secure him or his work the fame he had hoped from the High Government at Batavia or Lord XVII, the Hortus Malabaricus nonetheless became one of the most influential works on Asian botany, with later botanists like Carolus Linnaeus referring to the work in his own research. The afterlife of the Hortus Malabaricus in the eighteenth century will be analysed in detail in the next chapter to see how early modern scientific networks encompassed diverse concerns and ends.

\section{Conclusion}

This chapter has examined how the Hortus Malabaricus fitted into the colonial bio-prospecting efforts, its intellectual and economic milieu; and how a botanical work whose inception in Malabar and conclusion in the Dutch metropolis reflected the nature of knowledge-making in the early European modern period. An examination of the journey of Van Reede and the Hortus Malabaricus illustrates the obstacles the early modern natural history practitioners faced in transporting and diffusing accurate information based on first-hand experience and indigenous knowledge across the ocean during the age of print. There was a fundamental incommensurability between the form

\footnotetext{
${ }^{129}$ It is important to note that the name of the women who contributed to the funding for the publishing of the volumes remained anonymous, they are referred as the 'widow of John van Sommeren' and 'widow of Theodore Boom' in the volumes.

${ }^{130}$ Star and Griesemer, 'Translations and Boundary Objects', pp. 412-413.

131 Van Rheede's Hortus Malabaricus, Vol. 3, p. vii.
} 
of knowledge that Van Reede had compiled in Malabar and the published work in Amsterdam. The studies in colonial science does not fully address the hierarchy involved in heterogenous activity, nor does it do full justice to intergroup politics in various local conditions. Though historians such as Richard Grove and J. Heninger have hailed Van Reede for acknowledging his 'informants', the Hortus Malabaricus is still a story of Dutch supremacy over Malabar botanical information. For Van Reede, Malabar served as a botanical laboratory and a resource for obtaining finances and position for his Company activities. It is a history of how the Company apparatus dominated the political and economic construction of Malabar's botanical knowledge and less a story of colonial botanical collaboration. Even after two hundred years its publication, Alfredo Galletti, an Italian critic and translator, translated the Hortus Malabaricus as the Botany of Malabar. ${ }^{132}$ The format or arrangement of the flora was reworked in a European setting that fitted into the early modern culture of commerce, patronage and science. The Hortus Malabaricus categorized the knowledge of flora in a disciplined European classificatory system; classification and codification of diverse species and population. Later in the eighteenth century, English also used similar forms of classification to understand flora and fauna.

Knowledge-production was not only influenced by accessibility and availability, but also by the political authority of individuals in the colonies and metropolis. The Hortus Malabaricus is a prime example which shows how European observation, description and accumulation of information on nature came to be ever more systematically encountered, catalogued, published, collected and studied. By shedding light on the Hortus Malabaricus, we see the degree of visibility of knowledge produced in the early modern period. By highlighting the different actors of diverse backgrounds who played a role in the production of the Hortus Malabaricus, this chapter combined frameworks from colonial botany, early modern scientific and botanical production and trade and commerce.

The foundations of the Municipal Garden of Amsterdam occurred at a crucial moment in the history of the Hortus Malabaricus and contributed considerably to the success of Van Reede's project. ${ }^{133}$ The historical literature on the Hortus Malabaricus does not reflect on this parallel development of the print and botanical culture of the Republic. This aspect will be developed in the next chapter to show how the botanical knowledge created of the Indies was channelled in various ways in the Republic to further the political agendas of the people involved.

132 Galletti, The Dutch in Malabar, p.2.

${ }^{133}$ Heninger, Hendrik, Adriaan Van Reede, p. 64. 


\section{Chapter Three}

\section{Making Botany: The Hortus Malabaricus in the Dutch Republic, 1680-1750}

\section{Introduction}

The Dutch Republic in the seventeenth century had become a major overseas empire, while it was also acknowledged as a leader in many areas of medicine and natural sciences, partly because of its contacts in Asia. ${ }^{1}$ As discussed in Chapter One, the enthusiasm for gardens and cabinets of curiosities was the direct result of imports of the VOC trade in Asia. The Dutch Republic produced some of the most eminent naturalists of the day - Carolus Clusius, Paul Hermann, Isaac and Jan Commelin and Hendrik Adriaan Van Reede. By the eighteenth century, knowledge about Asian plants and other tropical medicines were in the hands of many. With institutions like the Royal Society of London promoting research and scientific endeavours, surgeons and European officials were actively engaged in buying and selling plants. This chapter further explores the intellectual values of the Dutch information society where the Hortus Malabaricus was edited and printed. This chapter examines the multi-layered process of the spread of natural historical knowledge of the Indies in Europe.

The last chapter examined Van Reede's initiative, the Hortus Malabaricus in Malabar. The Hortus Malabaricus arrived in the Dutch Republic in its manuscript form, with pen and ink drawings and descriptions in Latin, and with plant names in four different languages. When the information moved from Malabar to the Republic, numerous practitioners reworked it within their institutional network and with their expertise in natural history knowledge. The Hortus Malabaricus 'adapted to local needs but maintained a common identity across sites'. ${ }^{2}$ The botany of Malabar was translated, to use Star and Griesemer's phrase, into various media; into print and copperplate engravings; information was copied into other botanical texts, and images were used as visual aids. This translation required developing, teaching and enforcing a clear set of methods to 'discipline' the

\footnotetext{
${ }^{1}$ Harold Cook, Matters of Exchange: Commerce, Medicine and Science in the Dutch Golden Age (New Haven and London: Yale University Press, 2007), p. 3.

2 Susan Leigh Star and James R. Griesemer, 'Institutional Ecology, 'Translations' and Boundary Objects: Amateurs and Professionals in Berkeley's Museum of Vertebrate Zoology, 1907-39', Social Studies of Science, Vol. 19, no. 3, Aug. 1989, p.393.
} 
information collected from Malabar. The parts of the work essential to maintaining coherent information were pooled while others were left alone. ${ }^{3}$ During this process, a synthesis or crossfertilisation of sources occurred. An analysis of the sources will be discussed in the chapter to show that the text became a comparative work for cross-reference to identify plants from other parts of Company settlements like Surinam, Batavia and Cape. Though Malabar as a space of enquiry loses its importance for the Company, Malabar plants became significant in the way tropical flora was imagined in European botanical writings.

The information on tropical plants from the Hortus Malabaricus was disseminated by various practitioners engaged in natural history. While surgeons and naturalists in London referenced it in terms of its usefulness for collecting naturalia and medicinal plants from their English settlements in India, gardeners and travellers used it for gathering specimens for their newly emerging municipal gardens. Naturalists like Maria Sybilla Merian deployed it for identifying the plants that she came across in another Dutch colony, Surinam. Book publishers and artists had more authority over the visual medium of transfer. The colonial understanding of the scientific development was rooted in the idea that native knowledge was 'unscientific'. Recent works have shown how Western science was often relocated and domesticated as an Indian intellectual experience. ${ }^{4}$ In the Indian Ocean world, specialised knowledge relating to botany, medicine and alchemy was formalised and in circulation from the Arabian Peninsula to China within specialised communities before the competitive European trade in spices began. ${ }^{5}$ Local knowledge became increasingly drawn together in an ever-thickening network of exchange in the early modern period. Works by Steven J Harris, Peter Burke and David N. Livingstone formulate approaches to understand the new geography of knowledge in this period. ${ }^{6}$ By drawing insights from these studies, this chapter will examine the reception and impact of the Hortus Malabaricus on Dutch botanical science, especially how it was represented in European works of natural history.

While discussing the history of imperial science, Kapil Raj has argued that naturalists and physicians such as Orta, da Costa, Van Reede, Hermann and Rumphius gained their credibility not from providing information to European armchair savants, but by making and circulating knowledge through negotiations with local Asian groups. ${ }^{7}$ This argument comes from the limited survey of the influence the Hortus Malabaricus had in Europe and other colonies of the Dutch

\footnotetext{
${ }^{3}$ Ibid.

${ }^{4}$ Dhruv Raina and Irfan S. Habib, Domesticating Modern Science: A Social History of Science and Culture in Colonial India (New Delhi: Tulika Books, 2004).

${ }^{5}$ Kapil Raj, Relocating Modern Science: Circulation and the Construction of Knowledge in South Asia and Europe, 1650-1900 (London: Palgrave Macmillan, 2007), p.30.

${ }^{6}$ Arndt Brendecke and Susanne Friedrich, 'Introduction' in Susanne Friedrich, Arndt Brendecke, Stefan Ehrenpreis (eds). Transformations of Knowledge in Dutch Expansion (Berlin and Boston: Walter de Gruyter, 2015), p.2.

${ }^{7}$ Raj, Relocating Modern Science, p. 58.
} 
Republic like the Cape in the eighteenth century. The extant historiography has focused on how the Hortus Malabaricus had an impact on post-Linnaean taxonomy. But analysis of the influence of the Hortus Malabaricus on botanical and natural history works (which historians have failed to examine) tells a different story. Its influence on European plant knowledge was not limited to its content, but was manifested in imitation of its template, form, narrative, illustrations, drawings, classification, title page, and commentary in other works of natural history produced in this period. While the level of representation from the Hortus Malabaricus differed, a cross-fertilisation of European botanical works occurred, demonstrating that the descriptions and medicinal properties in the Hortus Malabaricus took prominence over other forms of its representation. The natural history from the Hortus Malabaricus did not directly translate to bringing seeds or living specimens to the Dutch Republic, but instead the Hortus Malabaricus acted as a reference catalogue for identifying plants from the VOC settlements.

In this context, this chapter will examine the role of the Hortus Malabaricus in influencing the development of botany in the Dutch Republic. The chapter will focus on the development of botanical gardens, especially the Amsterdam Botanical Garden, the reproduction of illustrations from the Hortus Malabaricus in other natural history works and its role as a reference book of Asian botany. To examine how different naturalists and botanists played a role in the dissemination of plant knowledge from the Hortus Malabaricus, the text will be treated as a natural history work 'which is both plastic enough to adapt to local needs and constraints of the several parties employing them, yet robust enough to maintain a common identity across sites. ${ }^{8}$

\section{From Hortus Medicus to Hortus Botanicus: Botanical Gardens in the Republic}

Between the archive and the field, the world of museum and the world of nature stands the garden. ${ }^{9}$

Botanical gardens became part of the institutional culture of science in Renaissance Europe. Private botanical gardens flourished in the early sixteenth century not only as 'physick gardens' filled with medicinal plants, but also as pleasure gardens of the nobility and urban elite. ${ }^{10}$ A steady stream of published herbals in the 1530s and 1540s, all lamenting the imperfection of botanical

\footnotetext{
${ }^{8}$ Star and Griesemer, 'Institutional Ecology, “Translations” and Boundary Objects', pp.387-420.

${ }^{9}$ David N. Livingstone, Putting Science in its Place: Geographies of Scientific Knowledge (Chicago and London: The University of Chicago Press, 2003), pp.48-49.

10 Paula Findlen, 'Anatomy Theaters, Botanical Gardens, and Natural History Collections' in Katherine Park \& Lorraine Daston (eds.), The Cambridge History of Science (Cambridge: Cambridge University Press, 2006), p. $272-289$.
} 
knowledge, made it clear how botanical studies were still at infancy. ${ }^{11}$ Gardens became microcosmos of new plants and empires in that European companies created overseas. Sunflowers from Peru, tulips from the Levant, corn, potatoes, tomatoes tobacco and hundreds of other plants from the Americas transformed the botanical garden into another Eden, combining the medicinal herbs of the ancient Mediterranean described in Greek and Roman pharmacopoeias, with the wonders of newly discovered nature that came from the Americas and elsewhere. ${ }^{12}$ This section will explore the significance of understanding the space or geography in which knowledgeproduction took place, and it will help place the intellectual and material environment in which the Hortus Malabaricus was received.

Once freed from the clutches of medicine, botanical gardens could now include a wide array of plant varieties, which added to the craze for empiricist observation developing in Europe at the time, and which also reflected increased access to new plants following the expansion of international trade. Botanical gardens became sites in which a new kind of medical professor, the professor of botany (or medicinal herbs), could demonstrate the nature and virtues of plants to students of medical science. In this sense, gardens eventually became botanical research facilities in which scholars who sought to understand the plant as both natural and medical object worked on morphology and classification. Botany professors exchanged plants with other learned botanists, physicians and apothecaries, to keep their gardens full and varied and to please princely patrons and overseas merchants, who were the other significant sources of new plants. ${ }^{13}$ Botanical gardens facilitated global plant transfers. It was in the process of the transfer of plants across very diverse ecological and social contexts, that natural history was transformed into a formal science in both India and Europe. ${ }^{14}$ Gardens not only established the developing cities as learning centres in Europe, but also facilitated the mobility of plants and people, profit and patronage as indispensable ingredients of the new science of botany. ${ }^{15}$ An apt example of this is the Amsterdam Botanical Garden.

Historian of science Harold Cook argues that the early lead of the Dutch in botanical studies was owing to the intellectual developments in the Netherlands as well as its early commercial and political dominance in Asia (compared to English). ${ }^{16}$ Stimulated by a powerful

\footnotetext{
${ }^{11}$ Findlen, 'Anatomy Theaters, Botanical Gardens, and Natural History Collections', p. 272.

12 Ibid. p. 281.

13 Ibid, p.282.

14 Zaheer Baber, 'The Plants of Empire: Botanic Gardens, Colonial Power and Botanical Knowledge', Journal of Contemporary Asia, Vol. 46, no.4, 2016, p.659.

${ }^{15}$ See Richard Drayton, Nature's Government: Science, Imperial Britain and the 'Improvement' of the World (Yale: Yale University Press, 2000) and Baber, 'The Plants of Empire'.

${ }^{16}$ Harold Cook, 'Natural History and Seventeenth century Dutch and English medicine' in Hilary Marland and Margaret Pelling (eds.), The Task of Healing, Medicine, Religion and Gender in England and Netherlands, 1450-1800 (Rotterdam: Erasmus Publications, 1996), pp.253-257.
} 
combination of medical interests and enthusiasm for exotic garden specimens, Dutch investigations of the natural history of Asia and Africa became renowned in the late seventeenth century. ${ }^{17}$ In the Netherlands, with the development of the botanical gardens of Leiden, Amsterdam, Breda and Utrecht and with the activities of Jacobus Bontius, ${ }^{18}$ attempts were made to grow some species of plants from the Indian archipelago, such as Biophytum sensitivum (the Touch-me-not) and Bambusa arundinacea (Indian Bamboo). ${ }^{19}$ Plants found their way into gardens of Europe in a commercial context, in which the exotic made quick money, through its association with status, prestige and patronage. By the seventeenth century, collections of rare exotic plants were a source of national pride and were significant in advancing medicinal knowledge. For instance, in 1620, Louis XIII's Parisian Jarden Royal des Herbes Médicinales was established for surpassing all other European botanical gardens. This garden was intended for therapeutic botany and the arrangement of plants reflected the medicinal order by physician Jacques Dalechamps (1513-88). But by the eighteenth century, this classification based on medicinal properties was deemed outdated by the arrival of new plants, most notably quinine from the Cinchona tree (Cinchona officinalis L.) that arrived from Peru in the 1630s, commonly called Jesuit powder. ${ }^{20}$ Once physicians found that quinine could be used to treat malarial fevers, it encouraged the idea that there could be more specific remedies in foreign plants for certain diseases.

Similarly, during the seventeenth century, the VOC trade in plant materials and natural exotica is the prime reason for the increased availability of plants in Europe. ${ }^{21}$ In July 1660, the VOC share price in the Amsterdam Exchange rose from 370 to 480 pounds (Fl.). ${ }^{22}$ A direct result of this expansion was that the gardens were no longer filled with medicinal herbs that were long known from ancient Greek and Roman pharmacopoeia. Now, they also housed plant varieties from abroad. It was mostly due to the efforts of individuals working for the VOC that exotic plants flourished in the Republic. Although botanical exploration was being undertaken in many parts of the world, almost no reliable information was available on South or Southeast Asia so that, with the Hortus Malabaricus, Van Reede could fill that huge gap in knowledge at a stroke. By establishing himself as author of a work of Malabar botany, Van Reede brought a huge volume of

\footnotetext{
${ }^{17}$ Harold Cook, Matters of Exchange: Commerce, Medicine and Science in the Dutch Golden Age (New Haven and London: Yale University Press, 2007), p. 304.

${ }^{18}$ Jacobus Bontius received his doctor's degree from Leiden University (and worked in Java). His medical observations were published posthumously as De Medina Indorum in 1642. See, J. Heninger, Hendrik Adriaan van Reede tot Drakenstein (1636-1691) and Hortus Malabaricus: A contribution to the history of Dutch colonial botany (Rotterdam and Boston: A. A. Balkema, 1986), p. 44.

${ }^{19}$ Cook, Matters of Exchange, p.12.

${ }^{20}$ Roger L. Williams, Botanophilia in Eighteenth-Century France: The Spirit of the Enlightenment (Dordrecht and Boston: Kluwer Academic Publishers, 2001), p.42.

${ }^{21}$ Steven J Harris, 'Long-distance corporations, big sciences, and the geography of knowledge' in Sandra G. Harding (ed.), The Postcolonial Science and Technology Studies Reader (Duke: Duke University Press, 2011), p.358.

22 Jonathan Israel, Dutch Primacy in World Trade 1585-1740 (Oxford: Clarendon Press, 1989), p.255.
} 
information of around 720 plants to Republic. Together with the Herbarium Amboinense of Georg Eberhard Rumphius (1628-1702), the Hortus Malabaricus established Holland as the centre of tropical botany. ${ }^{23}$ During overseas trade and the establishment of colonies, the need for producing food led to the development of intensive market gardening in insular settlements like the Cape of Good Hope, Batavia and Malabar. This led to the subsequent establishment of botanical gardens, like the one at Cape Town in 1654. One objective of such a garden was the acclimatisation of plants and trees from other regions for providing food and timber for shipbuilding and repair. ${ }^{24}$ Thus the gardens were not specifically created for expanding botanical knowledge but as "commercial" gardens.

The VOC settlement at the Cape acted as a victualling point en route to and from Europe. Thus, the need for a Company garden was logical. The garden became the testing ground for seeds, roots and plants from the Netherlands and throughout the VOC's commercial networks. Furthermore, the climate of the Cape settlement was ideal for introducing the plants brought from Asia. ${ }^{25}$ Commerce and cultivation went together with the expanding understanding of the natural and geographical knowledge of the Company settlements. Alette Fleischer, in her study of the VOC activities in the Cape, argues that natural scientific production was an integral part of the Company's commercial activities. ${ }^{26}$ By engaging in the establishment of the garden, naturalists and botanists also conducted research on plants procured in the Cape settlement. The VOC was not sponsoring scientific activities, but its staff stationed at the ports turned these settlements into research stations. This attracted naturalists to study indigenous flora and to promote intercontinental plant transfer.

\footnotetext{
23 Richard Grove, 'Indigenous Knowledge and the Significance of South-West India for Portuguese and Dutch Constructions of Tropical Nature', Modern Asian Studies, Vol. 30, no.1, 1996, p.140.

${ }^{24}$ Kapil Raj, '18th-Century pacific voyages of discovery, "big science", and the shaping of an European scientific and technological culture,' History and Technology, an International Journal, Vol. 17, no. 2, 2000, p. 89.

${ }^{25}$ Richard Grove, Green Imperialism (New York: Cambridge University Press, 1995), p. 126.

${ }^{26}$ Alette Fleischer, 'The Company's Garden and the (Ex)change of Nature and Knowledge at Cape of Good Hope (1652-1700)' in Lissa Roberts (ed.) Centres and Cycles of Accumulation in and around the Netherlands (Muenster: LIT Verlag, 2011), p.104.
} 


\section{Leiden Botanical Garden}

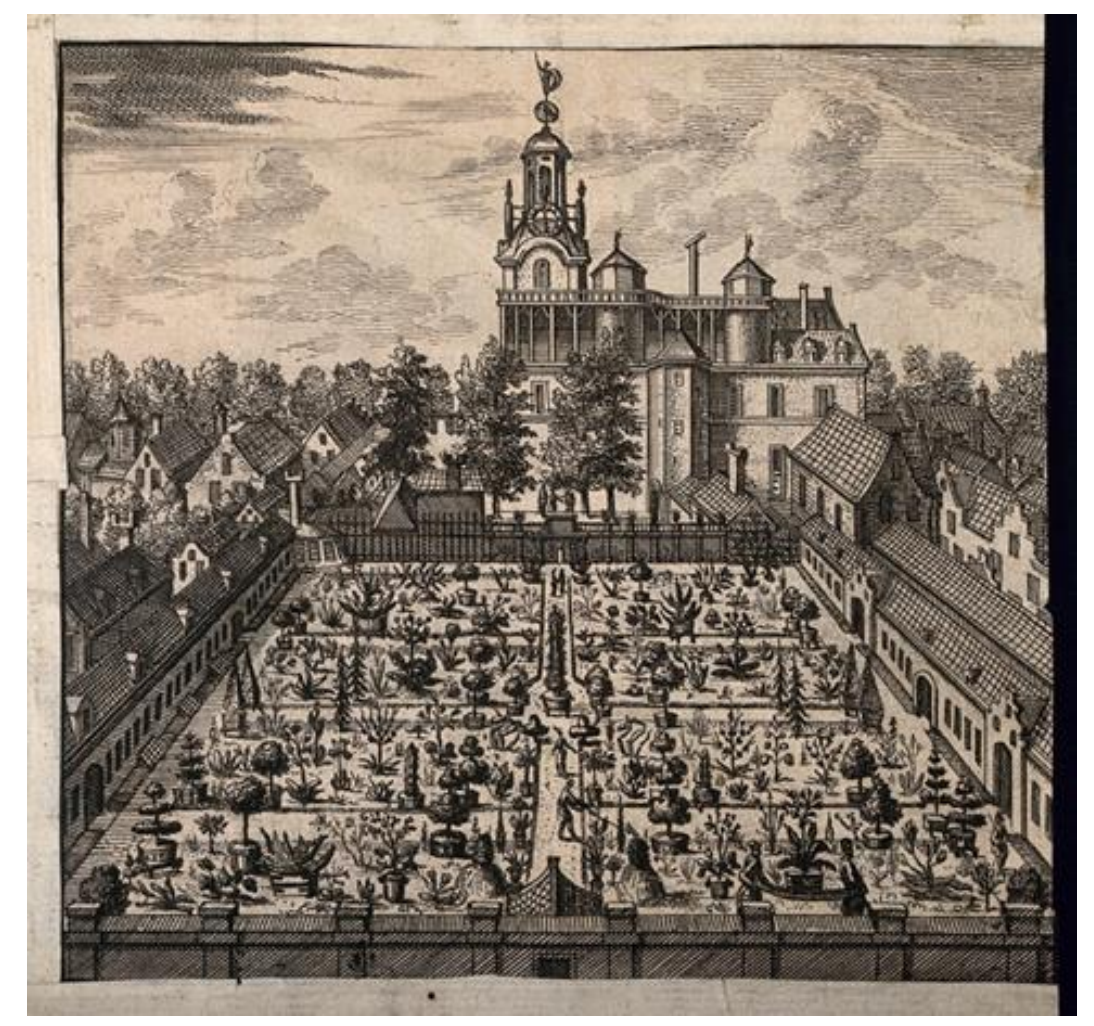

Fig. 9. Drawing of the Leiden botanical garden (Courtesy: Wellcome Collection)

But how a glorious day it was when a rare exotic plant flowered! ${ }^{27}$

From the middle of the sixteenth century, a marked increase and shift to empirical studies took hold of faculties across Europe, from Bologna to Oxford and Montpellier to Leiden. ${ }^{28}$ The shift towards the direct examination and sensory appreciation of subjects of study, anatomical theatres and gardens became prized possessions of medical faculties throughout Europe. Different institutions were indispensable for the realisation of imperial ambitions and the consolidation of trade routes and territory in the early modern and modern periods. This led to the development and entrenchment of scientific knowledge, practices, and institutions in the process of imperial and commercial development. Institutions such as universities and publishing houses were

\footnotetext{
${ }^{27} \mathrm{~J}$. Heninger, 'Some Botanical Activities of Herman Boerhave, Professor of Botany and Director of the Botanic Garden at Leiden', Janus, Vol. 58, no. I, 1971, p. 17.

${ }^{28}$ Claudia Swan, 'Medical Culture at Leiden University ca. 1600: A Social History in Prints,' Nederlands Kunsthistorisch Jaarboek, Vol. 52, 2002, p. 217.
} 
instrumental in the production and dissemination of knowledge. For instance, Leiden University grew from an idea to an institution of international stature within two decades of its establishment. From the outset, medicine was one of the four faculties in which instruction was offered, along with theology, jurisprudence, and philosophy. ${ }^{29}$

Leiden University established a hortus in the mid-1590s and locus anatomicus (anatomy theatre) by 1610; both were celebrated nationally and across Europe. The University of Leiden appointed a professor of botany just two years after the establishment of the university (1575). ${ }^{30}$ The Leiden garden and anatomical theatre answered the need for hands-on instruction in medicine that characterized the latter half of the sixteenth century. The importation of exotic plants, network of giardini dei semplici and praefecti horti (gardens of simples and curators of physic gardens) became most evident at the Hortus Academicus, Leiden, which became a repository for plants brought to Holland by the VOC. According to historians of the botanic gardens Roger Spencer and Rob Cross, the Leiden Botanic Garden under Clusius (Director 1593-1609) was probably among the first in the early modern period to grow plants for their ornamental interest rather than solely their medicinal use. In other words, 'made a true hortus botanicus rather than a hortus medicus. ${ }^{31}$

Italian physicians and botanists like Caspar Bauhin and Prosper Alpinus, as well as Dutch botanists like Willem Piso and Jacobus Breynius, were the first Europeans to study Malabar flora. ${ }^{32}$ Carolus Clusius, botanist and the first prefect of the Leiden garden, simplified garden design by creating four quadrants to represent the four continents (Europe, Asia, Africa and America), each divided into sixteen beds (see fig. 9). ${ }^{33}$ He organized plants by species rather than their medicinal use, reflecting a shift in the status of botany as a field of study independent from medicine. ${ }^{34}$ Through the medium of trade, the Leiden garden and, from 1682, the Amsterdam garden, cultivated plants from the Indian archipelago, Ceylon, Malabar and South Africa. As well, the West India Company supplied plants from South America via Surinam. As new plants arrived from the Indies, they were identified, named and allotted their places in the garden's spatial taxonomy. The Company gardeners also practised this method of laying out plants in continental categories. For instance, in 1686, a French traveller to the Cape noted that the VOC garden was arranged in

\footnotetext{
${ }^{29}$ Claudia Swan, 'Medical Culture at Leiden University', p.217.

${ }^{30}$ J. Heninger, 'Some Botanical Activities of Herman Boerhave', p. 17.

31 Roger Spencer and Rob Cross, 'The origins of botanic gardens and their relation to plant science, with special reference to horticultural botany and cultivated plant taxonomy', Muelleria Vol. 35, 2017, p.57.

32 Pratik Chakrabarti, Materials and Medicine: Trade, Conquest and Therapeutics in the Eighteenth Century (Manchester and New York: Manchester University Press, 2010), p.112. Also, in 'An Account of Some Books', Philosophical Transactions of the Royal Society of London, Vol. 13, 1683, p.100.

33 Wellcome Collection, https://wellcomecollection.org/works/hgjbsn9w accessed March 2019.

${ }^{34}$ Findlen, 'Anatomy Theatres, Botanical Gardens', p. 283.
} 
compartments, with each displaying rare fruit-bearing trees from Asia, Africa, Europe and America. ${ }^{35}$

The VOC officials also collected plants during their tenure overseas for their own private gardens. For instance, Hendrick Munting, who served as a VOC officer in the Cape and Batavia, had a private garden at his residence at Groningen that was so renowned for its specimens that the Groningen Government in the Republic placed it under its protection. Moreover, the Government also granted subsidies for its maintenance, and awarded Munting the title of botanist of the Province - a responsibility that included delivering lectures within the garden. ${ }^{36}$ In 1659 , Englishman Sir Thomas Hamner commented on the demand for botanical gardens to contain 'rarities the French and the Dutch have for some years been most diligent enquirers, and collectors [of], as the Italians and Germans before them [were] in procuring the rarest flowers and plants'. ${ }^{37}$ In the wake of the trade in the Indies, the conception of the garden as a hallowed refuge from the world began to be supplemented by a vision of the garden as a living encyclopaedia. ${ }^{38}$

The developments within the Netherlands boosted the relationship between commerce and science. Dutch instrument makers invented scientific instruments for observing nature, and techniques for marketing these instruments. Innovations in greenhouse technologies made oranges and pineapples available in the Netherlands - these were effectively hothouses that permitted tropical fruits to grow well beyond their climatic zones. ${ }^{39}$ Heninger writes that it was at times challenging to maintain tropical plants. A severe winter in Holland could damage many outdoor plants, and unsuccessful fructifications caused annuals and biennials to die out. ${ }^{40}$ The garden had its greenhouse, winter gallery, and hothouse, although owing to lack of space, only the most delicate plants could be kept in this refuge. Another example of the commerce-botany nexus was the story of Jan Commelin who had established himself as a famous garden writer, with the publication of The Belgick, or Netherlandish Hesperides (1676), a book on growing citrus fruits in the Republic (see fig.10). ${ }^{41}$

Commelin was also the editor of volumes 2-12 of the Hortus Malabaricus. Commelin was an apothecary and a merchant in Amsterdam who rose to prominence in his role as the first Co-

\footnotetext{
35 Alette Fleischer, 'Exchanging Knowledge and Nature (Cape of Good Hope)' in Siegfried Huigen, Jan de Jong and Elmer Kolfin (eds.), The Dutch Trading Companies as Knowledge Networks (Leiden and Boston: Brill, 2010), p.251.

${ }^{36}$ John Claudius Loudon, An Encyclopedia of Gardening Comprising the Theory and Practice (London: Spottiswoode, 1835), p.70.

37 Thomas Hamner, (1659), Ivy Elstob (trans.) and Eleanour Sinclair Rohde (eds.), The Garden Book of Sir Thomas Hamner Brat (London: Gerald Howe, 1933), pp. xvii-xviii.

${ }^{38}$ Livingstone, Putting Science in Its Place, p.49.

${ }^{39}$ Dániel Margócsy, Commercial Visions: Science, Trade and Visual Culture in the Dutch Golden Age (Chicago and London: The University of Chicago Press, 2014), p. 16.

${ }^{40}$ Heninger, 'Some Botanical Activities of Herman Boerhave', p.17.

${ }^{41}$ The Leiden Botanical Garden Orangery, Fagel Orchids and Orangeries Collection, No. Fag. M. 4. 40. The Library of Trinity College, Dublin.
} 
Director of the Amsterdam Botanical Garden along with Joan Huydecoper. Typical of the times, at least amongst the wealthier and growing middle class, Commelin operated a sizeable importing business in pharmaceuticals, supplying many apothecaries in Amsterdam and Gouda. He also owned a botanical garden on his estate, Zuyderhout. ${ }^{42}$ On 22 May 1692, the Dutch newspaper Amsterdamse Courant advertised the sale of trees and plants left on the estate following the death of Jan Commelin:

Next Thursday, June 5, at 2 o'clock in the afternoon, a sale will be held outside Haarlem at the end of Groote Hout, on the estate known as Zuyderhout, of the oranges, lime, myrtle and other trees and plants left by the late Mr. Commelin, who was on the council and supervisory board of Hortus Medicus of the city of Amsterdam. ${ }^{43}$

The manner in which plants were obtained from Dutch settlements and the way in which they revolutionised the botanical gardens in the Republic can be best illustrated in the case of Amsterdam.

\footnotetext{
${ }^{42}$ Dirk Onno Wijnards, The Botany of Commelins (Rotterdam: A. A. Balkema, 1983), p. 9.

43 Amsterdam Courant, May 22, 1682 (second page) accessed online on 23 June 2020 at https://www.kb.nl/en/organisation/research-expertise/digitization-projects-in-the-kb/database-of-digital-dailynewspapers, (Koninklijke Bibliotheek (KL)), Hague, The Netherlands.
} 


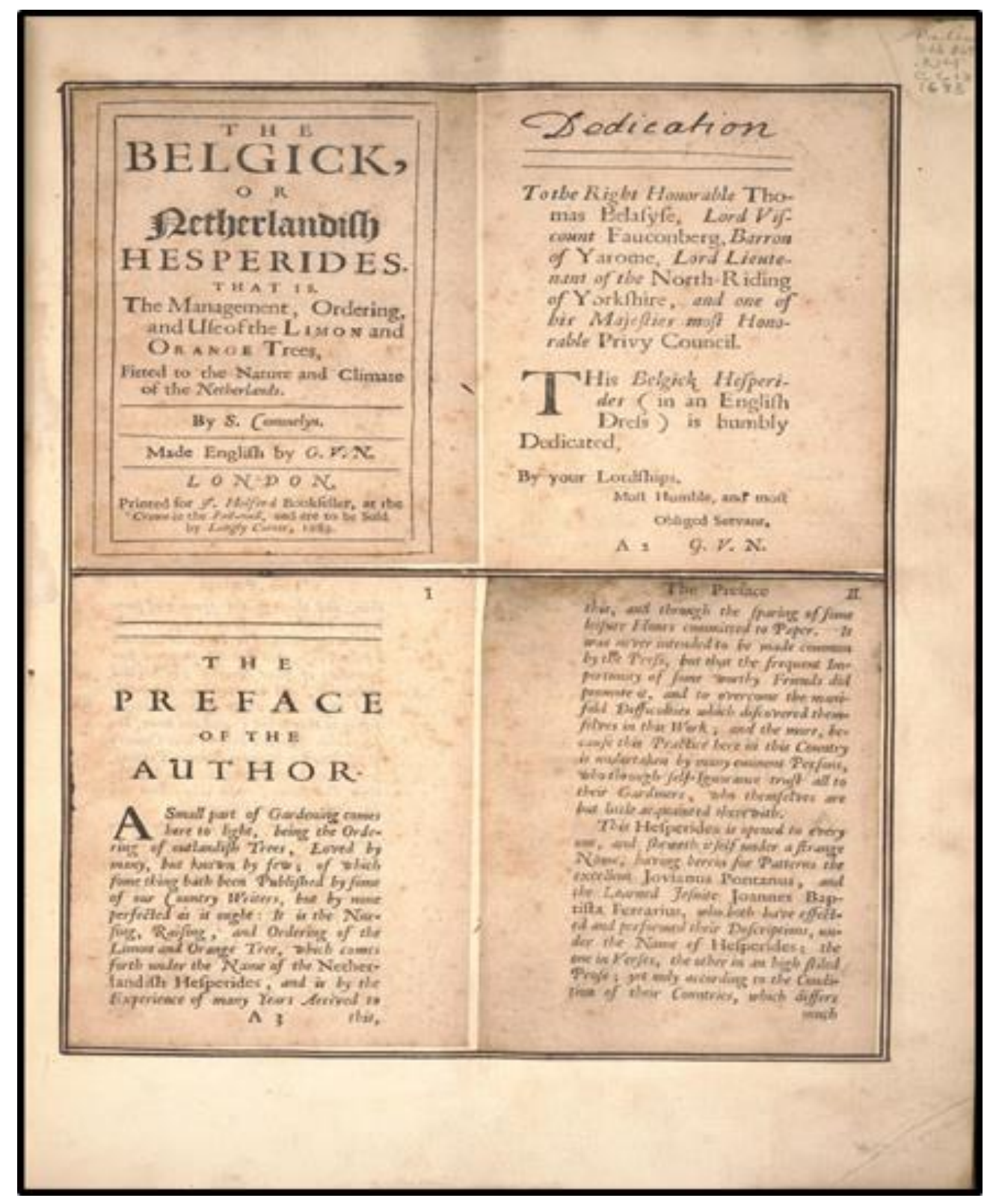

Fig. 10. Page from Jan Commelin's, The Belgick, or Netherlandish hesperides (1676) 


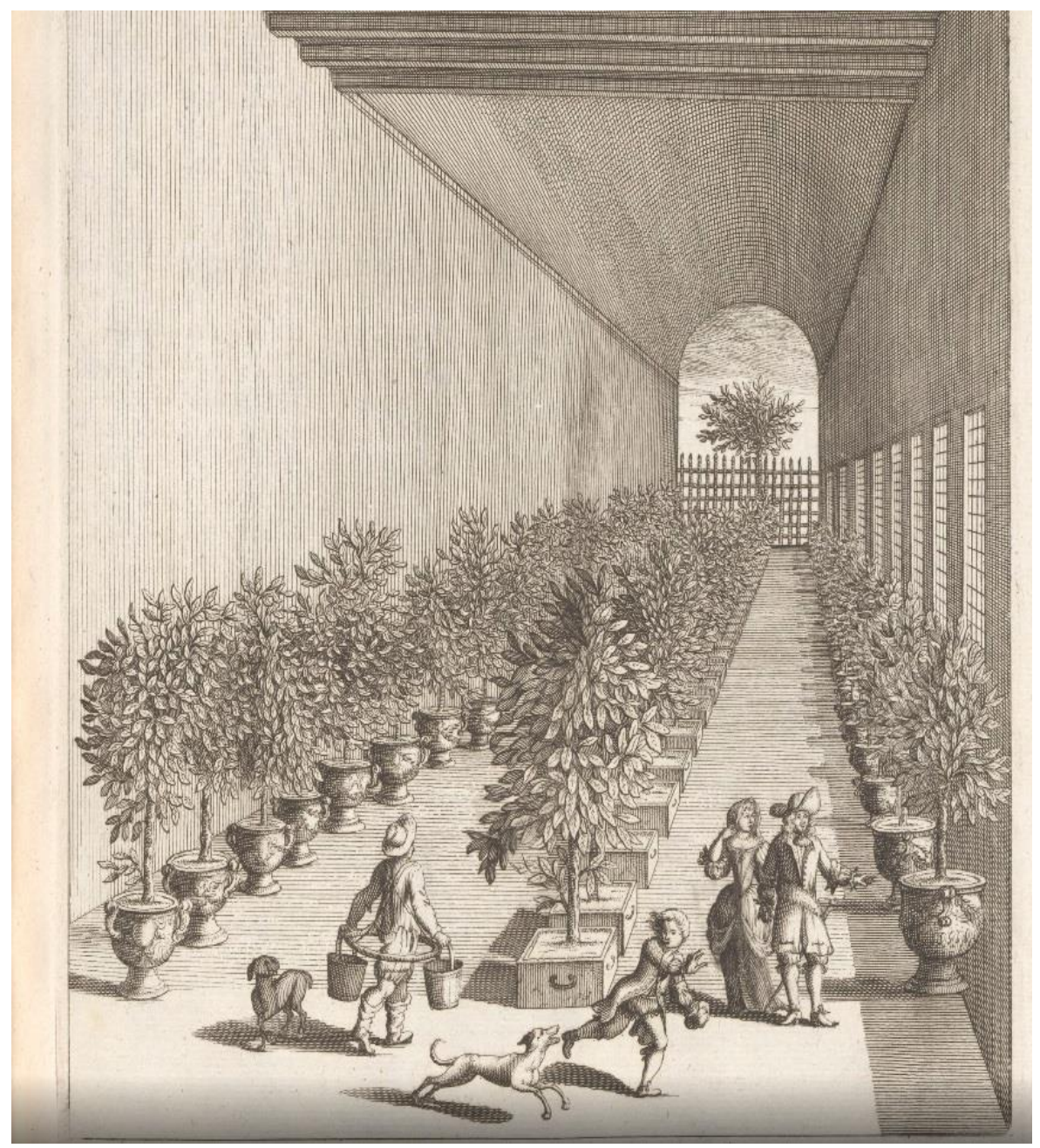

Fig. 11. Orangery in Leiden academic building (Courtesy: Library of Trinity College, Dublin)

\section{Amsterdam Botanical Garden}

The Hortus Medicus of Amsterdam was established by the Amsterdam city council on 12 November 1682. In January 1682 the town council approved a plan to rent plots to Amsterdammers who wished to lay out gardens. The Plantage committee set up to oversee this plan included Joan Huydecoper and Jan Commelin. ${ }^{44}$ Huydecoper was one of the seventeen Directors of the Dutch East India Company since 1666 and had long been using his influence to collect exotics from the Indies. As already mentioned in the previous chapter, Van Reede had close association with Huydecoper and Commelin. On behalf of the new Plantage committee, Huydecoper submitted a proposal to the town council, arguing that a botanical garden would serve not only doctors and apothecaries but also beautify the city. He further proposed to build an orangery, as well as accommodation and a public house to serve refreshments to visiting

${ }^{44}$ Luuc Kooijmans, Death Defied: The Anatomy Lessons of Frederik Ruysch (Leiden and Boston: Brill Publishers, 2010), p.163. 
dignitaries. An amount of 10,000 guilders was estimated for the plan. ${ }^{45}$ Huydecoper proposed that the annual expenses, such as the gardener's salary and the necessary maintenance, would be met with the sale of plants to physicians, apothecaries and other interested parties. Candidates for the apothecary's examination would be required to contribute to the botanical garden. Apothecaries' assistants would be allowed to visit it twice a week for an annual fee of one guilder. Quacksalvers who paid a fee to the surgeons' guild for the right to have a stall at the annual fair or the weekly market, would be asked to contribute an equal amount to the botanical garden. The proposal also stated that the public would be charged an entrance fee. In January 1683, Huydecoper and Commelin were appointed to the garden's supervisory board. That spring, when Huydecoper sent drawings of Cape flowers to the botanist Jacob Breijne in Danzig, he shared the news of the garden: 'The city of Amsterdam has had a hortus medicus laid out, with an orangery 130 feet long. Mr Commelin and I have been appointed its supervisors. ${ }^{146}$

The Amsterdam gardeners tried to acclimatize commercial plants from the East (such as camphor, cinnamon and tea) and the West Indies (such as pineapple). From there, plants were sent for cultivation to other parts of the Republic. Plant species arrived from the VOC establishments of Japan, Surat, Bengal, Ceylon, Cape Town, Surinam and South America to the garden. ${ }^{47}$ Until now, historians have argued there is no evidence of any Malabar plant specimens that had reached the republic. ${ }^{48}$ One of the reasons for this could be that the plant specimens from Malabar were either taken to Batavia or Cape first, before they reached Amsterdam. For example, the ship Vrijburg left Ceylon on 25 December 1703 with cargo for Amsterdam, and was recorded to have arrived in the Cape (that acted as a victualling settlement) on 9 March 1704 and then left for the Netherlands on 30 August $1704 .{ }^{49}$ During this period, the plant specimens were probably grown in the Company gardens at the Cape before they were taken to Amsterdam. As a consequence of that, the catalogue identified the plants as arriving from the Company garden of the Cape. At the same time, a report of the Royal Society of London (in 1683) mentions:

our author (of Hortus Malabaricus) gives an account of a rare Plant which he calls Kaida whereof there are several sorts which kinds of Ananas are, which our travellers know by the name of Indian Pine-Apples and he sets forth among others a curious Shrub called

\footnotetext{
${ }^{45}$ Kooijmans, Death Defied, p.163.

${ }^{46}$ Ibid.

${ }^{47}$ D. Onno Wijnands, 'The Hortus Medicus Amstelodamensis- its role in shaping taxonomy and horticulture', The Kew Magazine, Vol. 4, no. 2, May 198, p.83.

48 Also argued by Cook in, Matters of Exchange and Heninger in, Hendrik Adriaan van Reede.

49 Database of VOC voyages, knaw.nl. accessed online on 6 June 2020 http://resources.huygens.knaw.nl/das/detailVoyage/96997
} 
Nandi-Eravatam major and minor bearing large odoriferous flowers...one whereof was brought over and presented to the Prince of Orange [Netherlands] and did if not doth grow in his garden at Honsteleardick which our Annotatour calls Syringa Malabariensis lactescens flore niveo pleno odoratissimo. ${ }^{50}$

This citation is interesting as it contradicts the findings of Heninger and Cook, both of whom concluded that no plant specimens from Malabar reached Amsterdam. Though no definite conclusion can be drawn from the commentary above, the chances of specimens reaching the Netherlands from Malabar cannot be entirely dismissed. A much less likely scenario is that the VOC officials working in Malabar did not manage to identify the plants that Van Reede and his team had so carefully detailed and described in the drafts of the Hortus Malabaricus. This interpretation is a possibility, given that the Company or the Board of Directors did not seem to have understood the significance of the medicinal plants of Malabar, nor were they willing to fund botanical expeditions in a region like Malabar which by the end of the seventeenth century was not very profitable in the spice trade.

The VOC sometimes also restricted the cultivation of plants, as it would have weakened its monopoly in trade in the domestic markets. The VOC also tried withholding information of the plants from rival companies, and in some cases, made sure the plants did not reach the Republic. For instance, on his way from Ceylon to Amsterdam, Van Goens made a stopover at the Cape to destroy the cinnamon trees to keep the monopoly of cinnamon trade from Ceylon intact. ${ }^{51}$ When English physician Tancred Robinson (the son of an English merchant in Turkey) visited English naturalist John Ray in 1686, he reported that, to maintain their monopoly, Arab traders sold only infertile coffee beans to foreign customers. He added that they (Arabs) were careful in destroying the coffee seeds by boiling or burning, just as the Dutch in the Moluccas destroyed their nutmeg plants. ${ }^{52}$

In early 1684, Huydecoper wrote to Commelin about the garden's funding, saying he thought it was vital to discuss the matter with Burgomaster Hudde, who was the Consul and Senator of the city of Amsterdam (the patron of both men). The collaboration of Huydecoper, Commelin and Hudde is significant as these men played a significant role in the transformation of the city of Amsterdam as the centre of commerce and botany, with the emerging botanical garden that housed plant varieties from all over the world. Their association to create something for the

\footnotetext{
${ }^{50}$ Commentary on the First Three Volumes of Hortus Malabaricus (author unknown), Philosophical Transactions of the Royal Society of London, 1683, pp.105-106.

${ }^{51}$ Harold Cook, Matters of Exchange, p.320.

52 Margócsy, Commercial Visions, p.51.
} 
city or for public interest marks a shift from their collections in the sixteenth century for their private gardens and cabinets. Historian of science Vera Keller argues that there was a shift in the understanding of scientific knowledge in early modern Europe. The ways in which knowledge was pursued and justifications for pursuing knowledge became more collaborative in nature with public interest in mastering Nature. ${ }^{53}$ Dirk Wijnards notes that one of the scientific projects run at the garden was the editing of Van Reede's Hortus Malabaricus by Commelin. ${ }^{54}$ It is likely that Commelin, as editor of the Hortus Malabaricus, was instrumental in introducing Malabar plants into the Amsterdam botanical garden. In this context, projects like the development of Amsterdam Botanical Garden and the Hortus Malabaricus were furthered as endeavours for public interest in mastering nature. In a compelling study of Westminster Bridge in London, Alison F. O’ Byrne argues that, in the eighteenth century, public projects were undertaken to create public spaces that were 'polite, enlightened and commercially and scientifically modern'. ${ }^{55}$ The development of Amsterdam Botanical Garden is a prime example. These endeavours were also undertaken for the furthering of political agenda of the individuals involved in the body politic of the Republic. As discussed in the previous chapter, Van Reede dedicated the volumes of Hortus Malabaricus to different nobles for patronage. Here, it is significant to see the dedication in Volume 2 of the Hortus Malabaricus,

to the most Noble and Distinguished Lords Joan Hudde and Joan Huydecoper.......this second part (vol.) has been compiled and arranged in that region whereby good administration Your Excellencies are zealous in promoting its prosperity with more than ordinary diligence.....and to acknowledge it in honour of Your Excellencies as my patrons and friends and in token of my gratitude, if not by the rarity of Indian plants, certainly for the reason that I have been persevering at it, Most Noble and Distinguished Lords. I remain your Excellencies' most humble and devoted servant. ${ }^{56}$

One can assume that Van Reede hoped to achieve the status of a metropolitan savant like Commelin. He hoped to contribute significantly to the Republic through his knowledge of Malabar. Mercantile and scientific interests and partnerships between the merchants and the City

\footnotetext{
${ }^{53}$ Vera Keller, Knowledge in the Public Interest, 1575-1725 (Cambridge: Cambridge University Press, 2015).

${ }^{54}$ Wijnards, 'The Hortus Medicus Amstelodamensis', p.87.

55 Alison F. O’ Byrne, 'Composing Westminster Bridge: Public Improvement and National Identity in EighteenthCentury London' in Maximillian E. Novak, ed., The Age of Projects (Toronto: University of Toronto Press, 2008), p.246.

${ }^{56}$ Van Rheede's Hortus Malabaricus English Edition With Annotations and Modern Botanical Nomenclature, Vol. 2, 'Dedication' by K. S. Manilal (Thiruvananthapuram: Kerala University Press, 2003), (not paginated).
} 
Council was a successful form of social exchange: status was accrued in both directions: to both the giver of exotic goods and to the recipient. ${ }^{57}$ The garden became a symbol of national pride and hub of East Indies plants in Europe. This is not to conclude that all the individuals behind the establishment of botanical garden had a common interest in public good. Personal motives clearly drove agendas. After serving as the editor of the volumes 2-11 of the Hortus Malabaricus, Commelin became known as a botanist. He had started as a gardener and trader of East India plants, but wished to project himself as a learned botanist. This is evident from the portrait he commissioned (see fig. 12) where he has dressed himself in a Japanese gown (typical of the style of wealthy gentlemen burgers) surrounded by books on botany, dried plant specimens and a bust of ancient Greek philosopher Theophrastus (known as the father of botany). ${ }^{58}$ His interest in being seen and remembered as a learned gentleman and botanist of the period is evident in his involvement in the Hortus Malabaricus and botanical garden. ${ }^{59}$ Jan Commelin achieved what Van Reede hoped to realise through his labour in the Hortus Malabaricus.

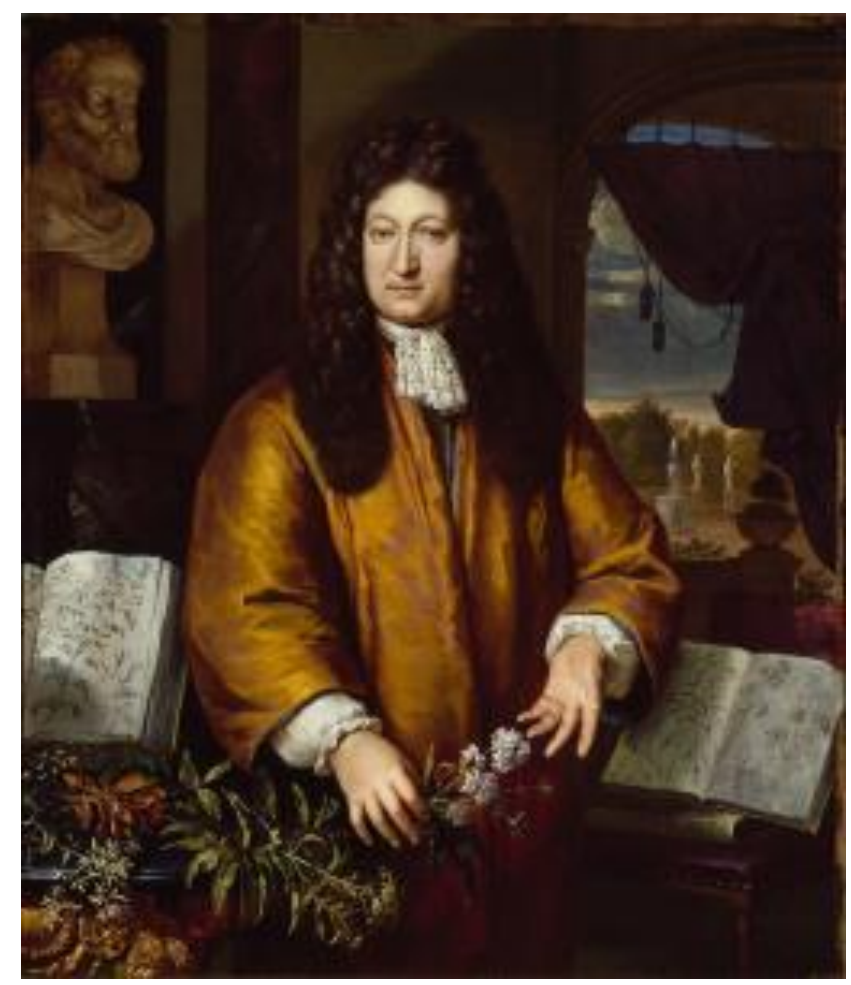

Fig. 12. Commissioned portrait of Jan Commelin by artist Gerard Hoet (Courtesy: Amsterdam Museum)

\footnotetext{
${ }^{57}$ Claudia Swan, 'Collecting Naturalia in the Shadows of Early Modern Dutch Trade' in Londa Schiebinger and Claudia Swan (eds.), Colonial Botany: Science, Commerce and Politics in the Early Modern World (Philadelphia: University of Pennsylvania Press, 2005), p. 236.

58 Jan Commelin by Gerard Hoet, Inventory Nr. SA 41466, Amsterdam Museum. Accessed online http://am.adlibhosting.com/amonline/advanced/Details/collect/39423 on 1 July 2020.

59 Amsterdam museum identifies the bust depicted in the portrait as Pliny but see a correct entry of the portrait in Menno Jonker in Karina H. Corrigan, Jan van Campen and Femke Diercks and Janet. C Blyberg (eds.), Asia in Amsterdam: The Culture of Luxury in the Golden Age (London and New Haven: Yale University Press, 2015), pp. 213-214.
} 


\section{Image as Capital: Exotica as the Marketing Tool}

The commercialization of botanic gardens occurred through the developing relationship between science and art, which in botany took place in the form of books and prints. ${ }^{60}$ Alongside the development of gardens, botanical illustrations also developed in detail and style. As discussed at length in Chapter Two, naturalists relied on local peoples to learn and collect information to craft plants, here, the medicinal plants, containing elements that are different in different worlds. Images in botanical works ease the appropriation of local knowledge-systems for marketing the collected information in the form of exotic print and pictures to investors for their commercial use.

Benjamin Schmidt argues that 'the exotic' was a Dutch invention of the seventeenth century, and the visual manifestation of it was broad and manifested across national boundaries in Europe. ${ }^{61}$ The Dutch invention of 'the exotic' stemmed from capitalist-imperialist roots, and Schmidt argues that the appeal of Dutch publishers' innovations across Europe was concomitant with declining Dutch imperial power but increasing European domination over the rest of the globe. ${ }^{62}$ Publishers established a format of printed description, which had far-reaching appeal. This appeal according to Schmidt, was largely based on the distinctive look of their books, 'their typographic construction, and their high "credit" - a term that applied both to the names on the title pages, printer no less than author, as well as to the materials presented within'. ${ }^{63}$ Dutch publishers established new ways of replicating and engaging with non-European places, peoples, and artefacts. They developed a new process of reproducing the world. The appeal of 'the exotic' such as people and plants were kept intact in the stages of production, marketing and selling 'truth' and consumption. The credit of the publisher and the author was also important for the market value of illustrations. The book markets demanded pictures, as they augmented claims to veracity made by the publishers to reinforce the production of knowledge. Social status of authors and publishing houses also played a crucial role in determining what knowledge would be circulated.

After working for several years as the editor of the Hortus Malabaricus, Jan Commelin published Hortus Medicus Amstelodamensis (The Medical Garden of Amsterdam), an illustrated account of the plants in the Amsterdam garden (in Latin and Dutch) in 1697. He was assisted in

\footnotetext{
${ }^{60}$ Alessandro Tosi, 'Botanical Illustration and the idea of the Garden in the Sixteenth Century between Imitation and Imagination' in Hubertus Fischer, Volker R. Remmert and Joachim Wolschke-Bulmahn (eds.), Gardens, Knowledge and the Science in the Early Modern Period (Switzerland: Birkhauser, 2016), p.199.

${ }^{61}$ Benjamin Schmidt, Inventing Exoticism: Geography, Globalism, and Europe's Early Modern World (Philadelphia: University of Pennsylvania, 2015).

${ }^{62}$ Schmidt, Inventing Exoticism, p.31. In Schmidt' work, he discusses how Dutch publishers like Jacob van Meurs and Pieter van der Aa, 'endeavored to make a new mode of describing the world and in process forged a new genre of geography. (see, p. 31).

${ }_{63}$ Ibid.
} 
this enterprise by two men: Frederik Ruysch, physician and Professor of Botany at the Hortus Medicus from 1685, and Franz Kiggelaer, apothecary and curator of the garden of the Secretary of States-General. The work was intended to display the botanical wealth of the new garden. The first volume dealt with plants of the East and West Indies. For example, this volume included Narcissus of Ambon, the bulb which was sent to Amsterdam from Ambon by Georg Rumphius, the famous VOC naturalist and author of Herbarium Ambonese. There are many interconnections between this project and the Hortus Malabaricus. The Hortus Malabaricus is referred to almost ten times in the first volume of Hortus Medicus Amstelodamensis. Some of the plants that are referred to from the Hortus Malabaricus are: Cara-nosi (Vitex trifolia L.), Conna (Caasia fistula L.), Ela-calli (Euphorbia nivulia), Pandi-pavel (Momordica charantia L.)(see figs. 14 and 15). ${ }^{64}$ However, while describing these plants, Commelin had not indicated that they had arrived from Malabar, but used references to describe similar plants that had arrived in the garden. Thus, natural history of Malabar plants was mobilised for personal patronage and other purposes, thousands of miles away from where the knowledge had been collected. Knowledge of Malabar plants, from the Hortus Malabaricus, became boundary objects, recontextualised and repurposed for other ends. The plasticity of objects like plant illustrations made the recontextualization possible by 'deleting local uncertainties' and complexities in the process of collecting. ${ }^{65}$

Commelin's work was published in two volumes between 1697 and 1701, with original illustrations by Dutch artists, Jan and Maria Monickx. The engravings were important in a work such as this, as they could double a book's value, even in the case of moderately illustrated books. ${ }^{66}$ Further, a separate catalogue of watercolour paintings of rare plants from the collection of the garden was published under the title, 'Monickx Atlas' after the chief artist of the paintings, Jan Monickx (see fig. 13). ${ }^{67}$ The catalogue consisted of plants from South Africa (229 species), Asia (41 species) and America $\left(97\right.$ species).$^{68}$ How to see, how to engrave, and how to represent were decided by the publishing houses which created a chaos between the compilations of text and images of exoticism. In attempts to assemble the diverse plants of the tropical world in word and image, publishing houses met with "onvolmaakte Chaos" (which Rumphius called an unruly presentation of global things). ${ }^{69}$ To make sense of such diversity of plants and their related knowledge, medicinal and botanical, European publishers used visual techniques to represent

\footnotetext{
${ }^{64}$ The online plant collections of the Amsterdam Botanical Garden use these Latin names.

${ }^{65}$ Star and Griesemer, 'Institutional Ecology', p.411.

${ }^{66}$ Margócsy, Commercial Visions, p.18.

${ }^{67}$ Jan Commelin, Hortus Medicus Amstelodamensis (Amsterdam: P and J Blaeu, 1697), p. 109.

${ }^{68}$ Kevin Frediani, 'De Hortus Botanicus Amsterdam: Developing Themes in an Established Collection', The Journal of Botanic Garden Horticulture, Vol. 7, 2009, p. 125.

${ }^{99}$ Benjamin Schmidt, Inventing Exoticism, p.276.
} 
them. The descriptions often could not fully describe the local varieties, so the visual detailing was necessary. As discussed in the last chapter, Alix Cooper's argument of how Europe invented the idea of indigenous is significant here. ${ }^{70}$ Diverse local varieties were clubbed together to form the uniform indigenous. Consequently, local varieties in plants were overlooked.

A departure can be seen here in how plants were presented to the public. The focus moved away from a plant's medicinal properties to its appearance. Through the publication of Hortus Medicus Amstelodamensis and an accompanying watercolour catalogue of plants, Commelin tried to standardise the diverse plants that had arrived in the Republic. This would also stabilise his authority in plants and place Amsterdam in the centre of the botanical hegemony of the aspiring Dutch state in this period.
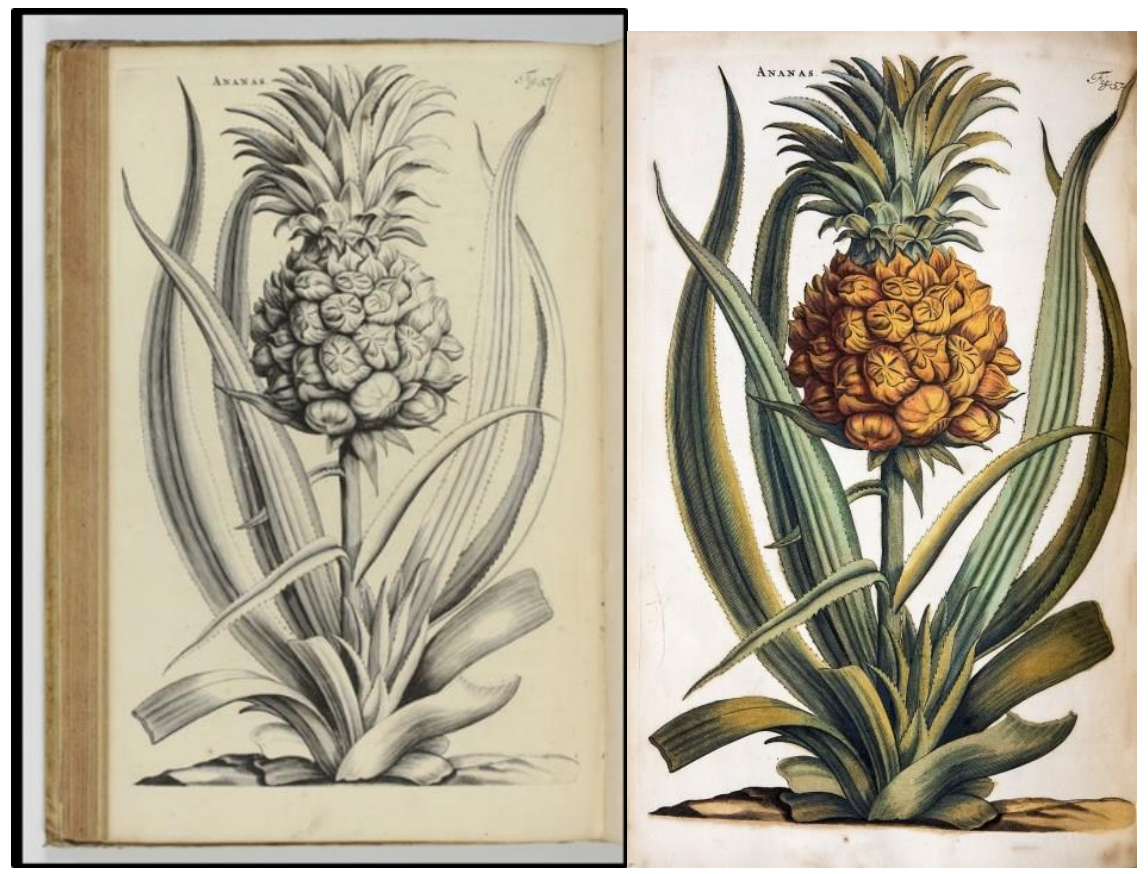

Fig. 13. Images of a pineapple illustrated in the Monickx Atlas (right) and the original drawings used in Commelin's Hortus Medicus Amstelodamensis (left). (Courtesy: Images reproduced from Hortus Medicus Amstelodamensis)

\footnotetext{
${ }^{70}$ Alix Cooper, Inventing the Indigenous: Local Knowledge and Natural History in Early Modern Europe (Cambridge: Cambridge University Press, 2007).
} 

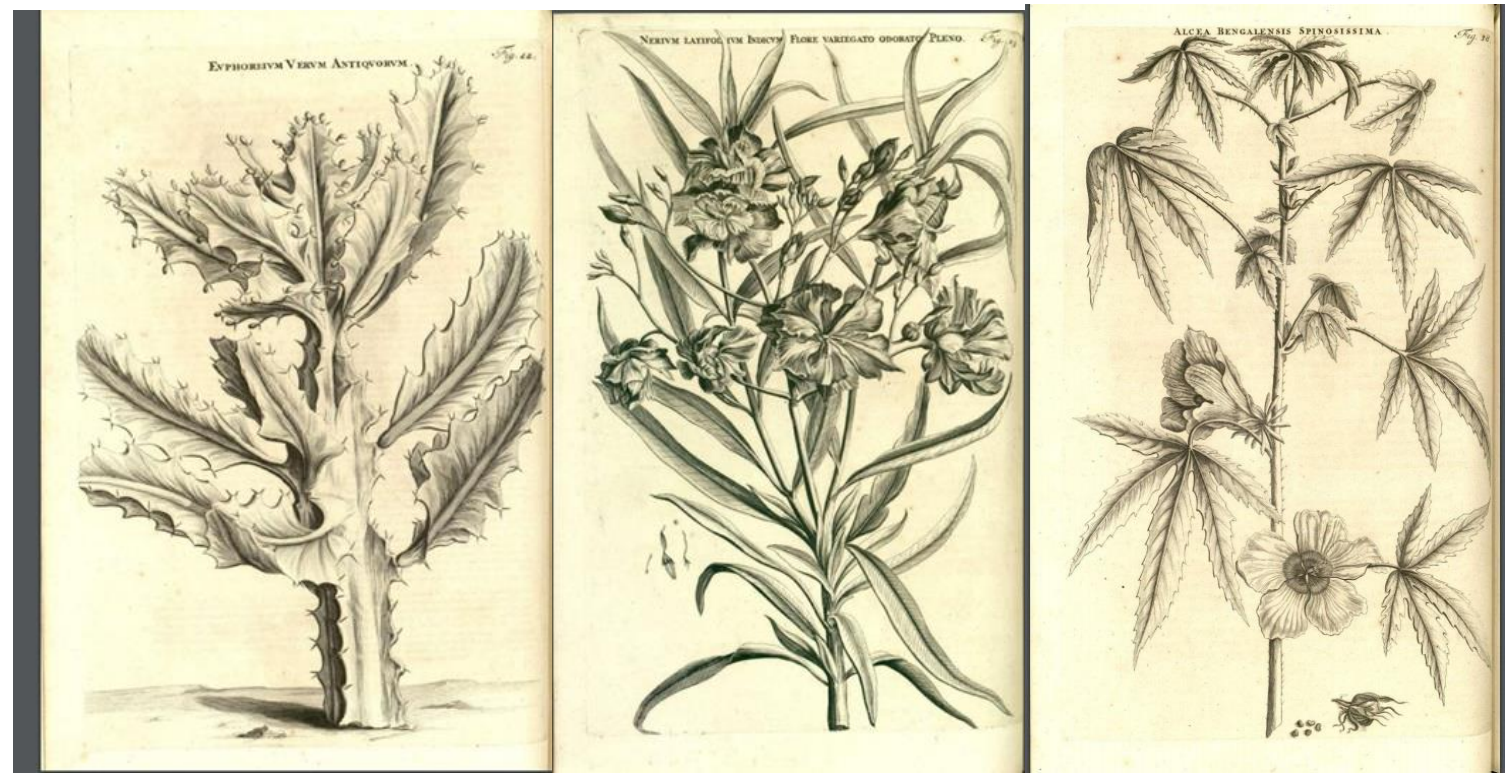

Fig. 14. Images of some plants referred to by Commelin from Hortus Malabaricus (Courtesy: Images reproduced from Hortus Medicus Amstelodamensis) 

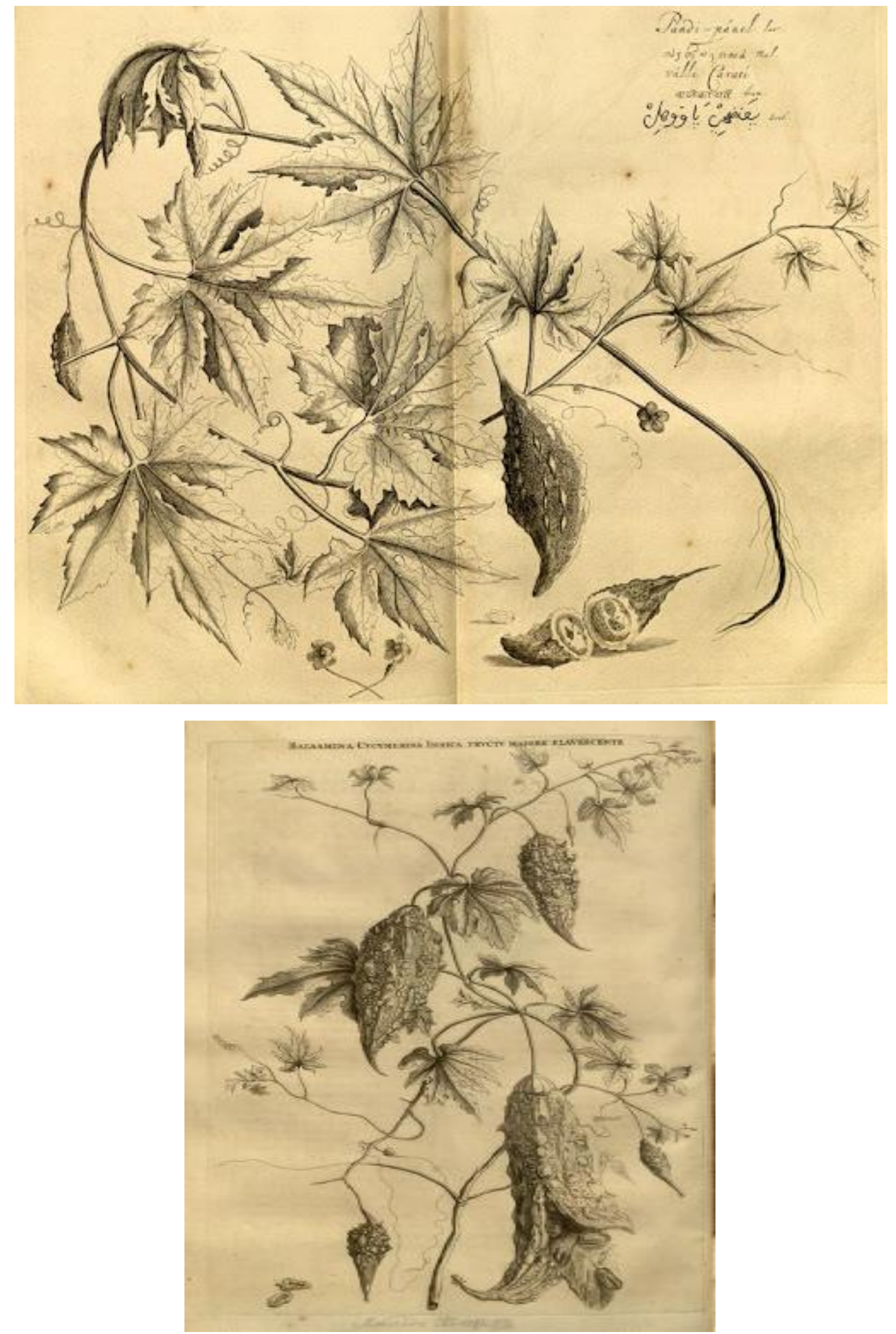

Fig. 15. Images of pandi-pavel from the Hortus Malabaricus (left) and Hortus Medicus Amstelodamenis (right) (Courtesy: Images reproduced from the Hortus Malabaricus and Hortus Medicus Amstelodamensis) 




Fig. 16. Title page of the Hortus Malabaricus Fig. 17. Title cover of Commelin's Hortus Medicus Amstelodamensis (Courtesy: Images reproduced from the Horus Malabaricus and Hortus Medicus Amstelodamensis)

Commelin's work, Hortus Medicus Amstelodamensis, was not only inspired by the botanical drawings in the Hortus Malabaricus, but the title page also owed much to this work. The print form of the first volume of the Hortus Malabaricus included copperplate engravings and a frontispiece that portrayed a tropical garden and a summerhouse set in Europe (see fig. 16). The images of natives kneeling at the feet of the goddess of botany indeed represents the moral supremacy of the European representation of colonial relations. The non-European body often served to define the exotic world which served as a key symbol to signify the exotic subject matter dealt in these books. Here, the local peoples are shown with baskets of plants and fruits in the Amsterdam city garden (identified with coat of arms, see fig. 17) that represented the sumptuous botanical wealth enclosed within its walls. The imagery also reflected the botanical hegemony of the Dutch. The images of the plants were represented away from their cultural and social contexts. This exoticism was a form of othering, which imperial authors used to emphasise dominion, as well as domestication, over the 'other'. ${ }^{71}$ The depiction of the ruins of Graeco-Roman pillars gives the title page a classical touch. It was important since classical literature was a form of conferring legitimacy on ancient early Renaissance literature. Indeed, the Renaissance of course had been founded on the rediscovery of Europe's older Greco-Roman heritage. The summerhouse template was kept alive in

\footnotetext{
${ }^{71}$ Stephen Greenblatt, Marvelous Possessions: The Wonder of the New World (Chicago: The University of Chicago Press, 1991).
} 
Hortus Medicus Amstelodamensis to symbolize the newly emerging city garden of Amsterdam. From the university gardens of fifteenth and sixteenth centuries, the garden now symbolized the public advancement in knowledge.

When Van Reede's ambitions with the Malabar plants did not succeed, he wanted to produce another work on African plants during his term at the Cape (where he went from the Netherlands). The Jesuit, Guy Tachard, Louis XIV's savant-ambassador to Siam in the 1680s met Van Reede several times during his fifteen-day stay at the Cape of Good Hope in 1685. Tachard later wrote a report on Van Reede's progress in preparing a Hortus Africus along the lines of the Hortus Malabaricus. ${ }^{72}$ Though Van Reede did not publish a work named Hortus Africus, Commelin published information on Cape flora in Jan Commelin's Cape Flora: drawings and descriptions of the plants that the Hon. Simon van der Stel, Governor at the Cape of Good Hope, found on his great journey, in 1685. Would this mean that Van Reede's draft on the Cape plants was used by Commelin for his work? Why was the book not published under Van Reede's name? The status and patronage Commelin and Huydecoper enjoyed in Amsterdam were, respectively, higher than Van Reede's. Both Commelin and Hyudecoper were naturalists in the newly emerging public. They were not employees of the VOC nor did have to get financial support from the Heren VII for their endeavours in Amsterdam. All they did was to use their connections to bring in plants from various VOC outposts to the republic. Van Reede was only a VOC official working in the Company outposts while Commelin and Huydecoper were prominent public figures in the Dutch society especially since their role as co-directors of the garden. Van Reede was never looked upon as a 'learned man of science' despite his efforts in compiling the Hortus Malabaricus. This could be understood from the numerous ways the work took prominence over Van Reede. Even in Commelin's work, references are often made to the work and not to Van Reede. This could also suggest that working for the trading company came at a cost for Van Reede. The VOC did not take an active interest in Van Reede's work on tropical botany. Jan Commelin had the advantage of working with Huydecoper, who was one of the Directors of the Company. The garden was also funded by the government. Though the seventeenth century was a period of declining armchair science, learned men still enjoyed power and patronage deriving from natural history endeavours, over Company employees or amateur naturalists.

Harold Cook observes that 'there was enough public interest about the plants of the Indies to support a multivolume work like the Hortus Malabaricus. ${ }^{73}$ Yet an analysis of Commelin's work reveals that in the seventeenth century his work on the plants in the Amsterdam garden received

\footnotetext{
72 Raj, Relocating Modern Science, pp.39-40.

${ }^{73}$ Cook, Matters of Exchange, p. 329.
} 
more funding and greater patronage from the Council than Van Reede's work on overseas plants. Apart from addressing and detailing the various networks of apothecaries, merchants and botanists that existed in the Dutch Republic, Cook's study does not address the intertextuality or intergroup politics of botanical works, which this chapter aims to further explore.

\section{The Hortus Malabaricus in circulation: Intertextuality in natural history works}

While Commelin acknowledged the Hortus Malabaricus in a few instances in his Hortus Amstelodamensis, other travellers and naturalists used the information and, sometimes, illustrations from the Hortus Malabaricus without acknowledgement. For instance, the English East India Company servant and Fellow of the Royal Society, John Fryer (1650-1753) borrowed illustrations and descriptions of the coconut and palm tree from the Hortus Malabaricus in his travelogue on India and Persia. In his work, he rearranged the order of illustrations from the Hortus Malabaricus (Volume 1) and added his own annotations (compare figs. 18 and 19). ${ }^{74}$ Since Fryer was working for the English East India Company and Royal Society of London, he seems to have restricted himself from mentioning the work of a Dutch officer. ${ }^{75}$



\footnotetext{
${ }^{74}$ Geoffrey Fryer, 'John Fryer and His Scientific Observations made Chiefly in India and Persia between 1672 and 1682', Notes and Records of the Royal Society of London, Vol. 33, no.2, 1979.

${ }^{75}$ John Fryer, A New Account of East-India and Persia, In Eight Letters Being Nine Years Travels Begun 1672, And Finished 1681 (London: RR, 1698), plates 21 and 22.
} 
Fig. 18. Plate showing coconut trees from the Hortus Malabaricus (Courtesy: Image reproduced from the Hortus Malabaricus and Hortus Medicus Amstelodamensis)

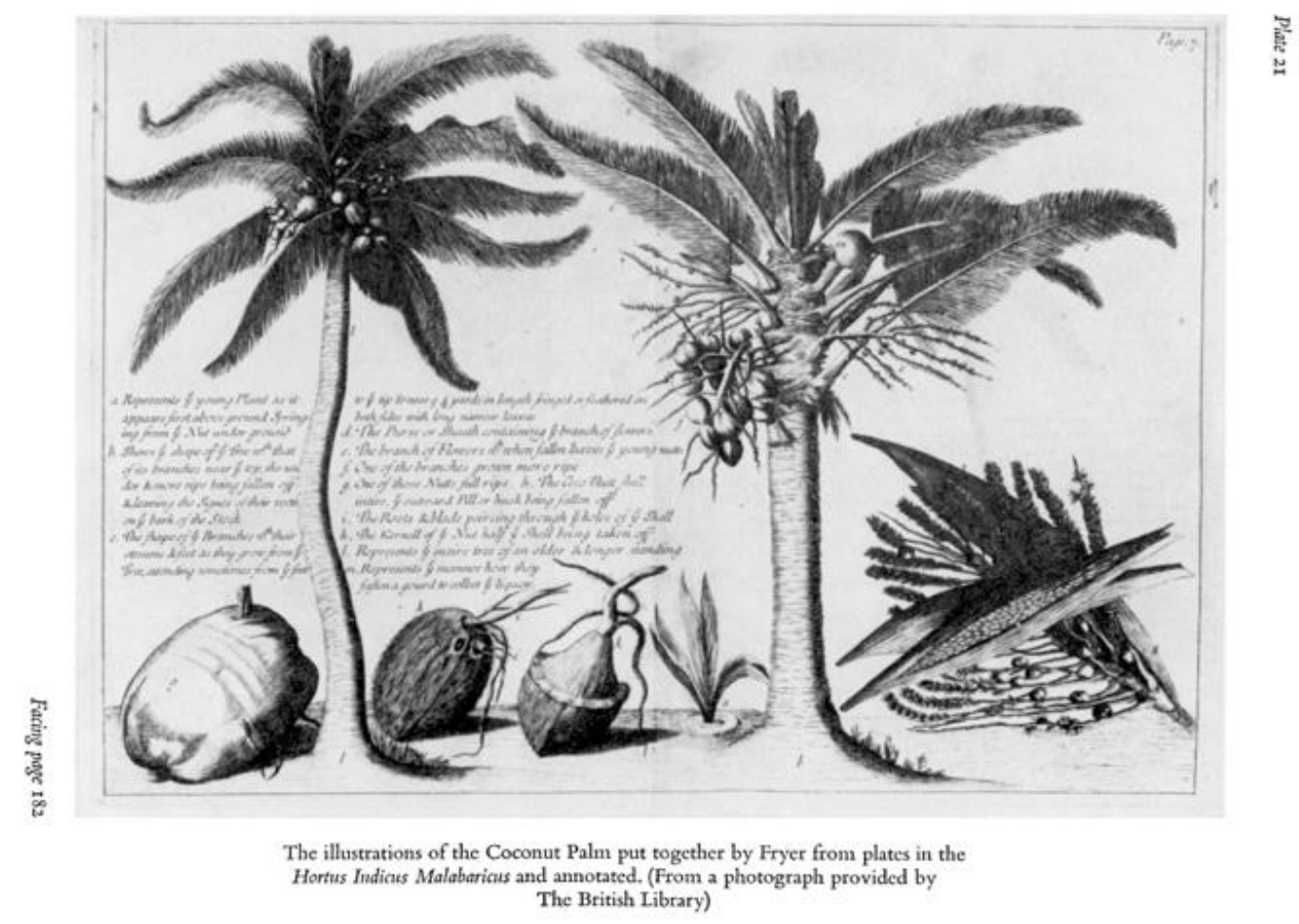

Fig 19. A plagiarised version in John Fryer's travel account (Courtesy: Image reproduced from Fryer's account)

In another instance, the well-known early modern German naturalist, Maria Sybilla Merian (1647-1717), famed for her Metamorphosis Insectorum Surinamensium (1705) (Metamorphosis of Surinamese insects), referred to the Hortus Malabaricus seventeen times in her work when describing plants seen in Surinam. ${ }^{76}$ Merian used the reference of the Hortus Malabaricus to compare similar plants she had seen in Surinam, on which insects fed. For example, she describes the fruit in one of the illustrations as 'de kappa kelengu (Ipomoea batatas L.) in the Hortus Malabaricus" (see fig. 20). The Hortus Malabaricus thus served not only as a reference book for botanical literature, but also in natural history works on the Dutch colonies in the Americas.

\footnotetext{
${ }^{76}$ Maria Sybilla Merian, Metamorphosis Insectorum Surinamensium ofte Verandering der Surinaamsche Insecten (Amsterdam: G. Valck, 1705). The work is one of the first detailed work on insects. The work describes the caterpillars, insects, frogs, snakes, spiders and ants that Maria encountered while she was in Surinam, a Dutch colony in the Americas. 77 Merian, Metamorphosis Insectorum Surinamensium, p.41.
} 


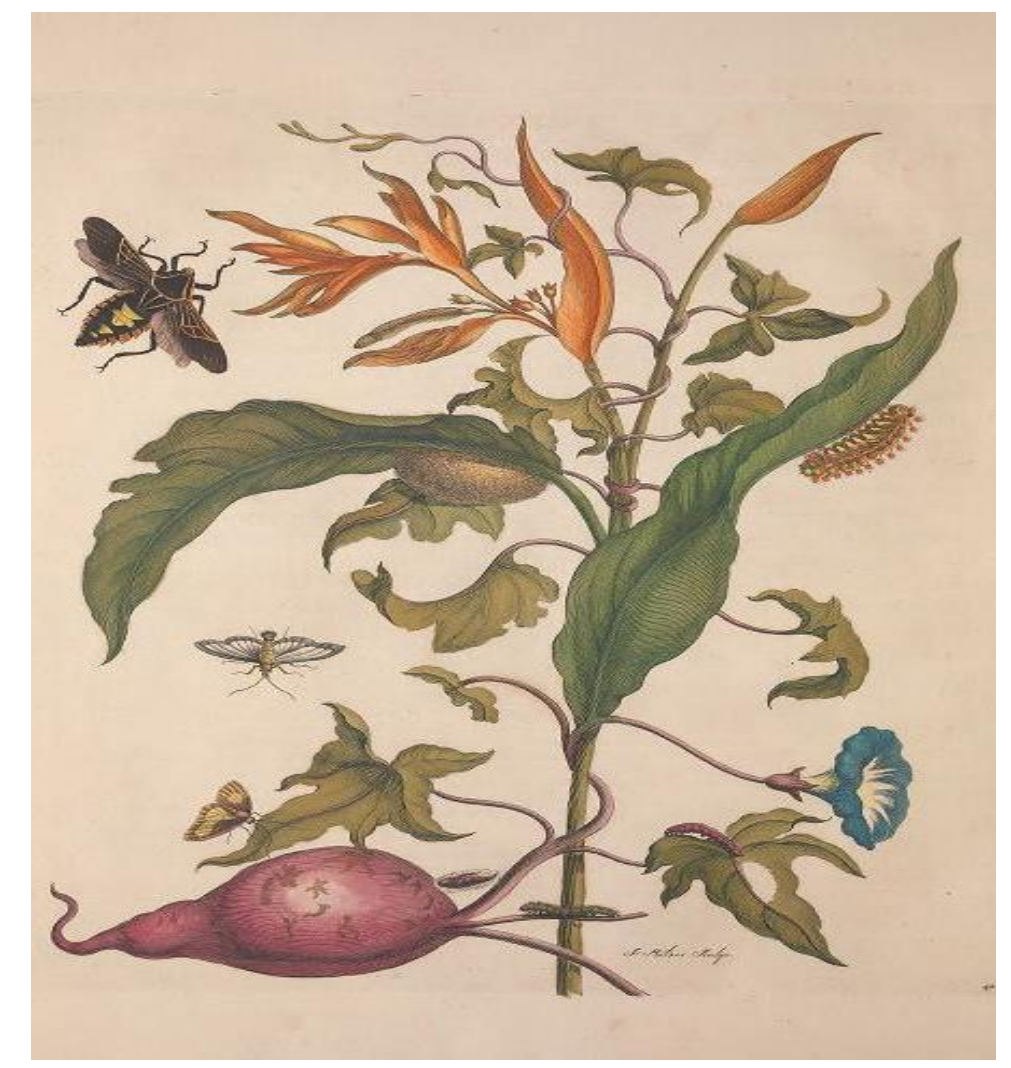

Fig. 20. An illustration of kappa kelengu from Maria Sybilla Merian's Metamorphosis (Illustration 41) (Courtesy: Image reproduced from Metamorphosis)

By the seventeenth century, images of plants from Asia were available in multiple colours and textures in different publications. Botanical works could become successful if pharmacists, wealthy burghers and aristocrats in these cities were keen to purchase such works. In order to make them universally available, naturalists developed techniques such as the literary technology of 'virtual witnessing' practised by the early Royal Society. ${ }^{78}$ Similar to the Hortus Malabaricus, most of the publications decontextualized the plants in European works. As art historian Daniela Bleichmar argues, decontextualization of seventeenth- and eighteenth-century natural history illustrations was the norm. ${ }^{79}$ The commercialisation of botanical knowledge in the Republic was a result of the numerous collaborations in the seventeenth century among artists, publishers, naturalists, botanists and medical practitioners.

\footnotetext{
${ }^{78}$ The term virtual witnessing was developed by Steven Shapin to describe the technology in describing experiments that involved the production of an image in a reader's mind that would remove the need for direct witnessing or its replication. See, Steven Shapin, 'Pump and Circumstance: Robert Boyle's Literary Technology', Social Studies of Science, Vol. 14, no. 4, 1984, pp. 491-492.

${ }^{79}$ Daniela Bleichmar, Visible Empire: Botanical Expeditions and Visual Culture in the Hispanic Enlightenment, (Chicago: The University of Chicago Press, 2002), p. 80.
} 


\section{The Hortus Malabaricus outside the Republic}

Early modern encyclopaedias of natural history were used as reference guides or 'mail-order catalogues' for naturalists who wanted to describe the exact specimens they wished to order. ${ }^{80}$ Accordingly, plant entries became short, and illustrations focused on presentations which eased classifying and identifying specimens. There was a growing tendency to replace earlier Renaissance histories of nature with taxonomical works. ${ }^{81}$ In this respect, the Hortus Malabaricus was influential in the development of botany in seventeenth- and eighteenth-century Europe, especially in influencing taxonomy and classification.

Historian Ray Desmond describes the Hortus Malabaricus as the primary source for Linnaeus's knowledge of Asian tropical flora covered in his famous work Species Plantarum (1753). Linnaeus wrote, 'I have not put my whole trust in any author, excepting the very celebrated Dillenius and the work Hortus Malabaricus by the illustrious van Reede, having very firm convictions of their accurate data'. ${ }^{82}$ Presumably, the Hortus Malabaricus was not criticised for its veracity, because the work was in a way 'European'; it was reproduced in print form by Dutchmen in Europe. The Hortus Malabaricus not only aroused interest in the Dutch Republic, but also in London. In 1683, the Philosophical Transactions of the Royal Society expressed a sense of wonder at the exotic and curative virtues of Malabar plants:

Providence seems admirably kind to those hot Countrys in providing them with such rare coolings and Cordial profitable against Feavorus, Calentures, and such like distempers as may probably arise...or corroborating and exhilarating the Bodies and Spirites of men. ${ }^{83}$

Throughout the seventeenth century, naturalists in Europe developed many different classificatory systems to identify plants. James Petiver, Apothecary and Fellow of the Royal Society of London and assistant to celebrated English botanist John Ray, referred to the Hortus Malabaricus in his correspondence for the Royal Society of London. ${ }^{84}$ In a letter to Samuel Brown, a surgeon at Fort St. George, Madras (working for the English East India Company), he penned his thoughts on the plants the former had sent to him from Madras (which he had categorised as Unanercoonda Collection of plants). Petiver identified the plants and cross-referenced them with those described

\footnotetext{
${ }^{80}$ Dániel Margócsy, Commercial Visions, p.25.

${ }^{81}$ Ibid.

82 Ray Desmond, Great Natural History Books and their Creators (London: The British Library and Oak Knoll Press, 2003), p.44.

83 “An Account of Some Books", Philosophical Transactions of the Royal Society of London, Vol. 13, 1683, p.104.

${ }^{84}$ The work was published in three volumes in 1686, 1688 and 1704. Petiver's Catalogue, a supplement containing the plates, in parts in 1715-1764.
} 
in the Hortus Malabaricus and other botanical works of the time, such as Dr Plukenet's Phytographia and John Ray's Historia Plantarum (1686). ${ }^{85}$ In the letter, he identified plants from the Hortus Malabaricus along with their medicinal properties. For example, he wrote about Carannucheel Malabaricus (Black, Agnus Castus): 'this plant in leaf and flower very much resembles the Vara Codi (Leptochilus bahupunctika) of the Hort. Malab. Vol. 9. Tab 42. P. 79. If you please send it to me (from Madras) in the seed form, I can better judge of it. ${ }^{86}$ In another instance Petiver writes about Periploca Masdraspatana as it 'somewhat resembles the Watta Kakacodi of the Hortus Malabaricus (Vol.9 Tab 15. P. 25) in its scandent quality, but our Leaves are more taper, and the Flowers come not from one Bottom and seem somewhat smaller. ${ }^{87}$ Thus, the surgeons and apothecaries in London began to use the Hortus Malabaricus as a reference for plants sent from India by their correspondents in the English settlements. Most plants in the Hortus Malabaricus were referred to by their local names in the eighteenth century. When two naturalists or collectors could agree on a botanist and their classificatory system, they could order plants from each other by describing according to their trusted encyclopaedia entry. It was essential to have an established system of identification for long-distance correspondence about specimens. Thus, having a common botanical language and what was discussed in the previous chapter as a familial bond, were crucial in ordering and trading plants.

Attempts to 'simplify' the magnitude of information in the Hortus Malabaricus were undertaken across Europe. While some naturalists attempted to catalogue the plants, others tried to create an English translation. In 1696 Caspar Commelin, nephew of Jan Commelin, published Florici Malabarici, a catalogue of the plants mentioned in the Hortus Malabaricus. While working for the Amsterdam Botanical Garden, he had catalogued the plants in the Hortus Malabaricus in English alphabetical order after identifying the Latin names with John Ray's plant classification. ${ }^{88}$ The catalogue aimed to make the classification easier for botanists as local names were hard to follow for those who had little understanding of Asian flora. For instance, a review that appeared in the Journal of Royal Society in 1701 by an anonymous reviewer wrote, 'to avoid the confounding genus (in John Ray's classification), I have chosen to call them by the Malabar name Kadali under which title there are 3 or 4 of them mentioned in Mr Ray' Hist. Plant....taken from Hortus Malab.

\footnotetext{
${ }^{85}$ John Ray, Historia plantarum: species hactenus editas aliasque insuper multas noviter inventas \& descriptas complectens (London: Printed by Henry Faithorne, 1686-1704).

86 'An Account of some Indian Plants, with their Names, Descriptions and Vertues Communicated in a Letter from Mr. James Petiver, Apothecary and Fellow of the Royal Society; to Mr. Samuel Brown, Surgeon St. Fort St. George', Philosophical Transactions of the Royal Society of London (1698), p.319.

${ }^{87}$ Ibid, p.321.

${ }^{88}$ Caspar Commelin, Flora Malabarica sive Horti Malabarici catalogus exhibens omnium eiusdem Plantarum nomina, quae è varïs, tum veteribus tum recentioribus Botanicis collegit, \& in ordinen Alphabeticum digessit (Leiden: Apud Fridericum Haaringh, 1696).
} 
Vol. 4 Tab 42. P. 87. ${ }^{89}$ While Jaspar Commelin alphabetically arranged the plants for European botanists, John Hill attempted to translate the work in English for a wider audience in Europe. In 1774 John Hill, ${ }^{90}$ an apothecary trained in medicine, wrote to the French botanist and naturalist Michel Adanson expressing his interest in translating the volumes of the Hortus Malabaricus into English. Hill wrote, 'by translating the work from Latin and classifying according to the Linnaean system, this excellent work [Hortus Malabaricus] will be even more perfect and more useful, and among the other advantages one will identify the plant by its proper name along with its primitive names'. ${ }^{91}$ In seeking funding for translating the multi-volume work, Hill requested, 'if you have the opportunity to recommend the book to your friends, or to some booksellers, you would bring me great pleasure'. ${ }^{92}$ Though there were attempts to translate the Hortus Malabaricus into English, none were successful. This was probably because of two major reasons: firstly, the local Malabar names and the rare plants from Malabar were comprehensible only to someone who was familiar with the terrain. Secondly, the project involves huge expenditures and requires patronage. It was only in 2003, centuries after the Hortus Malabaricus was published in Amsterdam, that English and Malayalam translations were published by Kerala botanist K. S. Manilal who spent 35 years on the project.

\section{Conclusion}

The circulation of information about the Indies was not merely reproduction of texts structurally intact, but a process of selection, analysis, negotiation and reproduction of knowledge collected from various actors and networks. A review of early modern botanical literature reflects the highly global character of regional networks in disseminating knowledge of tropical plants, and of the manner in which the meaning and nature of botanical work like the Hortus Malabaricus changed over time and between different locales. The European search for 'effective pharmacopoeia' was 'not to compile natural histories, but avowedly to accumulate money'. ${ }^{93}$ This chapter further adds that alongside commercial reasons, personal agenda of naturalists were also key factors for the

\footnotetext{
89 An account of part of a collection of curious plants and drugs, lately given to the Royal Society by the East India Company', Philosophical Transactions of the Royal Society of London, Vol. 22, no.264, 1701, p.592.

${ }^{90}$ John Hill born at Peterborough in 1714, was the son of a clergyman who had studied medicine at Cambridge. His medical training led to an abiding interest in botany, but without an inheritance he was dependent on patronage, his writing and the sale of proprietary medicines for an income to support his studies in this field. His proposed translations did not materialize. For more on John Hill, see, Kevin J Fraser, 'John Hill and the Royal Society in the eighteenth century', Royal Society of London, Vol. 48 no.1, 1994, pp. 43-67.

${ }^{91}$ See the full public notice in Appendix III.

92 See the full letter in Appendix III.

${ }^{93}$ Londa Schiebinger, Plants and Empire: Colonial Bioprospecting in the Atlantic World (Cambridge, Massachusetts: Harvard University Press, 2004), p.73.
} 
advancement of botanical studies. Botany became a fashionable activity, one that nonetheless needed patronage and global contacts for trading and exchanging specimens and information.

By placing native flora under the gaze of the emerging capitalist Republic and by depicting them as colonial objects of potential production, Malabar flora fed a curious book market in Europe. The information on Asian medicinal plants travelled beyond the political boundaries of the Republic. Botanical information was passed, shared and at times plagiarised when it travelled to Europe. Amateur botanists, publishers, surgeons, professors of botany and merchants, collaborated in this botanical exchange.

This chapter has analysed the transformation of local knowledge into modern botany in the backdrop of early modern European science. Knowledge was often transported and translated from afar, yet knowledge products - the consumable forms of these transfers-were further transformed and mediated by producers in Europe. ${ }^{94}$ And objects acquired different meanings when they passed from one hand to another, just as their meanings changed when moving from one place to another. ${ }^{95}$ When knowledge is transferred from one culture to the other, epistemic frictions are bound to happen. The claims to the universalism of science, in this case botanical science, which were emerging in this period, had much to do with replicating, standardising or customising of local medico- botanical practices in the Republic. The varying techniques of trust employed among the practitioners of natural history were also in turn to reduce the risk of losing credibility of their work. Often knowledge was transferred in complex and contradictory ways. What gets subdued by the beginning of the eighteenth century is the prominence of Van Reede as a naturalist. Once in Amsterdam, the work garners attention but Van Reede is seldom mentioned. The Hortus Malabaricus finds a different role in the eighteenth-century development of botany. By using local knowledge in early modern European science, the text was transformed into a scientific work that had global appeal. The work lost its local specificities in the process of standardisation. This chapter has examined how the Hortus Malabaricus had a second life in its print form. The chapter brings to light some explicit connections between political power and knowledge of nature, between the universalist claims of science and those of empire, and between social practices and modes of thought. ${ }^{96}$

\footnotetext{
${ }^{94}$ Benjamin Schmidt, 'Knowledge Products and their Transmediations: Dutch Geography and the Transformation of the World' in Susanne Friedrich, Arndt Brendecke and Stefan Ehrenpreis (eds.), Transformations of Knowledge in Dutch Expansion (Berlin and Boston: De Gruyter, 2015), p.121.

${ }^{95}$ Daniela Bleichmar, 'Seeing the World in a Room: Looking at Exotica in Early Modern Collections' in Daniela Bleichmar and Peter C. Marshall (eds.), Collecting Across Cultures (Pennsylvania: University of Pennsylvania Press, 2011), pp.15-17.

${ }_{96}$ Smith and Findlen, Merchants and Marvels, p.18.
} 
The transformation of knowledge about nature not only occurred in the intellectual domestication of indigenous knowledge in the metropole, but also in the decontextualization of the 'local'. Associated with that process of collecting scientific knowledge was the understanding of the local topography and transforming that knowledge by applying the protocols of European cartography. Also, since the establishment of the VOC in 1663, its trade initiated territorial conquests and the ecological changes in the lands of the settlements. The production of geographical and cartographical information of the settlements in Asia was therefore crucial for controlling them from the physical distance from which the Directors of the VOC ruled. Cartographical developments in the Republic projected the power of the emerging economy and commerce expanding outwards. The thesis will next examine how the VOC in Malabar engaged in producing geographical and territorial knowledge of Malabar by imposing European conceptions of space and private property over the region. The final two chapters will explore the ways in which knowledge and information on Malabar lands and geography was collected, reproduced and disseminated among networks of artists, cartographers, surveyors and Commanders in Malabar. 


\section{Chapter Four}

\section{Surveying Malabar: Visual creation of the VOC Power, 1663-1795}

In 1750, the Malabar Command consisted of the fortified town and headquarters of Fort Cochin, with four smaller forts at Cannanur, Chettuvay, Cranganur, and Quilon and many smaller posts for procuring pepper as well as ensuring that other traders did not gain access to it. These included defence works and warehouses at Alleppey, Peza, Azhikode, Chennamangalam, Pappinivattam and Ponnani. ${ }^{1}$ Two ruined forts at Castello and Pallipuram were also under Dutch control. In total, the Malabar Command, excluding Fort Cochin, had 274 canons. $^{2}$ Its forts, posts and personnel were militarily geared and well-armed for controlling the pepper trade. Of all these places, Fort Cochin was the largest and most magnificent fort on the coast. Notwithstanding all the fortified establishments, Dutch presence or economic activities in 1750 remained restricted to littoral areas only. Managing these settlements spread across the Malabar Coast was also a visual exercise. To inform the officials in Batavia and Amsterdam about the VOC territories, visual imprints like maps were necessary and inevitable.

The Dutch fort of Cochin was a relatively small town or walled urban enclave. The walls marked the boundaries of the territorial and judicial limits of the Company. The high walls were for defence and also symbolic of the status and independence of the people enclosed within them. The port area had the main entrances, warehouse and VOC offices. The rest of the fort was for residential purposes, with a school, a hospital, a church spread out within the enclave. ${ }^{3}$ Guarded by soldiers, the fort's gates-points of contact with the outside world—were narrow and fitted with wooden doors through which only a handful of people could pass at a time. ${ }^{4}$

The thesis has so far focused on the changing momentum of the spice trade in the seventeenth century, the place of Malabar within it, and the production and printing of the Hortus Malabaricus and its circulation in Europe. It has also discussed how the emerging interest in botany led to the development of European botanical gardens, aided by the arrival of plant species from Asia, Africa and the Americas (a development that meant botany was now studied in its own right,

\footnotetext{
${ }^{1}$ Anjana Singh, Fort Cochin in Kerala, 1750-1830: The Social Condition of a Dutch Community in an Indian Milieu (Leiden: Brill, 2010), p. 23.

${ }^{2}$ Ibid.

3 Ibid.

${ }^{4}$ Ibid.
} 
and not only in the service of medicine). All these processes occurred in the backdrop of the European overseas trade and its associated project of knowledge-making. This chapter will discuss another form of knowledge-making that was associated with the European imperial project. As Catia Antunes suggested, the creation of the VOC had an imperial agenda, since for the most part, the VOC worked as a sovereign organization wielding its own powers to make decisions in its trade with the native rulers in Asia. ${ }^{5}$ Territorial conquest and expansion lay at the heart of the imperial agenda and thus geography and cartography have been inseparable from the process of the European overseas project. Mapping and military operations combined to define the VOC overseas settlements.

In this and the next chapter, the thesis will examine the VOC's state making activities in Malabar in the seventeenth and eighteenth centuries that produced what Lorraine Daston termed 'bureaucratic knowledge'. ${ }^{6}$ The knowledge produced through land survey and revenue records and other official documents was essential for colonial expansion. State-making was both a visual creation through maps and a territorial accomplishment through conquest and administration. Dutch cartography reflected the growing presence of the VOC in the Malabar Coast in the eighteenth century. From having three major forts in the 1660s to holding 55 Company gardens by the 1760s, the Company's landed possessions in Malabar increased spectacularly. 'Bureaucratic knowledge' of the land and people was essential for administering this territory.

Against this backdrop, there were multiple encounters between knowledge, empire and land which formed the 'geo-body' of Malabar for the Dutch. Geo-body is a concept used by historian Winichakul Thongchai in his work, Siam Mapped, in which he argued that British mapping and military enterprise re-conceptualized the 'physical territory' of Siam in a way it differed from the earlier conceptions of space and sovereignty. ${ }^{7}$ This conception aided in holding together claims to the peoples and lands for administration. The need to dominate nature was expressed by the Dutch in Malabar through different practices, through mapping, surveying and classifying pieces of land that had different kinds of terrain, vegetation, climatic conditions and so forth. The practices of natural knowledge-making and state-making operated differently in the agenda, yet they fed each other. Natural history collection of plants was undertaken by liefhebbers (admirers of nature) directly or indirectly connected to the VOC and brought profits, status and recognition to

\footnotetext{
${ }^{5}$ Catia Antunes, 'Birthing Empire: The States General and the Chartering of the VOC and the WIC' in René Koekkoek, Anne-Isabelle Richard and Arthur Weststeijn (eds.), The Dutch Empire between Ideas and Practice, 1600-2000 (Cham: Springer International Publishing, 2019), p.19.

${ }^{6}$ Lorraine Daston, 'The History of Science and the History of Knowledge', KNOW: A Journal on the Formation of Knowledge, Vol. 1, No. 1, 2017, p. 146.

7 Thongchai Winichakul, Siam Mapped: A History of the Geo-Body of a Nation (Honolulu: University of Hawaii Press, 1994), pp. 129-139.
} 
those involved in the long-distance trade networks. The expansion of trade required calculable and quantifiable information of routes, ports, cultivable areas, settlements and peoples. Official surveys, plan of fortifications and lands also required knowledge of the nature. Thus, state-making was also a form of knowledge-making.

To get acquainted with the 'new' territories the VOC traded with, the Company used earlier Portuguese maps as models. Though there are not many records of locals assisting in the surveys, one could argue that the Company depended on the local Christian communities who spoke Portuguese for land assessment (examined in Chapter 5). Thus, activities involving local communities tied them to a common project, often a topographical map, a relief feature or a plan of the fort, that was created to fulfil the needs of European officials. Similar to how the production of the Hortus Malabaricus entailed a detailed knowledge of the regions where the plants grew, the usage of land also needed reliable local information. This chapter will try to understand how maps and surveys were not mere representation of the newly conquered areas but also the different stages of the Dutch administration in Malabar. Between 1602 and 1795, hundreds of cartographers produced topographical maps of Dutch overseas territories and charts for navigation. ${ }^{8}$ This chapter will seek to understand the maps, surveys, military plans as material creations for useful knowledge for the VOC or what Christopher Bayly called 'effective knowledge' in the context of British India. ${ }^{9}$ From visualizing the settlement, to managing it, the VOC's visual representations of Malabar catered to diverse needs of the Directors and the officials stationed in Malabar. Like in natural history, maps were also appropriating native spaces to fit the requirements of the European commercial and political interests.

Kees Zandvliet's work, Mapping for Money (1998) remains the classic work on the history of the VOC cartography of its settlements. Through a diverse set of visual sources, Zandvliet argues that maps were essentially made for commerce and fitted well into the seventeenth century commercial and visual culture of the Dutch Republic. ${ }^{10}$ Though he acknowledges that maps did not always represent the reality, this chapter argues that maps often envisioned imperial ambitions of the VOC. Taking a cue from Zandvliet's work, Elizabeth Sutton's work, Capitalism and Cartography (2015), argues that Dutch mapmaking was the product of an emerging capitalist

\footnotetext{
${ }^{8}$ Kees Zandvliet, 'Mapping the Dutch World Overseas in the seventeenth century' in David Woodward (ed.), History of Cartography (Chicago and London: The University of Chicago Press, 2007), p.1433.

9 C. A Bayly, Empire and Information: Intelligence gathering and social communication in India, 1780-1870 (Cambridge: Cambridge University Press, 1996), p.17.

${ }^{10}$ Kees Zandvliet, Mapping for Money: Maps, Plans, and Topographic Paintings and Their Role in Dutch Overseas Expansion During the 16th and 17th Centuries (Amsterdam: Batavian Lion International, 1998).
} 
nation. ${ }^{11}$ Sutton focussed on the printer and mapmaker Claes Jansz Visscher who ran a map printing business in Amsterdam.

Although this chapter draws from these works, neither study examines the VOC maps from the context of the VOC administration in a settlement or the implications of visual power in overseas settlements. This chapter examines how the making of knowledge, here, spatial and political knowledge, occurred in stages. It argues that there was no particular event of visually making Dutch Malabar, but a constantly changing negotiation between politics and power over territories. By focusing on the land-based mapmaking activities, three forms of visual representation will be examined: proposed city plans of Cochin, a military plan for the siege of Pappinivattom and the repair plans of forts and shipyard at Cochin.

\section{Cartography and imperial science, 1600-1700}

At the beginning of the sixteenth century, Portugal and Spain set up bureaucracies in Lisbon and Seville, respectively called Casa da Mina (Lisbon) and Casa de la Contratación (Seville), to control their emerging empires. These offices established the first hydrographic departments and produced the first European maps of empires, the Padreo Real and the Padron Real variously translated as template or pattern maps, standard maps, master charts and official patterns. ${ }^{12}$ By 1517, ships of the Estado da India were issued with two nautical charts before they left from Lisbon, to be handed back on their return. ${ }^{13}$ Portuguese overseas cartography of the sixteenth century produced many world atlases that became models for later European works. Many of the Portuguese mapmakers moved to Spain during the 1520s in search of better opportunities, thereby taking with them the cartographic expertise which Portugal once held. ${ }^{14}$ Portuguese's Asian cartography spread to the Netherlands from the end of the sixteenth century, as cartographers freely moved between Lisbon and Seville. During the 1580s and the 1590s, the Dutch produced manuscript charts, mostly following Spanish and Portuguese models. The advent of scientific cartography in the early modern period was in a way due to the revival of ancient texts including Ptolemy. On the one hand, the rediscovery of Ptolemaic charting, the development of Mercator's projection (1569) and the broadening empirical knowledge of non-European lands, expanded the visual horizons of minds. On the other hand improvements in printing, binding and colouring

\footnotetext{
${ }^{11}$ Elizabeth Sutton, Capitalism and Cartography in the Dutch Golden Age (London and Chicago: The University of Chicago Press, 2015).

12 David Turnbull, 'Cartography and Science in Early Modern Europe: Mapping the Construction of Knowledge Spaces’, Imago Mundi, Vol. 48, 1996, p.7.

${ }^{13}$ David Buissert, Mapmakers' Quest: Depicting New Worlds in Renaissance Europe (Oxford: Oxford University Press, 2003), p.77.

14 Ibid, pp.81-82.
} 
techniques contributed to the progress of the craft of the cartographer during the sixteenth and seventeenth centuries. ${ }^{15}$ Early modern cartographers directed their cartographic discourse to express a culturally specific geography, Weltanschaunng (conception of the world from a specific standpoint). ${ }^{16}$ Cartography and visual representation was a form of knowledge-making that involved the expertise of artists, engravers, surveyors, cartographers and military engineers.

As in the case of natural history and botany, art and science were enmeshed in the field of cartography. From recording naval battles, to the victorious tales of the VOC expansion, hundreds of images of Dutch naval victories were printed in Amsterdam. Apart from the obvious reasons to supply maps to ship captains, the VOC Directors in Amsterdam also required maps to give them a sense of being able to manage their possessions from a distance. ${ }^{17}$ Maps often aided in conquering the tyranny of distance, at least visually. The delays caused by the year-long voyages between European powers and their settlements delayed correspondence. While we have numerous works on the way cartography was used in the seventeenth and eighteenth centuries South Asia by the British, scarce research has gone into the ways the science of cartography supported early European imperial agendas. ${ }^{18}$ Matthew Edney argues that the British made general maps of South Asia by combining surveys based on local knowledge and techniques within a framework of latitude and longitude- a motley assemblage just like Portugal's Padron Real. ${ }^{19}$ Surveys were necessary for the creation of maps and plans for the VOC as well. Material representations using the new science of cartography and the visual projection of power went hand-in-hand with the Dutch project in Malabar. Visual aids reflected the territorial ambitions and segregation of the Dutch community in Cochin.

If Asian flora captured the early modern natural history works published in the seventeenth century, military endeavours and mapmaking realized the domination over territories in Asia. To ensure the control over trading routes and production centres, the VOC had to station its agents in major trading ports, possess military resources to defend settlements and observe the actions of

\footnotetext{
15 Benjamin Schmidt, 'Mapping an Empire: Cartographic and Colonial Rivalry in Seventeenth-Century Dutch and English North America', The William and Mary Quarterly, Vol. 54. no. 3, 1997, p.554.

16 Schmidt, 'Mapping an Empire', p.554.

${ }^{17}$ Matthew H. Edney, Mary Sponberg Pedley and et.al (eds.), The History of Cartography, Vol. 4 (Chicago and London: The University of Chicago Press, 2020), p.1628.

${ }^{18}$ Kapil Raj, 'Networks of knowledge, or spaces of circulation? The birth of British cartography in colonial south Asia in the late eighteenth century', Global Intellectual History, Vol. 2, no.1, 2017, pp.49-66; Sujit Sivasundaram, 'Tales of the Land: British Geography and Kandyan Resistance in Sri Lanka, c. 1803-1850', Modern Asian Studies, Vol. 41, no, 5, 2007, pp.925-965. There are a few significant works on non-European cartography and imperial agenda, mainly on Mughal India and China. See, Irfan Habib, 'Cartography in Mughal India', Proceedings of the Indian History Congress, Vol. 35, 1974, pp.150-162; Joseph Needham, Science and Civilization in China, Vol. III (Cambridge: Cambridge University Press, 1995 Reprint), pp.525-532.

${ }^{19}$ David Turnbull, Masons, Tricksters and Cartographers: Comparative Studies in the Sociology of Scientific and Indigenous Knowledge (London: CRC Press LLC, 2000), p.122.
} 
rival companies, especially the Portuguese in the seventeenth century and the English in the eighteenth. The English Parliament had passed the first Navigation Act as early as 1651 which gave a further push to the Dutch to strengthen their naval supremacy. ${ }^{20}$ The advancement in navigation was necessary to control the territorial expansion of the English in Asia.

This does not mean that the maps reflected the reality of the Europeans in the settlements. The scientific paraphernalia proudly displayed by European explorers at the beginning of the expeditions 'often exacerbated the explorers' vulnerability to the natives they encountered on their travels rather than strengthening their position of dominance over them, and frequently failed to perform their designed function'. ${ }^{21}$ In the case of the VOC, plans and proposals were drawn for the infrastructural development of the settlements, mainly Cochin, but the recommendations were never realized, as the Company did not invest heavily in Malabar. Though cartography developed, in the sense of more accurate representation of settlement, cartography was primarily a form of political discourse concerned with the acquisition of territory and maintenance of power. ${ }^{22}$ This was not only true in Malabar but in the East Indies in general. Over time, maps standardized the geographical knowledge and prescribed a set of tools to create the Company space. A visual association between landscape and sovereignty characterised Dutch colonial rule in the Indies. In her study of Dutch mapping and visual interpretation in Indonesia in the nineteenth century, Susie Protschky argues that images of conquered landscapes in the Indies bolstered moral claims to territory. ${ }^{23}$

\section{Dutch cartography in the seventeenth century}

Dutch cartography flourished in the seventeenth century in direct response to overseas expansion and newfound wealth. When the smaller trading companies of the Republic merged to form the VOC in 1602, Amsterdam became the centre for producing, printing and selling maps and charts, drawing mapmakers and engravers from other parts of Europe (earlier the centre was Edam). Often the maps produced were by artists who had never travelled outside the Republic and thus relied heavily on the local servants of the Company for the plans, drafts and other details of the VOC settlements. The rise of printing firms such as the famous Blaeu firm in Amsterdam produced some of the highest quality printed maps, globes and atlases of the time. As discussed in Chapter Three, in cities such as Amsterdam, Leiden and The Hague, publishers produced a

\footnotetext{
${ }^{20}$ Schmidt, 'Mapping an Empire', p.550

${ }^{21}$ Carole Fabricant, 'Geographical Projects in the Later Eighteenth Century: Imperial Myths and Realities' in in Maximillian E. Novak, ed., The Age of Projects (Toronto: University of Toronto Press, 2008), p.320.

22 Turnbull, 'Cartography and Science', p.6.

${ }^{23}$ Susie Protschky, Images of the tropics: Environment and visual culture in colonial Indonesia (Leiden, KITLV Press, 2011), p. 146.
} 
steady stream of travel narratives, exotic prints and accounts of overseas territories to satisfy local curiosity. ${ }^{24}$ This was both because of the interest in the global commerce and the technical advances in the Republic such as the developments in shipbuilding and nautical sciences.

In 1619, the VOC was granted a privilege from the States General stipulating that to publish any geographical information about the chartered areas of the Company, permission had to be sought from its Board of Directors (Heren XVII or the seventeen gentlemen). ${ }^{25}$ This was in response to the need to get access to knowledge of seas, coastlines, and areas then controlled by the Portuguese. This new monopoly strengthened the already close relationship between the trading company and the map production of the areas concerned. The VOC appointed Hessel Gerrritz (1617-32) as its first official mapmaker in Amsterdam. In 1618, when chart making was organized in the Republic, a map agency under the direction of the newly appointed equipagemeester (crew master) was set up for the VOC in Batavia and a chief cartographer (baaskaartenmaker) was appointed in the $1660 \mathrm{~s} .{ }^{26}$ Information gathered by the men on the settlements was used by specialized VOC personnel in Batavia to make general maps and charts. Often the initial maps produced in Batavia were updated and corrected in Amsterdam, with the assistance of professional mapmakers. Mapmakers working in Batavia were trained in the Dutch Republic usually Amsterdam, or imitated the Amsterdam mapmaking techniques, while the Amsterdam mapmakers depended on Batavia for corrected charts and new models. ${ }^{27}$ The mapmakers, surveyors and military engineers received technical training in the cities in the Netherlands before they were recruited to the VOC and WIC.

Central to the emergence of official cartography was the concept of territorial sovereignty and the idea of the state as a precisely defined and delimited geopolitical unit. ${ }^{28}$ Moreover, the institutionalization of cartography was also to prevent the leakages of navigational information through shipping networks. A small-scale navigation chart of the Indian Ocean and the adjacent coasts was developed in 1622. The model then continued to serve as the basis for the region up until the 1700s. For example, a map developed by Isaac de Graaf, the Company's mapmaker, in the years 1705-1743 was identical to that which was produced 70 years earlier. ${ }^{29}$ Joan Blaeu who

\footnotetext{
${ }^{24}$ Schmidt, 'Mapping an Empire', p. 555.

25 Zandvliet, 'Mapping the Dutch World', p.1433.

${ }^{26}$ Zandvliet, Mapping for Money, p.259.

${ }^{27}$ Kees Zandvliet, 'The Contribution of Cartography to the Creation of Dutch Colony and a Chinese State in Taiwan', Cartographica, Vol. 35, no.3-4, 1998, p.123.

${ }^{28}$ Richard L. Kagan and Benjamin Schmidt, 'Maps and the Early Modern State: Official Cartography' in David Woodward (ed.), Cartography in the European Renaissance, Vol. 3, Part I (Chicago and London: The University of Chicago Press, 2007), pp.661-679.

${ }^{29}$ See the maps developed by Gerritsz and de Graaf in Jos Gommans, Jeroen Bos and Gijs Kruijtzer (eds.), Grote Atlas van de Verenigde Oost-Indische Compagnie: India, Persia and Arabian Peninsula (The Hague: National Archives, 2014), pp. 8487.
} 
succeeded Gerritz as the VOC's cartographer produced some of the prized atlases of the VOC settlements like the Atlas Maior (11 vols.), printed in Amsterdam between 1662 and 1672. ${ }^{30}$ Blaeu's most important partner in cartography was Joannes Vingboons, a name associated with a series of about two hundred hand-drawn prototype maps, charts, views and plans, some of them were bound together in atlases called Vingboons-Atlas. ${ }^{31}$ Zandvliet describes Vingboons's works as hybrid in character: they were made to serve the VOC requirements as well as those of the Amsterdam market. ${ }^{32}$ An example was the painting (see fig. 22), depicting the victory of the VOC over the Portuguese in Cannanore (or Cananor in Dutch records), a northern settlement in Malabar where the Portuguese had built a fort as early as 1507. It was the capital of the Ali Rajas, who welcomed the first Dutch fleet that arrived on the Malabar Coast in 1604. The settlement had a strong fort built by the Portuguese, which protected the surrounding pepper-producing regions. In the painting, the narrative of the VOC victory, whose fleet arrives in a carefully crafted landscape that looks like the view of a European city with a church (a familiar landmark) with the VOC fleet proudly waving the flags. ${ }^{33}$ Until the middle of the seventeenth century, Company mapmakers Joan Blaeu and Joannes Vingboons produced images for both functional and decorative purposes. Some of the collections from Vingboons also adorned the offices of the VOC Directors in Amsterdam as they depicted what the VOC wished to see: their own global economic primacy.

\footnotetext{
${ }^{30}$ Buissert, Mapmakers' Quest, p.101.

${ }^{31}$ Ibid, p. 1441.

32 Ibid, pp. $1441-2$

${ }^{33}$ NL-HaNA, Kaarten Leupe Suppl., 4. VELH, inv.nr. 619.41. There also exist two identical earlier drafts of which one doesn't have the Dutch fleet. The Dutch fleet must have been added at a later stage after the fort was captured from the Portuguese in 1662. There also exists a Portuguese map of Cannanore from the map book of Joao Teixeira Albernaz dated 1640. Vingboons-atlas is a collection of maps and drawings made by Johannes Vingboons in his workshop in Amsterdam. It was purchased in 1869 as an atlas by the National Archives, The Hague.
} 




Fig. 21. Bird's eye view of Cannanore (1665) (Courtesy: National Archives, The Hague)

The VOC mapmakers were also independent publishers. Their productions had to cater to the needs of the Republic: both commercial and artistic. Svetlana Alpers calls the Dutch mapmakers or publishers 'world describers' and their maps and atlases as the 'world described'. ${ }^{34}$ Alpers argued that Dutch artists were inclined towards accurately representing the details of ethnography and knowledge of the world, qualities facilitated by the technical advances in the Republic, such as optical instruments. ${ }^{35}$ The basic notion of this 'impulse', she noted, was the idea that pictures were able to assert knowledge and belief. ${ }^{36}$ As discussed in the previous chapter on natural history illustrations, art played a major role in knowledge-making. In the case of maps, they made unfamiliar landscapes, familiar to Europeans. ${ }^{37}$ It is interesting to note here that the VOC could not ultimately monopolize the information of the mapmakers and printmakers, unlike other powers. Since the official VOC cartographers such as Blaeu and later Isaac de Graaf in (17051743) were also independent practitioners, they could easily trade the knowledge for their own

\footnotetext{
${ }^{34}$ Svetlana Alpers, The Art of Describing: Dutch Art in the Seventeenth Century (Chicago: The University of Chicago Press, 1983), p.122.

35 Ibid, p. 23

36 Ibid, p.119.

37 See Marion Minson, Encounter with Eden - New Zealand 1770 - 1870: paintings \& drawings from the Rex Nan Kivell Collection, National Library of Australia (Wellington: National Library of New Zealand, 1990), p15.
} 
profits. This is a contradiction to the early company policy of secrecy and preventing the free flow of information. The flow of information also occurred in other ways. For example, the Company depended on Portuguese maps for their Asian settlements. In Malabar, the transformation of conquered territories began with a transformation of Portuguese cityscapes.

\section{Turning Portuguese Cochin to Dutch Cochin}

Charles Jeurgens in his study of nineteenth-century Dutch colonial archives states that 'the lines between knowledge, fantasy and wishful thinking were easily blurred' in the VOC information networks. ${ }^{38}$ The maps and prints produced in the 1660s immediately after the Dutch success in Cochin were aimed at making the region 'Dutch'. The Portuguese legacy had to be erased and Dutch dominance had to be projected. In other words, to borrow Benjamin Schmidt's term, the VOC tried to 'Dutchify' the landscape of its settlements. This mainly entailed making the territory look like republic with the streets, public institutions, flags and names. For this, the Company needed information about the towns and its neighbouring environs. The initial maps and town plans of Cochin were modelled on Iberian information. In fact, the Dutch knowledge-making activities in Cochin were built upon Portuguese knowledge. To access Portuguese information, the Company might have used the local people who were now under the jurisdiction of the VOC, especially the Christian population. The Dutch also acquired Portuguese maps and plans through plunder of the forts and ships. For instance, a manuscript atlas of Ceylon (24 maps, ca. 1627) which was compiled in 1606 at the request of the Portuguese Viceroy of India, Francisco Da Gama, was acquired by the Dutch to be translated and copied as the Company atlas. ${ }^{39}$ The reliance on local people for the earlier Portuguese maps (not recorded in official archives) is also what this study aims to highlight. The VOC archives do not reveal the sources from where the cartographic information or plans of forts and settlements were prepared. But as a historian trying to find the voice of local people, I argue that the VOC officials depended on the local people to undertake surveys, create plans and maps of the forts and the coast. The reason for such an argument is because the reliance of the VOC officials on the local people for land management and leasing of gardens are evident from land records discussed in Chapter 5. Thus, their inputs were necessary to sketch a plot of land or map a region.

It was under Van Goen's military leadership that the Portuguese were driven out of Malabar settlements of Quilon, (1661), Cranganore (1662), Cannanore (1663) and Cochin (1663).

\footnotetext{
${ }^{38}$ Charles Jeurgens, 'Networks of Information: The Dutch East Indies, in Exploring the Dutch Empire', in Catia Antunes and Jos Gommans (eds.), Exploring the Dutch Empire: Agents, Networks and Institutions, 1600-2000 (London: Bloomsbury, 2015), p.99.

39 Zandvliet, Mapping for Money, p.132.
} 
Dutch historian Jos Gommans describes Rijklof van Goens as a man of radical military actions. His tenure and rivalry with Van Reede often originated from their dissimilar ideologies. Gommans argues that Van Goens's letters to the Council exuded a commitment to excel in Indies trade, but also a distrust and hatred for the outside world, especially of Muslim traders in Asia. He felt that the 'VOC should be self-reliant and self-supporting and not rely on their Asian trading partners'. ${ }^{40}$ Immediately after the victory in Malabar, Van Goens directed his forces to destroy Portuguese constructions including houses, churches, hospitals in Cochin. Gommans commented, 'Van Reede made Dutch history repeat itself in Cochin, Van Goens made Dutch geography repeat itself in Cochin'. In 1664, interim governor of Ceylon, Jacob Hustaert advised of the demolition of the Portuguese church Sao Domingo and permitted residents to use the stones for altering and improving the fortifications in Cochin. ${ }^{41}$

In the words of Sri Lankan historian Gananath Obeysekere a preponderance of boundary texts in the early modern period was a reaction to the redrawing or rearranging of boundaries by the Portuguese. ${ }^{42}$ This is evident in the Portuguese plans for the city of Cochin in 1640 and the Dutch plan of M. E. Proot in 1663, when the Fort was captured by the Company (see, figs. 22 and 23). The Dutch plan was probably modelled on the Portuguese plan but underwent significant change, a similar process to that which saw Portuguese street names removed and replaced with Dutch names. Also, the islands of Vypeen, Papen and St. Jago were clearly renamed with the fort named Oranje, in honour of the Dutch royal family. The other side of the city was still in the process of renaming, hence why possibly the building areas are blurry and not fully demarcated, unlike in fig. 22. The Dutch map has given prominence to water bodies such as canals, river and the sea as they are clearly marked on the plan-possibly to emphasise its accessibility or to make it appear similar to the homeland of The Netherlands. The aim of the second plan was to locate Cochin and nearby islands based on the surrounding water bodies. Here, the Dutch mapping impulse was inspired by the Portuguese plan. Colonial maps were often inundated by new signs that were necessary for colonial presence and exploitation. ${ }^{43}$ Hospitals, churches, and a shipping yard assumed prominence as signs of familiarity to Europeans ${ }^{44}$ However, more detailed scholarly exploration of mapping imperial zones and empire building has only been done of nineteenth century studies of empire, the most prominent being the British Empire in South Asia.

\footnotetext{
40 Gommans, 'Dutch Cosmopolitanism', p.10.

${ }^{41}$ Gommans, Bos and Kruijtzer, Grote Atlas, p.234.

${ }^{42}$ Gananath Obeysekere quoted in Sujit Sivasundaram, 'Tales of the Land', p.936.

43 Serge Gruzinski, 'Colonial Indian Maps in sixteenth century Mexico: An essay in mixed cartography', RES: Anthropology and Aesthetics, no. 13 Spring 1987, p. 50. More detailed scholarship on mapping imperial zones and empire building has been done on the nineteenth century, the most prominent being the British Empire in South Asia.

${ }^{44}$ For more on empire and geography see, Matthew H. Edney, Mapping an Empire: Geographical Construction of British India (Chicago and London: The University of Chicago Press, 1997).
} 


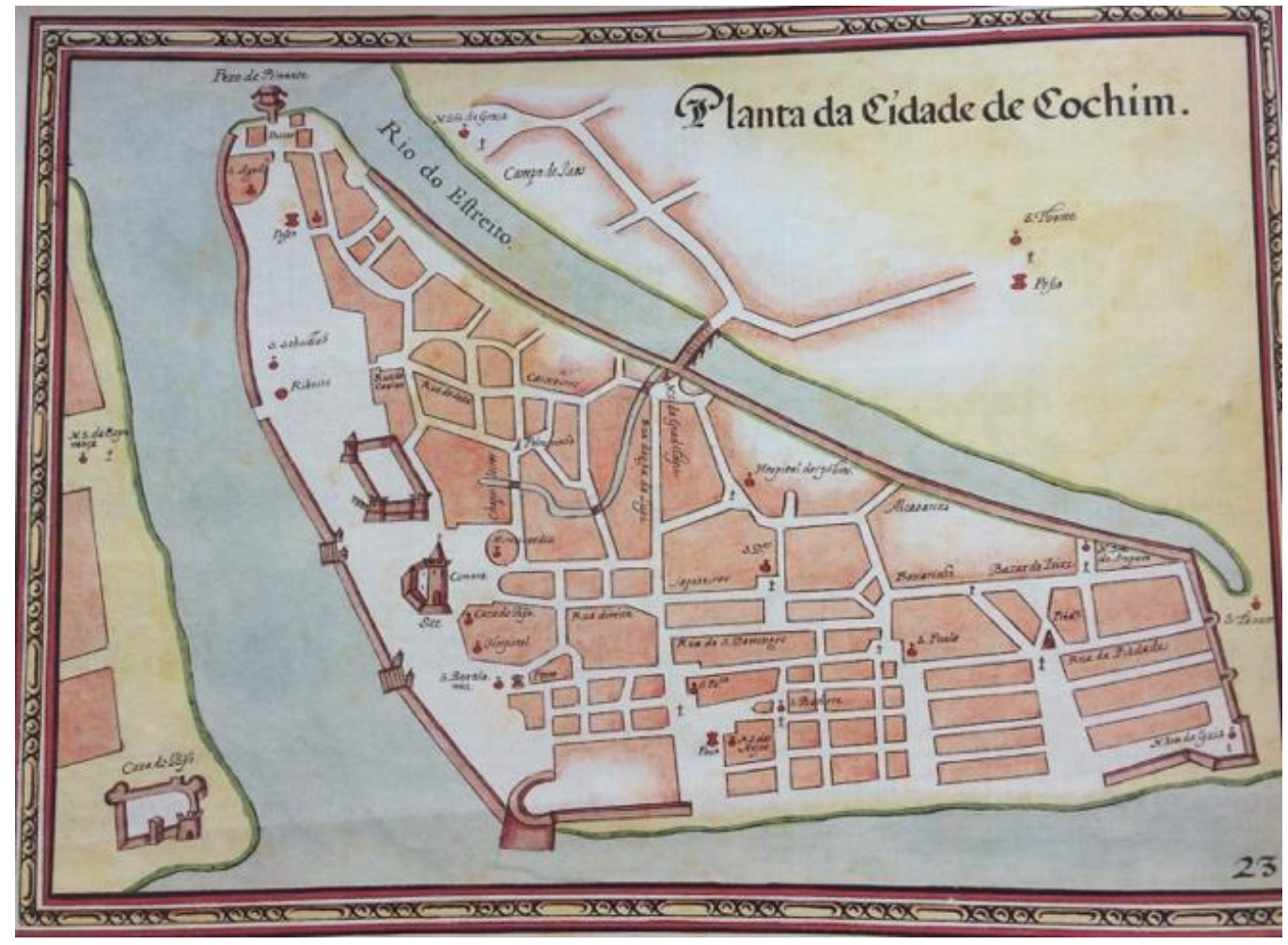

Fig. 22. Portuguese plan of the city of Cochin (1640) (Courtesy: Reproduced from De Grote Atlas, The Hague)

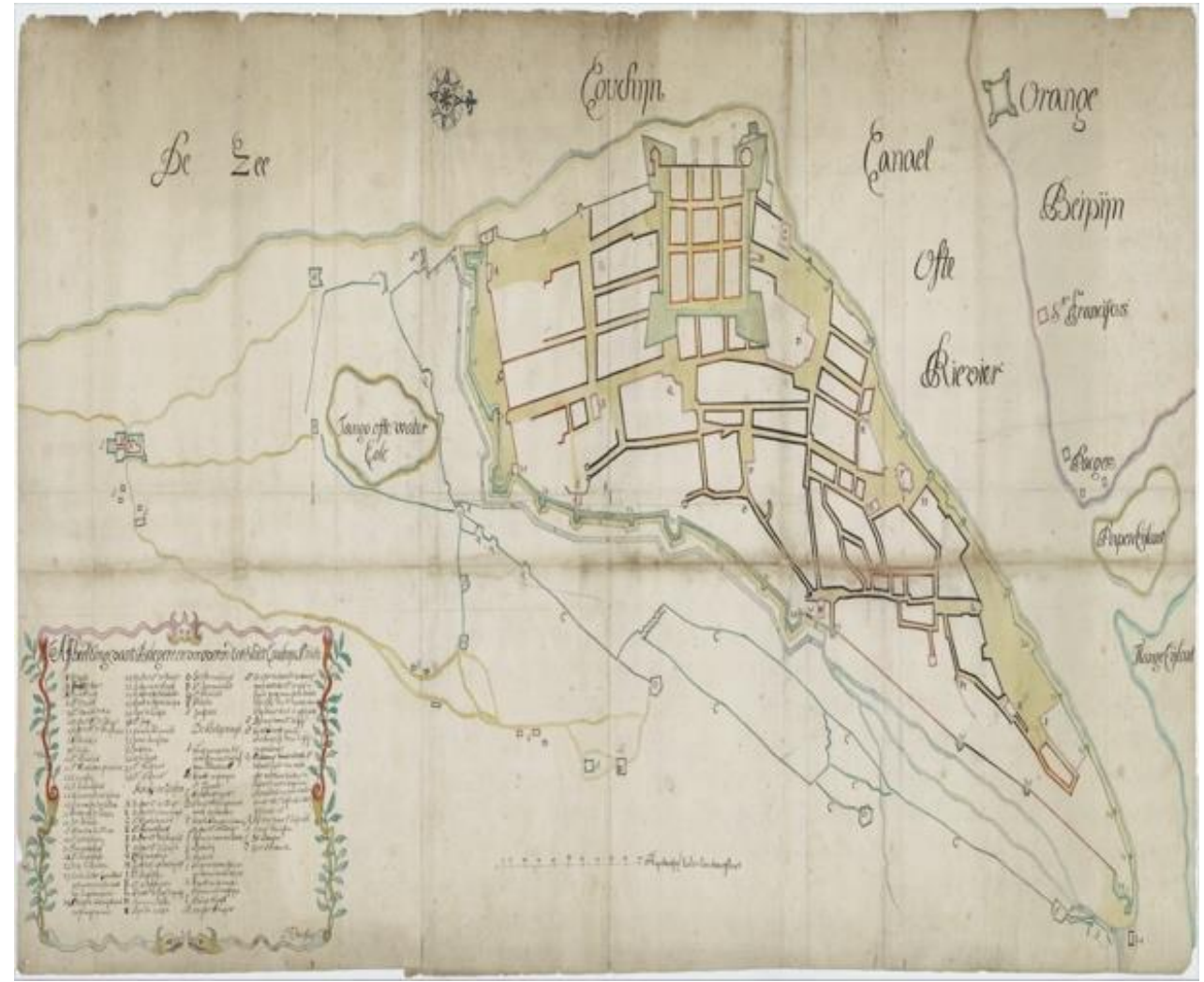

Fig. 23. Dutch plan of the city of Cochin (1663). (Courtesy: Reproduced from De Grote Atlas, The Hague) 
European cartography also depicted an important aspect of its colonial settlements - their segregation. ${ }^{45}$ Pius Malekandathil argues that the position of the Portuguese in Cochin was like other foreign trading communities in the city. European urban planning was carefully designed to isolate yet supervise the population in areas where they settled. While creating their own spaces, Europeans had to make sure they could also supervise the rest of the population. In general, there was a citadel in the settlement which provided a view over the rest of the city and its inhabitants. The population in Cochin lived in segregated groups of single religious, regional and professional communities in the sixteenth century under the Portuguese and later in the seventeenth century under the Dutch. ${ }^{46}$

The Dutch continued the Portuguese practice of setting up separate towns in their settlements, by reducing the size and structures of the already existing Portuguese towns in the seventeenth century. An English traveller wrote of Cochin: "the Dutch having this city surrendered to them in the year 1662 immediately demolished the houses and all the churches but one in order to bring it into a narrower compass and render their fortifications more regular, and they have made it almost impregnable, to which the stone of the churches they have pulled down greatly contributed." ${ }^{47}$ The town planning of the Company in Cochin was modelled after the Republic. Major street names were changed to names of the cities in the Netherlands, such as De Punt Hollant, De Punt Zeelant, De Punt Groningen and so on. ${ }^{48}$ The Dutch renamed the regions where they lived and worked, and introduced familiar features like canals, churches, and hospitals. In fact, the Dutchness of the visuals appeared through the renaming and claiming of spaces. Despite its European urban infrastructure and form, in the Dutch city of Cochin more than half of the citydwellers were non-Dutch, with a great many native people and a considerable number of Toepassen (or Portuguese casados), Jews, Konkani and Tamil Pattars. Toepass refers to mixed race people of Portuguese descent who intermarried natives and practiced Catholicism. They lived around the European factories and forts in Cochin and other Company settlementsIn the Dutch city of Cannanore, the number of Dutch settlers did not exceed more than two figures in the seventeenth century. In other words, the Dutch urban units had much a smaller number of non-native residents compared with the highly populated regions

\footnotetext{
${ }^{45}$ See for instance, Anjana Singh, Fort Cochin in Kerala, 1750-1830: The Social Condition of a Dutch Community in an Indian Milieu. (Leiden: Brill, 2010), p.74, where the author argues how the fortified walls separated Dutch officials from the local settlements.

${ }^{46}$ Gommans, 'Dutch Cosmopolitanism', p.11.

47 Zandvliet, 'Mapping the Dutch World Overseas', p.1446.

48 Many of these street names are still in use. For more see, Chapter One in Singh, Fort Cochin in Kerala.
} 
around Cochin, Cannanore and other islands. ${ }^{49}$ The science of cartography gave the Company power to produce images of Malabar in which they effectively mixed idealized and useful information. The power enjoyed by the Dutch in the knowledge-production was enjoyed by the Portuguese too; but the increasing dominance in inland Malabar gave the region a permanent Dutch imprimatur through the production and reproduction of the Dutch ideas of Malabar. So, the Dutch were not creating a new space but reimagining an old space with new symbols and new names. This was not creating 'new' knowledge, but a re-organisation of old knowledge.

\section{Re-claiming Pappinivattom}

The seventeenth century changed the needs of the Company as its territorial jurisdiction expanded. In India, the French, Dutch and British East India Companies were contending with each other for territory and trade. ${ }^{50}$ In this context, the management of territories and, more importantly, control of territories were of key importance. The emerging use of 'land' as a commodity from which revenue could be extracted ran parallel to Dutch expansion into the interiors of Malabar. Earlier, the focus of the Company was on trade, but since its active engagement with the local kingdoms in the eighteenth century, the VOC also became a custodian of lands. In the context of English East India Company, sociologist Zaher Baber argues that through surveys, the British sought to remove contingency and the unexpected with a measure of predictability. ${ }^{51}$ The same was also true for the Dutch.

For the VOC, the plans of maritime centres of trade and military posts were not enough, as the Company expanded its dominance over more territories away from the maritime centres in the eighteenth century. Quite simply, the mere production of topographical maps did not meet the demands of the management of its territories in inland Asia. Though in the Republic, the VOC concentrated on maritime mapping, the officials at Batavia and settlements required land surveys, fortification plans and other useful information. In the seventeenth century, land surveying was undertaken by military engineers, mainly for the building of fortifications and, in the case of Cochin, to reduce the size of fortifications and apply the precepts of town planning. Zandvliet argues that the surveys undertaken by local officials produced some high-quality maps of the VOC

\footnotetext{
49 Pius Malekandathil, 'Changing Perceptions of Sea and the Shaping of Urban Space in Medieval Kerala,' in K. Madavane (ed.), Histories from the Sea: Proceedings of International Conference 30-31 January 2007 (New Delhi: Jawaharlal Nehru University, 2009), pp.50-67.

50 Zaheer Baber, 'The Plants of Empire: Botanic Gardens, Colonial Power and Botanical Knowledge', Journal of Contemporary Asia, Vol. 46, no.4, 2016, p.661.

51 Ibid, p.661.
} 
settlements. ${ }^{52}$ The expanding dominance of the VOC in the Malabar Coast meant that maps and plans were required for the depiction of commercially viable lands as well as for showing strategic locations necessary to ensure territorial control. In the context of Malabar, this is best exemplified through the case study of the Company siege in Pappinivattom and its villages.

The 18 half-villages in the Province of Pappinivattom (spelled in Company maps and records differently as Paponetty, Pappinivatti, Papinette) were a regular topic of discussion among officials from the 1719. This strange term-18 half-villages — refers to a plot of territory stretching from the sea to the backwater between the northern limit of the kingdom of Cranganore and the southern limit of Pappinivattom near Chettuwa. ${ }^{53}$ These villages belonged to the Zamorin, ruler of Calicut (lying $400 \mathrm{kms}$ north of Travancore and $27 \mathrm{kms}$ north of Cochin), who was not one of the Company's rivals at the beginning. During the Company's early years in Malabar, it had even a joint agreement with the ruler against the Portuguese. It was only later when the VOC became a close ally of Cochin, and became involved in the Cochin-Calicut wars, that it made itself a clear enemy of Calicut. After 1715, relations strained when the troops of the ruler of Calicut attacked and destroyed a small Company fort in Chettuwa. In 1716 Company troops along with the forces of Ravi Varma, Cochin ruler, counter-attacked and reconquered the Chettuwa fort. ${ }^{54}$ The plan for the siege (as shown in fig. 24) ${ }^{55}$ and similar other plans were made by the men who surveyed the region on the spot. These were sketches mainly of the fort to be attacked and the routes to reach it. These plans wiped off the neighbouring environs by only showing the target of the VOC. In these drawings, the VOC conveniently rubbed off the surroundings by having signs of economic importance such as such as klapper thuijnen (coconut plantations) (see fig. 25) — the significance of coconut plantations will be detailed in the next chapter. ${ }^{56}$

The conquest of Pappinivattom was crucial as it held the 18 half-villages that had rice fields and coconut trees that generated land revenue. On 16 January 1717, after two failed attempts, the High Commissioner sent a large expeditionary force from Java under the supreme command of admiral and general Willem Backer Jacobsz. Bergman, the adjunct commander in field, defeated the local ruler's army, and later occupied smaller fortifications north of Pappinivattom, Edathurutty and Maprana. On 23 January, Chettuwa was conquered and nearby rice fields were

\footnotetext{
52 Zandvliet, Mapping for Money, p. 107.

$53 \mathrm{MvO}$ Adriaan Moens dated 1781, p. 127-129. Moens notes that such a name was given because the territory consisted of 18 pieces of ground each of which constituted a kind of village with houses and cultivable land, so each piece is called a half-village instead of a village.

54 Ibid, p. 128-9.

${ }^{55}$ NL-HaNA, Cards Leupe, 4.VEL, inv. 918.

${ }^{56}$ NL-HaNA, Cards Leupe, 4.VEL, inv. 921 Pagger is the Dutch spelling for Malay pagar that is understood as a hedge or a fence around a house, made of bamboo or shrubs. See, E. M Beekman, Fugitive Dreams: An Anthology of Dutch Colonial Literature (Amherst: University of Massachusetts Press, 1988), p. 321.
} 
confiscated. ${ }^{57}$ The ruler of Calicut ended the siege by signing a treaty with the Dutch whereby they gained sovereignty of the coastal tracts that lay between Chettuwa and Cranganore, which were repeatedly indicated in the maps from 1767 as 'Conquest Papponetty' (see Map 2). The VOC dominance was visually imprinted on the map, whereas other lands were mentioned as belonging to various kingdoms outside their purview.

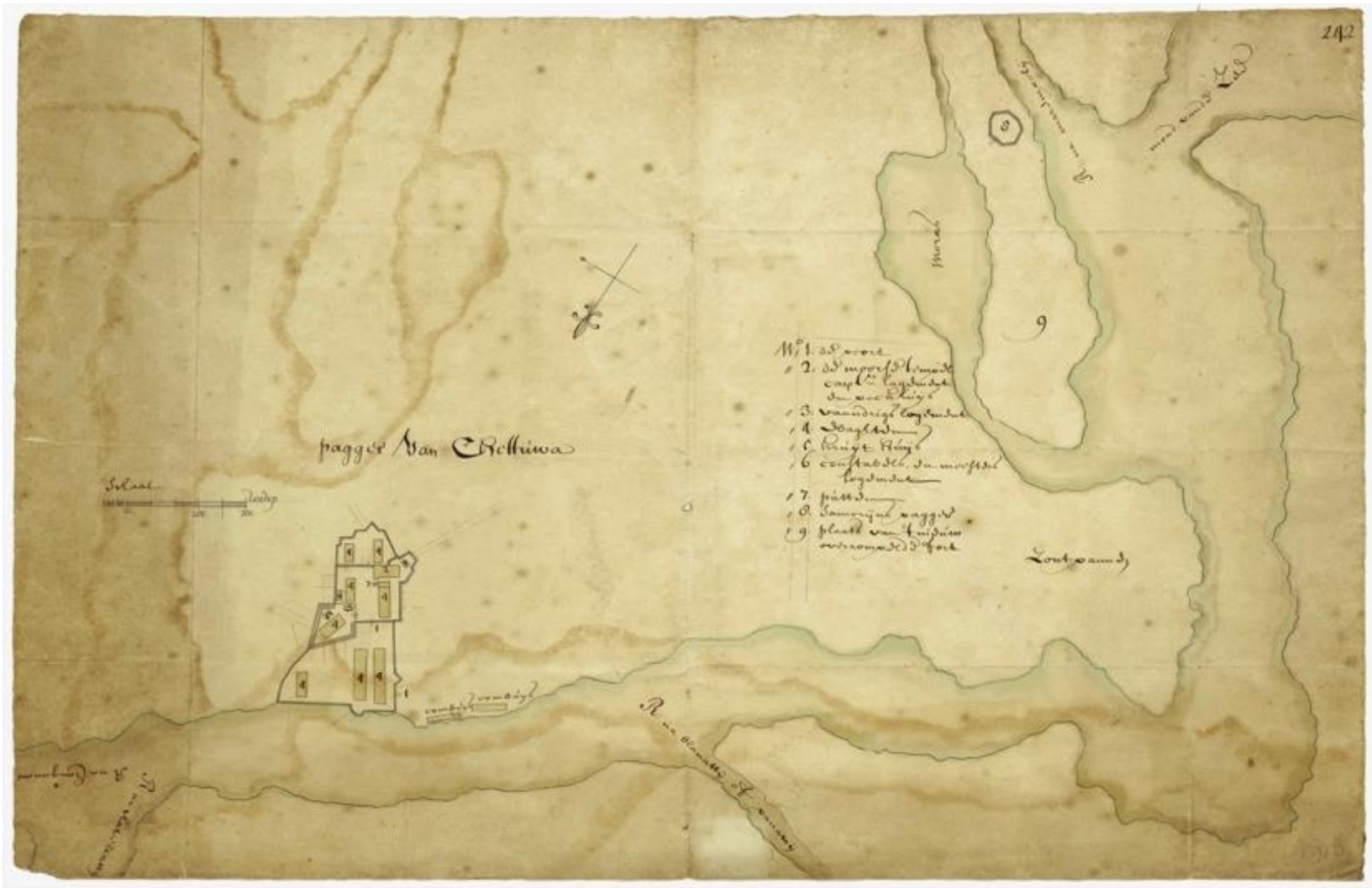

Fig. 24. Plan of Chettuwa (Courtesy: National Archives, The Hague)

57 The conquest of Paponetty, Cochin records, No.6, p. 149. TSA, Chennai. 


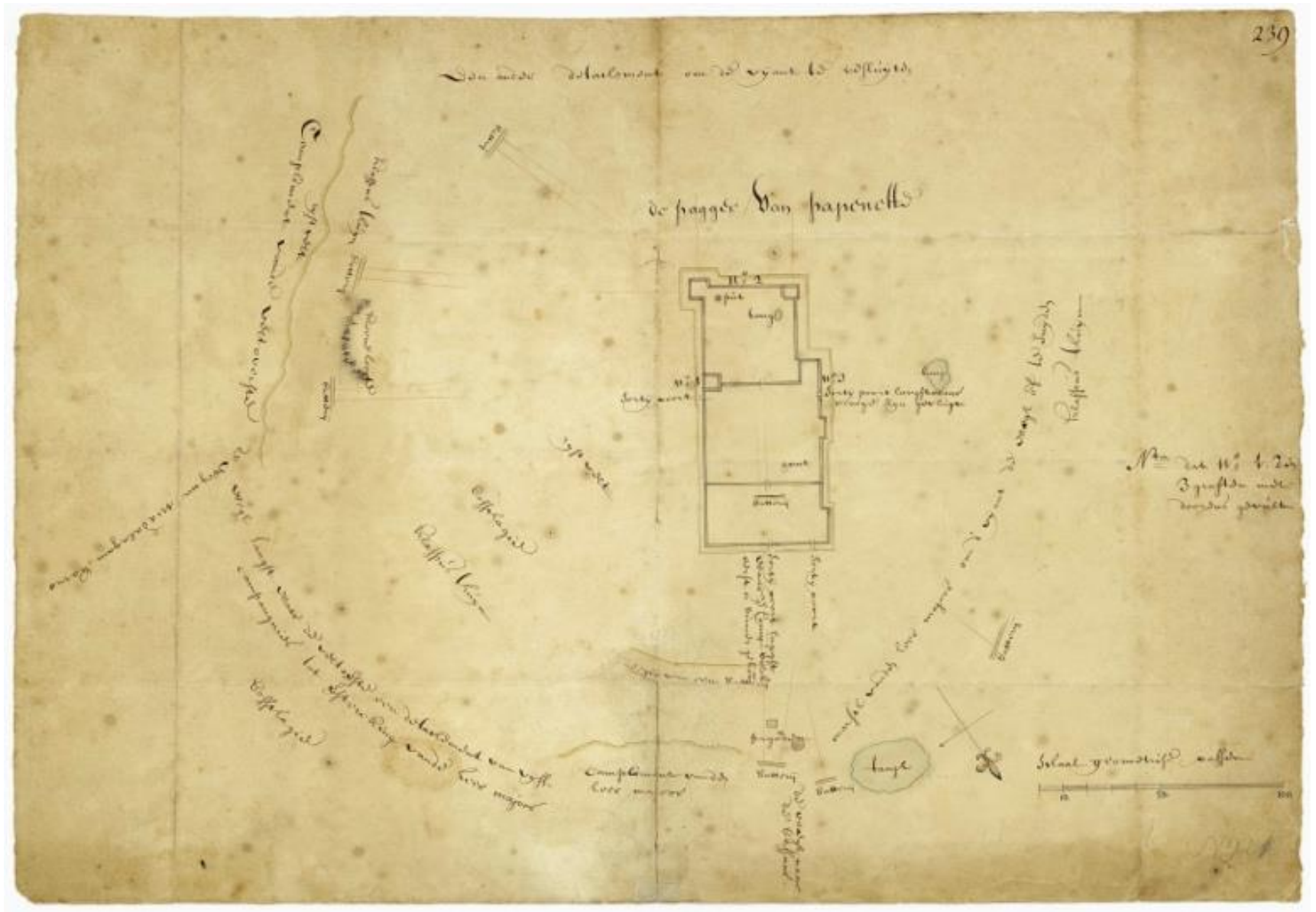

Fig. 25. Plan of the Siege of Pappinivattom (Courtesy: National Archives, The Hague).



Map 2. Malabar Coast with areas demarcated as Conquest Paponnetty of Compagnies Landen (1767)

(Courtesy: National Archives, The Hague)

The Company proclaimed legal possession of these lands in 1719, but the situation on the ground remained complicated. In 1740, the Dutch Governor Van Gollenesse gave these lands to the ruler of Cochin, as he claimed that they originally belonged to him. In 1757, the lands were reclaimed by Calicut following further disputes with the Cochin kingdom. In 1758, the ruler of 
Cochin then led an expedition to invade and reclaim the 18 half-villages as compensation for the cost of war against Calicut. The Pappinivattom villages were the most sought-after region for the income they generated from the cultivation of rice and coconuts. The local ruler gave these lands to the Company for their help against the troops of Calicut. The VOC enjoyed revenue from the region until 1769 before Commander Cornelius Breekpot wrote to Batavia confirming that the lands were returned to Cochin because the ruler insisted. ${ }^{58}$ Since further details of this saga are not documented, what can be assumed, is that the territory of Pappinivattom and its boundaries were constantly redrawn between 1717 and 1769. The land revenue from these regions attracted the VOC and these villages were repeatedly highlighted in the Company maps in bold letters as Compagnie landen. By enclosing the land with clear boundaries, the VOC was making it private, saleable, transferable and taxable rather than a public land. The VOC tried to project this region as belonging to them, although they were only the custodians of lands in the few years between 1719 and 1769. The VOC maps regularly demarcated the region with red borders; the complexities within those boundaries were never marked out. Writing in 1771, Commander Adriaan Moens expressed the confusion over the authority of the lands. Moens wrote to Batavia,

our lords and masters [in Amsterdam] had not been clearly enough informed by this Government [in Malabar] on what grounds the lands were restored to the ruler of Cochin or any further particulars of the whole question of these villages; and although they are no longer in our possession, I have thought it not unserviceable to bring together here all I knew about. ${ }^{59}$

It is possible that the Commanders of Malabar made decisions regarding these lands without informing the High Government at Batavia or the Directors in Amsterdam, or the regional politics were sometimes too difficult for the Dutch to comprehend. Early modern encounters also indicate the issues inherent in the 'contact zones ${ }^{60}$ like Malabar where the political and linguistic terrains where too rigid to navigate. The lack of linguistic and other skills needed to 'read' cultures accurately often resulted in situations where the officials became more inconclusive of their observations despite a greater understanding of geography. ${ }^{61}$

\footnotetext{
${ }^{58} \mathrm{MvO}$ Adriaan Moens dated 1781, p. 128.

${ }^{59} \mathrm{MvO}$ Adriaan Moens dated 1781, p. 128.

${ }^{60}$ See the use of the term 'contact zone' in Mary Louis Pratt, Imperial Eyes: Travel Writing and Transculturation (London and New York: Routledge, 1992), p.4

${ }^{61}$ Fabricant, 'Geographical Projects', p.321.
} 
The political climate in Malabar in the eighteenth century was defined by constant feuds between the ruling families, which resulted in the redrawing of ill-defined borders. Instead, the Company maps kept the borders static and clear and did not reflect the changing political geography in terms of land ownership. For example, in the context of Malabar, a major part of the cultivated lands belonged to the temples (devaswom lands), as had been the case since the medieval period. The Company maps reflected neither the fluid state of Malabar politics nor the nature of land ownership, a complex system with lands owned by religious institutions and minor feudal lords. The Company maps of the coast of Malabar were prepared from the perspective of the Company and reflected the way in which the VOC wanted to project itself in the region in the eighteenth century. According to R. Redmond Cross, Dutch printed maps in this period reflected and reinforced an episteme that integrated humanist ideals with the concept of national state and modern capitalism. ${ }^{62}$ Surveys and maps of the conquered territories such as Malabar helped create a well-defined geographical entity, which was otherwise considered to be an exotic, unknown and a rather complex space. It also resulted in the introduction of practices that were new to the local political kingdoms whose boundaries were never fixed in the way required by the Enlightenment science of mapping. The VOC attempted to legitimize their presence in Malabar by politically reconstructing a complicated physical space and its maps visually represented that political project.

\section{'Project plans of 1767': Failed proposals?}

These visual representations are not to be confused with the reality on the ground. Maps were sent to the Directors who could look at the visual representation of Dutch dominance overseas. Maps in that sense gave an illusion of Dutch prominence in the eighteenth century when the Dutch were actually losing control over their Malabar settlements. The presence of the English East India Company in the Malabar coast was nowhere represented in these maps or plans. The fear of maps falling in the hands of the British when they took over the Dutch possessions led many Dutch officers to destroy, hide and take the maps with them when they returned to their home country. For instance, the Dutch Governor at the Cape, Jacob Cornelis van de Graff, when he left in 1791 took away with him many maps, charts and plans produced during his term in the Cape Colony. ${ }^{63}$ In another case, to mislead rival companies, the Dutch had false maps published of the Spice

\footnotetext{
${ }^{62}$ W. Redmond Cross, 'Dutch Cartographers of the Seventeenth Century', Geographical Review, Vol. 6, no. 1, July 1918, p.66.

${ }^{63}$ Elri Liebenberg, 'Unveiling the Geography of the Cape of Good Hope: Selected VOC Maps of the Interior of South Africa' in E. Liebenberg and I.J Demhardt (eds.), History of Cartography: Lecture notes in Geoinformation and Cartography (Berlin and Heidelberg: Springer-Verlag, 2012). Cape colony fell into the hands of the British in 1795.
} 
Islands of the Moluccas, the prime centre of nutmeg, mace and clove trade. ${ }^{64}$ Thus, maps were entities often used to claim, possess, legitimize, control and contest possessions.

In Malabar, the VOC struggled to maintain its military presence and fortifications. Apart from the surveyors and mapmakers, the VOC employed military engineers who were active in the compilation of engineering drawings, building plans and topographic maps. These were professionals who played a significant role in the making of empire but were never remembered for their contributions. The movement of technical knowledge from the Republic to the settlements required technical assistance. Kapil Raj calls for an approach where voyages of discovery should be seen

as a system which includes ships, shipbuilding, repair, docking facilities, the logistics of keeping hundreds of sailors nourished and healthy in limited spaces for long periods, navigation, hydrography and surveying, along with natural history, anthropology and the other domains to which they more or less contributed. ${ }^{65}$

In his argument, expansion and success of European overseas trade was largely dependent on scientific expertise and material practices. Though Raj argues for the existence in the eighteenthcentury of 'big science', one can argue that even in the seventeenth century, navigation and surveys and logistics played an equally important role in the voyages (and hence, trade) of European companies. Even from an early period, Companies employed astronomers and hydrographers as navigators and medics for treating crews and for the identification of commercially viable plants or derived products. ${ }^{66}$ The archival records on the VOC engineers and surveyors for this period are scarce and this chapter has not attempted a history of their technical know-how. Nevertheless, by examining the existing VOC plans in Malabar, the chapter has highlighted the importance of skilled Dutch cartographers and surveyors, and demonstrated the way in which these individuals, as well as their productions, connected the Netherlands and its colonies.

What is often not recognized by historians is the development of the various academic fields in the Republic that trained military engineers, cartographers and surveyors. The pursuit field like mathematics flourished on a marked interest of the social elite in things mathematical, because

\footnotetext{
${ }^{64}$ Raj, 'Networks of Knowledge’, p.91.

${ }^{65}$ Kapil Raj, '18-century Pacific voyages of discovery, "big science", and the shaping of a European scientific and technological culture', History and Technology, an International Journal, Vol. 17, no. 2, 2000, p.82.

${ }^{66} \mathrm{Raj}$, ' $18^{\text {th }}$ century pacific voyages', pp. 83-84.
} 
of its utilitarian as well as its cultural value. ${ }^{67}$ As a result, there developed a generation or more of professionally skilled technical people who assisted the Company. As for Malabar, the expertise of these professionals was hardly recognized as most of the project plans proposed for the Company settlements until the year 1767 never materialized. This could be because the Company failed to deploy a string of cartographers, surveyors, engineers and skilled workers to work on a common project in South Asia. Two examples analysed here are a plan for the reduction of the size of Fort Cochin and the construction of a shipyard at Calvethy river. The resizing of the captured Portuguese and native forts and the strengthening of encampments and stockades meant economic pressure for the VOC. As a settlement that did not generate the profits the Company had hoped for, investments for the improvements of the infrastructure was not a priority.

Military engineer Pieter Gijsbert Noodt oversaw inspecting, surveying and mapping the defensive works in the Company establishments at the Cape and in Asia. In Malabar, Noodt inspected settlements in Cochin, Cannanore, Quilon and Chettuwa where the Company had forts in 1720. On the basis of his survey reports, it was decided that Cannanore and Quilon were expensive and weak, and proposals were made in the 1760s to demolish the Portuguese forts, reduce their size and equip them with a better walled lodge. ${ }^{68}$ There was a gap of forty years before a proposal was made based on the survey of Noodt, indicating the lack of funding for such projects. Though plans were made from time to time in the eighteenth century, they were not realized. Again in 1765, plans were made to reduce the size of Cannanore fort and project maps were made by military engineers E. Paravicini de Capelli and J. L. Guyard. Since the fort was eventually sold to Ali Rajas in 1771, these project plans were also never implemented. As Chandra Mukherji has eloquently argued in her work on the Canal du Midi, territorial projects required epistemological work and the labour of construction, meaning the need for knowledge (in terms of geography, terrain, soil types) to undertake a project and the labour to execute the plan. ${ }^{69}$ Labour often came from people who knew the land. In Malabar, the VOC could not successfully assemble the labour, finances and technical know-how at the same time. This brings to light the clear gap between plans and projects envisioned by the Company and the reality of the executed works in Malabar. By the time the Company had professional military engineers, it was already losing its hold in Malabar and could not manage the upkeep of many of its settlements. So, it raises the question, how far did the Company make use of the European technical knowledge in Malabar?

\footnotetext{
${ }^{67}$ Fokko Jan Dijksterhuis, 'Duytsche Mathematique and the Building of a New Society: Pursuits of Mathematics in the Seventeenth-Century Dutch Republic' in Cormack L., Walton S., Schuster J. (eds) Mathematical Practitioners and the Transformation of Natural Knowledge in Early Modern Europe (Cham, Switzerland: Springer, 2017), p. 167.

${ }^{68}$ Gommans, Bos and Kruijtzer (eds.), Grote Atlas van de Verenigde Oost-Indische Compagnie, p.177.

${ }^{99}$ Chandra Mukherji, Impossible engineering: technology and territoriality on the Canal du Midi (Princeton: Princeton University Press, 2009).
} 
Or a different question, how successful was the Company in mobilising workforce and resources in Malabar?

A proposal for the reduction in the size of the main fort at Cochin featured regularly throughout the period in the discussions of military engineers and administrators. The final plan (before the city was lost to the English) to accomplish it was prepared in 1782 by surveyor Carl von Krause (see fig. 26)..$^{70}$ The plan proposed to reduce the size of the fort by resizing the gates and boundaries. The plan also indicated a reduction in the number of the houses and settlements inside the fort, something marked by dotted black lines. The figure shows the boundaries of the fort carefully locked so that it could resist any siege. The motives behind such plans were economic and military. The project plans for Fort Cochin were proposed to the High Government in Batavia. But the VOC Directors were not keen to invest in Malabar as it did not generate much profits for the Company. An analysis of the different plans and sketches gives us an impression that most of the proposed plans were not implemented. Such plans bring out the duality of imperialism: the way the European companies positioned themselves in their visual representations was often in sharp contrast to the struggles they had to maintain their territories.

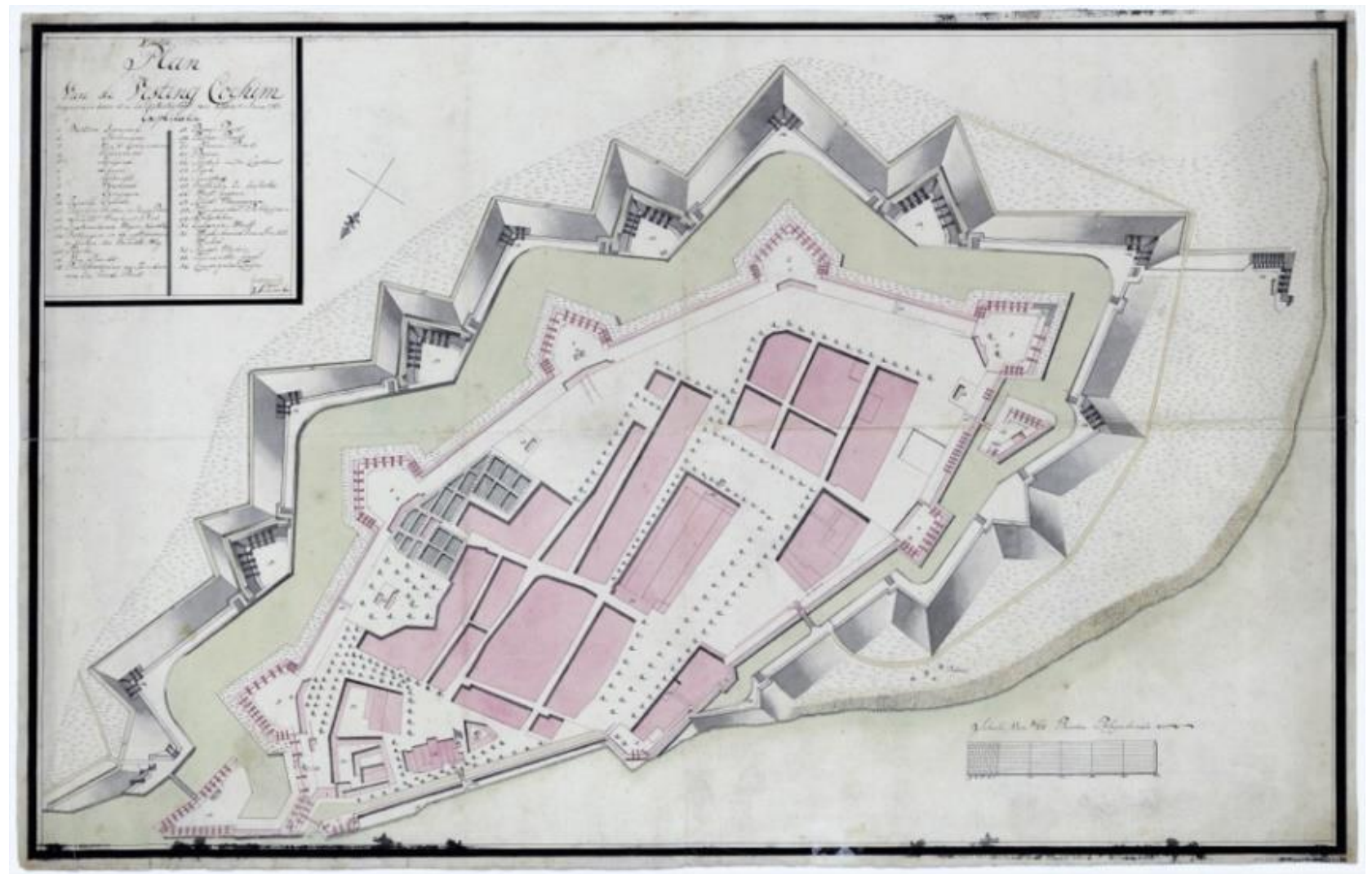

Fig. 26. Plan for the reduction of the size of the fort, 1782 (Courtesy: National Archives, The Hague)

${ }^{70}$ NL-HaNA, Cards Leupe, 4.VEL, inv. 906. 
One of the reasons the fortifications in Cochin needed repair was the regular soil erosion in the region. In 1761, Commander Godefridus Weyerman wrote to his successor about the threat of erosion and the risk associated with the shipyard. ${ }^{71}$ During Weyerman's tenure, a plan was drawn for a shipyard at Calvethy, east of the town of Cochin, by lieutenant engineer Dirck Zijnen. It had descriptive notes on the right side of the document (see fig. 27). ${ }^{72}$ It indicated the need for improving the management of water surrounding the yard. This was reflective of the concerns about constant erosion and flooding in the region caused by the sea and the river Calvethy on the sides of the Cochin town. After all, one of the islands lying across Cochin, was earlier known by the name, Papen Island ('Priests' or 'Papists' Island under the Portuguese), came to be later known among the Dutch as Verdonken Eiland (Drowned Island). What Zijnen proposed in his plan was the construction of several breakwaters and a masonry weir or dam with drainage that could keep the waters from entering the fort (see fig. 27). ${ }^{73}$ But without funding, local labour and a skilled workforce, such plans never materialized. The surveys undertaken by surveyors and military engineers were collaborative efforts to produce practical knowledge of the landscape, waterscape and cityscape of Malabar. Such collaborations did not produce material structures per se, however they solidified European epistemologies of surveying, taxing and privatising the region.

\footnotetext{
${ }^{71}$ G. Weijermans, P. Groot (ed.), Selections from the Records of the Madras Government, Dutch Records No.12: Memoir of Commandeur Godefridus Weijerman delivered to his Successor Cornelis Breekpot on the 22nd February 1765. Copied by the Rev. P. Groot (Madras, 1910), p.19.

72 Plan of Caluetty or shipyard, located East of the City of Cochin. NL-HaNA_4.VEL, inv. 230.

${ }^{73}$ See the maps of 1782 in Gommans, Bos and Kruijtzer, Grote Atlas, pp. 255-56.
} 


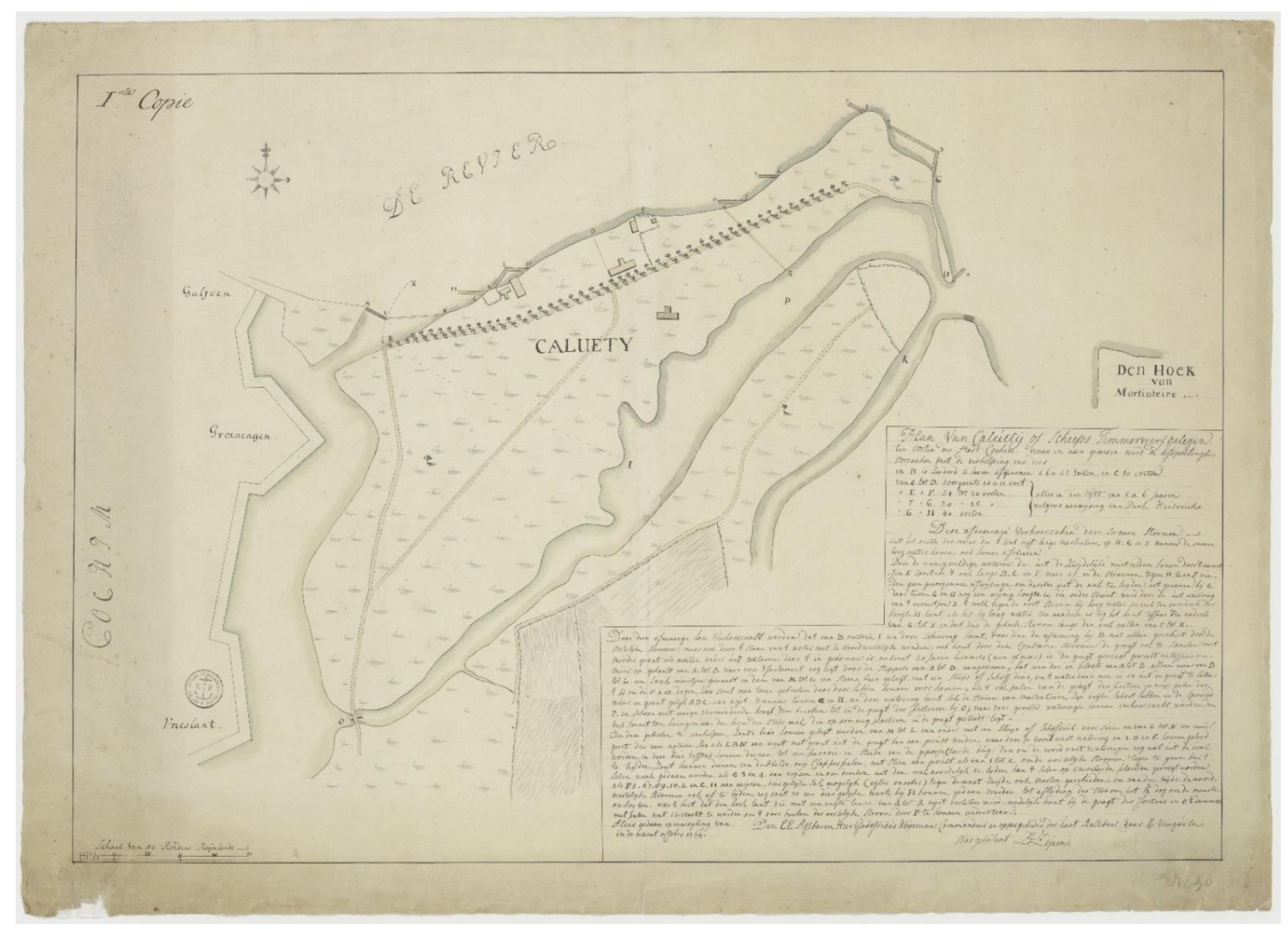

Fig. 27. Plan for the ship dockyard

What can be discerned from the different maps of the VOC period is a gradual increase in the amount of detail and accuracy with which the region of Malabar was being mapped. Two of the stylistic developments in them are the ways in which relief is represented and the colours used to represent them. In the context of sixteenth-century colonial maps of Mexico, Gruzinski argued that it would be a mistake to snub Westernization of space as mere imposition of arithmetic and materialistic conceptions of space. ${ }^{74}$ The introduction of landscapes features like trees, rivers, all in hues of green and water reveals the influence of Spanish painting and engraving. The same could be said about the Dutch Company maps of Malabar. The recurring theme of green agricultural lands and water bodies in the Company plans is an indication of commercial interests. The depiction of rice fields and river navigational routes is a clear indication of how Company's mapmaking focus shifted from simplistic representation to more detailed accounts of the areas owned and their strategic location in relation to other kingdoms and principalities. This trend

${ }^{74}$ Gruzinski, 'Colonial Indian Maps in sixteenth century Mexico’ p. 53. 
developed in tandem with the Company's growing involvement in the political affairs of Malabar. Though the VOC could not achieve a monopoly in Malabar in comparison to its monopolistic positions in Batavia and Ceylon in the seventeenth century, the Company was still a key player in the political scene but did not invest in the upkeep of its settlements. ${ }^{75}$

\section{Conclusion}

The VOC visual representation of Malabar in the form of maps and plans was often representations for, rather than representations of, what it purported to represent. What was lost in this process was the native cultural and political space. The new geographical knowledge made available through maps led to the projecting of the Dutch trading Company's territorial possessions by demarcating their borders vis-à-vis the possessions of its rivals in Asia, which by the second half of the seventeenth century was the English East India Company. Mapping by then had already become a means to concretize the projected imperial territorial ambitions. ${ }^{76}$

As we look at the Dutch maps of Malabar in the seventeenth century, it appears that at first matters of maritime control and settlement were taking precedence over military control and administration of the land. However, later mapping efforts reflected the Company's gradual expansion into the interior of Malabar. Maps gradually became more complex, with features such as rivers, gardens and settlements depicted on them, information that reflected increasing Dutch engagement across the region. With the later maps, navigation, construction and the upkeep of fortresses were of vital importance to the VOC. From defining territories to controlling them, the Company drew up the boundaries of native rulers and chieftains, so that access to lands and property remained strictly under Company's control.

The Dutch Company maps can be understood as forceful expressions of the absolute rule of the VOC administration, even if reality confounded its territorial power. An analysis of Company maps on Malabar from the period reveals their various interests: Company's changing interests in Malabar; structured understanding of the landscape and utilitarian aspects of the acquired region. Land and its resources were printed on maps, and this helps us understand how the landscapes were imagined, surveyed, developed and imperialised. Maps often served as the printed propaganda for the governing body of the Company allowing them to make decisions regarding what was needed to be controlled and where would the Company gamble with its wealth.

\footnotetext{
${ }^{75}$ For a detailed understanding of the relations of the Company with the rulers of Cochin from 1663 to 1795 , see, Hugo K. s'Jacob, The Rajas of Cochin 1663-1720: Kings, Chiefs and the Dutch East India Company (New Delhi: Munshiram Manoharlal, 2000).

76 Thongchai, Siam Mapped, pp. 129-130.
} 
Space was claimed, built, developed, organized and controlled. These were often an extended variant of the nationhood the Republic was aiming to achieve back home.

The VOC maps tended to project the glorious period of seventeenth century and what it meant to be the key mercantile trading company in the world. But the reality on the ground was often at variance with this glorious picture as far as its functioning in Malabar was concerned. Most of the plans and sketches for improving the settlements in Malabar were often delayed or never realized. The projected plans of 1767 were implemented almost forty years after engineer Noodt had completed his survey in the 1720s. Maps and plans not only represented, but also partly created what they pretended to represent. And they were not only (passive) instruments of an already existing corporate policy, but they also shaped and steered it politically.

This chapter has examined: the discourse of territorial surveying of the newly conquered Dutch lands, making of the cultural space 'Dutch Cochin' (the city as the centre of power) and thirdly, the Dutch territorial and visual domination of the region from 1663 to 1795 . To conclude, the chapter has examined the different stages in the Dutch visual representations of Malabar: from the initial transformation of Portuguese cityscapes, to territorial expansion and the inability to maintain the forts and settlements in Malabar. What could be inferred from this analysis is that Dutch creation of Malabar was a process that lasted over the seventeenth and eighteenth centuries. In short, the political space of Dutch Malabar was an ambiguous idea negotiated and renegotiated between the Dutch East India Company and the local rulers of Malabar.

Maps, plans and surveys of Malabar served different purposes for the Company at different time periods. In the beginning, they served as indicators of areas which were then occupied by Portuguese but were needed to be conquered by the Company to establish its monopoly over Iberian trading commodities. In the second half of the seventeenth century, maps catered for the needs of the publishing houses of the Republic bringing them huge profits. Towards the eighteenth century, cartographic information was used as tools to gauge the expenditure on various Company settlements. The continuing depictions of green patches of extended rice fields, Company lands and gardens from the seventeenth century indicated the clear attention given to economically productive zones, a theme which will be examined in detail in the next chapter. The chapter that follows will elaborate on how the agricultural areas owned by the Company after the siege of the lands from the ruler of Calicut were put into use and how the Company officials in Malabar tried to turn attention from trade to landed wealth. 


\section{Chapter Five}

\section{From Pepper to Property: The Company Gardens in Malabar in the Eighteenth Century}

Malabar in the eighteenth century was still an active trading centre despite the changing fortunes of the VOC in the region. With strong English presence along the coast, the VOC had both local and European rivals to deal with in trade and monopoly. By 1750, the Company had been in Fort Cochin for eighty-seven years. By this time, the Company servants had developed their own distinct ways of life in the region. One met men, women and children from all walks of life and from all religious, ethnic and class backgrounds in Malabar: Portuguese, Dutch, French, British, Jew, Casado, Chetti and Baniyas. In such a social milieu, many of the locals tried to work for the Company as soldiers, translators and traders.

Between 1750 and 1795, the time period covered in this chapter, the VOC employed able Commanders in Malabar. But without financial support from Amsterdam and Batavia, the VOC officials could not do much for raising their profit margins. Malabar ceased to bring enough profit for maintaining the Company's settlements, which spread from the north of Malabar to Cannanore in the south. By analysing VOC archival materials on Company owned lands and reports of the Commanders who served in Malabar, this chapter will continue its enquiry into the Company's ways of producing 'bureaucratic knowledge' necessary to control trade and administer territorial possessions. The chapter also tries to understand why the botanical knowledge compiled by Van Reede never found an audience in the settlements in the eighteenth century. As echoed in the Introduction of the thesis, the VOC was primarily concerned with knowledge that could lead to immediate profits. By 1750s, the VOC commanders in Malabar were planning to make the VOC's stay more permanent in Cochin and tried to generate income from land through revenues and profits from the sale of arrack and coconuts. ${ }^{1}$ Despite the efforts of Commanders such as Casparus de Jong and Godefridus Weyerman to buy land for the VOC, the Malabar Command of the VOC did not survive long. The refusal of the High Government at Batavia to support its employees in Cochin experimenting with new ways to generate profits can be considered one of the reasons for the failure of the VOC in Malabar. ${ }^{2}$

\footnotetext{
${ }_{1}$ Anjana Singh, Anjana Singh, Fort Cochin in Kerala, 1750-1830: The Social Condition of a Dutch Community in an Indian Milieu (Leiden: Brill, 2010), p. 74.

2 Ibid, p. 70.
} 
The last chapter examined the various ways in which the VOC visually projected its power over the newly acquired territories. It examined how the VOC undertook a programme of mapping to bring together different strategic economic zones into a system of political surveillance and commercial networks. It also discussed developments in the visual representational techniques of the Dutch territories in the eighteenth century. By the second half of the eighteenth century, the Dutch had a detailed understanding of the landscape of inland Malabar which were subsequently reflected in the maps as Compagnie landen. This visual exercise of power over the territories in Malabar could also be read as the manifestation of imperialist vision of establishing sovereign power to raise additional income from land at a time when the pepper trade was becoming unprofitable.

Building on the previous discussions of botanical and cartographical knowledge produced on Malabar, the present chapter will examine the extent to which Company officials had utilised that knowledge in managing their plantations and estates. In doing so, the chapter will examine the extent to which 'new' knowledge, contributed to the Company's success in Malabar, as measured by the introductions of new species, scientific methods of cultivation and land management. The chapter will also consider the cultural construction of knowledge through the concept of 'go-betweens' and will ask which knowledge aided in territorial and political expansion in Malabar?

To answer the above question, it is necessary to examine the VOC's new role as a landlord in Malabar in the eighteenth century. By examining the official Company correspondences and memoirs of the Dutch Governors stationed in Malabar, this chapter will argue that 'science' was not used as an effective imperial tool by the Dutch in Malabar. Neither the Directors of the Company in Amsterdam nor the Government at Batavia offered patronage for any botanical expeditions or explorations in the Indies in the eighteenth century. The servants of the Company failed to generate income from 'science' for their imperial agenda. In Malabar, the fate of the Company depended on how effectively they navigated the political relations with local rulers. The Company officials stationed in Malabar had a better understanding of land and its profitability than the VOC's administration in Amsterdam and Batavia. Nevertheless, without patronage, they were powerless to take necessary steps to improve the profits from the Malabar settlements. The new cartographic knowledge came of no use in persuading the central administration which had no understanding of land and cultivation in Malabar. 
The primacy of Dutch trade was affected by unfavourable conditions both locally and globally by 1740s. The War of Spanish Succession (1701-1713) witnessed intensive fighting in the Low Countries. The War against France and Spain meant losses in ships, increased expenditure of defensive measures and a fall in the demand of spices coming from the Indies. ${ }^{3}$ Jonathan Israel argues that the year 1740 was a turning point in the Company's trade. The VOC held primacy in the years 1713-40, but was reduced to an intermediary power from 1740 to $1806 .{ }^{4}$ Israel explains this decline in various ways: firstly, the powerful states of northern, central and eastern Europe had adopted aggressive mercantilist policies, effectively shutting out the incoming of Dutch goods into their markets. Secondly, the Dutch share in bulky products from Europe (such as grains, timber, wine etc) declined from 1740. Thirdly, the year 1740 marked the commencement of AngloDutch wars for global dominance; which ultimately reduced the Dutch ability to carry goods on behalf of others. ${ }^{5}$

Most historians have described the conditions of the VOC in Malabar in the second half of the eighteenth century as a state of terminal decline. Ashin Das Gupta's book concludes with the section 'Crisis in Malabar', in which he argues that the period 1740-1800 was 'the last phase of glory' for the Dutch. Dutch historians David Winius and Markus Vink characterised the period between 1748 and 1795 as that of 'disengagement and decline'. ${ }^{6}$ Another Dutch historian, Jos Gommans argues that the mounting pressure to maintain forts and guard posts in Malabar drained the Company's treasury. In the eighteenth century, Malabar employed 1,000 men (in 1735 even 1,395) as compared to 200 in Surat and fewer in Bengal and slightly fewer than 700 in the Coromandel. $^{7}$ In 1753, Malabar had a strength of 1395 VOC employees spread over various settlements with 675 employees in Fort Cochin. ${ }^{8}$ Cochin was categorized as one of the 'least profitable settlements' by the Company. Historian Femme S. Gaastra has argued that there was a scholarly interest among the Directors in Amsterdam and officials in the overseas posts for scientific and botanical exploration in the last quarter of the eighteenth century. ${ }^{9}$ However, the Company did not have the financial means to undertake such scientific enterprises. To gauge the

\footnotetext{
3 Jonathan Israel, Dutch Primacy in World Trade, 1585-1740 (Oxford: Clarendon Press, 1989), pp.359-370.

4 Israel, Dutch Primacy, p.399.

5 Ibid.

${ }^{6}$ George D. Winius, and Marcus P. M. Vink, The Merchant-Warrior Pacified. The Dutch East India Company and its Changing Political Economy in India (Delhi: Oxford University Press, 1994).

7 Jos Gommans, 'South Asian Cosmpolitanism and the Dutch Microcosms in Seventeenth-century Cochin (Kerala)' in Catia Antunes and Jos Gommans (eds.), Exploring the Dutch Empire: Agents, Networks and Institutions, 1600-2000 (London: Bloomsbury, 2015), p.14.

8 Anjana Singh, Fort Cochin in Kerala, 1750-1830: The Social Condition of a Dutch Community in an Indian Milieu. (Leiden: Brill, 2010), p. 23.

${ }^{9}$ Femme S. Gaastra, 'The Dutch East India Company: A Reluctant Discoverer', The Great Circle, Vol. 19, no. 2, 1997, p.116.
} 
significance of the material impact of knowledge-making in the Company activities, the chapter will begin with an analysis of the political and economic conditions of the Dutch in Malabar.

\section{Malabar in the eighteenth century}

In 1741, on behalf of the mercantile community in Calicut, Banichery Ismael, a Muslim merchant in Calicut, wrote to his counterpart Ezekiel Rabbi, a Jewish merchant. He requested the Rabbi to negotiate with the Dutch to release his trading ships that had been captured on their way from Bengal. ${ }^{10}$ The Calicut merchants wanted the freedom to trade between Malabar and Bengal which was made difficult with the establishment of Dutch sovereignty on the coast. The local merchants' plea for exercising their trading right indicates a superior position held by the Dutch as traders in Malabar. This political power held by the Dutch over the territories and waterscape in Malabar changed in due course. The non-centralized political structure was reflected in an uneven distribution of power and wealth among the ruling classes in Malabar. As discussed in Chapter One, the region comprised four main kingdoms of Kollathiri, Calicut (ruled by Zamorin), Cochin and Travancore described by Das Gupta as a "country where wars came easily'. ${ }^{11}$ And, as also noted, the ruler of Cochin was the main ally of the Company in Malabar since the treaty of 1663, after which the Dutch had made Cochin their centre of administration. Eighteenth-century Malabar saw changes in the structures of hegemony. The kingdom of Cochin ceased to maintain its power over the rest of the principalities. While Calicut was destroyed by the armies of Mysore, thekingdom of Travancore rose to prominence. ${ }^{12}$ In the initial years of the Dutch presence in Malabar, Travancore was a small principality. However, in the years 1729-1758, Travancore rose as a major political power under King Marthanda Varma. Through a series of invasions, the kingdoms of Quilon, Kayamkulam, Vadakkumkur and Thekkankur came under control of Travancore. This made the pepper procurement from these regions difficult for the Dutch. ${ }^{13}$ The Company had entered into pepper contracts with the rulers of the four above-mentioned kingdoms and also had forts in Kayamkulam and Quilon. ${ }^{14}$ K. M. Panikker observed that

\footnotetext{
${ }^{10}$ Ashin Das Gupta, Malabar in Asian Trade 1740-1800 (London and New York: Cambridge University Press, 1967), p.2.

${ }^{11}$ Ibid, p.3.

12 On the Mysore invasion of Calicut under Hyder Ali, see, N. Rajendran, 'Background of the Mysorean Invasion of Malabar 1765-66', Proceedings of the Indian History Congress, Vol. 39, no. 2, 1978, pp.613-617.

${ }^{13}$ Das Gupta, Malabar in Asian Trade, p.40.
} 
the loss of independence of the four kingdoms, was the first and the most important blow struck against the Malabar political system. With it went the feudal conception of Malabar polity. The old idea was that the Nayar lords could not be punished even in the case of treason. But Marthanda Varma swept away those notions of chivalry and exterminated without scruple the families that had so long dominated the state. ${ }^{15}$

Once Travancore took control of the annexed regions, Marthanda Varma cancelled his pepper contracts with the Dutch and started selling pepper to non-Dutch traders. In 1735, the Company officials wrote to Batavia alerting them to the threat posed by the newly emerging power in Malabar, Travancore and the support extended by the English Company to Travancore. M.O. Koshy argues that the Dutch were preoccupied with the problems of Cochin and had no knowledge of the South of Malabar and hence did not foresee the expansion of Travancore. ${ }^{16}$ In 1739, Baron Gustaaf Willem van Imhoff (the Dutch Governor of Ceylon) visited Cochin to examine the state of affairs of the Company. In his report to Batavia, van Imhoff expressed deep concern over the Company's existence in the region. ${ }^{17}$ The Dutch attempted to curb the expansion of Travancore, but they were unsuccessful. ${ }^{18}$ In a nutshell, the Dutch troops under Commander Julius Valentijn Stein van Gollenesse surrendered to Marthanda Varma in 1741 (an event celebrated in Kerala historiography as the Battle of Kolachel), after a futile attempt to resist the expansion of Travancore. ${ }^{19}$ Essentially, the Company failed to enter into peaceful negotiations with Marthanda Varma and had to accept his trade agreements.

Around the same time, disagreements arose between the Company and its ally, the ruler of Cochin. In a letter written in 1757, the King of Cochin requested the Company to support him in his campaign against Travancore. The request was refused by Van Gollenesse on the grounds that the Cochin ruler had not helped the Company in times of crisis, and so could not expect any help in return. The ruler then wrote to Batavia accusing the Company of betrayal 'of an old friend and ally, among other Malabar kings, even after the repudiation of all treaties'. ${ }^{20}$ In another letter written to Batavia in 1772, the ruler said that if the Company assisted in conquering the lands

\footnotetext{
${ }^{15}$ K. M. Panikker, Malabar and the Dutch (Bombay: D.B. Taraporevala Sons and Co, 1931), p.62.

${ }_{16}$ M. O. Koshy, The Dutch Power in Kerala (1729-1758) (New Delhi: Mittal Publications, 1989), p.56.

${ }^{17}$ Koshy, The Dutch Power in Kerala, p.59.

18 The Dutch attempts to curb the Travancore power is examined in detailed in many works. See, K. M. Panikker, Malabar and the Dutch; Hugo s', K. Jacob, 'De VOC en de Malabarkust in de 17eeuw', in M. A. P. Meilink- Roelofsz (ed.), De VOC in Azië(Bussum: Fibula-Van Dishoeck, 1976); Koshy, The Dutch Power in Kerala.

${ }_{19}$ Scholars have expressed their disagreement with the term 'Battle' of Kolachel because the Dutch-Travancore encounter was more of a confrontation than a battle in its literal sense. For instance, see the arguments of M. O. Koshy in The Dutch Power in Kerala, p.71.

${ }^{20}$ Letter V, Letters from Cochin Rajas to Batavia, Records in Oriental Languages-Cochin State Book II (Ernakulam: Cochin Government Press, 1946), p.4.
} 
between Ponnani and Chettuvay, the ruler will be happy to pay Rs1000 annually to the Company. ${ }^{21}$ Historically, the relation of the Company and the ruler of Cochin was of mutual co-dependence, more so because of their common rivals in Malabar. Despite brief periods of hostilities in the seventeenth and eighteenth centuries, the ruler of Cochin and the VOC have depended one each other for sustaining their political sovereignty. It should be noted however that the VOC did not experience financial problems solely because of the changes in political hegemony.

In Malabar, the VOC only held monopsony rights for pepper. The state of the Company trade in Malabar was such that the Company incurred more expenditure than income. The steep rise in the price of pepper, centralization of the kingdom of Travancore and the weakening role of the ruler of Cochin led to a dismal picture for the Company's dream of a pepper monopoly. The fluctuations in pepper trade affected the intra-Asian trade in which the Company had been actively involved since the seventeenth century (as discussed in Chapter One). Along with the dwindling profits from intra-Asian trade, the changing conditions in the European Asian trade also had a role to play. From about 1680 onwards, Indian textiles became very popular in Europe. The demand for coffee (from the Arabs first, then later from Java) and tea from China increased enormously around 1700. The Dutch East India Company did not have monopoly on either of these items. While trade and shipping were growing, the competition in the international market was reducing profit margins. ${ }^{22}$ Though pepper production in Malabar continued at a steady rate, the quantity and the price at which the Company bought pepper from the coast increased with competition from the English East India Company. Pepper was grown all along the coast, but the concentration of production was inland, at the foot of the Western Ghats. ${ }^{23}$ Pepper vines were planted in orchards and supported by mango and areca nut trees. A healthy vine could live for twenty-five years. ${ }^{24}$ In his travelogue, Francis Buchanan wrote that before the invasion of Hyder Ali (in 1764), Malabar produced 15,000 Candies of 6401b. of pepper annually. ${ }^{25}$ In Travancore, he observed that the tribes of the hills planted rice, cowpea, gingelly, tapioca, yams, cucurbits, brinjal, chilli and plantain. ${ }^{26}$ The Malabar described by Buchanan in the beginning of the nineteenth

\footnotetext{
${ }^{21}$ Letter VII, Letters from Cochin Rajas to Batavia, p.8.

22 Gaastra, 'The Dutch East India Company', p.112.

${ }^{23}$ Western Ghats is one among the eighteen biodiversity hotspots in the world. Springing from the Arabian Sea coast to the heights of over $2,000 \mathrm{~m}$, and having rainfall ranging from less than 1,000 $\mathrm{mm}$ to over $6,000 \mathrm{~mm}$, the landscapes in the region are very heterogeneous. For a detailed ecological history of the region, see M. D. Subash Chandran, 'On the ecological history of the Western Ghats', Current Science, Vol. 73, no. 2, Special Section: Biodiversity of Western Ghats, 25 July 1997, p.149.

${ }^{24}$ Das Gupta, Malabar in Asia Trade, p.21. The pepper fruit was plucked while green, usually in the months of October or November. Once plucked, the fruit was laid out in the sun to dry. After a few days, the colour would change to black. Only then was the fruit considered fit for export.

${ }^{25}$ Ibid, pp.21-23. For a complete travelogue account of Francis Buchanan on Malabar see, Frances Buchanan, $A$ Journey from Madras through the Countries of Mysore, Canara and Malabar, Vols. 1-II (London: W. Bulmer and Co., 1807). ${ }^{26}$ Chandran, 'On the ecological history of the Western Ghats', p.149.
} 
century was vastly different from the Malabar in the 1740 s. $^{27}$ Das Gupta noted that 'though numerous contemporary travellers described the plantations, no one discussed their ownership'. ${ }^{28}$ Das Gupta argues that, in the 1740s, pepper was cultivated by poor farmers (often referred to as arme landman, kleine landman or peperboeren in Dutch records) holding small tracts of land. The Company did not own the production of pepper in Malabar. ${ }^{29}$ In 1740, the Company still enjoyed a substantial revenue from pepper as Travancore had not established its monopoly yet. Between 1755 and 1756, the Company collected 1,494,451 lbs. from Travancore, 533,505 lbs. from Cochin, 21,181 lbs. from Cranagnur and 153,000 lbs. of Cannanore pepper, making a total of 2,202,837 lbs. from Malabar. ${ }^{30}$ The next section will elaborate on how the Company officials in Malabar tried to cope with the fluctuating income from trade.

\section{The VOC as a landheer (landlord)}

The reduction in income from the pepper trade caused worry for the Directors in Amsterdam and for the officials stationed in the settlements. The VOC commander, Caspar de Jong (1757-61), realized that the 'golden spice' (pepper) for which the Dutch had exhausted their resources in Malabar was no longer dependable as a source of revenue. In 1761, de Jong wrote that

....the income from land is the source through which the company maintained itself on the coast. The income from trade is fluctuating and attention to revenue from land would yield better results and therefore deserves better attention. ${ }^{31}$

Dutch Commanders, mainly de Jong and his successor Godefridus Weyerman (1761-64), both brought about changes in the Company policies so that it could generate revenue from non-trade sources. Both de Jong and Weyerman implemented new policies that changed the Company's focus from pepper trade to landed property. Their tenures saw increased revenue from Company lands. A special committee under the leadership of Silvester Mendes, head of the Toepass

\footnotetext{
${ }^{27}$ Das Gupta, Malabar in Asia Trade, p.23

28 Ibid, p.21.

${ }^{29}$ Ibid.

${ }^{30}$ A. Galletti, A. J. van der Burg and P. Groot, The Dutch in Malabar (Madras: Government Press, 1911 reprint Delhi, 1984), p.35.

${ }^{31}$ Casparus de Jong had served in Ceylon and was acquainted with the ways of the Company's land management there. For his see, Memorie nagelaten door den afgaande E.E. Commandeur Casparus de Jong aan desselfs vervanger den E.E. agtb heer Godefridus Weijerman gedagteekend den 7 maart 1761, Selections from the Records of the Madras Government: Dutch Records No. 11, P. Groot, (ed.), (Madras: Government Press, 1910), p.42.
} 
community, was made to survey the company's lands and gardens in the late $1750 \mathrm{~s} .{ }^{32}$ This is one instance where there is evidence of the Company's reliance on local men for land surveys. Thus, the role played by locals in the early modern knowledge-making cannot be overlooked. It was crucial for the VOC to create administrative knowledge through surveys which existed on the support of 'friendly natives' to further their imperial agenda.

The imperial policy was witnessed by the manner in which the VOC added new territories to its possessions through numerous land revenue contracts with local ruling communities, of which the Payancheri Nayars were the most prominent. ${ }^{33}$ These contracts often included the administration and protection of those living on the land, that is, they extended the Company's judicial and fiscal administration over such lands and people. At times, these policies meant that if landowners could not prove their ownership with any document, the lands were automatically annexed and brought under the jurisdiction of the Company. A list of the Company's landed assets on the Malabar coast (dated 1740) records gardens around Pappinivattom as Company owned lands. As noted in the previous chapter, the Company occupied this land after a political siege and surveyed its economic potential. ${ }^{34}$ Just to summarise, Pappinivattom comprised of 18 half-villages, a plot of land that stretched from the north of Cranganore to the south of Pappinivattom (that earlier belonged to the Calicut ruler). Company maps recorded klapper thuijnen (coconut plantations) and reysvelden (rice fields) in these villages. These productions generated considerable income for the Company. Julius Valentyn Stein van Gollenesse, Commander of Cochin (17341743), noted in his memoir, that Pappinivattom 'has been much improved since our occupation by the discovery of many misappropriated lands, gardens and rights and produced 734 rix dollars in cash and 235 parras of rice. These revenues have since been increased by 170 Cranganore parras and 11 gold fanam'. ${ }^{35}$

In 1755, the Payencheri Nayars ${ }^{36}$ (who resided in the region) agreed to pay half of the revenue generated from a section of the land, a sum fixed at one-tenth of the revenue from cultivated products. They also agreed to consign 523 parras of rice and $4921 / 2$ golden fanums to

\footnotetext{
32 Singh, Fort Cocbin in Kerala, p.74. But later discrepancies were found in the survey and another committee was set up with Dutch officials. This could also indicate the lack of trust the Company had in non-Dutch persons. In a report from 1781, the then Commander Moens talks about appointing an inspector (tree-teller) to inspect the gardens and fields mainly to make sure the renters are keeping the Company's land in good condition.

33 Singh, Fort Cochin in Kerala, p.74.

34 Papponetty Boundary Settlement dated 26the May 1717, Cochin records, No: 101, Tamil Nadu State Archives, TSA, Chennai.

${ }^{35}$ Memorie van Overgave van Gollenesse dated 1743, p.63 in The Dutch in Malabar being a Translation of Selections nos. 1 and 2 with Introduction and Notes. Selections from the Records of the Madras Government. Dutch Records no. 13, A. Galletti, A.J. van der Burg, and P. Groot (eds.), (Madras: Government Press, 1911).

${ }^{36}$ Payencheri Nairs belong to a family of land-owning feudal lords who resided in the district of Payencheri that lay between the forts of Cranganore and Chettuwa. For more on their history, see MvO Adriaan Moens dated 1781, p.134.
} 
the Company annually. The same year they offered the Company half of the revenue from the whole territory indicating the expanding sovereignty of the Company and the dependence of the locals. In return, the Company was to protect them against the Calicut ruler. As discussed by Catia Antunes, the VOC was a quasi-state which had powers to wage wars, control land and build forts in the overseas settlements. ${ }^{37}$ In Malabar, the VOC was not merely a trader, but a major political power in the eighteenth century.

De Jong's memorandum written in 1761 stated that from land alone, Company income rose from fl. 16,657 to fl. 47,063 in four years. ${ }^{38}$ According to de Jong, the villages of Pappinivattom brought in approximately fl. $2000-4000$ per year in 1758-59 as against only 9,134 in 1741-42. ${ }^{39}$ De Jong wrote to the High Government at Batavia about the Company's absolute authority and unchallenged claims over the produce from these lands. ${ }^{40}$ Company maps show this region as 'Conquest Paponetty' (this is the Dutch version of Pappinivattom), as it was one of the earliest successful attempts at seizing cultivated property in Malabar. The lands were seized and the Calicut ruler's army could not break the stockade built by the Company in Pappinivattom (as seen in the military plan of the stockade in fig. 25 in Chapter Four). The VOC demarcated lands and separated them from the neighbouring territory belonging to the landlord of Chettuwa and the kingdom of Cranganore.

Apart from the lands in Pappinivattom, the VOC owned gardens in Cochin and its surrounding islands. During de Jong's tenure (1757-61), the Company extended its legal authority over the lands outside the area of Cochin (see Maps 3 and 4). ${ }^{41}$

\footnotetext{
${ }_{37}$ Catia Antunes, 'Birthing Empire: The States General and the Chartering of the VOC and the WIC' in René Koekkoek, Anne-Isabelle Richard and Arthur Weststeijn (eds.), The Dutch Empire between Ideas and Practice, 1600-2000 (Cham: Springer International Publishing, 2019), p.20.

38 Singh, Fort Cochin in Kerala, p.74.

${ }^{39}$ For the revenues in the year 1741-42, see MvO Van Gollenesse dated 1743, p.19 and Singh, Fort Cochin in Kerala: 73. This work has a detailed discussion on the policies adopted by Commanders Casparus De Jong and Godefridus Weyerman to expand the Company's possessions in the Malabar coast.

${ }^{40}$ Anjana Singh, Fort Cochin in Kerala 74.

${ }^{41}$ A copy of Jan Willem de Graaf's general map of the coastal lands of Malabar prepared in 1767. This copy was made by H. A Heidenreich, who was stationed in Ceylon (1770-1790) as a gunner and later in the rank of lieutenant in the service of the Company. Image reproduced from Jos Gommans, Jeroen Bos and Gijs Kruijtzer (eds.), Grote Atlas van de Verenigde Oost-Indische Compagnie: India, Persia and Arabian Peninsula (The Hague: The National Archives, 2014), pp. 206-207 and 198-199 (Author's photos).
} 




Map 3.The VOC map indicating the region Pappinivattom (written as Paponnetty in Dutch records). The cultivated fields can be seen in green along the inland river (Courtesy: Reproduced from De Grote Atlas, The Hague)

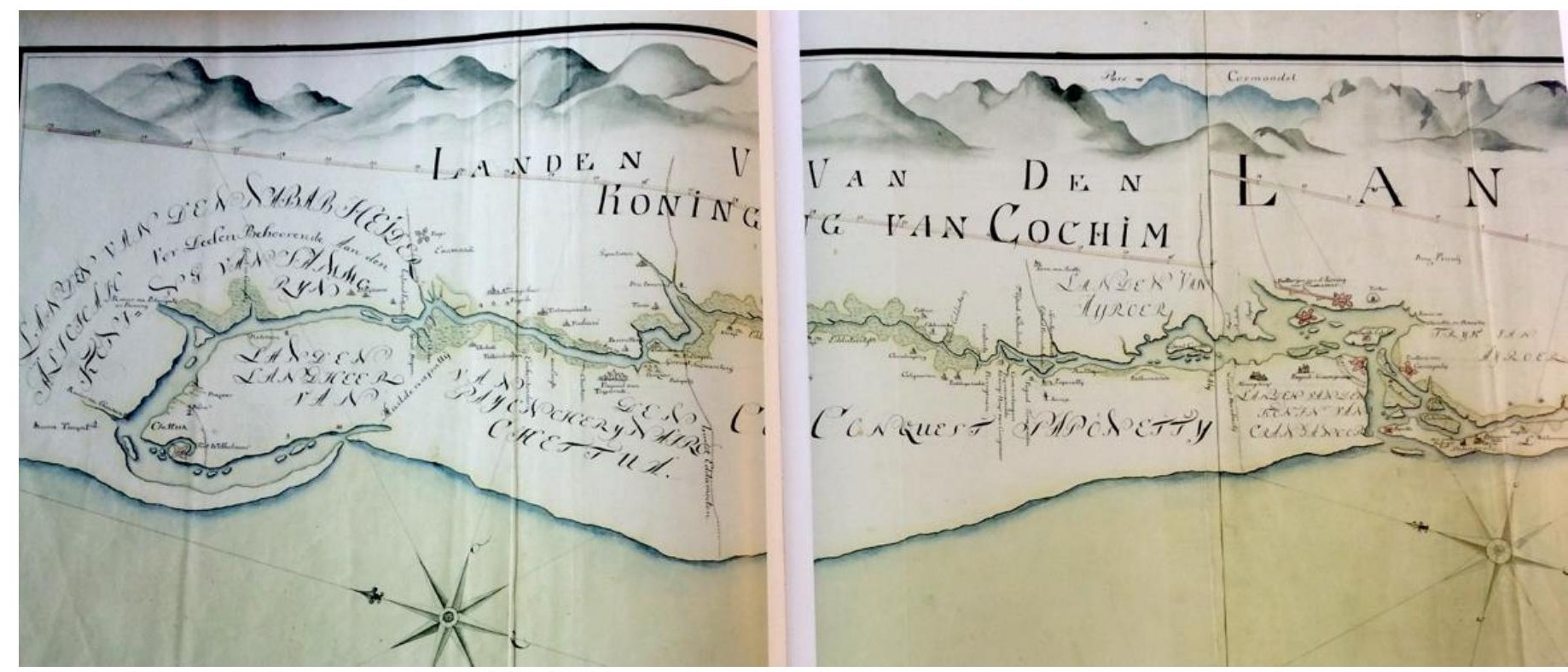

Map 4. This is another sketch of the lands owned by the VOC based on which the above maps were prepared.

(Courtesy: Reproduced from De Grote Atlas, The Hague)

Commander Godefridus Weyerman, who succeeded de Jong, wrote that soon after he took up the office of commander in 1760, he heard about the land and saltpans 'discovered' at Chettuvay, from which the Company had not been getting any income so far. He was surprised that these 
commercially viable lands were not taxed and leased out earlier. So, after assuming his post in Cochin, he had these lands surveyed and leased, from which Company generated income in the following years. ${ }^{42} \mathrm{He}$ also confiscated the lands of rulers who did not have documents to show ownership.

Anjana Singh argues that a comparison of the income books of the Company for the year 1755-1756 and 1759-1760 confirms an increase in the income generated from non-trading activities. This included leases of the lands, gardens, islands, saltpans, fruit-bearing trees and the farms of tolls or taxes on the river (shipping and fishing) and excises on the sale of arrack and tobacco. ${ }^{43}$ In the years 1755-56, the income from all forms of revenues, tolls and land tax, amounted to fl. 70,516. In the years 1759-60 it increased to fl. 82,860; amounting to $31 \%$ and $22 \%$ of the gross profit of Company's income in those years respectively. Thus, from the years 175564, there was a steady interest in the revenue generated from the land in Malabar. Rice cultivation was significant for the Company's revenue. Historian Sinappah Arasaratnam argues that there was a shortage of rice production in South Asia in the second half of the eighteenth century. ${ }^{44}$ In the 1780s crisis, marked by a rise in population, settlements like Ceylon were unable to produce enough food for their inhabitants, resulting in increased rice imports from Bengal, Coromandel (south eastern India) and Java. As a result, the price of rice increased, and it became harder to obtain rice from abroad as greater priority was given to rice imports from Surat and Malabar. ${ }^{45}$

In 1781, Dutch Commander Adriaan Moens wrote in his Memorandum that the possessions of the Company on this Malabar coast consist of forts, buildings, and the lands either taken from the Portuguese or conquered since'. ${ }^{46}$ The continuous preoccupation with the legacy left by the Portuguese in urban forms and through land management practises, can be discerned from the Dutch activities on the coast. By 1781, the Company-owned at least 55 gardens and nine islands are mentioned that cultivated rice and other fruits (see Appendix V).

Anjana Singh's discussion of land management paints a bright picture of efficient Dutch Commanders who were actively involved in generating income from land revenue. This chapter however argues that despite rising income, the Company still faced many problems. For example, in 1777, Hyder Ali (the ruler of Mysore, now in the state of Karnataka) invaded the region and the Company ceased to receive revenues from the Province of Pappinivattom, which was a major

\footnotetext{
42 Singh, Fort Cochin in Kerala: 84.

${ }^{43} \mathrm{MvO}$ of Adriaan Moens dated 1781, p.204. Also see, Singh, Fort Cochin in Kerala, p. 75.

${ }^{44}$ Sinappah Arasaratnam, 'The Rice Trade in Eastern India 1650-1740', Modern Asian Studies, Vol. 22, no.3, 1988, p. 537.

45 Pim de Zwart, 'Globalization and the Colonial Origins of the Great Divergence: Intercontinental Trade and Living Standards in the Dutch East India Company's Commercial Empire, c. 1600-1800', PhD Thesis, Utrecht University, 2015, p.113.

46 See MvO Adriaan Moens dated 1781, p.204.
} 
source of land revenue. ${ }^{47}$ These lands were listed as not generating revenue in Moens's memoir (1781) to Batavia:

A piece of land on the other side of Aycotta.

A piece of land near Manicoorde.

A piece of land on the shore near Aycotta.

A piece of land lying near lllewade.

A piece of land at St. Jago.

A piece of land at St. Andries.

A piece of land on the north side of Kastella.

Two pieces of land lying opposite the post Aycotta.

A piece of land at Aycotta.

A piece of land also lying near Aycotta.

A piece of waste land behind the post Aycotta.

A piece of land lying near the post Manicoorde on the sea-shore.

Some little pieces of land at Calichery Bitsjur.

A piece of land on the "plain" near the Company's Outside Garden. Some little pieces of land in the Illawada farm.

A piece of land lying at Baliaporte.

A piece of land lying east of the Company's Outside Garden.

A piece of land lying next the one just mentioned. ${ }^{48}$

Also, for the Company it was difficult to manage its property that lay scattered across the Malabar coast. In 1781, for example, Commander Moens wrote to his successor, Gerard Van Angelbeck, that 'our landed property lies scattered everywhere, both in Travancore and in Cochin territory. This constantly causes trouble between the inhabitants on both sides, and especially with the renters, who lease the said fields and gardens. ${ }^{49}$ He further added that

at the northern and southern extremities of the island of Baypin (Vypeen) are two strips of land belonging to us (Company), while the rest of the Baypin belongs to the King of Cochin. To the east of this town, about as far as a cannon carries, lies the territory of the King of Cochin. To the south of the town also our territory does not stretch beyond the cannon range. To the north and the west, we are bounded by the river (backwater) and the sea respectively. The islands in the mouth of the river, of which Bendurti (Vendurti) is the largest, also belongs to us and formerly also belonged to the Portuguese. Further we have land in the middle of Travancore as far as Coilon (Quilon), in various pieces, scattered here and there..$^{50}$

\footnotetext{
${ }^{47}$ Ibid, p.227.

${ }^{48} \mathrm{MvO}$ Adriaan Moens dated 1781, Appendices.

${ }^{49}$ Ibid, p.207.

${ }^{50}$ Ibid 207-208.
} 
The political borders were thus not as well-defined as the Company would have liked them, hence the leases and tenants and the Christians of the Company were spread across the coast and lived under the jurisdiction of other rulers. However, the uneven distribution of the Company lands is not discernible from the map showing the Company gardens discussed in the previous chapter (Map 2). Dutch maps often pictured a Malabar neatly divided across the various powerful kingdoms and ruling houses including the VOC lands. Moens summarized that the Company property (if not scattered) would be 'a fine bit of land' ${ }^{51}$ This was because the Company found it difficult to navigate across the political divisions and diverse administrative units which was beyond the uniform plan and surveys of the Company administration. He also proposed that the Company should consider exchanging its pieces of land in the territory of Travancore for land that bordered the Company's fort in Cochin. The second option he proposed was that if the ruler of Travancore did not agree to the exchange of territories, the Company should sell these territories to Travancore for a sum proportionate to the annual revenue derived from these lands. ${ }^{52}$ Moens's words reflect a strenuous period in which the Company struggled to maintain its properties stretched across Malabar. The VOC was not interested in land development, but in the revenue that it generated from other sources. Land as a commodity was only attractive if it could generate income and be managed in close proximity.

It is also worthwhile to notice here that most of the changes in the Company policies were adopted by the Commanders in Malabar. There were no official orders issued from Batavia or Amsterdam for extending the Company's Malabar possessions. It was mainly due to the efforts of Commanders de Jong and later Weyerman, who foresaw the profitability of land, that the Company assumed the role of a landlord in Malabar. The VOC Directors or Governor-General in Batavia was not keen to convert Malabar into an imperial territory, as they had tried (and succeeded) in Batavia in the eighteenth century. To sum up, the company underwent what Singh calls a 'metamorphosis from a pacified merchant-warrior to a landlord' which imposed and collected excises, customs and taxes, and claimed judicial rights on lands in Malabar. ${ }^{53}$ This metamorphosis was largely possible due to the initiatives of Company officials who were stationed in Malabar rather than as a result of the official changes in the VOC policies from the metropole. The next section will examine the VOC land leases.

\footnotetext{
51 Ibid.

52 Ibid, pp.208-209.

53 Singh, Fort Cochin in Kerala, p.89.
} 


\section{Company's Lands and Laws}

The traditional land system in Kerala is called a janmi-kudiyan-sampradayam (landlord-leaseholdersystem or janman-kanam-maryadai (hereditary right-mortgages-custom). ${ }^{54}$ This was different from Dutch and Portuguese land ownership. The landlord held a janman (hereditary right), i.e., the landlord came to own land by inheriting it from his predecessor who had held the land. In this sense, the right over land was autonomous. The landlord loses his right only if he transfers or sells his land. The new owner must then pay rent or dues because he does not come to own the land as a birth right. ${ }^{55}$ As the Portuguese opened new ocean routes, they introduced a Roman model of land settlement and colonization. The Portuguese who travelled to serve the crown, trade and settle in Asia in the early modern period, shared an attachment to the land, as well as a sense of ownership of these lands. Although expansion towards the East had different purposes, agricultural and settler values reappeared..$^{56}$ The European trading companies often brought the system of land management to the areas they settled.

To understand the nature of land leases followed by the VOC in Malabar, it is important to understand the nature of land leases in the Dutch Republic during that time. In the sixteenth century, land leases in Holland were introduced for a fixed number of years (tijdpacht). Once the lease ended, a new deed was drafted. During the tenure, ownership remained with one tenant while the rent could be changed with the general trends in the market. ${ }^{57} \mathrm{~A}$ land lease agreement included the measurements of the plot, rent, years of lease and the fertility of the ground. ${ }^{58}$ By the seventeenth century, printed land leases had become standardized in the Republic. In Malabar, the leases were agreed upon each year on the last day of August (this was in connection with the rice harvest around the month of August).

From the time of de Jong, the tenure of land leases in Malabar was extended. Most of the Company lands were leased out for ten-to-twenty years. One of the reasons for this could be the maintenance of stability in the ownership and revenue for the Company. The other reason could be the understanding of the duration of rice harvest which occurs only once a year. Accordingly, land lease agreements for $1756-1765^{59}$ and $1781-1800^{60}$ were leased for twenty years as opposed to

\footnotetext{
54 The traditional land system in Kerala is examined in detail in K.N Ganesh, 'Ownership and control of land in medieval Kerala: Janman-kanam relations during the $16^{\text {th }}-18^{\text {th }}$ centuries', The Indian Economic and Social History Review, Vol. 3, no. 3, 1991, pp.299-321.

55 Ganesh, 'Ownership and control of land', p. 300.

${ }^{56}$ Ines G. Zupanov and Angela Barreto Xavier, 'Quest for Permanence in the Tropics: Portuguese Bioprospecting in Asia (16-18 ${ }^{\text {th }}$ centuries)', Journal of the Economic and Social History of the Orient Vol. 57, 2014, p.511.

57 J. Kuys and J. T. Schoenmakers, Landpachten in Holland, 1500-1650 (Amsterdam: Historisch Seminarium van de Universiteit van Amsterdam, 1981), p.24.

${ }^{58}$ Schoenmakers, Landpachten in Holland, p.25.

${ }^{59}$ Conditions of Lease $1^{\text {ST }}$ January 1756 to $31^{\text {st }}$ December 1765, Cochin records, No.6, TSA, Chennai.

60 Twenty years of leases of Co's gardens and fields 1781 to 1800 , Cochin records, No.1180, TSA, Chennai.
} 
agreements earlier in the century, which were for a shorter tenure. ${ }^{61}$ With time, it seems that the Company had a greater understanding of the harvest from these lands; rice was harvested only once a year and coconut trees twice a year. The European ownership of land resulted in the expansion of the cultivation of garden crops like coconut and pepper.

\section{Coconut Trees}

Coconut cultivation spread in the coast areas, where the sandy soil was extremely suited for the crop. $^{62}$ In the Memorandum of the Company gardens, there is a clear indication that the productivity and revenue of the lands and gardens were based on the number of coconut trees and the quantity of rice harvested from them (see Appendix V). Predating these records, Ines Zupanov and Barreto Xavier have argued that during the Portuguese period in Malabar (from 1500 to 1660), coconuts, tobacco, and rice became crucial cash crops. This is apparent from acrimonious disputes between the Jesuit settlements in Malabar and Goa over the three villages in Salcette (Ambelim, Velim, and Assolna). ${ }^{63}$ Native to the coast and adorning the landscape, coconut trees painted a perfect picture of the tropics. A seventeenth-century Jesuit agronomical treatise, the Arte palmarica, reflects on the Portuguese economic approach to the scientific cultivation of coconut trees. The work of an anonymous Jesuit, it is a manual on selecting, planting, and tending coconut palm trees in order to obtain the most fruit possible from each tree. ${ }^{64}$ The Dutch also focussed on coconuts. For example, the Hortus Malabaricus begins with a section on the cultivation of coconuts (Thenga in Malayalam, cocos nucifera L.) and contains a detailed discussion on the crop. Contrary to other plants discussed in the work, the descriptions and engraving of coconut are detailed and exquisite (see fig. 28). ${ }^{65}$ A description from the Hortus Malabaricus is as follows:

This [coconut] tree is very voracious, especially that which grows in salty soil and near the sea. That which grows in mountainous regions is less prolific and gives less fruits or Cocos....It is observed that this tree in the third year after sowing (it) is clothed with branches which have grown to the right size, and from that year branches begin to fall and stand up to the height of one and half or two men....The root boiled in water with dry ginger and drunk is useful in warm fever, the same well crushed and decoction made with the oil of the fruit is employed in washing the mouth for blisters arising in the gum; the

\footnotetext{
${ }^{61}$ Conditions of lease 1707 to 1710 , Cochin records, No: 7, TSA, Chennai.

${ }^{62}$ Ganesh, 'Ownership and control of land', p.305.

${ }^{63}$ Zupanov and Xavier, 'Quest for Permanence in the Tropics', p.531.

${ }^{64}$ Ibid.

65 Ibid, p.8-10.
} 
juice squeezed out from tender branches and mixed with a little honey is applied to eyes in a lotion to soothe pain, juice of leaves with oil of the fruit or coco, given in decoction helps in haemorrhages. ${ }^{66}$
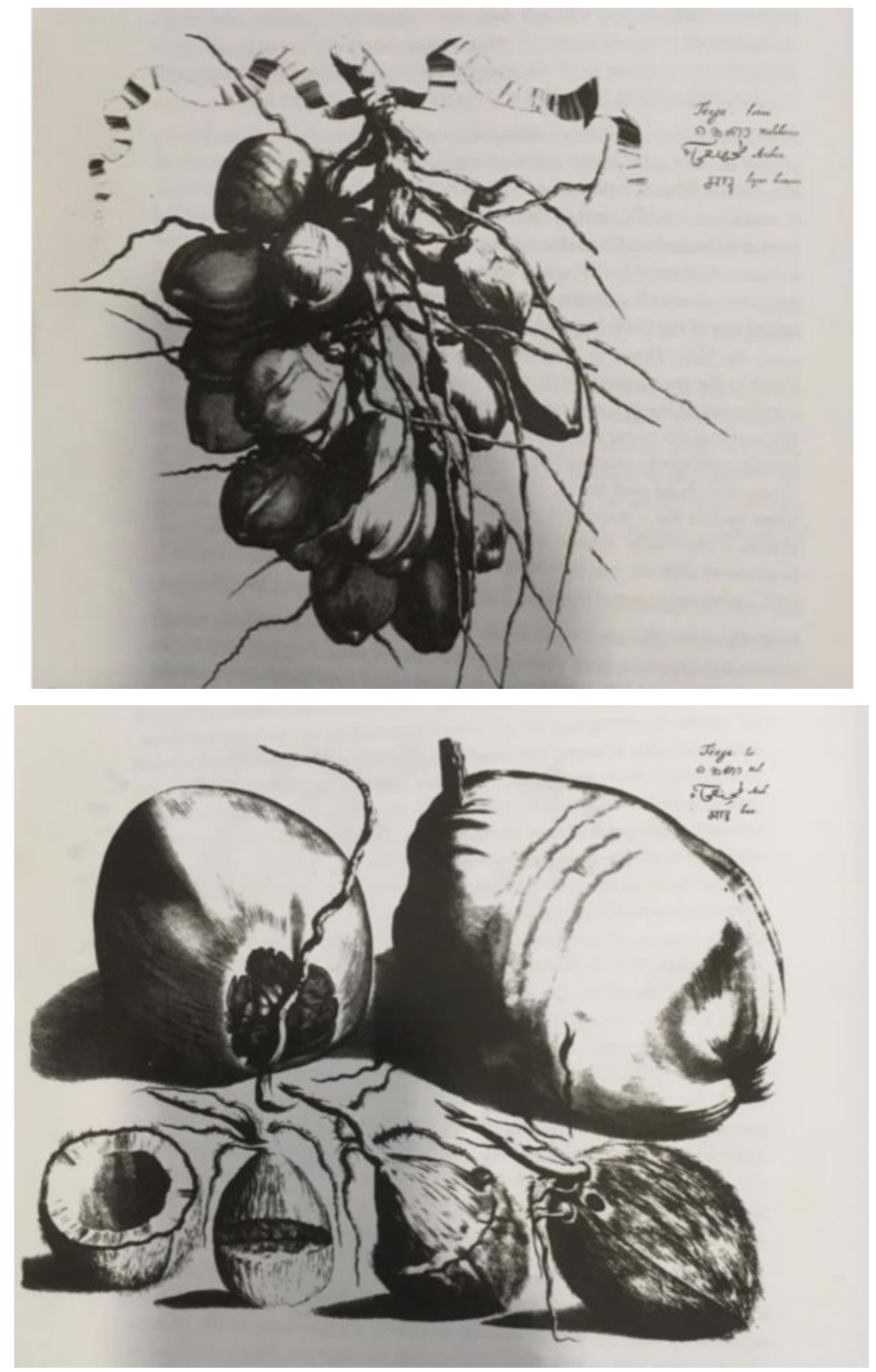

${ }^{66}$ Van Rheede's Hortus Malabaricus English Edition With Annotations and Modern Botanical Nomenclature, Vol. 1, by K. S. Manilal (Thiruvananthapuram: Kerala University Press, 2003), p.12 
Fig. 28. Copperplate engravings of coconuts from the Hortus Malabaricus Vol. I (Tabs 3 and 4) (Courtesy:

Reproduced from the Hortus Malabaricus, Vol. 1)

Since the compilation of the Hortus Malabaricus had a medical focus, the importance of it as a work of economic botany and as a manual for the cropping patterns in Malabar was not fully explored by the VOC. Also, since the tree only grew in tropical climates, it was not a sought-after specimen for European herbariums.

All leases of Company lands included information on the number of coconut trees on them. One of the clauses of the land lease was 'without overexploiting the coconut trees, none will be felled without special license of the overseers and it shall be substituted ${ }^{67}$ Coconut trees were of value to the Company not only as commodities of local trade, but also as a profitable commodity of the intra-Asian trade. Since coconut trees could not be grown in the northern areas or away from the coast, they were highly valued in the inland regions of South Asia. The archival records of voyages contain evidence of Dutch ships carrying kokosnoot (coconut in Dutch), klapperolie (palm oil) from Malabar to Ceylon. A ship that reached Ceylon would then sail to Cape or Batavia. For example, in 1761, the Dutch ship, Johanna Catharina carried 5000 coconuts and 2,591 cans of palm oil to Ceylon each valuing 153 and 1.268, 11 guilders respectively. ${ }^{68}$

In a report, Commissioner Hendrik Zwaardecroon (1697-98) noted that alongside leases, the Company also received revenue from the farming and sale of arrack in Cochin and Cranganore. ${ }^{69}$ Hortus Malabaricus elaborates on the liquor, known locally as suri, noting that coconut trees produce the 'liquor Suri which is a drink like wine having inebriating power, is of pleasing taste, is a bit sweet, slightly salty and slightly acidic. ${ }^{, 70}$ The by-products from coconut, like arrack, were traded by the Dutch to Ceylon. Similar to Malabar, Alicia Schrikker notes that in Ceylon, the Company had turned the coconut industry to its advantage by taxing coconut by-products, such as arrack and coir, as well as their transportation. ${ }^{71}$ Archival records indicate the trade of coconuts and its by-products from Ceylon to Coromandel (south eastern India). ${ }^{72}$ In Malabar, free-burgers ${ }^{73}$

\footnotetext{
${ }^{67}$ Conditions of Lease $1^{\text {ST }}$ January 1756 to $31^{\text {st }}$ December 1765, Cochin Records, No. 600, p.8320, TSA, Chennai. For the other clauses of the land lease, see Appendix V.

68 Boekhouder-Generaal Batavia, Huygens Institute for the History of the Netherlands (accessed online https://bgb.huygens.knaw.nl/bgb/voyage/7194 20 March 2020).

${ }^{69}$ Conditions of Lease $1^{\text {ST }}$ January 1756 to $31^{\text {st }}$ December 1765, Cochin Records, No. 600, p.8320.

${ }^{70}$ Van Rheede's Hortus Malabaricus, Vol.1, p.7.

${ }^{71}$ Alicia, F. Schrikker, Dutch and British colonial intervention in Sri Lanka c. 1780 - 1815: Expansion and reform (Leiden and Boston: Brill, 2007), p.66. In the case of Ceylon, a sudden boom in coconut plantations owed to severe laws in protecting the cinnamon trees in the region. The officials in the Ceylonese settlements of Colombo, Galle and Jaffna received large shares of the taxes from coconut production.

72 Boekhouder-Generaal Batavia, Huygens Institute for the History of the Netherlands (accessed online https://bgb.huygens.knaw.nl/bgb/voyage/7792)

${ }^{73}$ Free burghers (or V rijburgers in Dutch) were the Europeans who lived in the VOC settlements or in the surrounding regions. They were not employed by the Company but conducted trade and managed land as 'free' persons. These
} 
were actively involved in the sale of suri and arrack. ${ }^{74}$ In the years 1751-52, Gillis Bons, a freeburgher, had the contract to provide arrack outside the Fort Cochin area. Other free-burghers involved in this trade were Abraham van Rossum, who provided the beverage to Chettuwa (176167) and George de Aroejo (1755-60), who supplied it to Cranganore and Fort Cochin. For Vypeen Island, the contracts were taken by Diego Perrira, free-burghers Pieter Huwetter and Joseph de Souza in the $1750 \mathrm{~s}$ and $1760 \mathrm{~s} .{ }^{75}$ Earlier, most of the contracts were taken up by indigenous Jewish or Chetty merchants of Cochin. However, with the long Dutch presence, the free burghers diversified their activities. Given the commercial importance of coconut, it was not surprising that coconut trees featured so prominently in Dutch maps of the period. Another commodity which was also crucial in the intra-Asian trade was tobacco.

\section{Tobacco}

Since the seventeenth century, European traders had been keen on purchasing tobacco, which was seen as a highly exotic commodity that could be extensively cultivated. Tobacco cultivation was established in the Deccan by 1605. James Petiver, Fellow of the Royal Society (discussed in Chapter Three) noted that 'Tobacco certainly is a proper native of America, though now it is gott in to the Easte Indies also where (in the province of Guzarat [Gujarat] especially) they sow it in abundance. ${ }^{76}$

By the late seventeenth century, European factories had become involved in the cultivation and sale of tobacco. The Companies were also renting licenses to grow and sell it, along with other mild stimulants or intoxicants, including betelnut and cannabis (Cannabis sativa). An interest in what might be called 'narcobotany' appeared in the collections sent by Samuel Browne to Petiver, which included both these specimens. ${ }^{77}$ Most often historians have looked at the English records to verify the European cultivation of tobacco in Asia. The Dutch Company records in Malabar also point out that the Company was leasing out lands which had tobacco farms. During his tenure of five years, Weyerman confiscated lands that belonged to the rulers of Cranganore and Airur, on the basis that the rulers could not produce enough documents proving their ownership. Once confiscated, these gardens were leased out. One such land agreement surfaces in 1764 for the

\footnotetext{
Europeans were sometimes the earlier servants of the Company who, after the termination of their contract, decided to continue living either in or around the fort. Unlike the half-caste mesticos, they enjoyed a better position in the settlements.

${ }^{74}$ Suri (or toddy is the juice of the palm) and arrack is the spirit made from molasses. Both these drinks are intoxicants. 75 Singh, Fort Cocbin in Kerala, p.160.

${ }^{76}$ Anna Winterbottom, 'Medicine and Botany in Madras, 1680-1720' in Vinita Damodaran, Anna Winterbottom, and Alan Lester, The East India Company and the Natural World (London: Palgrave Macmillan, 2014), p. 55, fn. 67.

77 The English doctor Samuel Brown and botanist James Petiver are discussed in detail in Chapter 3.
} 
cultivation of tobacco farms. ${ }^{78}$ Weyerman also levied excise duties on tobacco in these areas, all of which were north of Cochin, yielding an annual income of fl. 4663 to the Company in $1764 .{ }^{79}$

Tobacco was not just grown in Malabar; it was also imported from neighbouring ports. In 1781, Moens reported that the royal decree enabled the king of Travancore to purchase tobacco from Jaffnapattanam (Ceylon), 'which is the only tobacco the king allows in his country'. ${ }^{80}$ This could be because of the low quality of tobacco produced in Malabar. Further reports indicate that Moens had proposed a plan for the Company to buy all tobacco produced in Jaffnapattanam. This would have forced the Travancore ruler to purchase tobacco from the Company. In doing so, he hoped that the Company could purchase pepper from Travancore in return. Tobacco was thus seen as a commodity that had the potential to be used as a bargaining chip to renegotiate the pepper contracts with regional kingdom. ${ }^{81}$ In Cochin alone, farms of arrack, toddy tapping and rent of the town-inn and tobacco generated 9,390 fanums (1 fanum equals 10 stuivers) in 1741-42. ${ }^{82}$ The Company ensured complete sovereignty over its confiscated lands. In a 1777 report, the chief Interpreter of the Company, Simon van Tongeren, noted that tobacco was seized from a Travancore official inside the Company's territory. The Company accused the ruler of Travancore of violating the Company's sovereignty. ${ }^{83}$

\section{Agrarian policies in the Malabar coast}

There is no evidence in the Company records of any changes introduced by the Company to the farming patterns on its recently acquired land other than the forced cultivation of coconut, spice and fruit-bearing trees like mangoes and bananas. Rather, the Dutch imposed themselves on local rulers' lands as tax farmers. In the Dutch system, property became integral to perceived individual identity and proprietorship could be used to achieve status and recognition. ${ }^{84}$ Dutch law was not imposed on local Christian communities in Malabar but was constantly renegotiated with them. ${ }^{85}$ Consequently, lands continued to be tilled in traditional ways. This made the Company dependent on its cultivators and tenants who were mainly natives, Toepasses, free-burghers and Christians.

\footnotetext{
78 'Leases' dated 1764, Cochin Records: No: 737, TSA, Chennai.

${ }^{79}$ Singh, Fort Cochin in Kerala, p.75.

${ }^{80} \mathrm{MvO}$ Adriaan Moens dated 1781, p.144.

${ }^{81}$ Ibid, p.115.

${ }^{82} \mathrm{MvO}$ of Van Gollenesee dated 1743, p.249.

${ }^{83} \mathrm{MvO}$ Adriaan Moens dated 1781, p.259. Later, the case was dropped as the Company's tenant could not produce evidences of the stolen tobacco from the Company's territory.

${ }^{84}$ Elizabeth Sutton, Capitalism and Cartography in the Dutch Golden Age (London and Chicago: The University of Chicago Press, 2015), p.46

${ }^{85}$ Jos Gommans, 'Continuity and Change in the Indian Ocean' in Jerry H. Bentley, Sanjay Subrahmanyam and Merry E. Weisner-Hanks (eds.), The Construction of a Global World, 1400-1800 CE Part I: Foundations (Cambridge: Cambridge University Press, 2015), p.196.
} 
As discussed in Chapter 2, most of the introduced crops had a clear commercial value for the Company. The Portuguese introduced pineapple and chilli in the sixteenth century to Malabar. Pineapple is also referred to in Volume 11 (dedicated to herbs) of the Hortus Malabaricus, as Kapatsjaka (Ananas comosus L.) as a native crop of Malabar which it was not. ${ }^{86}$ In the wider European trading posts, slaves were sometimes taken along with the crops with the deliberate intention of transplanting the crop and the knowledge of its cultivation. ${ }^{87}$ In some instances, social and botanical experiments went hand-in-hand. For example, in a letter to officials in St. Helena (an English colony) in 1682, the Court of Directors of the English East India Company warned that "it must be your care to see the Seeds Plants \& Negroes so used and employed that...we may at length reap some Benefit of all our Care and Cost." ${ }^{\text {88 }}$

Few recent studies have brought fresh information to bear on the slave trade in Malabar. Dutch historians, Matthias van Rossum and Linda Mbeki, argues that Cochin was one of the main regions of origin for enslaved subjects in the Asian and South African regions under Dutch control. ${ }^{89}$ The slaves transported from Malabar to Ceylon and Cape (1753) by Company employees were mainly from the Pulaya (42\%) and Chego castes (39\%). These were from Dalit castes who worked as servants in the households of landowning families and in agricultural fields. ${ }^{90}$ The people of these castes worked on the lands owned by Brahmins and other landowning classes in Malabar. Itty Achuden, the physician who contributed to medicinal knowledge to the Hortus Malabaricus, belonged to Chego caste, and Van Reede mentions that he had great knowledge of local plants. ${ }^{91}$ When the Portuguese confiscated the lands of the local rulers in the sixteenth century, the cultivators worked for them. With great knowledge of land and its produce, the native cultivators (kudiyan in Malayalam) then worked for the VOC through the intermediaries, mainly of Toepass and Christian communities to whom the lands were leased by the Company.

In 1663, when the Portuguese were ousted from Fort Cochin, the size of the population was 8000 , of which 4000 were Toepasses. ${ }^{92}$ One of the terms of the 1663 treaty signed between the Portuguese and the Dutch was that, 'All free Toepasses (semi-assimilated half castes and Indians) and Canarins (Konkanis) in the Fort shall remain at the disposal and discretion of the

\footnotetext{
86 Van Rheede's Hortus Malabaricus, Vol. 7, pp.1-7.

${ }^{87}$ Anna Winterbottom, 'From Hold to Foredeck: Slave Professions in the Maritime World of the East India Company, c. 1660-1720' in Maria Fusaro and Amélia Polónia (eds.), Maritime History as Global History (Liverpool: Liverpool University Press, 2010), pp.120-21.

${ }^{88}$ Winterbottom, 'From Hold to Foredeck', p. 121.

${ }^{89}$ Linda Mbeki and Matthias van Rossum, 'Private slave trade in the Dutch Indian Ocean world: a study into the networks and backgrounds of the slavers and the enslaved in South Asia and South Africa', Slavery and Abolition, Vol. 38, no. 1, 2017, p. 97.

${ }^{90}$ Mbeki and van Rossum, 'Private slave trade', p.110.

91 Van Rheede's Hortus Malabaricus, Vol. 7.

92 Pius Malekandathil, Portuguese Cochin and the Maritime Trade of India 1500-1663 (Delhi: Manohar, 2001), pp. 77- 78.
} 
(Dutch) general. ${ }^{93}$ These communities acted as mediators between the Dutch and the native rulers. They could be termed as the 'go-betweens' in the Dutch-Malabar trade. ${ }^{94}$ Sanjay Subrahmanyam argues that these 'go-betweens' existed during transactions, but these transactions had to be of a certain type and were characterised by a form of friction..$^{95}$ In Malabar, the Toepasses, lascars ${ }^{96}$ and Christians worked as interpreters, translators, cultivators, artisans and soldiers. ${ }^{97}$ In 1717 , when the Company attacked the Calicut ruler's army, there were around 193 Toepasses and 113 lascars in the service of the Company. In his memoir, Moens mentions around 450 Toepasses living in Cochin in 1780. Subrahmanyam argues that the go-betweens are born of the friction in a transaction. They are often the third party in a transaction where the two other parties-who are individuals or larger entities-are incapable of completing the transaction in the absence of mediation. ${ }^{98}$ As Subrahmanyam argued, they also acted as negotiators in times of tensions. In 1743, the Company sent Jewish merchant Ezekiel Rahabi and Toepass Silvester Mendes to negotiate a peace treaty with the envoys of Travancore. The Commander praised 'their skill in handling a difficult situation and expressed his satisfaction' after the peace negotiations were a success. ${ }^{99}$ Here, the idea of an interlocutor is significant as the Company had to choose the group or groups which would represent them in a dialogue with the Malabar elite at the risk of going astray. Their mixed race also made the Toepasses subjects of suspicion by the Dutch Commanders, who thought they still owed allegiance to Portugal. Commander Moens commented on the Toepasses rather disapprovingly:

the majority of them live scattered over the country...they are a ridiculous lot, on the one hand full of Portuguese pride, but on the other hand in time of danger they would, like the meanest Malabari, put up with their privations in a field or forest only not to expose

\footnotetext{
93 Treaty 1663, Central Records, Ref. No. T. 90 (non-paginated), KSA, Ernakulam.

94 These communities need a separate examination as there are limited studies that have so far looked at the role these communities played in the eighteenth century.

${ }^{95}$ Sanjay Subrahmanyam, 'Between a Rock and a Hard Place: Some Afterthoughts' in Kapil Raj, Simon Schaffer, Lissa Roberts and James Delbourgo (eds.) The Brokered World Go-Betweens and Global Intelligence, 1770-1820 (Sagamore Beach: Science History Publications, 2009), p.430. Subrahmanyam argues that the go-betweens are born of the friction in a transaction. They are often the third party in a transaction where the two other parties-who are individuals or larger entities-are incapable of completing the transaction in the absence of mediation.

${ }^{96}$ Lascorijns or Lascars (in English) were persons of indigenous origin who served in the army of the European Companies. The term was used by the Portuguese to distinguish them from the Toepasses or semi-assimilated native Christians. The Malabar Gazetteer of 1908 describes them as descendants of Pulayan converts of Malabar. Some of them were also brought from Ceylon when the Dutch ousted the Portuguese in Cranganore in 1663. The term lascars are also used for Lascars were also sailors in European ships.

${ }^{97} \mathrm{MvO}$ Moens dated 1781, p.188.

${ }^{98}$ Subrahmanyam, 'Between a Rock and Hard Place', p. 430.

${ }^{99}$ Ibid, p.193.
} 
themselves to danger. I know from experience how much trouble I had in the beginning to get them through a military course once annually. ${ }^{100}$

Thus, the mistrust and the mediation between the Dutch and the Toepass communities make a strong case of the need to analyse the roles played by such communities in the production of knowledge in different regions. Sometimes, imperial power was ruptured by a dependence on the strong mercantile communities in South Asia like the Toepasses, Canarins and Konkanis who took on roles as interpreters or sometimes treaty negotiators. Thus knowledge was mediated, communicated and sometimes controlled by communities (to the best of their abilities), through their attendant religious, political and educational institutions. ${ }^{101}$

In the eighteenth century, the role of the Company in Malabar was in fact only to raise rent from its lands. The Dutch confiscated and used land for generating income and exploited the soil for cash crops. The Company revenue assessments in the leases were often unrealistic to achieve. The cultivation was dependent on the monsoon yet the Company wanted to raise a consistent revenue from the region. Commander Moens advised his successor Gerard Van Angelbeck to adopt strict measures when it came to abatement requests from leaseholders. He wrote that

the renters now and then apply for an abatement on the plea of an unprofitable year, or sometimes because some trees have been blown down, or on the ground that the crop on the field has been destroyed and eaten up by wild animals and cattle. You must refuse point-blank once for all. ${ }^{102}$

The only time the Company could be responsible for a crop failure was when 'we had of necessity to cut down trees and level the ground' for Company troops, forts or buildings. ${ }^{103}$ For example, Moens ordered landholders to 'cut out all the trees and shrubs and demolish various buildings' on the island of Vypeen (also written as Baypin in Dutch records), because the Company wanted 'a clear view to the other side of the river and a proper open plain'. ${ }^{104}$

\footnotetext{
100 Ibid, p.189.

${ }^{101}$ Kapil Raj makes a similar argument in the context of British conquest and merchant communities in South Asia. See, Kapil Raj, 'Networks of knowledge, or spaces of circulation? The birth of British cartography in colonial south Asia in the late eighteenth century', Global Intellectual History, Vol. 2, no. 1, 2017, p. 53.

$102 \mathrm{MvO}$ Adriaan Moens dated 1781, p.227.

103 Ibid.

${ }^{104} \mathrm{Ibid}, \mathrm{p} .204$. The island of Vypeen was strategically located across the river in Cochin, so if the army of the ruler of Calicut proceeded to attack the Fort, Vypeen would be a strategic location to spy. The Company had earlier stationed troops at Vypeen to attack the Portuguese in 1663.
} 
As for the disposal of lands, the Dutch required land auctions to be announced in public, along with a description of the land on sale. ${ }^{105}$ Officials prohibited the sub-leasing of land but relaxed these rules for Christian subjects of the Company. For instance, in the 1756 lease agreement of St. Jago island, south of Cochin, it was written that the 'tenant is only allowed to sublet the lease to Christian subjects of the Company and dwelling on the land will be permitted provided given due notice in advance. ${ }^{106}$

The Company kept detailed records of the exact measurement of the size of the plots that it had confiscated or received from the Portuguese. In most cases, the Company required guarantors for leases (see Appendix V). For instance, in 1756, St. Jago was leased to Toepass Amaro de Souza for a rent of 25,000 Cochin fanums. The lease was signed in Cochin, with two Christians, Choelikel Mingo and Brahalikel Kitto, as guarantors. ${ }^{107}$ Company tenants mainly consisted of members of the Toepass community, Dutch free-burghers, lascars and Konkani merchants. The members of these communities had a longstanding knowledge of the land. Records indicate the names of Dutch free-burghers Joost Verhulst and Fillip Cardozo as guarantors for certain lease contracts. In other cases, free-burgher Jan Jurriensz acted as a guarantor for lease contracts. ${ }^{108}$ This could be either because the Company trusted the Dutch freeburghers as legal guarantors rather than the Toepass and local cultivators, or it was because they could speak the language and guarantee the terms of lease.

The cost of the land was paid by the tenants as taxes ('s heerengeld) fixed by the Company. The tenant also had to bear the costs of maintenance of any dikes or dams to regulate water supply and the maintenance of fences (vrijgeld). The sterility of the land was not taken into account; the focus was on the volume of production. This was in conjunction with the Roman Dutch Law that was practised in Holland. ${ }^{109}$ In most cases, orders were given regarding the permitted cultivable crops in the land. ${ }^{110}$ In a land lease agreement of 1766 signed between Commander Cornelius Breekpot and Lascar Thoma for a garden in Cheramangalam, the leasees were instructed not to

\footnotetext{
105 Schoenmakers, Landpachten in Holland, p.26.

106 'De huurder sal gene andere pagters mogen hebben, nog toelaten dan die Christenen onderdanen van d'E. Comp[agnie] en op dat land woonagtig zijn, mits daarvan geven behoorlijke voorkennisse' Conditions of Lease $1^{\text {ST }}$ January 1756 to $31^{\text {st }}$ December 1765, Cochin Records: No. 600, pp.8323-8324. For the other clauses of the land lease, see Appendix V.

107 According to Moen's report in 1781, the island contained 3,116 fruit-bearing coconut and other trees and 48 parras of cultivated land (See appendix V).

108 Singh, Fort Cochin in Kerala, p.160.

109 Marleen H. J. Horst, Compensation for Improvements: The Roman Dutch Law in Sri Lanka (Amsterdam: Free University Press, 1989), p.109.

110 Schoenmakers, Landpachten in Holland, pp. 27-30.
} 
grow wild cinnamon. Instead, the tenant was encouraged to grow pepper and ginger. ${ }^{111}$ Most often, Company officials in the settlements had no prior knowledge of the region. They lacked any understanding of cropping patterns, seasons, harvest times and soil fertility. In his memoir, Moens wrote, 'I who had neither special knowledge nor local knowledge of Malabar but had already heard in Ceylon of the fraud in the commercial books in the coast. ${ }^{112}$ By the time they became acquainted with the region, their tenure would end, and the next Commander would take charge.

The transition in the ownership of land from the Dutch to the English did not improve the conditions of cultivators and land in Malabar. In 1795 when ownership was handed over to the English East India Company, revenue extraction remained the main focus and it continued in a more efficient and ruthless manner. By the end of the eighteenth century, the drive to increase revenue and the English Company's and its servants' ambition of building private fortunes led to continued land exploitation, both through territorial expansion and intensification. ${ }^{113}$ In contrast to the practice of the VOC, the English commissioned detailed surveys in Malabar in the beginning of the nineteenth century. These surveys focused on the commercial viability of crops, cropping patterns, soil types, facilitating intensive extraction of revenue. For instance, in 1807 Scottish physician Francis Buchanan, who surveyed Malabar for the English East India Company wrote that

a plantation is made, in which coco-nut trees are placed at 40 Adies, or lengths of the foot, from each other, three Betel-nut palms may be set-between every pair. If we take 40 Adies at 36 feet, an acre would plant 33 coco-nut, and 100 Betel-nut palms, and leave interstices for Mango and Jack trees, on which the pepper vine may be raised: but in Malabar such economy of ground is seldom observed. The Betel-nut palm begins to bear in from eight to ten years, and in twelve or thirteen arrives at perfection. ${ }^{114}$

Richard Grove has argued that when Van Reede assessed land in the Company's Cape settlement in April 1685, he began what Grove calls, 'the first step in the centralised policy of state

\footnotetext{
${ }^{111}$ List of the farms, gardens and fields, Cochin Records, No. 696, The lease agreement signed by Thoma was for a period from $20^{\text {th }}$ January 1766 to 1780 for a price of 400 Cochin fanums annually. The agreement states that the garden consists of 70 coconut of which 69 were fruit bearing trees, 20 arrack trees and 1 mango tree.

$112 \mathrm{MvO}$ of Adriaan Moens dated 1781, p.239.

113 See Irfan Habib, 'The eighteenth century in Indian economic history', in P. J. Marshall (ed.), The Eighteenth Century in Indian History (Cambridge: Cambridge University Press, 1997), p. 111. Also argued by Vinita Damodaran in the case of eighteenth century Bengal, see 'The East India Company, Famine and Ecological Conditions in Eighteenth-Century Bengal' in Vinita Damodaran, Anna Winterbottom and Alan Lester (eds.), The East India Company and the Natural World (London: Palgrave Macmillan, 2015), pp.82-83.

${ }^{114}$ Francis Buchanan, A Journey from Madras through the countries of Mysore, Canara and Malabar. Vol 2. Asian Educational Services (facsimile) (London: T. Cadell and W. Davies, 1988), p.505.
} 
conservationism'. ${ }^{115}$ Grove suggested that the European Company officials saw conservation as a means of improvement by ensuring the long-term viability of a resource. The way to extract revenues from the agricultural land remained, as elsewhere, a complex process of renegotiation among various interests, from crown officials to land tenants. The difficulty in controlling the land and its production, and commerce and labour in Asia was due to these complex socio-economic arrangements and political organization that were already in place. As Kapil Raj argues, knowledgeproduction was an object of negotiation and mediation in spaces that were complex and not clearly delineated. ${ }^{116}$ Such negotiations did not undermine European knowledge-systems but rather strengthened them. For instance, in Adriaan Moens's Memorandum (dated 1781), he divided the contents on the VOC administration of Malabar into political, social, religious categories such as Payencheri Nairs, Heathens, Christians and henceforth (see fig. 29). ${ }^{117}$ This classification, based on the political categories of the VOC's imperial interests in Malabar, were the initial steps on which the later colonial state-building practices rested. These memorandums could be arguably the first steps towards classifying the lands and people into European Orientalist frameworks. This chapter argues that the cognitive exercise of socially organizing a diverse settlement was an important form of knowledge-making.

\footnotetext{
115 See for example, Richard Grove, Green Imperialism: Colonial Expansion, Tropical Island Edens and the Origins of Environmentalism, 1600-1860 (Cambridge: Cambridge University Press, 1995), p.140.

116 Kapil Raj, 'Networks of knowledge, or spaces of circulation? The birth of British cartography in colonial south Asia in the late eighteenth century', Global Intellectual History, vol. 2, no. 1, 2017, pp.52-53.

${ }^{117}$ Family Archives of Adriaan Moens, Inventory number 14, National Archives, The Hague.
} 


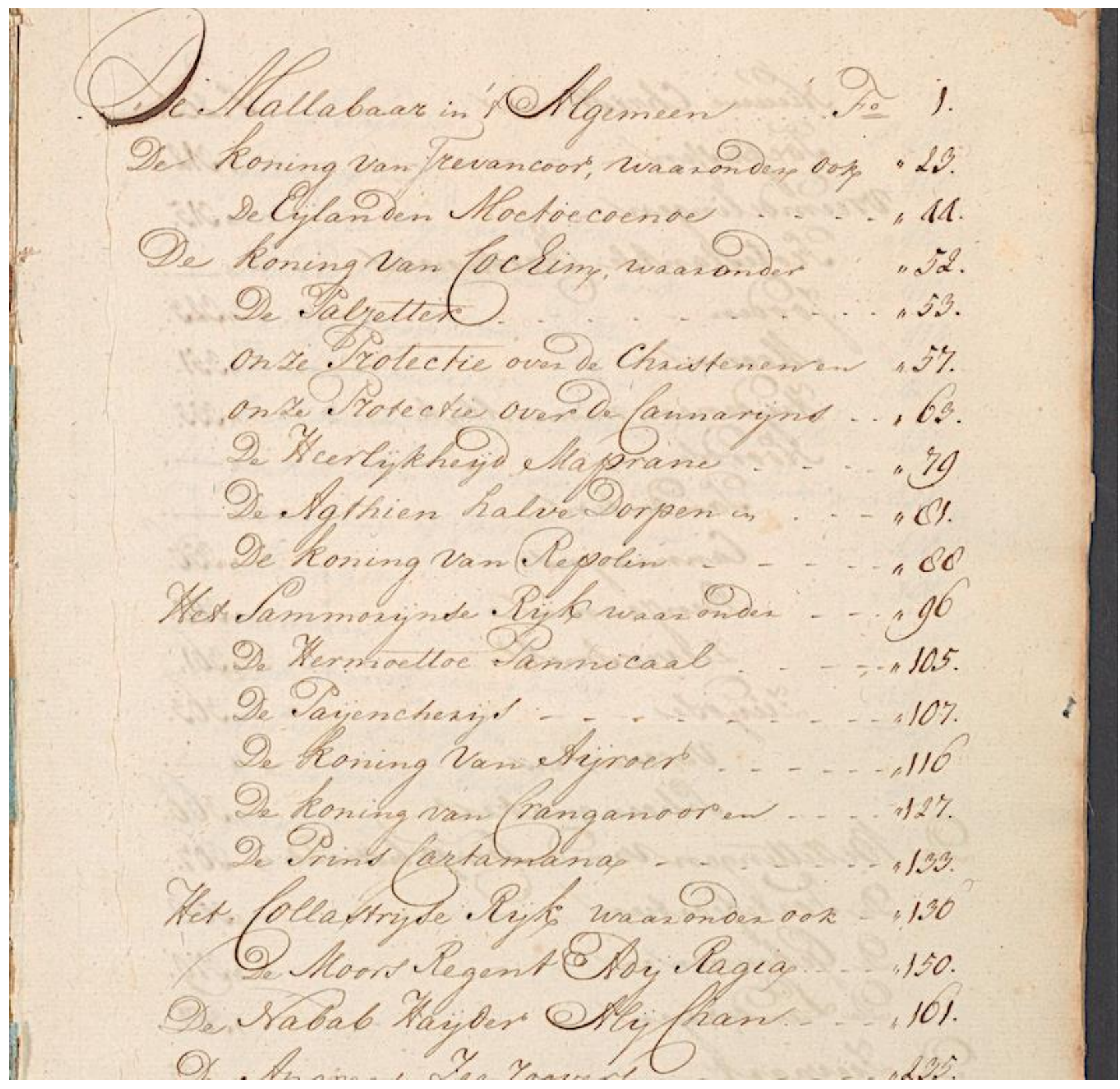

Fig. 29. A page from Adriaan Moens's Memorandum, 1781. (Courtesy: National Archives, The Hague) 
As for the development of agriculture in Malabar, it is rather surprising that Van Reede's successors did not have an understanding of the information in the Hortus Malabaricus. Given the work was celebrated in the Republic and in botanical correspondence in Europe, the practicability of this knowledge was never put into use by the Company in Malabar. Unlike other medicobotanical works of the period, the Hortus Malabaricus details the location and the environment in which certain crops and plants grew. Yet, the Commanders did not use it as a reference while leasing out lands for the cultivation of coconut or arrack. There are no references to the Hortus Malabaricus in Malabar company correspondence or official archives. Van Gollenesse, who took charge of the Company settlements in Malabar in 1735, mentioned that he had read Van Reede's memoir that he had left for his successor Jacob Lobs. However, Van Reede's memoir does not refer to the Hortus Malabaricus which could have been a manual for the management of land of Malabar. With the Hortus Malabaricus, Van Reede was creating a work of botany that would bring him recognition and status in the Republic and in the administration of the VOC.

\section{Conclusion}

Historians have identified a process of regionalization in the eighteenth century in which coastal polities became more powerful than interior rulers. The Dutch did not benefit from this, unlike the English East India Company. It was not the only problem that the Company faced in the Indies that led into crisis; there was also the turbulence of the eighteenth-century Republic. The developments in Europe placed fiscal pressure on its outposts.

The income from the land in the Company's settlements such as the Cape and Malabar, could have made up for the losses incurred in trading activities. However, the differences of opinion among various Commanders, coupled with government hesitation to introduce 'nontrade' policies, created difficulties in maintaining overseas settlements. This study of Company activities in Malabar indicates that the Company generated income even after 1740 through nontrade activities, such as land revenues, excises and tolls. Nevertheless, the Company administration could not generate enough income needed to invest in lands in the eighteenth century. Even if it did, the Company would have had to depend on local cultivators, go-betweens and native rulers.

A compounding problem was that the Directors and Government in the Indies operated at a distance and often lacked an understanding of conditions on the ground. This created differences between those who lived in the settlements and managed the settlements from afar. Ever since the Company failed to secure the pepper monopoly, Malabar was seen as a less 
profitable settlement in Asia, bearing a financial burden on the Company in Asia. This also brings forth the lack of understanding of the Company administration in Amsterdam regarding non-trade matters. From a distance, the Board of Directors would only set out rules and regulations for controlling trade in Asia. They did not invest in landed property in Malabar. The officials working in the settlements did not possess native agricultural knowledge. They could only depend on gobetweens in hoping to grow the crops the Company wanted. This indicates that knowledge could only be used for imperial control when it could be translated into practice. In conclusion, the VOC's land management shows that there was a large gap between the production of knowledge and the manifestation of knowledge in the Company settlements. The two processes of scientific knowledge-production and imperial administration often proceeded in parallel, without necessarily overlapping. Scientific knowledge-production was motivated by intellectual developments in Europe, rather than by the imperatives of the empires. 


\section{CONCLUSION}

This thesis began with the aim of examining the knowledge-making endeavours of the Dutch East India Company in Malabar from 1663 to 1795, i.e. from the successful take-over of the Fort Cochin from the Portuguese to handing over the Fort to the English East India Company. As examined in the chapters of this thesis, botanical and cartographical knowledge-making occurred through the official and unofficial efforts of various VOC officials and local peoples with whom they came in contact in Malabar. The partial diffusion of local medicinal knowledge into European classificatory systems through the multi-volume Hortus Malabaricus and the application of European cartographic concepts to visually represent the Malabar landscape indicate how knowledge-making was a complex, multi-layered process and how, with travel and translation, knowledge-making was also a continuous process.

Through the networks of the VOC trade, the thesis has examined how knowledge-making in Malabar contributed to the development of observational and experimental sciences in Europe on the one hand and the development of imperial projections and control in Malabar on the other hand. It perhaps is the dilemma of the intellectual historian to find the impact of ideas on the actions of the historical figures of her research. Using the concept of boundary objects, borrowed from Susan Leigh Star and James R. Griesemer, this thesis examines the movement of knowledge and physical objects along with people from various socio-political groups with specific expertise. ${ }^{1}$ In showing the movement of objects, the thesis examines the cultural practices surrounding knowledge-making in Malabar and the Dutch Republic.

While Commander Hendrik Adriaan Van Reede, the compiler of the Hortus Malabaricus succeeded in deploying a polyglot, interdisciplinary team, the VOC failed, unlike the English East India Company, to use the information that team ultimately produced for imperial control. Thus, the theory of boundary objects has facilitated a multi-faceted discussion of early modern knowledge-production, but, as a model, it falls short in identifying and describing the variants in inter-group politics and varying degrees of patronage. In this respect, the thesis has highlighted both the potential and limitations of Dutch knowledge-making, as well as its imperial ambitions. If knowledge-making is taken as an activity that leads to an increased understanding of natural history, then this activity was not the official focus of the Company. As Alette Fleisher argued, the

\footnotetext{
${ }^{1}$ Susan Leigh Star and James R. Griesemer, 'Institutional Ecology, 'Translations' and Boundary Objects: Amateurs and Professionals in Berkeley's Museum of Vertebrate Zoology, 1907-39', Social Studies of Science, Vol. 19, no. 3, Aug. 1989, pp.389-390.
} 
VOC employees engaged in knowledge-making only as part of their trade activities. ${ }^{2}$ If so, the thesis asks: what were these activities in which they engaged, and what knowledge did they produce of Malabar?

As discussed in Chapter One, the initial impetus for the commercial endeavours of the VOC centred on pepper trade. Trading companies in the Republic sought to make huge fortunes from the buying and selling of this spice in the seventeenth century. The search for black gold brought the VOC ships to Malabar and to other trading centres in Asia. Malabar had long-standing trade relations with other foreign merchants, and the Portuguese were the first among the European trading companies in Malabar. The beginning of the European trade in Asia sparked the movement of goods on a large scale between Europe and Asia, and across Asia by sea. This movement of goods was driven by a movement of peoples and ideas. Encounters between different cultures generated knowledge-making, as expressed in paintings, travel literature and natural history collections. To pursue the question of natural historical knowledge-production, two themes were taken up for examination in the subsequent chapters-botany and cartography.

\section{Hortus Malabaricus and the question of 'Indigenous Knowledge'}

The theme of knowledge-making was examined by focussing on the production of the Hortus Malabaricus (1678-1693) in Malabar under Van Reede (Chapter Two). By examining the numerous people who were involved in the production of the manuscript in Malabar, Batavia and the Dutch Republic, the chapter argued that the Hortus Malabaricus was a prime example of how early European bioprospecting worked. The search for effective pharmacopoeia alongside the potential fortune from selling medicinal plants in the Republic, engaged many people in the activities concerning natural history. Collecting was pursued as an elite activity in the seventeenth-century Dutch Republic, and practised by merchants, apothecaries, surgeons, burgomasters, missionaries and the VOC officials in the Indies (Chapter One). The Hortus Malabaricus illustrates the process of botanical knowledge-making across the VOC settlements and the Republic. Initiated by Van Reede in Malabar, the process involved gathering medicinal and botanical information about the local flora and relied on the expertise of local collectors and medicinal practitioners. By taking inspiration from the rich wealth of scholarship produced on early modern scientific endeavours in Europe, the case study of Malabar indicates how knowledge-making took place not only in the

\footnotetext{
2 Alette Fleischer, 'The Company's Garden and the (Ex)change of Nature and Knowledge at Cape of Good Hope (1652-1700)' in Lissa Roberts (ed.) Centres and Cycles of Accumulation in and around the Netherlands (Muenster: LIT Verlag, 2011), p.104.
} 
European metropole but also in the VOC settlements of Malabar and Batavia. In examining knowledge-production, the thesis has problematized the concept of the native informant (Chapter Two) by examining the different epistemes they brought to the production of the work. ${ }^{3}$ The role of Van Reede was to transport the knowledge of Malabar's natural history to European scientific institutions. Van Reede's position as a VOC commander in Malabar, stationed at Cochin (the administrative centre of the VOC), gave him access to the networks of local surgeons, as well as the court of the ruler of Cochin and inland Malabar. His political authority in Malabar gave him the power to organise a group of people to work on a scientific project of his choice. His directions established a local system in Malabar in which diverse allies (Brahmin and Ezhava medical practitioners, local plant collectors, Portuguese priest) could participate concurrently in the heterogenous endeavour of producing a scientific work. What Van Reede wanted at a local level was the accurate information of carefully illustrated plants that could be transported to the Republic.

While Van Reede did the laborious task of organizing the production of Hortus Malabaricus in Malabar, he lost control of its print form as the work was reworked in the scholarly environs of the Republic. Here, Van Reede acted as an able administrator and not a scholar, medical practitioner or botanist. For translating and creating the print form of the multivolume book, Van Reede sought patronage from the elites of the Republic. Would that mean that the transfer of medico-botanical knowledge from Malabar to the Republic was only a work of translation? It was more than that. The demand for new knowledge about Asian flora established patronage networks connecting myriad different people. Those in the Republic who were engaged in the production of the print form such as university professors (Arnold Syen, Abraham Poot and Joannes Munnicks) and commentators ( such as Jan Commelin), used their position as 'learned men' to legitimise their claim over the nature of Malabar and its representation in the Hortus Malabaricus. They presented to Europe an ordered scientific work divided into volumes on the diverse and expansive environment of Malabar. By transforming the initial field notes and pen and ink drawings into scientific language with descriptions, etchings and maps, the networks in the Republic claimed a share in the botanical knowledge of Malabar.

By following the political careers of Van Reede, Jan Commelin and Joan van Huydecoper, the thesis examined how power and patronage worked in knowledge-production. The privileged positions of Commelin and Huydecoper as the co-directors of the Amsterdam Botanical Garden (established 1682) gave them a certain degree of autonomy and placed their contributions at the

\footnotetext{
${ }^{3}$ Kapil Raj, 'Thinking Without the Scientific Revolution: Global Interactions and the Construction of Knowledge', Journal of Early Modern History, Vol. 21, 2017, p. 455.
} 
centre of the emerging city of Amsterdam. The city had been fashioned as a centre of commerce and knowledge as visualized in Visscher's profile of Amsterdam (Chapter One). By raising the importance of the botanical garden in the city and expanding their plant collections to include rare and exotic plants from Asia, Africa and America, the development of botany was examined as a backdrop to explaining the increasing interest in knowledge about plants, including from Malabar. The VOC trade played a significant role in this travel of plant specimens from far-flung regions to the commercial hub of Amsterdam.

\section{Fashioning as the metropolitan savant}

An engagement in natural history was not only an act resembling the humanist ideas and Baconian impetus for the study of nature, but it was also what a savant or someone who sought to be one pursued in the Republic. The fortunes of the seventeenth century created a society that valued naturalia. The wealth enabled the Dutch to possess natural history collections, private gardens and trade in medicines. As mentioned in Chapter One, the value of commodities like plants was different from items such as gold and silver. Knowledge of plants and the possession of rare foreign plants indicated social capital. For recognition as a scholar in a society that valued knowledge, as Catherine Abou-Nemeh indicated, 'knowing' became equated with the status enjoyed in society. ${ }^{4}$ As discussed in Chapter Three, Van Reede and Commelin tried to further their status in the Republic by fashioning themselves as metropolitan savants through personal acts of knowledge-making. While Van Reede adopted the title of nobility, Commelin commissioned a portrait of himself surrounded by plant drawings and a bust of Theophrastus, the Father of Botany. As a scholar, Commelin published works such as the Hortus Medicus Amstelodamensis modelled on the Hortus Malabaricus. The botanical illustrations developed from a pursuit of nature. From pencil drawings to watercolour pictures, catalogues such as Monickx Atlas (1686) were published to visually represent the glory of the plant wealth of Amsterdam. On the other hand, Joan Huydecoper utilised his position as one of the VOC Directors to engage in the trade of plants for the Amsterdam Garden as well as his private collection. Having a huge collection of rare and exotic collectibles raised one's social status and brought reputation in the Republic. Other naturalists of the period, such as Maria Sybilla Merian, used the Hortus Malabaricus as a reference work when describing foreign plants in her work. The establishment of the Royal Society of London that actively pursued scientific endeavours also facilitated the domestication of plants featured in the

\footnotetext{
${ }^{4}$ Catherine S. Abou-Nemeh, 'The Natural Philosopher and the Microscope: Nicolas Hartsoeker Unravels Nature's “Admirable CEconomy", History of Science, Vol. 51 no. 1, 2013, p.3.
} 
Hortus Malabaricus in Europe, far away from where the plants actually grew. So, what did the production and diffusion of indigenous knowledge in the Hortus Malabaricus result in?

I argue here that the production and diffusion of indigenous knowledge in the Hortus Malabaricus led to at least three forms of intellectual networks of knowledge-making. Firstly, in Malabar, it relied on a team of physicians, translators, draughtsmen and artists at the local level in the backdrop of the VOC trade. This local network was organised by Van Reede whose political power gave him an upper hand in deciding the 'crafting, diplomacy, the choice of clientele and personnel' involved in the compilation. ${ }^{5}$ Secondly, Van Reede's efforts brought together an intellectual network of Dutch physicians, amateurs, artists, editors and commentators who worked on a single focus of scientific study for the advancement of knowledge in the Republic. The people engaged in this network in the Netherlands translated local knowledge to scientific formats by reducing the local specificities to European accepted scientific categories. Thirdly, subsequently, the scholars attached to the English East India Company and the Royal Society of London used the Hortus Malabaricus in their own bioprospecting efforts in the eighteenth century, such as illustrated in the correspondence discussed of Fellow James Petiver and his counterpart in Malabar, surgeon Samuel Brown (Chapter Three). The third network mainly manifested the knowledge of Malabar flora prepared by the first two networks for their own understanding of the region. Thus, people spread across Malabar, Batavia, and the Republic engaged in the production of the Hortus Malabaricus in different capacities and at different times. With or without visiting Malabar, they claimed knowledge about Malabar. This diffusion of the knowledge of the natural history of Malabar in Europe indicates how science made local knowledge global. What does this say about the VOC as a trading enterprise?

The VOC served as the apparatus that was used for the production of knowledge. The movement of knowledge in the Hortus Malabaricus through these intellectual networks was made possible only via VOC trade. The infrastructure of the VOC, such as its intra-Asian shipping networks, facilitated the movement of material objects such as the manuscript form of the Hortus Malabaricus from Malabar to Batavia and from there to the Netherlands. The value of the Hortus Malabaricus could only be realized because it was brought to a region where such botanical knowledge, presented in this particular format, was in demand. But the VOC administration did not support Van Reede's botanical expeditions in Malabar, which spoiled Van Reede's ambitions for himself and his adopted settlement, Malabar. Van Reede could neither make Malabar the garden that the VOC wanted to invest in nor could he further his own investigations there. Though his position as a VOC employee brought him to Malabar, his employment with the Company came

\footnotetext{
5 Star and Griesemer, 'Institutional Ecology, 'Translations' and Boundary Objects', p.398-399.
} 
at a cost. Van Reede failed to secure VOC patronage for Malabar nor could he negotiate with the seniors to gain ascendency over rivals such as Van Goens, stationed in Ceylon. Van Reede's ambitions to prepare a work on the Cape flora indicates that he was a liefhebber of nature and botany. Van Reede was constantly on the move to VOC settlements at the order of the GovernorGeneral. So, the pressure of being a VOC employee hindered his pursuits of botanical interests as well as the extent to which he could mobilise patronage in support of his botanical pursuits. As a commercial enterprise that pursued financial gains, the promotion of works on natural history was not attractive to the Company as it could not bring immediate material benefits. Considering this observation, this thesis departs from Harold Cook's analysis that Company commercial interests ran parallel to empirical interests. ${ }^{6}$ Rather, as this thesis shows, the Company was only willing to patronise certain aspects of empirical study. While the VOC did not actively endorse Van Reede's botanical and scientific endeavours, it did take pride in its visualisation of territorial power.

\section{Picturing Power}

Map-making or cartographical endeavours underpinned the VOC use of images in Malabar in the eighteenth century and readily demonstrated the usefulness of practical knowledge-making (Chapter Four). In this case there was a reverse journey of ideas, as cartographic methods and concepts travelled from Europe to Malabar, they subordinated local knowledge makers. A key theme examined here was how the Dutch knowledge-making activities in Malabar were an extension of the Portuguese endeavours. Initial VOC maps, plans and topographical charts relied on Portuguese models of the Malabar settlements. The two centuries of Portuguese presence on the coast reflected the way in which the Dutch saw Malabar. From acquiring the Portuguese forts, churches, hospitals and lands, the Dutch continued the Portuguese model of management at least for the most part of the seventeenth century. In taking over the Portuguese settlements with their Christian population that lived inside the forts, the Dutch were able to tap a population that would also play a key role as 'go-betweens' in their knowledge-making endeavours.

The map-making and the visual representations of the VOC power indicate three stages of the knowledge-making process: initially, the transformation of Portuguese imprints in Malabar, then, in the eighteenth century, the mapping of maritime trade routes and glorification of VOC naval supremacy and its territorial ambitions. The third stage can be understood by the detailed maps of inland Malabar demarcating VOC possessions and the process of fashioning the Company as a major sovereign power. By drawing the political boundaries lines in bold colours, while

\footnotetext{
${ }^{6}$ Harold Cook, Matters of Exchange: Commerce, Medicine and Science in the Dutch Golden Age (New Haven and London: Yale University Press, 2007), p.304.
} 
traditionally such borders between local kingdoms were always fuzzy, the VOC maps created a new 'geo-body' for Malabar. These visual representations also allow us to see the political silences in the maps, such as the lack of representation of the English fort. The maps produced on regions with unresolved claims to property indicate the pictorial ways of appropriating territory. For instance, the territorial claim to the rice-producing lands of Pappinivattom with certain territorial claim were depicted as Compagnie Landen. The delay in correspondence between the Directors and the officials often resulted in local VOC officials deciding on local matters. One such example is the transfer of ownership of the Company Gardens in Pappinivattom to the ruler of Cochin in 1769 without detailing the reasons to the Governor General in Batavia (noted by Adrian Moens in his Memorandum discussed in Chapter Four).

The diverse landscapes and spaces of the different ruling kingdoms in Malabar were visually translated for the purpose of taxation and for making land a saleable commodity. Local knowledge was thus transformed into visual representations of the Company's imperial aspirations for profit and sovereignty. Chapter Four also brought out the contradictions of the economic conditions of the VOC in Malabar that struggled to upkeep the fortifications and fund military campaigns. Thus, the VOC aimed to expand its presence in Malabar yet struggled to maintain what it owned.

\section{Surveys as a knowledge-making activity}

Though the VOC Directors and the Governor-General in Batavia felt that Malabar was a less profitable settlement than other settlements, Malabar officials transformed the VOC's role from a merchant-warrior to a landlord. After the 1750s, the VOC's revenue from Malabar grew mainly because of the profits from land revenue, excises and tolls. The Company depended on the native cultivators and Toepass community as leasees. By examining the presence of Toepass community, this thesis argues that they played a key role in producing knowledge about Malabar. As a group that has not received scholarly attention in the early modern South Indian historiography, this thesis highlights their role as translators, tenants, traders, diplomats and soldiers. By focusing on their acts of mediation, the thesis examines the idea of power and the cultural appropriation in the production of knowledge.

By focussing on the coconut and tobacco trade, two key commodities in the Company's intra-Asian trade, the thesis examines how the cultivation of cash crops was vital for sustaining the Company's revenue. Once the Company started to be actively engaged in the buying and leasing of lands in Malabar, surveys were undertaken to inspect the conditions of the VOC in Malabar. 
This thesis argues that maps, plans and proposals for fortifications and eventually surveys undertaken by the VOC in Malabar were a form of knowledge-making. How? Through maps and surveys, the VOC sought to classify peoples and their habitats into social, political and religious categories for the purposes of governance. The VOC's activities in eighteenth-century Malabar indicate the ways in which the natural resources of the region were ordered and how the lands were divided across the kingdoms. Here, knowledge-making could be seen as appropriation of indigenous knowledge. Such knowledge would be useful not for the local people who provided the information, but for the purposes of governance, a prime example of which was the organised land management by the English East India Company in the eighteenth-century Malabar.

William Jones, the famous English Orientalist who wrote extensively on India, quotes Van Reede's Hortus Malabaricus for his botanical writings in Bengal, Botanical Observations on Select Indian Plants. $^{7}$ Another English official, Francis Buchanan trained in Scottish natural history (appointed to survey Malabar in 1807, as discussed in Chapter Five), possessed copies of the Hortus Malabaricus and wrote commentaries on the same for the Linnaean Society. Once in London, Buchanan wrote to his friend Edward Smith (in 1819), 'what appears to me most likely to be useful to science would be to publish a Commentary on the Hortus Malabaricus and Flora Amboinensis'. ${ }^{8}$ Such examples indicate how, in the nineteenth century, English surveyors and botanists used the Hortus Malabaricus for gaining knowledge of the crops, land and taxes in Malabar, a practice that was not undertaken by the VOC officials in Malabar. As shown in Chapter Five, the VOC officials did not use the Hortus Malabaricus for understanding the cropping patterns or cultivation of cash crops. This was partly because the Hortus Malabaricus was not endorsed as a potential manual for the commercial interests of the Company. It remained a magnum opus and not a practical guide during the VOC period in Malabar.

The economic and political conditions of the VOC on the Malabar Coast after the 1750s were not hopeful. The Dutch Commanders Casparus de Jong and Godefridus Weyerman tried to increase the profit of the settlement by bringing in more taxable lands and engaging in the sale of arrack and tobacco. The revenue books from the Malabar Coast indicate profits in 1750-55 and 1770-75, but insufficient to outweigh the dwindling profits from the spice trade and to maintain the settlements. Also, as discussed in Chapter Four, the conditions of the VOC establishments, such as forts and garrisons, were not satisfactory. Though the surveyors and engineers made proposals for the reduction and strengthening of VOC forts, especially, Fort Cochin, there were

\footnotetext{
7 William Jones, The Works of Sir William Jones in Thirteen Volumes, Vol. II (London: John Stockdale, 1807). See pp. 76, 102, 108

${ }^{8}$ D. J Mabberley and Francis Hamilton, 'Francis Hamilton's Commentaries with Particular Reference to Melianceae', Taxon, Vol. 26, No. 5/6, Nov. 1977, p. 525.
} 
no funds allocated from Amsterdam or Batavia for this purpose. The English East India Company had established itself at Fort Anjengo (1696) and posed a significant threat to the VOC on the Malabar Coast. Since the 1760s, the officials stationed at Malabar received instructions to reduce the VOC settlements by selling them to native rulers as they could not manage all the VOC possessions. In 1771, the VOC fort at Cannanore was sold to the Ali Raja of Cannanore. Another VOC establishment, Fort Chettuwa, was deteriorating; thus, in 1763, Jan Schreuder, who was sent to inspect the VOC conditions in Malabar suggested that a new ronduit be built at Chettuwa where cannons could be amounted. Instead, the Governor-General in Batavia, Van der Parra demanded that the fort be demolished. ${ }^{9}$ The Fort was eventually sold to Tipu Sultan, ruler of Mysore in 1789. On 31 July 1789, the VOC forts at Cranganore and Aycotta were sold by Governor Van Angelbeck to Travancore for 300,000 Surat Silver Rupees. ${ }^{10}$ Thus, by 1795, the VOC's Malabar Command consisted of only Fort Cochin, two warehouses at Purakkad and Kayamkulam and a small establishment at Quilon. The year 1795 saw English victory in Malabar after their success in the Anglo-Dutch wars (1652-1784).

\section{Final thoughts}

Jim Endersby suggests that plants are essential (if often overlooked) characters in colonial relationships. ${ }^{11}$ As this thesis has shown, they could be traded for money, patronage and scholarly prestige in Europe. Dutch historians have analysed the relationship between the VOC and science in different ways. Femme S. Gastral calls the VOC a 'reluctant discoverer' owing to its inadequate support for navigational and scientific endeavours. ${ }^{12}$ Another Dutch historian coined the term 'een onwillige Mecenas' (unwilling patron) of science as the VOC only grudgingly allowed for the pursuit of natural historical knowledge by its employees. ${ }^{13}$ Leonard Blussé and Ilonka Ooms also stress this perspective. ${ }^{14}$ This thesis argues that contrary to the developments of science in the Dutch Republic, the VOC remained a reluctant patron for the pursuit of science. A case in point is the lack of patronage extended to Van Reede for his scientific activities. The lack of agreement

\footnotetext{
${ }^{9}$ Anjana Singh, Fort Cochin in Kerala, 1750-1830: The Social Condition of a Dutch Community in an Indian Milieu (Leiden: Brill, 2010), p.168.

10 Ibid.

11 Jim Endersby, “'From Having no Herbarium.” Local Knowledge versus Metropolitan Expertise: Joseph Hooker's Australasian Correspondence with William Colenso and Ronald Gunn', Pacific Science, Vol. 55, no. 4, 2001, p. 356.

${ }^{12}$ Femme S. Gaastra, 'The Dutch East India Company: A Reluctant Discoverer', The Great Circle, Vol. 19, no.2, 1997.

${ }^{13}$ Klaas van Berkel, 'Een onwillige Mecenas', in J Bethlehem and A.C. Meijer (eds.), VOC en Cultuur: Wetenschappelijke en Culturele Relaties tussen Europa en Azie ten tijde van de Verenigde Oostindische Compagnie (Amsterdam: Schiphouwer \& Brinkman, 1993), pp.39-58.

${ }^{14}$ Leonard Blusse and Ilonka Ooms (eds.), Kennis en Compganie: De Verenigde Oost-Indische Compagnie en de modern Wetenschap (Amsterdam: Balans, 2002), pp.1-11.
} 
between the officials stationed at the VOC settlements and the Company Directors and Government in Batavia did not work in favour of the Company rule in Malabar. The commercial potential in Malabar were overlooked by the Company in the eighteenth century.

Further research needs to be done to examine how the English pursued botanical activities and state-making, building on the Dutch legacy in the manner in which the Dutch had built on the Portuguese legacy in Malabar. Also, the Company activities in other settlements such as Ceylon, Batavia and Bengal need to be examined to see if the findings of the study would have a wider applicability to examine the knowledge-making activities of the Dutch East India Company in Asia. The study could further examine the role of the local population in the early modern knowledge networks by tracing the correspondence networks that connected Europe and Asia. This thesis concludes by arguing that the VOC had power in Malabar in the seventeenth and eighteenth centuries. However, without adequate patronage for the Company knowledge-making activities, it failed to deploy natural history knowledge for imperial pursuits. 


\section{APPENDIX I}

1) Schematic Presentation of the VOC Organization

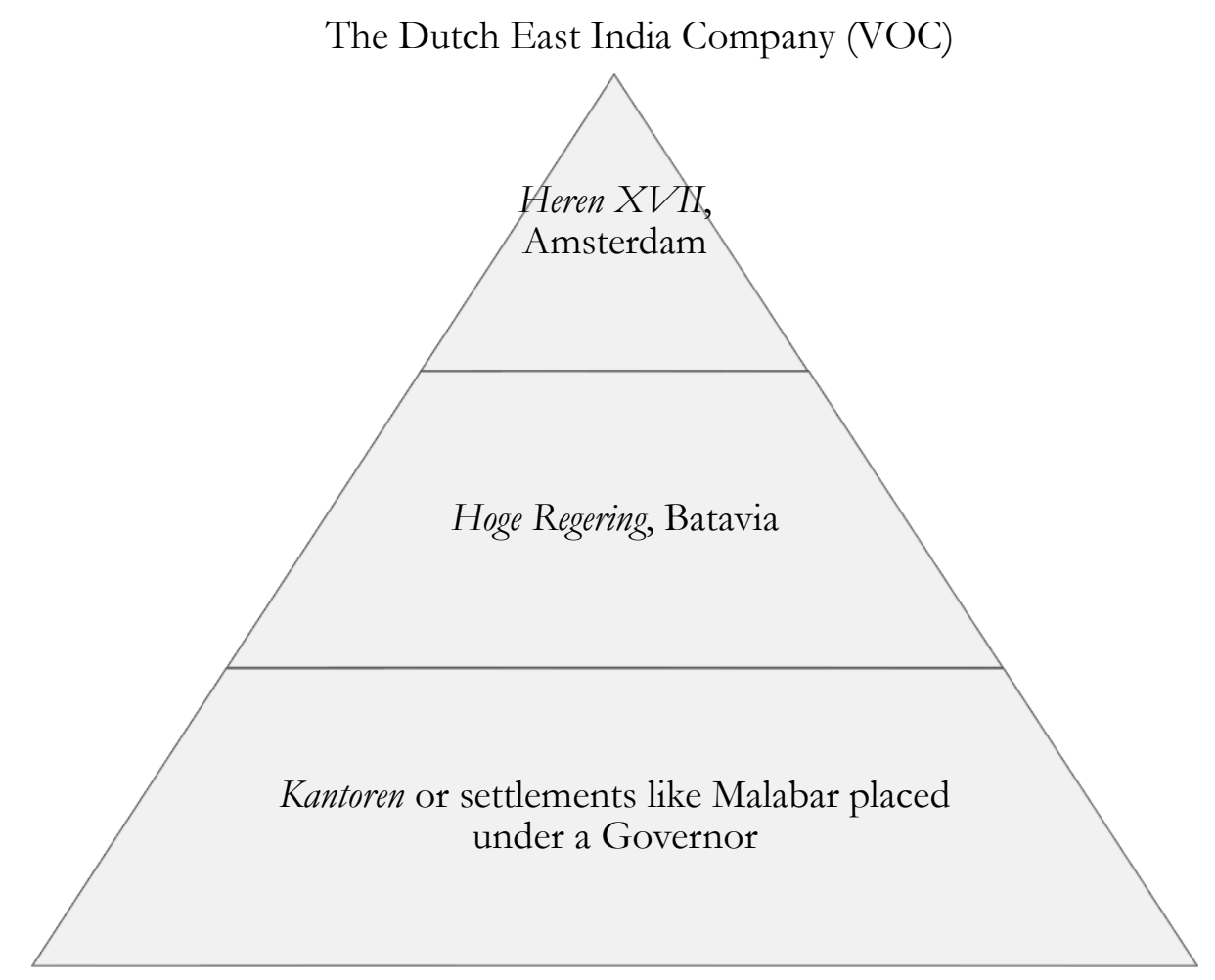


2) Patapattu written in the seventeenth century about the Portuguese-Dutch war in Cochin, 1663.

Left aside hesitancy, with officers

Met the shining king,

Saw the foreigner sumptuously.

'What tides bring you here

With what decision can I help you?

No divergence, ask, I will provide;

If not, Dutch is not our name!'

Said good words like this slowly,

After a bit of silence, the king

Straightened the body, and said happily:

'A recurring anxiety that irritated my mind

Is gone after the words of the Dutch governor

Many things are there to be done

To convince thee then I utter; listen

Today affecting all the enemies

The cherished Cochin kingdom

Due to the splits, enemies, relatives,

And some verdicts, I lost my kingdom.

Even the Portuguese left me,

Whom I had guarded with my life

Some muscled in, conquered the land.

They have some as allies, then

The Zamorin, despite his enmity,

Also cannot coronate us today,

As the Portuguese are on the other side.

The Portuguese who held the Cochin Fort

If expelled, the dream is materialized.'

Hearing these, the governor said sans hesitancy:

'Just after killing the enemies

I will coronate you dutifully.'

Hearing these, the governor said sans hesitancy:

'Just after killing the enemies

I will coronate you dutifully. ${ }^{1}$

${ }^{1}$ The entire song can be found in, Mahmood Kooria, Patappattu, a Malayalam War-Song on the Portuguese Dutch Battle in Cochin' in Mahmood Kooria and Michael Pearson (eds.), Malabar in the Indian Ocean: Cosmopolitanism in a Maritime Historical Region (New Delhi: Oxford University Press, 2018), pp.141-171. 


\section{APPENDIX II}

1) Van Reede's life and journey to different the VOC posts in years

Van Reede's early years: 1636-1650

Cape of Good Hope: 1657

Batavia: 1657

First captain and sergeant major of Ceylon 1667-1669

Commander of Malabar 1670-1677

Extraordinary Councillor of India 1677

Van Reede in the Netherlands 1678-1684

Cape of Good Hope 1685

South Ceylon 1685

Bengal 1686-1687

Coromandel 1687-1689

North Ceylon 1689-1690

Tuticorin 1690-1691

Malabar 1691

Death 1691 (at sea close to Surat). 
2) Contents of Twelve volumes of Hortus Malabaricus

\begin{tabular}{|c|c|c|}
\hline $\begin{array}{c}\text { Volumes } \\
1 \\
\end{array}$ & $\begin{array}{c}\text { Contents } \\
\text { On various Trees and podded fruits }\end{array}$ & $\begin{array}{c}\text { Year of publication } \\
1678 \\
\end{array}$ \\
\hline 2 & Shrubs & 1679 \\
\hline 3 & Trees & 1682 \\
\hline 4 & Fruit bearing Trees & 1683 \\
\hline 5 & Trees and berry bearing trees & 1685 \\
\hline 6 & Trees bearing podded trees & 1686 \\
\hline 7 & Various kinds of climbing shrubs & 1688 \\
\hline 8 & $\begin{array}{l}\text { Various genera of fruit-bearing and } \\
\text { leguminous herbs }\end{array}$ & 1688 \\
\hline 9 & Herbs and their diverse Species & 1689 \\
\hline 10 & Herbs and their diverse Species & 1690 \\
\hline 11 & Herbs and their diverse Species & 1692 \\
\hline 12 & Herbs and their diverse Species & 1693 \\
\hline
\end{tabular}




\section{APPENDIX III \\ 1) Public Notice printed in London notifying the proposed publication of the translations of Hortus Malabaricus in English by John Hill. ${ }^{2}$}

London 15 Feb 1774

\section{Public Notice}

The folio edition of Hortus Malabaricus being very rare for a long time and only obtainable at a high price, Doctor Hill of London to conserve this excellent work for posterity at a reasonable price has determined to give to his own [?] a new complete edition in Latin, in 12 quarto volumes, with several of his own additions.

To bring out this edition with all possible advantages, something like $£ 2000$ sterling will be spent. It will be printed on fine paper, in a typeface never before used, the plates will be faithfully copied from the originals and engraved by master engravers, 12 of whom will be employed on this. And so that the references of the authors will match from one edition to the other, it will be a facsimile [I am loosely translating this sentence but that's what it means].

The additions which the editor will give at the end of each chapter are the following, according to Linnaeus' system, as follows:

1 the class of the plant

2 its genus (literally, generic characteristic)

3 species (literally, specific name)

4 other names

5 observations, quotations, etc, of other authors on the same subject

6 at the end of each volume a Linnaean index

By these additions this excellent work will be even more perfect and more useful, and among the other advantages one will identify the plant by its proper name along with its primitive names.

The first volume will be published next May, containing 130 pages and 57 plates. Its price will be one guinea ( 21 shillings) unbound, and the following volumes every three months at around the same price according to the number of pages.

A few copies will be printed on fine imperial paper at $f_{1} 1.8 .0$ the volume [ 28 shillings] and some with coloured plates at three and a half guineas each.

Enthusiasts for natural history who want to buy this new edition should enquire of their bookshops in the principal cities of Europe.

2 The public notice has been loosely translated from French. I would like to acknowledge Prof. Jim McAloon, School of History, VUW for his considerable help in translating the notice from French. 


\section{2) Letter written by John Hill to the French botanist Michel Adanson ${ }^{3}$}

London this 21 Febr. 1774

Sir,

I hope you will have received my books now. Gentlemen Saillant and Nyon have dispatched their package to me, before you were able to give them yours [your packages], you can have yours be delivered either to Mr. Didot the Younger or to Mr. Desvantes Dela Dué, with whom I am in touch and who will accept them so they can deliver them to me some time.

Having mentioned to you in my last [letter ?] a new edition of the Hortus Malabaricus which I am publishing with my additions, I thought I should give you the preface..., so that you have a better idea of it. I would be very honored to hear your thought[s] and opinion on this enterprise. And if you have the opportunity to recommend the book to your friends, or to some booksellers, you would bring me great pleasure [e.g. you will make me very happy].

Your cabinet of natural curiosities is still being considered by Mr Daldon. One must have patience. I will do everything that I can to serve you and will inform you of the present state in time. In the meantime, permit me to assure you of my respects, having the honour to be with the most perfect esteem and consideration.

Sir

Your very humble and very

Obedient servant

J Hill

P.S. If Mr Saillant \& Nyon hand you

an imperfection for me [?], have the kindness to accept it

and put it in your package, or hand it over [to]

Mr. Adanson, $\quad$ to Mr Didot or Desvante

\footnotetext{
${ }^{3}$ Untitled letter, Royal Society of London Publishing, 1774. The letter in French was translated into English by Dr. Catherine Abou-Nemeh, Lecturer in Early Modern History at VUW on 13 June 2019. I thank her for the meticulous translation from French.
} 


\section{APPENDIX IV}

\section{1) The Dutch East India Company military engineers and surveyors of Malabar}

1663-64 Cornelis van Woensel, land surveyor, fabriek (factory) and military engineer $1678 \quad$ Nicolaus de Graaff

1679-84 Laurens Nicolaesz (Claasz) Durendal, land surveyor and military engineer

1688 Maxmiliaen Stoffelz, inspector of fortifications

1689-1712 Hans George Jurge Tarand, factory and military engineer

1691 Hans Jurgen Konsteman, inspector of fortifications ${ }^{4}$

$1720 \quad$ Pieter Gijsbert Noodt, inspector of forts

1765 W. O Massenfeld D. Zijnen, Captain and Lieutenant Engineer

1767 E. Paravicini de Capelli and J. L Guyard, military engineers

1782 Carl von Krause, Land Surveyor

${ }^{4}$ Zandvliet, Mapping for Money: Appendices: 274. 


\section{APPENDIX V}

\section{1) Conditions of Lease $\left(1^{\text {ST }} \text { January } 1756 \text { to } 31^{\text {st }} \text { December } 1765\right)^{5}$}

\section{7}

Conditiën en voorwaarden waarop den E[dele] Agtb[are] heer command[eu]r Fredrik Cunes, mitsgaders den Raad desercusten van wegens d'Edele Nederlandse OostindischeConp[agnie] voornemens sijn aan de meestbiedende bij openbare afslag te verhuuren ofte verpagten de naargen[oemde] thuynen en landerijen voor den tijd van thien naastvolgende jaren te weten

\section{Conditions of lease for ten years}

1. De verpagting zal ingaan $\mathrm{p}$ [ri]mo Januarij 1756 en eyndigen ult[im]o December 1765 en de betaling zal moeten geschieden in specie Cochimse fanums alle ses maanden de helfte. En so sal den pagter gehouden wesen de bedongene pagtpenn[ingen] twee maal's jaars te betalen. En die borg medestander of beth ... (8318) hebbende van de pagt wil zijn naib zijn zullen haar eerstens moeten aangeven om in desen genoteerd te wesen tot voorkoming van disputen.

The lease will be from January, 1 st 1756 until the end of December 1765 and has to be paid every six months half. The sureties has to bementioned in the deed.

2. Den pagter sal gehouden zijn te stellen twee suffixante borgen, christen en onderdaanen, en die subject zijn de judicature van d'E. Comp[agnie] en die wel speciaal[ijk] sullen moeten be.....cieeren de exceptiën ..... excussiaris et di...ciaris, dat is afstanddoening der versetten van ....gang, uitwinningen en splitsingen van de schuld. Also hetselve onder hun geen plaats zal hebben, maar elk een voor de betaling aanspreekelijk en executabel blijven.

The tenant has to put two guarantors, being Christians, subjects of the Company and its judiciary. The sureties will renounce of all rights of excuse and be accountable for the full payment of the rent.

3. Ook zal een persoon alleen voor zichzelfs niet meer als een stuk land of thuyn, ten uitterste twee met speciaal consent, mogen mijnen. En den welken als dan ook verpligt zal wesen het gem[eende] land, thuyn, ofte thuynen onder sijn eigen opsigt, verantwoording en sorge te houden, sonder (8319) daarvan aangemand anders het geheel ofte ten deele af te geven, dan wel voor meerder bedragen verhuuren als met speciaal consent en daarvan aanteekening te laten doen en registreeren tot voorkoming, gelijk gesegt is, van alle moeyelijkheden die door versuim gemeenlijk komt te ontstaan.

\footnotetext{
${ }^{5}$ Tamil Nadu State Archives Chennai, Cocbin Records: No: 600, 'Conditions of Lease $1^{\text {ST }}$ January 1756 to $31^{\text {st }}$ December 1765'. The translation to English is done by author of the thesis. I would like to acknowledge the guidance of Hugo s' Jacobs, Emeritus Professor of History, Groningen University for checking my draft on the translation of the document.
} 
One is allowed to obtain at an auction only one piece of land, or two with special approval only. The tenant has to keep the land under his own care and supervision on the penalty to return it fully or partly. Only with special approval is he allowed to let the land for a higher rent and he is obliged to get this registered.

4. De huurders sullen gehouden wesen de landerijen etc. so veel haar mogelijk is te verbeteren, vergroten, bedijken, van de bossen suyveren, beplanten en de zoutpannen vermeerderen, so veel mogelijk is ende plaats leyden kan en haar van de opsienders der landen naar discretie zal aangewesen worden, opdat zulx soude mogen gedijen en tot haar eygen voordeel.

The tenants are obliged to improve their lands, to enlarge, embank them, to clear bushes and to augment the salt pans as much as possible and the place can have and will be directed by the overseers, as that they will become better in their own advantage.

5. Zonder egter de kocusbomen te mogen uitmergelen, mag ook geene omkappen dan met speciaal consent van de geme[elte] oogsienders, maar zullen gehouden in de plaats daar (8320) van aan te planten.

Without overexploiting the coconut trees, none will be felled without special license of the overseers and it shall be substituted.

6. De voors[eyde] aanplantinge der bomen sal moeten geschieden binnen den tijd der drie naest volgende jaaren, dat is jaarlijx een derde deel van het geheel. Invoegen dat naar gedane informatie en rijpe calculatie bij ieder thuyn of eyland specifice tot iders naarigt staad te werden uytgeduidt.

The mentioned planting of trees has to be done within three years, to wit yearly one third of all. As will be indicated specifically for every garden or island after due calculation.

7. Dengenen die bevonden word hieromtrent in gebreke te sijn gebleven, of dat hij op ieder jaar zijn pligt niet heeft waargenomen, integendeel daarin moetwilliglijk gemanqueert sal hebben, sal van den pagt versteeken wesen en geen pretensie behouden van eenige onkosten die aan de landerijen en thuynen sijn gedaan, maar bovendien verbeuren een boete van 6 rds., de eene helfte voor de opsienders der landerijen en de andere helfte (8321) voor de diaconij deser steede.

Who fails to pay the rent for one or more years will lose his tenancy and reimbursement of costs spent on the land and will be fined with 6 rix dollars, half in favour of the overseers and half for the deacons of Cochin Fort.

8. En zal dan terstond bij nadere afwijkinge een andere pagter in des gebrekens plaatse toegelaten werden, mitsgaders het mindere aen pacht door den gewesen pagter ofte zijne, moeten werden voldaan, sonder van het meer bedragen iets te profiteeren.

A new tenant will be admitted directly, and may it be for a lower rent the deficit has to be paid by the former tenant, while he is not entitled to receive a surplus.

9. Die eenige thuyn, ofte thuynen komt te pagten en in gebreke blijft aanstonds tot genoegen de nodige borgen te stellen, sal almede aan de pagt versteeken zijn en moeten gedogen dat die aanstonds de novo opgeveylt werde. Sullende 't minder geldende dan eerst geboden is, door hem moeten betaald werden en het meerder bedragen ten voordeele van d'E. Comp[agnie] blijven. 
If a tenant fails to provide sureties he will lose the lease directly and it will be put for sale immediately. He will be liable to pay a deficit in the new rent, while a surplus will be for the Company.

10. Zoo het quam te gebeuren dat d'E. Comp[agnie] om een groote quantiteid olas, oude boeken, of andere bonnen benodigd mogte wesen, zullen die met behoorlijke discretie ge (8322) bragt en afgehaald, mitsgaders dan ook na advenant toegestaan werden een billijke afslag in de bedongene pagtpenn[ingen].

If enough olas, old books or other deeds are brought forward as proof of a lower rent, a reduction will be permitted.

11. Den pagter staande dese huurtijd van 10 jaren komende te verschijden, sal de pagt geensints overgaan nogh aan zijn erfgenamen toevallen, dan alleen met speciale consent en toestemming van de Command[eu]r en den Raad daarin continueeren.

The lease will not be heritable and can be passed to heirs only with approval by Commander and Council.

12. Den pagter zal gehouden wesen in 't begin van den grote nelij oegst, dat is eenmaal 's jaars, alsmede van de kocusnoten tweemaal in 't jaar den hoofdadministrateur aan te bieden ten minste de helfte van de ingekomene quantiteid om te dienen tot afbetaling der bedongene pagtpenningen, den prijs te rekenen als de markt dan wesen zal.

With the main nely harvest, namely once a year and with the coconut harvest twice a year the tenant has to offer the chief administrator or second in charge half of the yield in payment of the rent and valued according to the market price.

13. Zoo zal den pagter ook gehouden en verpligt wesen aan degene die 't oversigt over de gem[elte] thuyn en landerijen heeft en overal een vlijtig (8323) oog moet laten gaan, dan wel die na dese dien last zal worden opgelegd, jaarlijx moeten betalen 2 Cochimse basseroeken voor ieder vruchtdragende boom sonder onderscheid.

The tenant has to pay the overseer or his successor every year two Cochin budgrooks for every productive tree.

14. Den pagter zal geen wilde canneel op 's Comp[agnies] landen mogen laten groeyen, maar die ten eersten moeten doen uitroeyen en verbranden, bijaldien deselve op het land mogt gevonden werden. Dog den peper en gember zal eenider daarop wel mogen aanplanten.

Wild cinnamon has to be removed and burned, yet pepper and ginger will be planted.

15. De pagters van Bendoertij, Ilha de Lettij, het Musquite, Paulisten en andere eylanden, sullen ook de ordinaire geregtigheyt genieten van alle de swaartvis die omtrent en onder deselve door de vissers met hun netten mogten werden gevangen. Maar van de andere vangsten zullen zij niet te pretendeeren hebben.

The tenants of Bendoertij, Ilha de Lettij, the Mosquito-, Paul's - and other islands will have the common tax on the swordfish caught by the fishermen of these islands. On other catch they have no rights. 
16. De huurder sal gene andere pagters mogen hebben, nog toelaten dan (8324) die Christenen onderdanen van d'E. Comp[agnie] en op dat land woonagtig zijn, mits daarvan geven behoorlijke voorkennisse.

The tenant is only allowed to sublet the lease to Christian subjects of the Company and dwelling on the land provided giving due notice in advance.

17. Die eenige bod bied zal gehouden wesen hetselve gestand te doen totdat met zijne borgen daarvoor getekend heeft dat tenminste binnen den tijd van 24 uuren sal moeten geschieden. En so twee tegelijk mijnden en daaruit questie mogte komen te ontstaan, so sal het aan den Commandeur en Raad staan om de pagt te gunnen die het haar E[delheden]s goet dunken zal.

A bid has to be kept until signed by the tenant and his two sureties within 24 hours. In case of two similar bids the Commander and Council decide who will get the lease.

Summary

The leasing out of St. Jago inclusive a garden on Senhora de Saude. List of produce, tenant is tupas Amaro de Souza, rent 25,000 Cochin fanums, sureties the Christians Choelikel Mingo and BrahalikelKitto. (dated) Cochim, December 17, 1755. 
2) Memorandum of gardens and lands belonging to the VOC on the coast of Malabar: dated $1781 .^{6}$

1. The island Bendurty lying half an hours south of this town, containing 4,990 fruit-bearing coconut and other trees, 314 parras of cultivated lands, 9,300 salt-pans.

2. A garden called David de Castella lying at Aru about two hours south of this town, containing: 3,275 fruit-bearing coconut and other trees, 490 parras of cultivated lands, 2,980 salt-pans.

3. A garden called St. Jago lying by the third Roman Church on the southern shore of Cochin, containing: 3,116 fruit-bearing coconut and other trees, 48 parras of cultivated land.

4. A garden called Hendrik de Silva lying at Malambelly one and a half hours south of

Cochin on the sea-shore, containing: 1,659 fruit-bearing coconut and other trees, 728 parras of cultivated land.

5. The island Muttucunu and two [islands] belonging to it lying nearly half an hour south of Cranganur, all three containing:

3,673 fruit-bearing coconut and other trees, 531 parras of cultivated land.

\footnotetext{
${ }^{6} \mathrm{MvO}$ Adriaan Moens, 250-253: dates 1781, also published in A. Galletti, A. J. van der Burg and P. Groot, The Dutch in Malabar (Madras: Government Press, 1911 reprint Delhi 1984): 250-253.
} 
6. A garden called Illawada lying west of the company's outside garden, on the shore,

containing:1,563 fruit-bearing coconut and other trees, 503 parras of cultivated land.

7. The island Calliacatte or Morenbril lying in the back-water between Calicoilan and Coilang, containing:

5,462 fruit-bearing coconut and other trees, 41 parras of cultivated land, 1,300 salt-pans.

8. The island Bettenienny lying a little to the east of the above mentioned island Callicatte, containing:

423 fruit-bearing coconut and other trees, 2 parras of cultivated land.

9. A garden at Calichery Bitjur lying to the east of the back-water,8 hours south of Cochin, containing: 1, 570 fruit-bearing coconut and other trees, 44 1/2 parras of cultivated land.

10. A garden at Purpencarre called Mathys Mendes, containing: 315 fruit-bearing coconut and other trees, 4 parras of cultivated land.

11. A garden at Purpencarre called Anthony Fernando Piloot, containing: 257 fruitbearing coconut and other trees, 22 parras of cultivated land.

12. A garden at St. Andries lying six hours from Cochin, containing: 983 fruitbearing coconut and other trees, $441 / 2$ parras of cultivated land.

13. A piece of land called Gasany on Vypeen island, containing: 108 fruit-bearing coconut and other trees, 225 parras of cultivated land.

14. A garden called Bellestor Rodrigus lying one hour south of this town, containing: 195 fruit-bearing coconut and other trees, 10 parras of cultivated land.

15. The Verdronken (submerged) island lying north-east in the back-waters in front of Cochin, containing: 14 parras of cultivated land, 400 salt-pans.

16. A little parcel of land on the shore south of the company's outside garden, containing:

96 fruit-bearing coconut and other trees, 5 parras of cultivated land.

17. A little parcel of land behind or beside the Banyas' village, containing: 
177 fruit-bearing coconut and other trees, 1/2 parra of cultivated land.

18. Five parcels of land lying west of the Sacrifice Tree in Canarin bazaar, containing:

34 fruit-bearing coconut and other trees, 1 parra of cultivated land.

19. Two little gardens lying on the old channel from the Canarin bazaar, containing:

213 fruit-bearing coconut and other trees, 300 salt-pans.

20. Ten little parcels of land lying between the two channels on this side of the Canarin

bazaar, containing: 513 fruit-bearing coconut and other trees, 180 salt-pans.

21. A garden lying east of the company's outside garden, containing: 314 fruitbearing coconut and other trees, 8 parras of cultivated land.

22. A piece of land called Malliencarre opposite to the out-post Aycotta, containing: 487 fruit-bearing coconut and other trees, 25 parras of cultivated land.

23. The plain (military free zone), beginning at the company's garden and ending at Calvetty: a piece of land lying north of St. Andries, containing:

289 fruit-bearing coconut and other trees, 2 parras of cultivated land.

24. A piece of land of 1,699 roods in extent lying at Calvetty on the side of the channel from

the Canarin bazaar, containing:112 fruit-bearing coconut and other trees, 10 parras of cultivated land.

25. A piece of land at Cattur, containing:

166 fruit-bearing coconut and other trees.

26. The island of Malliencarre, opposite the out-post Aycotta, containing: 466 fruitbearing coconut and other trees, 20 parras of cultivated land.

27. A piece of land at Paliaporte (Pallipuram) on which the trees have been cut down and the lease money has been reduced, but is still planted with: 
243 fruit-bearing coconut and other trees,

28. A garden at St. Andries, containing:

298 fruit-bearing coconut and other trees, 5 parras of cultivated land.

29. A garden lying at Carcarpally, containing:

121 fruit-bearing coconut and other trees.

30. A garden lying at Cheramangalam 8 hours south of Cochin, containing:

69 fruit-bearing coconut trees.

31. A garden at Manicorda, containing:

493 fruit-bearing coconut and other trees,

32. A garden called Hendrik de Silva Pequena, containing:

1,119 fruit-bearing coconut and other trees,

20 parras of cultivated land.

33. A garden at Senhora De Saude, containing:

1,222 fruit-bearing coconut and other trees, 29 parras of cultivated land

34. A garden at St. Louis, containing: 333 fruit-bearing coconut and other trees, 7 parras of cultivated land.

35. The Musquiten (Mosquito) island opposite to Cranganur, containing:

233 fruit-bearing coconut and other trees, 308 parras of cultivated land, 103 salt-pans.

36. A garden at Crus de Milager, containing: 100 fruit-bearing coconut and other trees, 2 parras of cultivated land. 
37. The Paulist Island, otherwise called Wallerpart, containing: 676 fruit-bearing coconut and other trees, 325 parras of cultivated land,1,324 salt-pans.

38. The garden called Ballegatty (Bolgatty), containing: 297 fruit-bearing coconut and other trees, 562 salt-pans.

39. A garden at Angecaimaal, containing: 82 fruit-bearing coconut and other trees, 92 parras of cultivated land.

40. A garden called Catharina Cardoza at Irreweni, containing: 82 fruit-bearing coconut and other trees, 4 parras of cultivated land.

41. A garden called Joan Correa de Silva, containing: 148 fruit-bearing coconut and other trees, 4 parras of cultivated land.

42. A garden at Castella, one and half hours south of Cochin, containing: 930 fruitbearing coconut and other trees, 20 parras of cultivated land.

43. A garden called Ilha de Lethy, or Carmarta: lying near Cranganur, containing: 338 fruit-bearing coconut and other trees, 80 parras of cultivated land.

44. A garden called Domingo Fernando lying one hour from Cochin, containing: 217 fruit-bearing coconut and other trees, 42 parras of cultivated land.

45. The island St. Domingo lying half an hour north-east of Cochin, containing: 476 fruit-bearing coconut and other trees, 126 parras of cultivated land, 900 salt-pans.

46. A garden at Aycotta of 3 parcels of 21,281 1/2 roods, containing: 587 fruit-bearing coconut and some other trees, 2 parras of cultivated land.

47. A garden at Aycotta of 2 parcels, containing: 721 fruit-bearing coconut trees, 6 parras of cultivated land. 48. A garden at Aycotta of 2 parcels, containing: 631 fruit-bearing coconut trees, 2 parras of cultivated land.

49. A garden at Aycotta of 2 parcels of land, containing: 359 fruit-bearing coconut trees. 
50. Still another garden at Aycotta of 4 parcels of land, containing: 182 fruit-bearing coconut trees.

51. A garden lying on the old channel of the Canarin bazaar, containing: 66 fruit-bearing coconut and some other trees, 1 parra of cultivated land.

52. A little garden lying near Calvetty, containing: 22 fruit-bearing coconut trees.

53. A garden lying at Alipe of nine hours south of Cochin, containing: 76 fruitbearing coconut and some other trees,

2 parras of cultivated land.

54. A garden on the Vreede (Peace) island at Allepaar lying 2 or 3 hours north of Coilan, containing:

265 fruit-bearing coconut and other trees, 30 parras of cultivated land, 490 salt-pans.

55. Two little pieces of land, or cultivated fields of 32 parras in extent lying near Aycotta. 
3) Dutch Commanders in Malabar 1751-1795

1751-1756 Frederik Cunes

1756-1761 Casparus de Jong

1761-1764 Godefried Weyerman

1764-1768 Cornelis Breekpot

1768-1770 Christiaan Lodewijk Senff

1770-1781 Adriaan Moens

1781-1793 Johan van Angelbeck

1793-1795 Jan Lambertus van Spall 


\title{
BIBLIOGRAPHY
}

\section{Primary Sources}

\author{
Unpublished
}

National Archives of the Netherlands, The Hague

Archives of the Vereenigde Oostindische Compagnie (VOC)

Archives of the Hoge Regering, Batavia (HR)

Family archives of Adriaan Moens

Family archives of Rijklof van Goens

\section{Maps and Drawings:}

Verzameling buitenlandse kaarten, Leupe (Foreign maps collection, Leupe, VEL).

TANAP website: http://www.tanap.net/content/voc/history/history managevoc.htm: accessed on 23 August 2019.

Koninklijke Bibliotheek (KB), The Hague, The Netherlands

Boekhouder-Generaal Batavia, Huygens Institute for the History of the Netherlands (accessed 11 April 2020 https://bgb.huygens.knaw.nl/bgb/voyage/7792).

Database of VOC voyages, knaw.nl. (last accessed on 6 June 2020 http://resources.huygens.knaw.nl/das/detailVoyage/96997).

\section{National Archives of the Republic of Indonesia, Jakarta (Digital Resources)}

Archives of the Governor-General and the Councillors of the Indies

Dagh-registers gehouden int Casteel Batavia

Harta Karun: Indonesia.https:// sejarahnusantara.anri.go.id/bartakarun/item/19/transcription accessed 12 May 2019.

Realia files 
Contract of Andries Cleyer, Batavia, 1700.

Chineese Medicamenten, 13 Dec 1665, Realia 1610-1808

Conditions for Preparing Chinese Medicines, Realia 1610-1808.

\section{Tamil Nadu State Archives, Madras, India}

\section{Cochin Dutch Records}

The Conquest of Paponetty

Boundary Settlement of Pappinivattom, 1717, Cochin Records

Conditions of Lease $1^{\text {st }}$ January 1756 to $31^{\text {st }}$ December 1765

Twenty years of leases of Co's gardens and fields 1781 to 1800, Cochin records

Conditions of lease 1707 to 1710 , Cochin records

Leases dated 1764, Cochin Records

\section{Kerala State Regional Archives, Ernakulam (KSA)}

\section{Series files (1684-1869) Central Records}

Company Treaty, 6 April 1698

Treaty 1663 signed between Rijklof van Goens and Malabar Princes

Treaty 1663 signed between Rijklof van Goens and the ruler of Cochin

\section{Published Primary Sources}

Buchanan, Frances, A Journey from Madras through the Countries of Mysore, Canara and Malabar, Vols. III (London: W. Bulmer and Co., 1807).

Commelin, Caspar, Flora Malabarica sive Horti Malabarici catalogus exbibens omnium eiusdem Plantarum nomina, quae è variis, tum veteribus tum recentioribus Botanicis collegit, \& in ordinen Alphabeticum digessit (Leiden: Apud Fridericum Haaringh, 1696)

Commelin, Jan, Hortus Medicus Amstelodamensis (Amsterdam: P and J Blaeu, 1697).

Dagh-register gehouden int Casteel Batavia vant passerende daer ter plaetse als over geheel Nederlandts-India 1670-71 (Batavia: G. Kolff, 1989). 
Drakenstein, Hendrik van Reede tot, Hortus Indicus Malabaricus, continens Regni malabarici apud Indos celeberrrimi omnis generis plantas rariores, latinis, malabaricis, arabicis, \& bramanum characteribus nominibu(s)que expre(ss)as, una cum floribus, fructibus \& (s)eminibus, naturali magnitudine a periti(ss)imis pictoribus delineatas, \& ad vivium exhibitas..., 12 vols. (Amsterdam: 1678-1693).

De Nederlanders in Kerala 1663-1701: De memories en instructies betreffende het commandement Malabar van de Verenigde Oost-Indische Compagnie, edited by H. K. s'Jacob ('s-Gravenhage: Martinus Nijhoff, 1976).

Fryer, Geoffrey, 'John Fryer and His Scientific Observations made Chiefly in India and Persia between 1672 and 1682', Notes and Records of the Royal Society of London Vol. 33, no. 2, 1979.

Fryer, John, A New Account Of East-India and Persia, In Eight Letters Being Nine Years Travels Begun 1672, And Finished 1681 (London: RR, 1698).

Gommans, Jos, Jeroen Bos and Gijs Kruijtzer (eds.), Grote Atlas van de Verenigde Oost-Indische Compagnie: India, Persia and Arabian Peninsula (The Hague: National Archives, 2014)

Hamner, Thomas, Ivy Elstob (trans.) and Eleanour Sinclair Rohde (eds.), The Garden Book of Sir Thomas Hamner, Brat (1659) (London: Gerald Howe, 1933)

Jones, William, The Works of Sir William Jones in Thirteen Volumes, Vol. II (London: John Stockdale, 1807)

Letters from Cochin Rajas to Batavia. Records in Oriental Languages, Cochin State, Book II. (Ernakulam: Cochin Government Press, 1946).

Maria Sybilla Merian, Metamorphosis Insectorum Surinamensium ofte Verandering der Surinaamsche Insecten (Amsterdam: G. Valck, 1705).

Memoir written in the year 1677 A. D. Reede tot Drakestein, Hendrik van, 1637-1691 (Madras: Madras Government Press, 1911).

Memorie door den afgaande Commandeur Godefridus Weijerman aan desselfs vervanger den we ledelen heeraan komende Commandeur Cornelis Breekpot overgegeven de dato 22 februarijao. 1765. Selections from the Records of the Madras Government: Dutch Records No. 12, edited by P. Groot (Madras: Government Press, 1910) MvO Godefridus Weyerman: dated 1765.

Memorienagelaten door den afgaande E.E. Commandeur Casparus de Jong aan desselfs vervanger den E.E. agtb heer Godefridus Weijerman gedagteekend den 7 maart 1761. Selections from the Records of the Madras Government: Dutch Records No. 11, edited by P. Groot (Madras: Government Press, 1910) MvOCasparus de Jong: dated 1761.

Peter Reynders in Rupert Gerritsen (ed.) A translation of the Charter of the Dutch East India Company (Verenigde Oostindische Comapgnie or VOC): Granted by the States General of the United Netherlands, 20 March 1602 trans. (Canberra: Australia on the Map Division of the Australasian Hydrographic Society, ANU, 2009). 
Ray, John, Historia plantarum: species hactenus editas aliasque insuper multas noviter inventas \& descriptas complectens (London: Printed by Henry Faithorne, 1686-1704).

Rheede, Adriaan van, trans. K. S. Manilal, Van Rheede's Hortus Malabaricus, Vol I-XII (Thiruvananthapuram: University of Kerala, 2003).

The Dutch in Malabar being a Translation of Selections nos. 1 and 2 with Introduction and Notes. Selections from the Records of the Madras Government. Dutch Records no. 13, edited by A. Galletti, A.J. van der Burg, and P. Groot (Madras: Government Press, 1911). MvO van Gollenesse: dated 1743 and $\mathrm{MvO}$ van Adriaan Moens: dated 1781.

Untitled letter, Royal Society of London Publishing, 1774.

Van Rheede's Hortus Malabaricus English Edition With Annotations and Modern Botanical

Nomenclature, Vol. 2, 'Dedication' by K. S. Manilal (Thiruvananthapuram: Kerala University Press, 2003).

\section{Journals}

Philosophical Transactions of the Royal Society of London:

1. "An account of part of a collection of curious plants and drugs, lately given to the Royal Society by the East India Company", Philosophical Transactions of the Royal Society of London, Vol. 22, no.264, 1701.

2. "An Account of Some Books", Philosophical Transactions of the Royal Society of London, Vol. $13,1683$.

3. "An Account of some Indian Plants, with their Names, Descriptions and Vertues Communicated in a Letter from Mr. James Petiver, Apothecary and Fellow of the Royal Society; to Mr. Samuel Brown, Surgeon St. Fort St. George”, Philosophical Transactions of the Royal Society of London (1698).

4. Commentary on the First Three Volumes of Hortus Malabaricus (author unknown), Philosophical Transactions of the Royal Society of London, 1683.

5. Warner, Majorie F., 'The Dates of Rheede's Hortus Malabaricus', The Journal of Botany, Vol. 58, December 1920 (not paginated).

\section{Digital Images}

\section{Rijksmuseum Collections, Amsterdam}


Profiel van Amsterdam, gezien vanaf het IJ, 1611, Rijksmuseum Collection, Ref No. RP-P-OB103.723, (accessed on www.rijksmuseum.nl 23 May 2020

'Still Life with a Tall Beer Glass by Jan van de Velde (1647)', (accessed12 July 2019)

Simon de Vries, 'Curieuse aenmerckingen der bysonderste Oost en West-Indische verwonderenswaerdige dingen, deel 1 (accessed 23 February 2020).

\section{Other digital collections}

Botany at the Edward Worth Library: Hortus Indicus Malabaricus, https://botany.edwardworthlibrary.ie/floras/asia/hortus-indicus-malabaricus/ accessed 05 June 2019.

Jan Commelin by Gerard Hoet, Inventory Nr. SA 41466, Amsterdam Museum. Accessedonline http://am.adlibhosting.com/amonline/advanced/Details/collect/39423 on 1 July 2020.

Tenga', Hortus Indicus Malabaricus, Wellcome

Collection, https://wellcomecollection.org/works/f9s33ejx accessed 10 June 2019.

The Leiden Botanical Garden Orangery', Fagel Orchids and Orangeries Collection, The Library of Trinity College, Dublin.

\section{Newspapers}

Rangarajan, Mahesh, 'Crusoe Along', The Telegraph, 10 November 1995.

Siegal, Nina, 'A Dutch Golden age? That's Only Half the Story', New York Times, 25 October 2019. https://www.nytimes.com/2019/10/25/arts/design/dutch-golden-age-andcolonialism.html accessed 23 February 2020).

\section{Secondary Sources}

Aa, A.J. van der, Biographischwoordenboek der Nederlanden. Deel 16 (Haarlem: J. J. Van Beedeeode, 1874).

Abou-Nemeh, Catherine S., 'The Natural Philosopher and the Microscope: Nicolas Hartsoeker Unravels Nature's “Admirable CEconomy”, History of Science Vol. 51, no. 70, 2013, pp. 1-32.

Alpers, Svetlana, The Art of Describing: Dutch Art in the Seventeenth Century (Chicago: The University of Chicago Press, 1983).

Antunes, Catia and Jos Gommans (eds.), Exploring the Dutch Empire: Agents, Networks and Institutions, 1600-2000 (London: Bloomsbury, 2015). 
---- 'Birthing Empire: The States General and the Chartering of the VOC and the WIC' in René Koekkoek, Anne-Isabelle Richard and Arthur Weststeijn (eds.), The Dutch Empire between Ideas and Practice, 1600-2000 (Cham: Springer International Publishing, 2019), pp.19-36.

Arasaratnam, Sinappah, 'The Rice Trade in Eastern India 1650-1740', Modern Asian Studies, Vol. 22, no.3, 1988, pp.531-549.

Arnold, David and Ramachandra Guha (eds.), Nature, Culture and Imperialism: Essays on the Environmental History of South Asia (New Delhi: Oxford University Press, 1995).

Baber, Zaheer, 'The Plants of Empire: Botanic Gardens, Colonial Power and Botanical Knowledge', Journal of Contemporary Asia, Vol. 46. no. 4, 2016, pp. 659-679.

Ballantyne, Tony, Webs of Empire: Locating New Zealand's Colonial Past (Wellington: Bridget Williams Books, 2012.)

---- 'Empire, Knowledge and Culture: From Proto-Globalization to Modern Globalization' in A. G. Hopkins (ed.), Globalization in World History (London: Pimlico, 2002), pp.115-140.

Batsaki, Yota, Sarah Burke Cahalan and Anatole Tchikine (eds.), The Botany of Empire in the Long Eighteenth Century (Washington: Dumbarton Oaks Research Library and Collection Washington D.C, 2016).

Bayly, C. A., Empire and Information: Intelligence gathering and social communication in India, 1780-1870 (Cambridge: Cambridge University Press, 1996).

Beattie, James, Empire and Environmental Anxiety: Health, Science, Art and Conservation in South Asia and Australasia (Basingstoke: Palgrave Macmillan, 2011).

----'Thomas McDonnell's Opium: Circulating Plants, Patronage and Power in Britain, China and New Zealand, 1830-50s' in Batsaki Yota, Sarah Burke Cahalan, and Anatole Tchikine (eds.), The Botany of Empire in the Long Eighteenth Century (Washington, D.C: Dumbarton Oaks Research Library and Collection, 2016), pp.163-188.

Beekman, E. M., Fugitive Dreams: An Anthology of Dutch Colonial Literature (Amherst: University of Massachusetts Press, 1988).

Bennett, Brett M., 'Environmental Conservation and Deforestation in India 1855-1947: A Reconsideration', Itinerario: International Journal of the History of European Expansion and Global Interaction, Vol.38, no.2, 2008, pp. 83-104.

Bentley, Jerry H., Sanjay Subrahmanyam and Merry E. Weisner-Hanks (eds.), The Construction of a Global World, 1400-1800 CE Vol. VI, Part II: Patterns of Change (Cambridge: Cambridge University Press, 2015).

----The Construction of a Global World, 1400-1800 CE Vol. VI, Part I: Foundations (Cambridge: Cambridge University Press, 2015). 
Berkel, Klaas van, 'Een onwillige Mecenas', in J Bethlehem and A.C. Meijer (eds.), VOC en Cultuur: Wetenschappelijkeen Culturele Relatiestussen Europa en Azie ten tijde van de Verenigde Oostindische Compagnie (Amsterdam: Schiphouwer \& Brinkman,1993), pp. 39-58.

Bleichmar, Daniela, Visible Empire: Botanical Expeditions and Visual Culture in the Hispanic Enlightenment (Chicago: The University of Chicago Press, 2002).

---- 'Seeing the World in a Room: Looking at Exotica in Early Modern Collections' in Daniela Bleichmar and Peter C. Marshall (eds.) Collecting Across Cultures (Pennsylvania: University of Pennsylvania Press, 2011), pp. 15-30.

Blusse, Leonard and Ilonka Ooms (eds.), Kennis en Compagnie: De Verenigde Oost-Indische Compagnie en de modern Wetenschap (Amsterdam: Balans, 2002).

Boomgaard, Peter, F. Colombijn and David Henley (eds.), Paper Landscapes: Explorations in the Environmental History of Indonesia (Leiden: KITLV Press, 1988).

----Southeast Asia: An Environmental History (Santa Barbara: ABC-CLIO, 2007).

Boxer, C. R., The Portuguese Seaborne Empire 1415-1825(New York: A. A. Knopf, 1969).

----The Dutch Seaborne Empire 1600-1800 (London: Penguin, 1990 Reprint).

Binny, Malavika, 'Plants, Power and Knowledge: An Exploration of the Imperial Networks and the Circuits of Botanical Knowledge and Medical Systems on the Western Coast of India Against the backdrop of European Expansionism', Global Histories, Vol. 1, 2015, pp. 1-19.

Buissert, David, Mapmakers' Quest: Depicting New Worlds in Renaissance Europe (Oxford: Oxford University Press, 2003).

Chakrabarti, Pratik, Materials and Medicine: Trade, Conquest and Therapeutics in the Eighteenth Century (Manchester and New York: Manchester University Press, 2010).

----Medicine and Empire, 1600-1960 (London: Palgrave Macmillan, 2014).

Chambers, David Wade and Richard Gillespie, 'Locality in the History of Science: Colonial Science, Techno science, and Indigenous Knowledge', Osiris, Vol. 15, Nature and Empire: Science and the Colonial Enterprise, 2000, pp. 221-240.

Chandran, M.D., Subash, 'On the ecological history of the Western Ghats', Current Science, Vol. 73, no. 2, Special Section: Biodiversity of Western Ghats, 25 July 1997, pp. 146-155.

Cleetus, Burton, 'Subaltern Medicine and Social Mobility: The experience of the Ezhava in Kerala', Indian Anthropologist, Vol. 37, no. 1, 2007, pp.147-172.

Clulow, Adam and Tristan Mostert (eds.), The Dutch and English East India Companies: Diplomacy, Trade and Violence in Early Modern Asia (Amsterdam: Amsterdam University Press, 2018). 
Clunas, Craig, Superfluous Things: Material Culture and Social Status in Early Modern China (Oxford: Polity Press, 1991).

Cook, Harold, 'Natural History and Seventeenth Century Dutch and English medicine' in Hilary Marland and Margaret Pelling (eds.), The Task of Healing, Medicine, Religion and Gender in England and Netherlands, 1450-1800 (Rotterdam: Erasmus Publications, 1996), pp.253-257.

----Matters of Exchange: Commerce, Medicine and Science in the Dutch Golden Age (New Haven and London: Yale University Press, 2007).

Cooper, Alix, Inventing the Indigenous: Local Knowledge and Natural History in Early Modern Europe (Cambridge: Cambridge University Press, 2007).

Corrigan, Karina H., Jan van Campen, Femke Diercks and Janet. C Blyberg (eds.), Asia in Amsterdam: The Culture of Luxury in the Golden Age (London and New Haven: Yale University Press, 2015).

Cross, W. Redmond, 'Dutch Cartographers of the Seventeenth Century', Geographical Review, Vol. 6, no. 1, 1918, pp. 66-70.

Damodaran, Vinita, Anna Winterbottom and Alan Lester (eds.), The East India Company and the Natural World (London: Palgrave Macmillan, 2015).

Das Gupta, Ashin, Malabar in Asian Trade: 1740-1800 (London and New York: Cambridge University Press, 1967).

Daston, Lorraine and Katharine Park (eds.), Wonders and the Order of Nature, 1150-1750 (New York: Zone Books, 1998).

Daston, Lorraine, 'The History of Science and the History of Knowledge', KNOW: A Journal on the Formation of Knowledge, Vol. 1, No. 1, 2017, p. 146.

Davies, Surekha, Renaissance ethnography and the invention of the human: new worlds, maps and monsters (Cambridge: Cambridge University Press, 2016).

Desmond, Ray, Great Natural History Books and their Creators (London: British Library and Oak Knoll Press, 2003).

Dijksterhuis, Fokko Jan, Andreas Weber and Huib J. Zuidervaart (eds.), Locations of Knowledge in Dutch Contexts (Leiden and Boston: Brill, 2019).

Dijksterhuis, Fokko Jan, 'Duytsche Mathematique and the Building of a New Society: Pursuits of Mathematics in the Seventeenth-Century Dutch Republic' in Cormack L., Walton S., Schuster J. (eds.), Mathematical Practitioners and the Transformation of Natural Knowledge in Early Modern Europe. Studies in History and Philosophy of Science, Vol. 45 (Cham, Switzerland: Springer, 2017), pp. 167-181.

Dove, Michael. R., 'The Political Ecology of Pepper in the Hikayat Banjar: The historiography of Commodity Production in a Bornean kingdom' in Peter Boomgaard, F. Colombijn and David 
Henley(eds.), Paper Landscapes: Explorations in the Environmental History of Indonesia (Leiden: KITLV Press, 1998).

Drayton, Richard, Nature's Government: Science, Imperial Britain and the 'Improvement' of the World (Yale: Yale University Press, 2000).

----'Knowledge and Empire' in P. J. Marshall and Alaine Low (eds.), The Oxford History of the British Empire Vol II: The Eighteenth Century (New York: Oxford University Press, 1988).

Edney, Matthew H., Mapping an Empire: Geographical Construction of British India (Chicago and London: The University of Chicago Press, 1997).

---- Mary Sponberg Pedley and et.al (eds.), The History of Cartography, Vol. 4 (Chicago and London: The University of Chicago Press, 2020).

Endersby, Jim, “'From Having no Herbarium.” Local Knowledge versus Metropolitan Expertise: Joseph Hooker's Australasian Correspondence with William Colenso and Ronald Gunn', Pacific Science, Vol. 55, no. 4, 2001, pp.343-358.

Findlen, Paula, 'Anatomy Theaters, Botanical Gardens, and Natural History Collections' in Katherine Park \& Lorraine Daston (eds.), The Cambridge History of Science, Volume 3: Early Modern Science (Cambridge: Cambridge University Press, 2006), pp. 272-289.

Fleisher, Alette, 'The Company's Garden and the Exchange of Nature and Knowledge at Cape of Good Hope (1652-1700)' in Lissa Roberts (ed.) Centres and Cycles of Accumulation in and around the Netherlands (Muenster: LIT Verlag, 2011), pp. 101- 128.

Fraser, Kevin J., 'John Hill and the Royal Society in the eighteenth century', Royal Society of London, Vol. 48, no.1, 1994, pp. 43-67.

Frediani, Kevin, 'De Hortus Botanicus Amsterdam: Developing Themes in an Established Collection', The Journal of Botanic Garden Horticulture, Vol. 7, 2009, pp. 121-138.

Friedrich, Susanne, Arndt Brendecke, Stefan Ehrenpreis (eds.), Transformations of Knowledge in Dutch Expansion (Berlin and Boston: Walter de Gruyter, 2015).

Gaastra, Femme S., 'The Dutch East India Company: A Reluctant Discoverer', The Great Circle, Vol.19, no. 2, 1997, pp. 109-123.

----The Dutch East India Company: Expansion and Decline (Zutphen: Walburg Pers, 2003).

---- 'The organization of the VOC' in G. L Balk, F. van Dijk and D. J. Kortlang (eds.), The Archives of the Dutch East India Company (VOC) and the Local Institutions in Batavia (Jakarta) (Leiden and Boston: Brill, 2007), pp.13-60.

Gadgil Madhav and Ramachandra Guha (eds.), This Fissured Land: An Ecological History of India (New Delhi: Oxford University Press, 1992). 
Ganesh, K. N., 'Ownership and control of land in medieval Kerala: Janman-kanam relations during the $16^{\text {th }}-18^{\text {th }}$ centuries', The Indian Economic and Social History Review, Vol. 3, no. 3, 1991, pp.299-321.

Gelders, Raf, 'Genealogy of Colonial Discourse: Hindu Traditions and the Limits of European Representation', Comparative Studies in Society and History, Vol. 51, no. 3, 2009, pp. 563-589.

Goldgar, Anne, Tulipmania: Money, Honor and Knowledge in the Dutch Golden Age (Chicago and London: University of Chicago Press, 2007).

Greenblatt, Stephen, Marvelous Possessions: The Wonder of the New World (Chicago: The University of Chicago Press, 1991).

Grove, Richard, Green Imperialism: Colonial Expansion, Tropical Island Edens and the Origins of Environmentalism, 1600-1860 (Cambridge: Cambridge University Press, 1995).

----'Indigenous Knowledge and the Significance of South-West India for Portuguese and Dutch Constructions of Tropical Nature', Modern Asian Studies, Vol. 30, no. 1, 1996, pp. 121-143.

Gruzinski, Serge, 'Colonial Indian Maps in Sixteenth Century Mexico: An Essay in Mixed Cartography', RES: Anthropology and Aesthetics, no. 13, 1987, pp. 46-61.

Guha, Ramachandra, The Unquiet Woods: Ecological Change and Peasant Resistance in the Himalaya (Berkley: University of California Press, 1990).

Habib, Irfan, 'The eighteenth century in Indian economic history' in P. J. Marshall (ed.), The Eighteenth Century in Indian History (Cambridge: Cambridge University Press, 1997), pp. 358-378.

----'Cartography in Mughal India', Proceedings of the Indian History Congress, Vol. 35, 1974, pp.150162.

Harkness, Deborah E., The Jewel House: Elizabethan London and the Scientific Revolution (Yale: Yale University Press, 2007).

Harris, Steven J., 'Long-distance corporations, big sciences, and the geography of knowledge' in Sandra G. Harding (ed.), The Postcolonial Science and Technology Studies Reader (Duke: Duke University Press, 2011), pp. 61-83.

Heninger, J., 'Some Botanical Activities of Herman Boerhave, Professor of Botany and Director of the Botanic Garden at Leiden', Janus, Vol. 58, no. I, 1971, pp. 1-78.

----Hendrik Adriaan van Reede tot Drakenstein (1636-1691) and Hortus Malabaricus: A Contribution to the History of Dutch Colonial Botany (Rotterdam, Boston: A. A. Balkema, 1986).

Horst, Marleen H. J., Compensation for Improvements: The Roman Dutch Law in Sri Lanka (Amsterdam: Free University Press, 1989).

Huigen, Siegfried, Jan L. de Jong and Elmer Kolfin (eds.), The Dutch Trading Companies as Knowledge Networks (Leiden: Brill, 2010). 
Israel, Jonathan Irvine, Dutch Primacy in World Trade, 1585-1740 (Oxford: Clarendon Press, 1989).

----The Dutch Republic: Its Rise, Greatness and Fall, 1477-1806 (Oxford: Clarendon Press, 1995).

Jacob, Hugo K. s', Nederlanders in Kerala, 1663-1701: Memories and instructions concerning the Malabar command of the Dutch East India Company (s' Gravenhage: Martinus Nijhoff, 1976).

----The Rajas of Cochin 1663-1720: Kings, Chiefs and the Dutch East India Company (New Delhi: Munshiram Manoharlal, 2000).

---- 'De VOC en de Malabarkust in de 17eeuw', in M. A. P. Meilink- Roelofsz (ed.), De VOC in Azië(Bussum: Fibula-Van Dishoeck, 1976)

Joseph, Sebastian, Cochin Forests and the Techno-Ecological Imperialism in India (New Delhi: Primus Books, 2016).

Kagan, Richard L. and Benjamin Schmidt, 'Maps and the Early Modern State: Official Cartography' in David Woodward (ed.), History of Cartography, Vol. III: Cartography in the European Renaissance (Chicago and London: The University of Chicago Press, 2007), pp.661-679.

Kapil, R. N. and A. K. Bhatnagar, 'Portuguese Contributions to Indian Botany', Isis, Vol. 67, no. 3, September 1976, pp.449-452.

Keller, Vera, Knowledge and the Public Interest, 1575-1725 (Cambridge: Cambridge University Press, 2015).

Kian, Kwee Hui, 'How Strangers Became Kings: Javanese-Dutch relations in Java 1600-1800', Indonesia and the Malay World, Vol. 36, no. 105, 2008, pp. 293-307.

Kieniewicz, Jan, 'Asian Merchants and European Expansion: Malabar Pepper Trade Routes in the Indian Ocean World-System in the Sixteenth Century' in K. R. Haellquist (ed.), Asian Trade and Routes, Continental and Maritime (London: Curzon Press, 1991).

Kooijmans, L., Death Defied: The Anatomy Lessons of Frederik Ruysch (Leiden and Boston: Brill Publishers, 2010).

Kooria, Mahmood, Patappattu, a Malayalam War-Song on the Portuguese Dutch Battle in Cochin' in Mahmood Kooria and Michael Pearson (eds.), Malabar in the Indian Ocean: Cosmopolitanism in a Maritime Historical Region (New Delhi: Oxford University Press, 2018), pp.141-171.

Koshy, M. O., The Dutch Power in Kerala (1729-1758) (New Delhi: Mittal Publications, 1989).

Kumar, Deepak, 'Developing a History of Science and Technology in South Asia', Economic and Political Weekly, Vol. 38, no. 23, 2003, pp. 2248-2251.

Kuys, J. and J. T. Schoenmakers, Landpachten in Holland, 1500-1650 (Amsterdam: Historisch Seminarium van de Universiteit van Amsterdam, 1981), 
Lach, Donald F., Asia in the Making of Europe: The Century of Discovery, Vol. 1, Book 1 (Chicago: University of Chicago, 1965).

Latour, Bruno, Science in Action: How to follow scientists and engineers through Society (Cambridge and Massachusetts: Harvard University Press, 1987).

Liebenberg, Elri, 'Unveiling the Geography of the Cape of Good Hope: Selected VOC Maps of the Interior of South Africa' in E. Liebenberg and I.J Demhardt, (eds.), History of Cartography: Lectures notes in Geoinformation and Cartography (Berlin and Heidelberg: Springer-Verlag, 2012), pp. 209-232.

Leitch, Stephanie, 'Burgkmair's Peoples of Africa and India (1508) and the Origins of Ethnography in Print', The Art Bulletin, Vol. 91, no. 2, 2009, pp. 134-159.

Livingstone, David N., Putting Science in its Place: Geographies of Scientific Knowledge (Chicago and London: The University of Chicago Press, 2003).

Loudon, John Claudius, An Encyclopaedia of Gardening Comprising the Theory and Practice (London: Spottiswoode, 1835).

Lloyd, G. E. R., 'Introduction', in G.E.R Llyod (eds. and intro), J. Chadwick and W.N. Mann (trans.), Hippocratic Writings (London: Penguin, 1983 Reprint).

Mabberley, D.J. and Francis Hamilton, 'Francis Hamilton's Commentaries with Particular Reference to Melianceae', Taxon, Vol. 26, no. 5/6, Nov. 1977, pp. 523-540.

Mailaparambil, Binu J., Lords of the Sea: The Ali Rajas of Cannanore and the Political Economy of Malabar (1663-1723) (Leiden: Brill, 2012).

Malekandathil, Pius, Portuguese Cochin and the Maritime Trade of India 1500-1663 (New Delhi: Manohar, 2001).

----'Winds of Change and Links of Continuity: A study on the Merchant Groups of Kerala and the Channels of their Trade, 1000-1800', Journal of the Economic and Social History of the Orient Vol. 50, 2007, pp. 259-286.

---'Changing Perceptions of Sea and the Shaping of Urban Space in Medieval Kerala', in K. Madavane (ed.), Histories from the Sea: Proceedings of International Conference 30-31 January 2007 (New Delhi: Jawaharlal Nehru University, 2009), pp.50-67.

----'Coastal Polity and Changing Port Hierarchy of Kerala' in Yogesh Sharma (ed.), Coastal Histories: Society and Ecology in Pre-modern India (New Delhi: Primus Books, 2010), pp.75-90.

Manilal, K. S., Botany and the History of Hortus Malabaricus (Rotterdam and Oxford: A. A. Balkema and Oxford IBH, 1980). 
Margócsy, Dániel, Commercial Visions: Science, Trade and Visual Culture in the Dutch Golden Age (Chicago and London: The University of Chicago Press, 2014).

Mathew, K. S., Portuguese Trade with India in the Sixteenth Century (New Delhi: Manohar, 1983).

Mbeki, Linda and Matthias van Rossum, 'Private slave trade in the Dutch Indian Ocean world: a study into the networks and backgrounds of the slavers and the enslaved in South Asia and South Africa', Slavery and Abolition, Vol. 38, no. 1, 2017, pp.95-116.

Menon, Sreedharan, A Survey of Kerala History (Kottayam: Sahitya Pravarthaka Co-operative Society Ltd., 1967).

Minson, Marion, Encounter with Eden - New Zealand 1770 - 1870: paintings \& drawings from the Rex Nan Kivell Collection, National Library of Australia (Wellington: National Library of New Zealand, 1990),

Mitter, Partha, Much Maligned Monsters: History of European Reactions to Indian Art (Oxford: Clarendon Press, 1977).

Morgan, Ruth A., 'Histories for an Uncertain Future: Environmental History and Climate Change', Australian Historical Studies Vol. 44, no.3, 2013, pp. 350-360.

Morrison, Kathleen. D., 'Environmental History, Spice Trade, and the State in South India' in Mahesh Rangarajan and K. Sivaramakrishnan (eds.), India's Environmental History: from Ancient Times to the Colonial Period (New Delhi: Permanent Black, 2012), pp.43-64.

Mukherji, Chandra, Impossible engineering: technology and territoriality on the Canal du Midi (Princeton: Princeton University Press, 2009).

Needham, Joseph, Science and Civilization in China, Vol. III (Cambridge: Cambridge University Press, 1995 Reprint).

Novak, Maximillian E., ed. The Age of Projects (Toronto: University of Toronto Press, 2008).

Ogilvie, Brian W., The Science of Describing (Chicago and London: University of Chicago Press, 2006).

Panikkar, K.M., Malabar and the Portuguese: Being a History of the Relations of the Portuguese with Malabar from 1500 to 1663 (Bombay: Taraporevala sons and Company, 1929).

----Malabar and the Dutch (Bombay: D.B. Taraporevala Sons and Co., 1931).

Parthesius, Robert, Dutch Ships in Tropical Waters: The Development of the Dutch East India Company (VOC) and Shipping Network in Asia 1595-1660 (Amsterdam: Amsterdam University Press, 2010).

Pearson, Michael N., The Portuguese in India (Cambridge: Cambridge University Press, 1987).

----Spices in the Indian Ocean World (London: Ashgate Publishing, 1996.) 
----The Indian Ocean (London: Routledge, 2003).

Pillai, Manu S., The Ivory Throne: Chronicles of the House of Travancore (Noida: Harper Collins, 2016).

Prakash, Om, 'International Consortiums, Merchant Networks and Portuguese Trade with Asia in the Early Modern Period', Paper presented at Session 37 of the Fourteenth International Economic History Congress, 21-25 August, Helsinki, 2006.

Prange, Sebastian, “Measuring by the Bushel”: Reweighing the Indian Ocean pepper trade', Historical Research, Vol. 84, Issue no. 224, 2011, pp.212-235.

----Monsoon Islam: Trade and Faith on the Medieval Malabar Coast (Cambridge: Cambridge University Press, 2018).

Pratt, Mary Louis, Imperial Eyes: Travel Writing and Transculturation (London and New York: Routledge, 1992).

Protschky, Susie, Images of the tropics: Environment and visual culture in colonial Indonesia (Leiden, KITLV Press, 2011),

Raina, Dhruv and Irfan S Habib, Domesticating Modern Science: A Social History of Science and Culture in Colonial India (New Delhi: Tulika Books, 2004).

Raj, Kapil, "18th-Century pacific voyages of discovery, "big science", and the shaping of a European scientific and technological culture,' History and Technology, an International Journal, Vol. 17, no. 2, 2000, pp. 79-98.

----Relocating Modern Science: Circulation and the Construction of Knowledge in South Asia and Europe, 1650 1900 (London: Palgrave Macmillan, 2007).

----'Thinking Without the Scientific Revolution: Global Interactions and the Construction of Knowledge', Journal of Early Modern History, Vol. 21, 2017, pp. 445-458.

----'Ethnolinguistics and Cartography in Early Colonial India: Spaces of Circulation and Empires of Knowledge' in Paula Findlen (ed.), Empire of Knowledge: Scientific Networks in the Early Modern World (Oxford: Routledge, 2018), pp. 264-294.

----'Networks of knowledge, or spaces of circulation? The birth of British cartography in colonial South Asia in the late eighteenth century', Global Intellectual History Vol. 2, no. 1, 2017, pp.49-66.

Rajendran, N., 'Background of the Mysorean Invasion of Malabar 1765-66', Proceedings of the Indian History Congress, Vol. 39, no. II, 1978, pp.613-617.

Sita Reddy, 'Hortus Indicus Malabaricus' in Marg: The Weight of a Petal: Ars Botanica, Vol.70, no. 2, 2018, pp.58-63.

Reid, Anthony, Southeast Asia in the Age of Commerce, 1450-1680, Volume 2, Expansion and Crisis (Yale: Yale University Press, 1995). 
Reitbergen, P.J., A short history of the Netherlands (Amersfoort: Vanderheide Publishing Co., 2004).

Robertson, Jeffrey and Warwick Funnell (eds.), Accounting by the First Public Company: The Pursuit of Supremacy (New York and London: Routledge, 2014).

Sargent, Matthew, 'Recentering centers of calculation: Reconfiguring knowledge networks within global empires of trade' in Paula Findlen (ed.), Empires of Knowledge: Scientific Networks in the Early Modern World (Oxford: Routledge, 2018), pp.297-316.

Schama, Simon, The Embarrassment of Riches: An Interpretation of Dutch culture in the Golden Age (New York: Vintage Books, 1997).

Schiebinger, Londa, Plants and Empire: Colonial Bioprospecting in the Atlantic World (Cambridge, Massachusetts: Harvard University Press, 2004).

---- and Claudia Swan, Colonial Botany: Science, Commerce and Politics in the Early Modern World (Philadelphia: University of Pennsylvania Press, 2005).

----'Forum Introduction: The European Colonial Science Complex,' Isis, Vol. 96, 2005, pp.52-55.

Schmidt, Benjamin, 'Mapping an Empire: Cartographic and Colonial Rivalry in SeventeenthCentury Dutch and English North America', The William and Mary Quarterly, Vol. 54. no. 3, 1997, pp.549-578.

----Inventing Exoticism: Geography, Globalism, and Europe's Early Modern World (Philadelphia: University of Pennsylvania, 2015).

Schrikker, Alicia, F, Dutch and British colonial intervention in Sri Lanka c. 1780 - 1815: Expansion and Reform (Leiden and Boston: Brill, 2007).

Shapin, Steven, 'Pump and Circumstance: Robert Boyle's Literary Technology', Social Studies of Science, Vol. 14, no. 4, 1984, pp. 481-520.

Singh, Anjana, Fort Cochin in Kerala, 1750-1830: The Social Condition of a Dutch Community in an Indian Milieu (Leiden: Brill, 2010).

Sivasundaram, Sujit, 'Tales of the Land: British Geography and Kandyan Resistance in Sri Lanka, c. 1803-1850, Modern Asian Studies, Vol. 41, no. 5, 2007, pp. 925-965.

Smith, Pamela H. and Paula Findlen (eds.), Merchants and Marvels: Commerce, Science and Art in Early Modern Europe (London and New York: Routledge, 2002).

---- 'Art, Science and Visual Culture in Early Modern Europe', Isis, Vol. 97, no. 1, 2006, pp. 83100.

----'A Tulip for a Cup of Tea? Commerce and Nature in the Dutch Golden Age', Annals of Science, Vol. 66, no. 2, 2009, pp. 267-276. 
----The Body of the Artisan: Art and Experience in the Scientific Revolution (Chicago: The University of Chicago Press, 2012).

Spencer, Roger and Rob Cross, 'The origins of botanic gardens and their relation to plant science, with special reference to horticultural botany and cultivated plant taxonomy', Muelleria Vol. 35, 2017, pp. 43-93.

Star, Susan Leigh and James R. Griesemer, 'Institutional Ecology, "Translations" and Boundary Objects: Amateurs and Professionals in Berkeley's Museum of Vertebrate Zoology, 1907-39', Social Studies of Science, Vol. 19, no. 3, 1989, pp.387-420.

----'The Structure of Ill-Structured Solutions: Boundary Objects and Heterogeneous Distributed Problem Solving', in L. Gasser and N. Huhns (eds.), Distributed Artificial Intelligence (New York: Morgan Kauffman Publications, 1989), pp. 37-54.

Stoler, Ann Laura, Along the Archival Grain: Epistemic Anxieties and Colonial Common Sense (Princeton: Princeton University Press, 2008).

Subrahmanyam, Sanjay and Christopher Bayly, 'Portfolio Capitalists and Political Economy of Early Modern India', The Indian Economic and Social History Review, Vol. 25, 1988. pp. 243-265.

----and Luis Filipe F.R. Thomaz, 'Evolution of Empire: The Portuguese in the Indian Ocean During the Sixteenth Century' in James D. Tracy (ed.), Political Economy of Merchant Empires: State Power and World Trade 1350-1750 (Cambridge: Cambridge University Press, 1991), pp.298-331.

----'Between a Rock and a Hard Place: Some Afterthoughts' in Kapil Raj, Simon Schaffer, Lissa Roberts and James Delbourgo (eds.), The Brokered World: Go-Betweens and Global Intelligence, 17701820 (Sagamore Beach: Science History Publications, 2009), pp.429-440.

----'A Roomful of Mirrors: The Artful Embrace of Mughals and Franks, 1550-1700', Ars Orientalis, Vol. 39, 2010, pp.39-83.

Sutton, Elizabeth, 'Mapping Dutch Nationalism across the Atlantic', Artl@s Bulletin, Vol.2, no. 1, 2013, pp. 6-13.

----Capitalism and Cartography in the Dutch Golden Age (London and Chicago: The University of Chicago Press, 2015).

Swan, Claudia, 'Medical Culture at Leiden University ca. 1600: A Social History in Prints' Nederlands Kunsthistorisch Jaarboek, Vol. 52, 2002, pp. 217-239.

----'Collecting Naturalia in the Shadows of Early Modern Dutch Trade' in Londa Schiebinger and Claudia Swan (eds.), Colonial Botany: Science, Commerce and Politics in the Early Modern World (Philadelphia: University of Pennsylvania Press, 2005), pp.223-236.

----'Lost in Translation: Exoticism in Early Modern Holland' in A. Langer (ed.), Art in Iran and Europe in the 17th Century: Exchange and Reception (Zurich: Museum Rietberg, 2013), pp.100-116. 
Tosi, Alessandro, 'Botanical Illustration and the idea of the Garden in the Sixteenth Century between Imitation and Imagination' in Hubertus Fischer, Volker R. Remmert and Joachim Wolschke-Bulmahn (eds.) Gardens, Knowledge and the Science in the Early Modern Period (Switzerland: Birkhauser, 2016), pp.183-210.

Turnbull, David, 'Cartography and Science in Early Modern Europe: Mapping the Construction of Knowledge Spaces’, Imago Mundi, Vol. 48, 1996, pp. 5-24.

----Masons, Tricksters and Cartographers: Comparative Studies in the Sociology of Scientific and Indigenous Knowledge (London: CRC Press LLC, 2000).

Varrier, M. R Raghava, 'Swarupam as state: An Introductory Essay' in R. Champakalakshmi et al. (eds.) State and Society in Pre-modern South India (Thrissur: Cosmo books, 2002), pp.120-130.

Vink, Marcus P.M., Encounters on the Opposite Coast: The Dutch East India Company and the Nayaka State of Madurai in the Seventeenth Century (Leiden and Boston: Brill, 2015).

Ward, Kerry, Networks of Empire: Forced Migration in the Dutch East India Company (Cambridge: Cambridge University Press, 2008).

Wijnards, Dirk Onno, The Botany of the Commelins (Rotterdam: A. A. Balkema, 1983).

Williams, Rojer L., Botanophillia in Eighteenth-Century France: The Spirit of the Enlightenment (Dordrecht and Boston: Kluwer Academic Publishers, 2001).

Winichakul, Thongchai, Siam Mapped: A History of the Geo-Body of a Nation (Honolulu: University of Hawaii Press, 1994).

Winius, George D. and Marcus P. M. Vink (eds.), The Merchant-Warrior Pacified: The Dutch East India Company and its Changing Political Economy in India (Delhi: Oxford University Press, 1994).

Winterbottom, Anna, 'From Hold to Foredeck: Slave Professions in the Maritime World of the East India Company, c. 1660-1720' in Fusaro, Maria and Amélia Polónia, (eds.), Maritime History as Global History (Liverpool: Liverpool University Press, 2010), pp.95-124.

----Hybrid Knowledge in the Early East India Company World (Cambridge and New York: Palgrave Macmillan, 2015).

----'Science' in William A. Pettigrew and David Veevers (eds.), The Corporation as a Protagonist in Global History, c. 1550-1750 (Leiden and Boston: Brill, 2019), pp.232-254.

Zandvliet, Kees V., 'The Contribution of Cartography to the Creation of Dutch Colony and a Chinese State in Taiwan', Cartographica, Vol. 35, no.3-4, 1998, pp.123-135.

----Mapping for Money: Maps, Plans, and Topographic Paintings and Their Role in Dutch Overseas Expansion During the 16th and 17th Centuries (Amsterdam: Batavian Lion International, 1998). 
----'Mapping the Dutch World Overseas in the Seventeenth Century' in David Woodward (ed.), History of Cartography (Chicago and London: The University of Chicago Press, 2007), pp. 14331462.

Zupanov, Ines G., 'Amateur Naturalist and "Professional" Orientalist; Paulinus S. Bartholomaeo in Kerala and Rome (18th-19th c.)', Review of Culture, no. 20, 2006, pp.77-101.

----and Ângela Barreto Xavier, "Quest for Permanence in the Tropics: Portuguese Bio prospecting in Asia (16th18th Centuries)", Journal of the Economic and Social History of the Orient, Vol.57, 2014, p.511-548.

\section{PhD Theses}

Kuruppath, Manjusha, 'Staging Asia: The Dutch East India Company and the Amsterdam Theatre', PhD Thesis, Leiden University, 2016.

Stijnman, Adrianus Cornelis Jacobus, 'A History of Engraving and Etching Techniques: Developments of Manual Intaglio Printmaking Processes, 1400-2000', PhD Thesis, University of Amsterdam, 2012.

Zwart, Pim de., 'Globalization and the Colonial Origins of the Great Divergence: Intercontinental Trade and Living Standards in the Dutch East India Company's Commercial Empire, c. 16001800', PhD Thesis, Utrecht University, 2015.

\section{Websites}

A historic Dutch visit to Kollat house; https://hortusmalabaricus.net/historic-dutch-visit-kollathouse; accessed 25 April 2020.

A new Hortus Malaabricus - Garden of Malabar; https://hortusmalabaricus.net/new-hortusmalabaricusgarden-malabar; accessed 26 April 2020

http://verapolyheritage.org/legacies/ accessed 12/05/19 
